\title{
Copper-Catalyzed Asymmetric Reductions of Aryl/Heteroaryl Ketones under Mild Aqueous Micellar Conditions
}

\author{
David M. Fialho, ${ }^{a}$ Elham Etemadi-Davan,, Olivia C. Langner, ${ }^{a}$ Balaram S. Takale, ${ }^{a}$ \\ Amol Gadakh, ${ }^{b}$ Ganesh Sambasivam, ${ }^{\mathrm{b}}$ and Bruce H. Lipshutz ${ }^{\mathrm{a}}$ \\ aDepartment of Chemistry \& Biochemistry, University of California, Santa Barbara, CA 93106 USA \\ ${ }^{\mathrm{b}}$ Anthem Biosciences Private Limited, Bommasandra Industrial Area, Phase-I, \\ Bommasandra, Bangalore - 560099 India
}

\section{Supporting Information}

1. General information ............................................................................................................

1.1. Surfactant solution preparation .....................................................................................

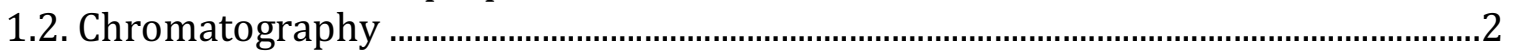

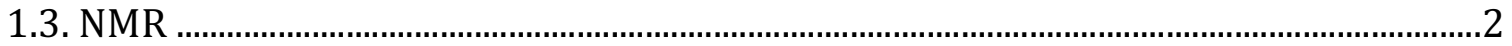

1.4. MS ……

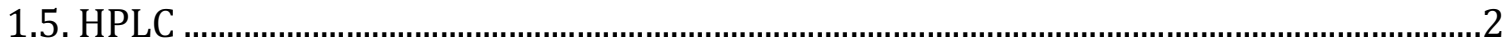

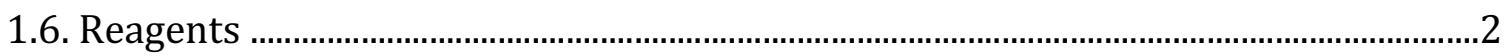

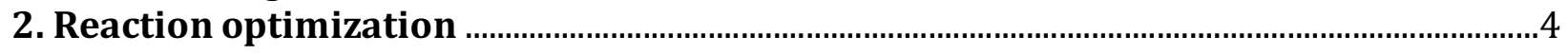

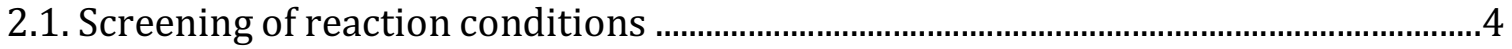

2.2. HPLC analysis of products from optimization trials .......................................................

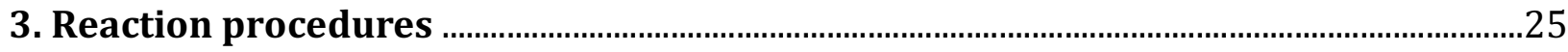

3.1. General procedures for the asymmetric reduction of aryl/heteroaryl ketones ....25

3.2. General procedure for the synthesis of racemic sec-alcohols standards .................26

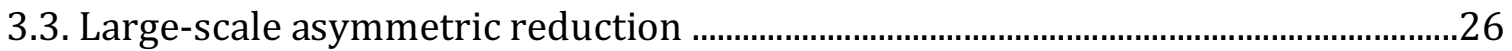

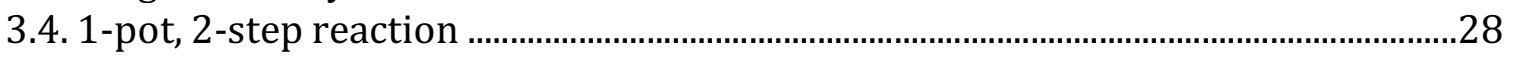

3.5. Medium/catalyst recycling study and EFactor calculation ..........................................31

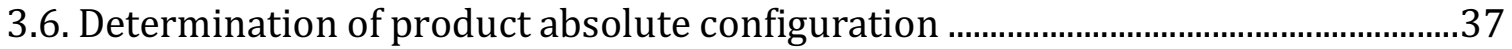

4. Synthesis and characterization of starting materials …....................................................40

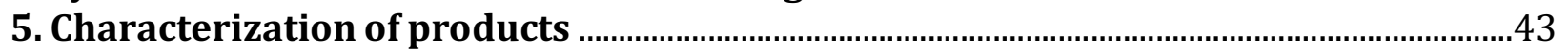

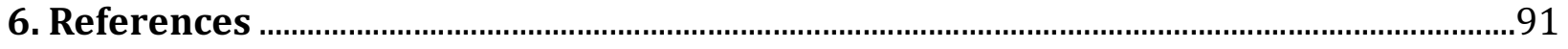

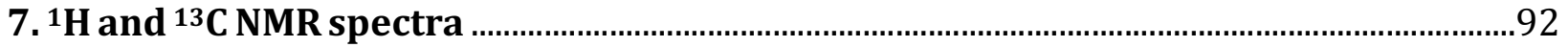




\section{General information}

\subsection{Surfactant solution preparation}

TPGS-750-M was obtained from Zhejiang Sancus-Arc Biochemical Technology Co., Ltd., or synthesized according to the reported literature. ${ }^{1} \mathrm{MC}-1$ was synthesized according to a literature procedure. ${ }^{2}$ Brij 35 (Brij L23) was purchased from MilliporeSigma (formerly Sigma-Aldrich). HPLC-grade water was obtained from Fischer Scientific and was purged with argon before use. The $2 \mathrm{wt} \%$ aqueous surfactant solutions were prepared by dissolving $2 \mathrm{~g}$ of surfactant solid in $98 \mathrm{~g}$ of HPLC-grade water. The solutions were stored under argon.

\subsection{Chromatography}

Thin layer chromatography (TLC) was performed using Silica Gel 60 F254 plates (Merck, $0.25 \mathrm{~mm}$ thick). Flash chromatography was performed either in glass columns or with a Biotage Isolera One purification instrument using Silica Gel 60 (EMD, 40-63 $\mu \mathrm{m}$ ).

\subsection{NMR}

${ }^{1} \mathrm{H}$ NMR and ${ }^{13} \mathrm{C}$ NMR were recorded on a Varian Unity Inova $\mathrm{MHz}$ instrument (600 $\mathrm{MHz}$ ${ }^{1} \mathrm{H} / 151 \mathrm{MHz}{ }^{13} \mathrm{C}, 500 \mathrm{MHz}{ }^{1} \mathrm{H} / 126 \mathrm{MHz}{ }^{13} \mathrm{C}$, or $400 \mathrm{MHz}{ }^{1} \mathrm{H} / 101 \mathrm{MHz}{ }^{13} \mathrm{C}$ ). Deuterated solvents were purchased from Cambridge Isotope Laboratories. Chemical shifts $(\delta)$ are reported in ppm and coupling constants () are reported in $\mathrm{Hz}$. Data are reported as follows: chemical shift, multiplicity ( $\mathrm{s}=$ singlet, $\mathrm{bs}=$ broad singlet, $\mathrm{d}=$ doublet, $\mathrm{bd}=$ broad doublet, $\mathrm{t}$ = triplet, $\mathrm{q}=$ quartet, quin = quintet, $\mathrm{m}=$ multiplet), coupling constant (if applicable), and integration value.

\subsection{MS}

HRMS analysis (ESI-MS or EI-MS) was performed by the UC Santa Barbara mass spectrometry facility. ESI-MS analysis was performed on a Waters LCT Premier mass spectrometer equipped with an Alliance 2695 Separations module. EI-MS analysis was performed on a Waters GCT Premier mass spectrometer equipped with an Agilent 7890A GC oven and J\&W Scientific DB-5ms+DG narrow bore column using helium carrier gas. ICP-MS analysis was performed on a PerkinElmer NexION 2000 instrument by the UC Los Angeles ICP-MS facility within the UC Center for Environmental Implications of Nanotechnology.

\subsection{HPLC}

HPLC analysis was performed on an Agilent 1220 series HPLC with columns indicated for each compound. HPLC-grade solvents were obtained from Fischer Scientific.

\subsection{Reagents}

Poly(methylhydrosiloxane) (PMHS, formula weight ca. 1900) was obtained from Alfa Aesar. Copper(II) acetate hydrate was obtained from MilliporeSigma (formerly Sigma-Aldrich). 
BIPHEP ligands used for initial ligand screening were gifted by Hoffmann La-Roche. $(R)$ 3,4,5-Me0-MeO-BIPHEP used for substrates was obtained from MilliporeSigma. (S)-3,4,5MeO-MeO-BIPHEP was obtained from Strem Chemicals. ( $R$ )-DTBM-SEGPHOS was gifted from Takasago. JosiPhos ligands (SL-J001-1 and SL-J011-1) were obtained from Solvias. All phosphine ligands were stored under argon. All other ketone substrates were obtained from, or synthesized from precursors obtained from, MilliporeSigma, Combi-Blocks, Alfa Aesar, or TCI, and were used as received. Organic solvents were dried with a solvent purification system from Innovative Technology, Inc., and used immediately after being dispensed. 


\section{Reaction optimization}

\subsection{Screening of reaction conditions}

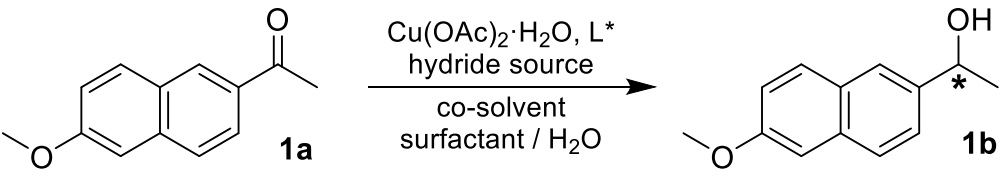

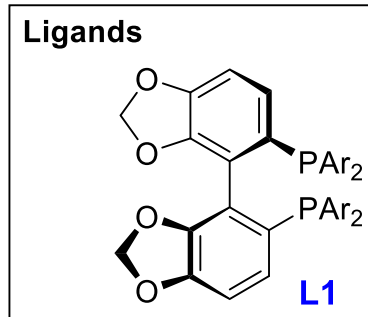

L1: $\mathrm{Ar}=3,5-{ }^{\mathrm{di}}{ }^{\mathrm{t}} \mathrm{Bu}-4-\mathrm{MeO}-$ phenyl [(R)-DTBM-SEGPHOS]

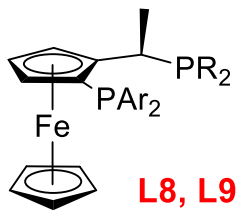

L8: $\mathrm{Ar}=\mathrm{Ph}, \mathrm{R}=$ cyclohexyl [JosiPhos SL-J001-1]

L9: $\mathrm{Ar}=4-\mathrm{CF}_{3}$-phenyl, $\mathrm{R}={ }^{\mathrm{t}} \mathrm{Bu}$ [JosiPhos SL-J011-1]<smiles>[R]c1cc([R16])c(-c2c(OC)cc([R])cc2OC)c([R16])c1</smiles>

L2 - L7
$\mathrm{L} 2: \mathrm{Ar}=\mathrm{Ph}$

$\mathrm{R}=\mathrm{H}$

[(R)-MeOBIPHEP]

L3: $\mathrm{Ar}=3,5-\mathrm{Xyl}$

$\mathrm{R}=\mathrm{H}$

[(R)-3,5-Xyl-MeO-BIPHEP]

L4: $\mathrm{Ar}=3,5$-di- ${ }^{\mathrm{t}} \mathrm{Bu}$-phenyl

$\mathrm{R}=\mathrm{H}$

[(R)-3,5-'Bu-MeO-BIPHEP]

L5: $\mathrm{Ar}=\mathrm{p}-\mathrm{Tol}$

$\mathrm{R}=\mathrm{MeO}$

[(R)-Tol-GarPhos]

L6: $\mathrm{Ar}=3,5$-di- ${ }^{\mathrm{t}} \mathrm{Bu}-4-\mathrm{MeO}-$ phenyl $\mathrm{R}=\mathrm{H}$

$[(R)$-DTBM-MeO-BIPHEP $]$

L7: $\mathrm{Ar}=3,4,5$-tri-MeO-phenyl

$\mathrm{R}=\mathrm{H}$

[(R)-3,4,5-MeO-MeO-BIPHEP]

\section{Surfactants}
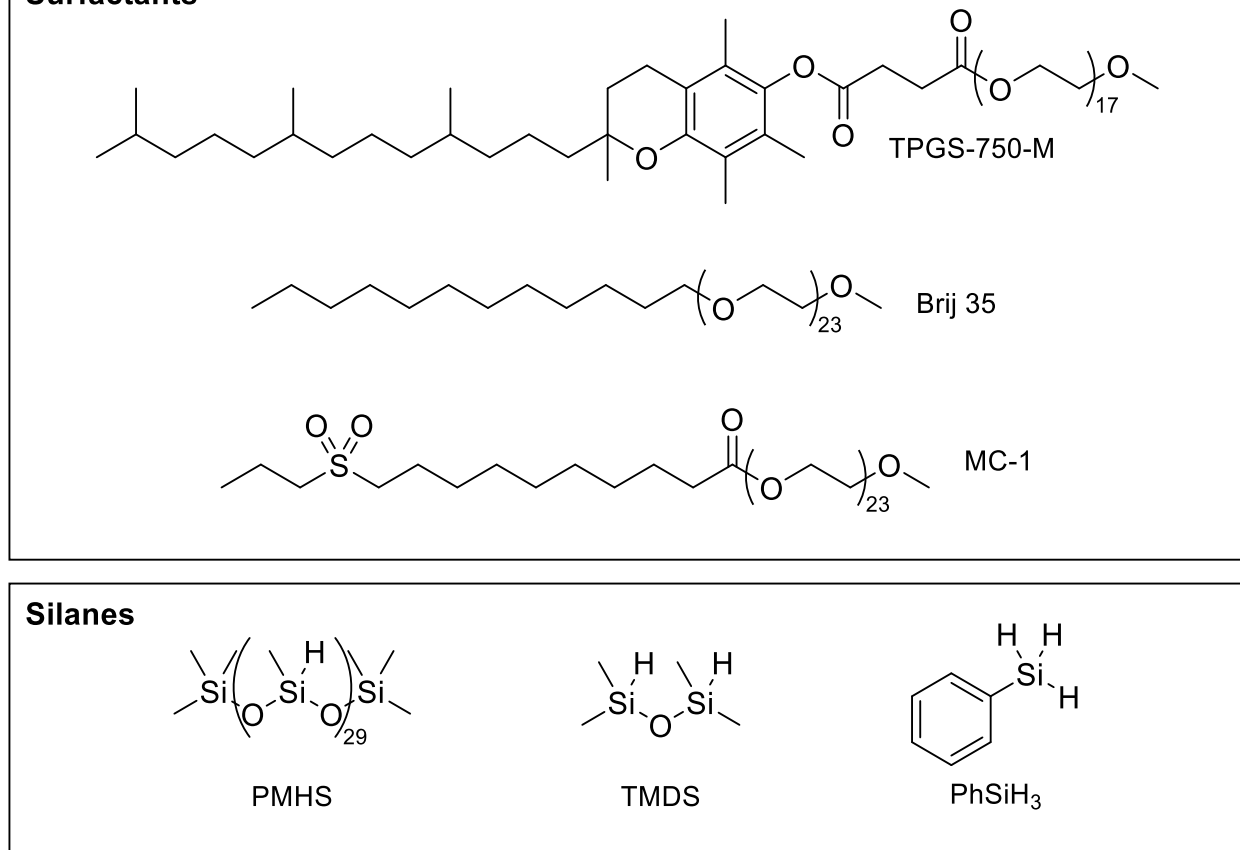

Figure S1. Structures of substrate (1a), product (1) ), ligands, surfactants, and silanes used in optimization of asymmetric ketone reduction in water. 
Table S1. Screening of Reaction Components for Asymmetric Ketone Reduction

\begin{tabular}{|c|c|c|c|c|c|c|c|c|}
\hline entry & ligand & surfactant & co-solvent & temp. & silane & additive & yield (\%) & ee (\%) \\
\hline $1^{\mathrm{a}, \mathrm{b}}$ & L1 & TPGS-750-M & THF & $22^{\circ} \mathrm{C}$ & PMHS & - & 18 & ND \\
\hline $2^{a, b}$ & $(S)-\mathbf{L} \mathbf{3}$ & TPGS-750-M & THF & $22^{\circ} \mathrm{C}$ & PMHS & - & 13 & ND \\
\hline $3 \mathrm{a}, \mathrm{b}$ & L8 & TPGS-750-M & THF & $22^{\circ} \mathrm{C}$ & PMHS & - & 0 & ND \\
\hline $4^{a, b}$ & L1 & Brij 35 & THF & $22^{\circ} \mathrm{C}$ & PMHS & - & 10 & ND \\
\hline $5^{\mathrm{a}, \mathrm{b}}$ & L1 & MC-1 & THF & $22^{\circ} \mathrm{C}$ & PMHS & - & 11 & ND \\
\hline $6 \mathrm{a}, \mathrm{b}$ & L1 & $\mathrm{H}_{2} \mathrm{O}$ & - & $22^{\circ} \mathrm{C}$ & PMHS & - & $<10$ & ND \\
\hline $7 \mathrm{a}, \mathrm{b}$ & L1 & TPGS-750-M & THF & $22^{\circ} \mathrm{C}$ & TMDS & - & $<10$ & ND \\
\hline $8 \mathrm{a}, \mathrm{b}$ & L1 & TPGS-750-M & THF & $22^{\circ} \mathrm{C}$ & $\mathrm{PhSiH}_{3}$ & - & $<10$ & ND \\
\hline $9 \mathrm{~b}$ & L7 & TPGS-750-M & THF & $22^{\circ} \mathrm{C}$ & PMHS & - & 65 & 93 \\
\hline 10 & L7 & TPGS-750-M & THF & $22^{\circ} \mathrm{C}$ & PMHS & - & 77 & 93 \\
\hline 11 & L7 & TPGS-750-M & THF & $22^{\circ} \mathrm{C}$ & PMHS & $\mathrm{Et}_{3} \mathrm{~N}$ & 58 & ND \\
\hline 12 & $(S)-\mathbf{L} 3$ & TPGS-750-M & THF & $22^{\circ} \mathrm{C}$ & PMHS & - & 60 & -84 \\
\hline 13 & L9 & TPGS-750-M & THF & $22^{\circ} \mathrm{C}$ & PMHS & - & 25 & 18 \\
\hline 14 & $(S)-\mathbf{L 3}$ & TPGS-750-M & THF & $22^{\circ} \mathrm{C}$ & PMHS & - & 78 & -79 \\
\hline 15 & L5 & TPGS-750-M & THF & $22^{\circ} \mathrm{C}$ & PMHS & - & 81 & 81 \\
\hline 16 & L6 & TPGS-750-M & THF & $22^{\circ} \mathrm{C}$ & PMHS & - & 78 & 87 \\
\hline 17 & $(S)-\mathbf{L} \mathbf{2}$ & TPGS-750-M & THF & $22^{\circ} \mathrm{C}$ & PMHS & - & 75 & -74 \\
\hline 18 & L4 & TPGS-750-M & THF & $22^{\circ} \mathrm{C}$ & PMHS & - & 80 & 87 \\
\hline 19 & L7 & TPGS-750-M & toluene & $22^{\circ} \mathrm{C}$ & PMHS & - & 83 & 95 \\
\hline $20 c$ & L7 & TPGS-750-M & toluene & $22^{\circ} \mathrm{C}$ & PMHS & - & 80 & 95 \\
\hline 21 & L7 & TPGS-750-M & $\mathrm{CH}_{3} \mathrm{CN}$ & $22^{\circ} \mathrm{C}$ & PMHS & - & 0 & ND \\
\hline 22 & L7 & TPGS-750-M & $\mathrm{MeOH}$ & $22^{\circ} \mathrm{C}$ & PMHS & - & 30 & ND \\
\hline 23 & L7 & TPGS-750-M & PEG-200 & $22^{\circ} \mathrm{C}$ & PMHS & - & 27 & ND \\
\hline 24 & L7 & TPGS-750-M & toluene & $0-22^{\circ} \mathrm{C}$ & PMHS & - & 92 & 97 \\
\hline $25^{d}$ & L7 & TPGS-750-M & toluene & $0-22^{\circ} \mathrm{C}$ & PMHS & - & 87 & 96 \\
\hline $26^{e}$ & L7 & TPGS-750-M & toluene & $0-22^{\circ} \mathrm{C}$ & PMHS & - & 35 & ND \\
\hline 27 & L7 & TPGS-750-M & toluene & $0-22^{\circ} \mathrm{C}$ & TMDS & - & 47 & 92 \\
\hline 28 & L7 & toluene & - & $22^{\circ} \mathrm{C}$ & PMHS & - & 97 & 93 \\
\hline 29 & L7 & toluene & - & $0-22^{\circ} \mathrm{C}$ & PMHS & - & 95 & 96 \\
\hline 30 & L1 & TPGS-750-M & toluene & $0-22^{\circ} \mathrm{C}$ & PMHS & - & 28 & 90 \\
\hline $31^{\mathrm{f}}$ & L7 & TPGS-750-M & toluene & $0-22^{\circ} \mathrm{C}$ & PMHS & - & 81 & 96 \\
\hline 32 & L7 & TPGS-750-M & toluene & $0-22^{\circ} \mathrm{C}$ & PMHS & $\mathrm{NaCl}(3 \mathrm{M})$ & 0 & - \\
\hline 33 & $(S)-\mathbf{L 7}$ & TPGS-750-M & toluene & $0-22^{\circ} \mathrm{C}$ & PMHS & - & 68 & -95 \\
\hline
\end{tabular}

Unless otherwise noted, all reactions were carried out using $0.1 \mathrm{mmol} \mathrm{1a}, 3 \mathrm{~mol} \%$ copper(II) acetate, $3.3 \mathrm{~mol}$ $\%$ ligand, $0.5 \mathrm{~mL}$ solvent, $35 \mu \mathrm{L}$ co-solvent, $0.6 \mathrm{mmol}$ PMHS ( $0.1 \mathrm{mmol}$ added every $25 \mathrm{~min})$, and surfactant at 2 wt \%. All reactions were carried out under an inert atmosphere. Yields refer to isolated material and were determined by weight; ee's were determined by chiral HPLC. a $5 \mathrm{~mol} \%$ copper(II) acetate and $5.5 \mathrm{~mol} \%$ ligand. bPMHS added all at once. 8 mol \% copper(II) acetate, 8.8 mol \% ligand. ${ }^{\mathrm{d}} 4 \mathrm{wt} \%$ TPGS-750-M. e $0.25 \mathrm{~mL}$ TPGS$750-\mathrm{M}$ and $18 \mu \mathrm{L}$ co-solvent. fPerformed using method B. 


\subsection{HPLC analysis of products from optimization trials}

Racemic standard<smiles>COc1ccc2cc(C(C)O)ccc2c1</smiles>

rac-1b: $0 \%$ ee

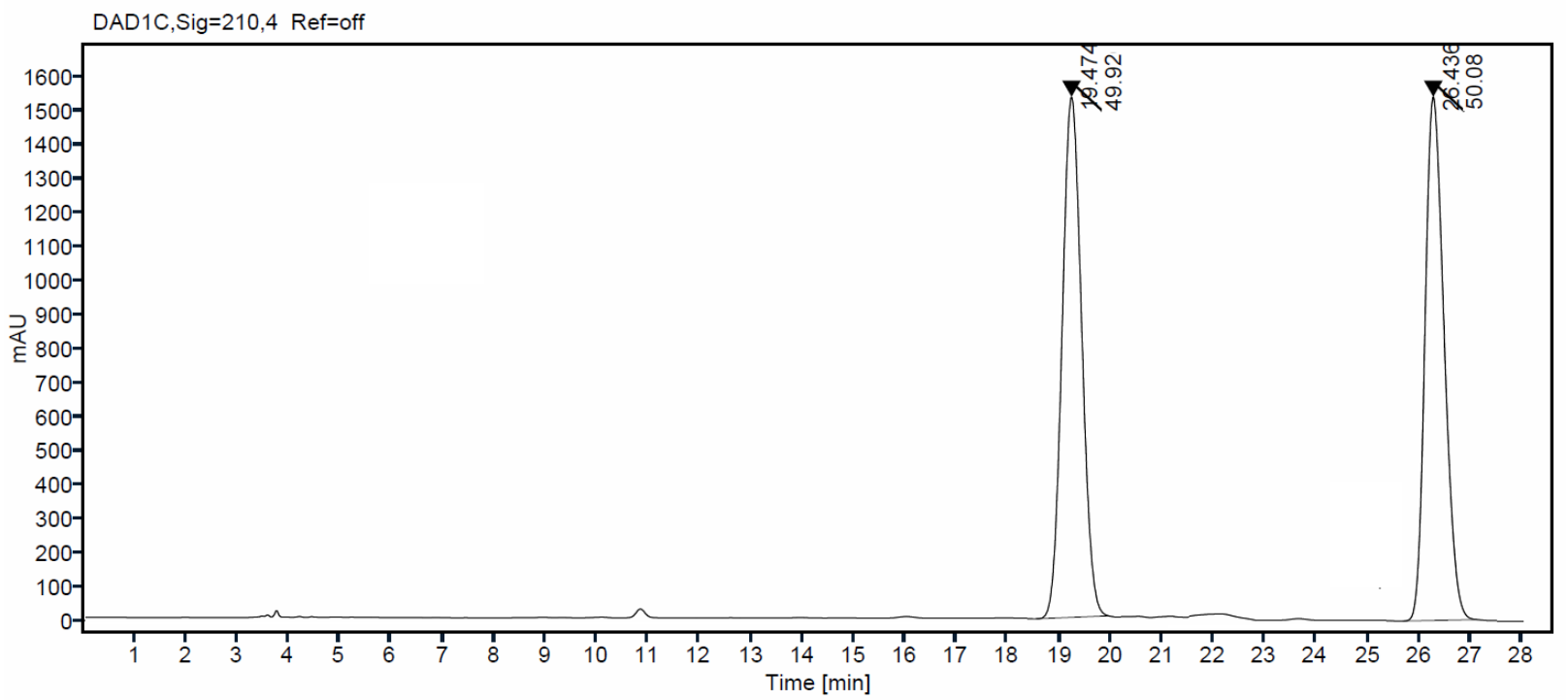

\section{Single Injection Report}

\section{Agilent Technologies}

$\begin{array}{crr}\text { Signal: } & \text { DAD1C, Sig }=210,4 \text { Ref=off } & \\ \text { RT [min] } & \text { Area } & \text { Area\% } \\ 19.474 & 936.7546 & 49.9248 \\ 26.436 & 939.5751 & 50.0752 \\ \text { Sum } & 1876.3297 & \end{array}$


Entry 10: $(R)$-L7<smiles>COc1ccc2cc(C(C)O)ccc2c1</smiles>

(R)-1b: 93\% ee

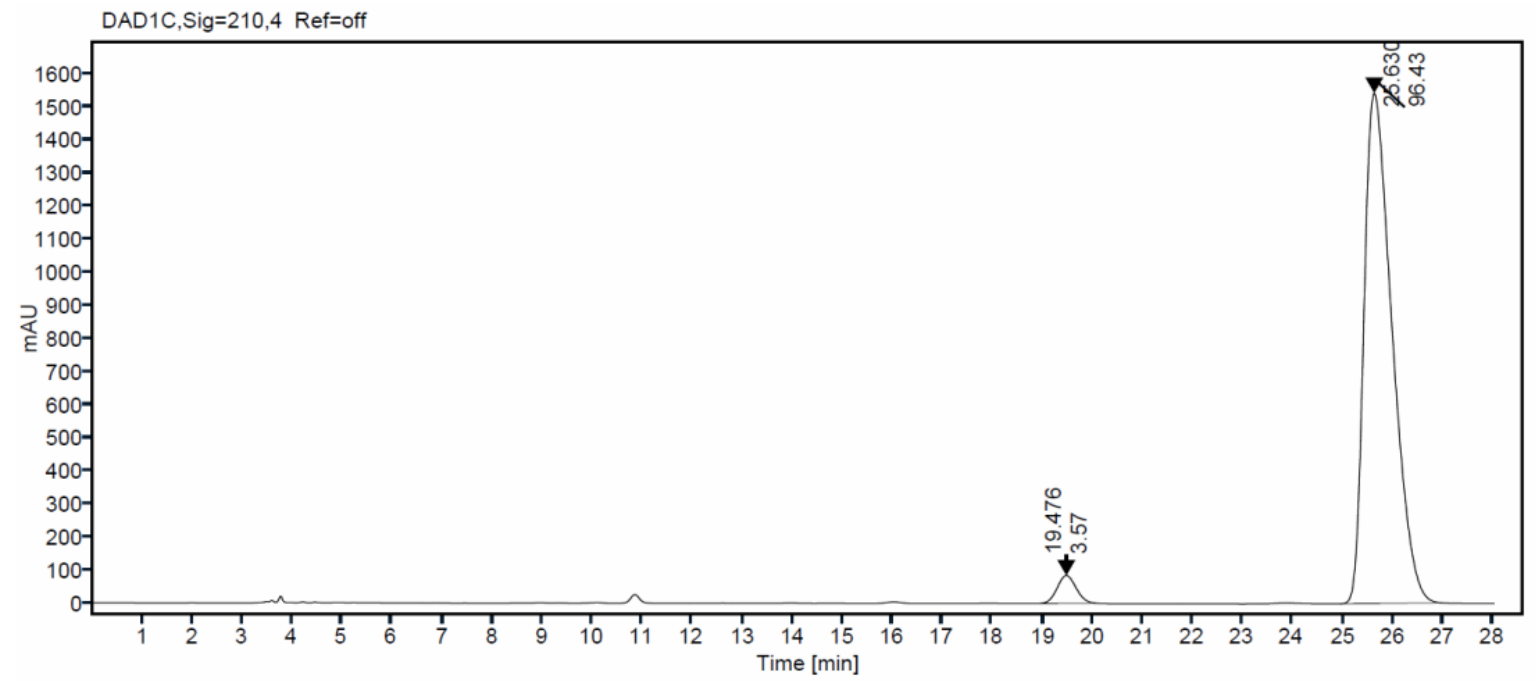

\section{Single Injection Report}

Agilent Technologies

Signal: $\quad$ DAD1C, $\operatorname{Sig}=210,4$ Ref=off

RT [min]

19.476

25.630

Sum
Area

2213.7819

59841.5534

62055.3353
Area $\%$

3.5674

96.4326 
Entry 12: $(S)-\mathbf{L} 3$<smiles>COc1ccc2cc([C@@H](C)O)ccc2c1</smiles>

$(S)-\mathbf{1 b}:-84 \%$ ee

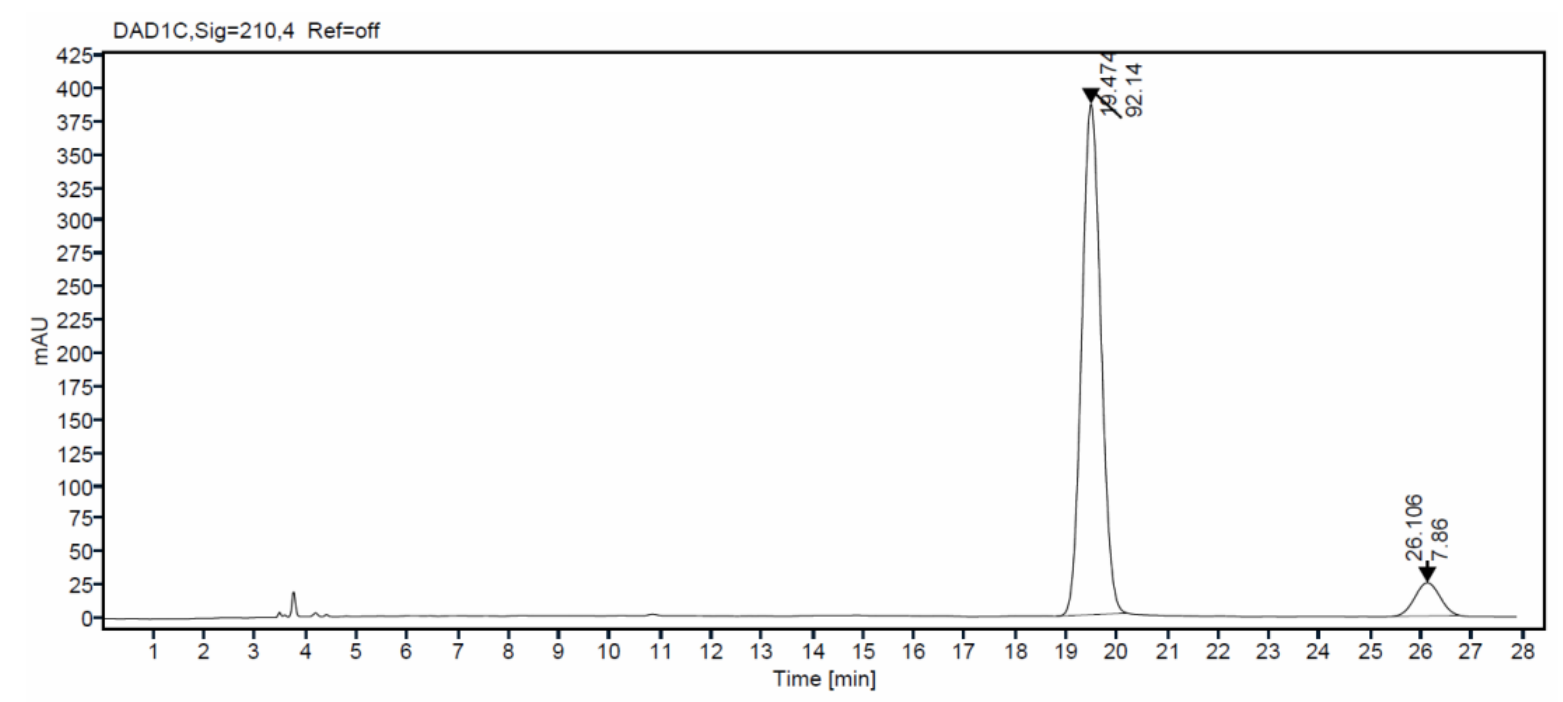

\section{Single Injection Report}

\section{Agilent Technologies}

\begin{tabular}{|c|c|c|c|}
\hline Signal: & $\begin{array}{r}\text { DAD1C,Sig } \\
\text { RT [min] }\end{array}$ & Area & Area $\%$ \\
\hline & 19.474 & 10115.4445 & 92.1425 \\
\hline & 26.106 & 862.6030 & 7.8575 \\
\hline & Sum & 10978.0475 & \\
\hline
\end{tabular}


Entry 13: $\left(R, S_{\mathrm{P}}\right)-\mathbf{L} 9$<smiles>COc1ccc2cc([C@@H](C)O)ccc2c1</smiles>

$(R)-\mathbf{1 b}: 18 \%$ ee

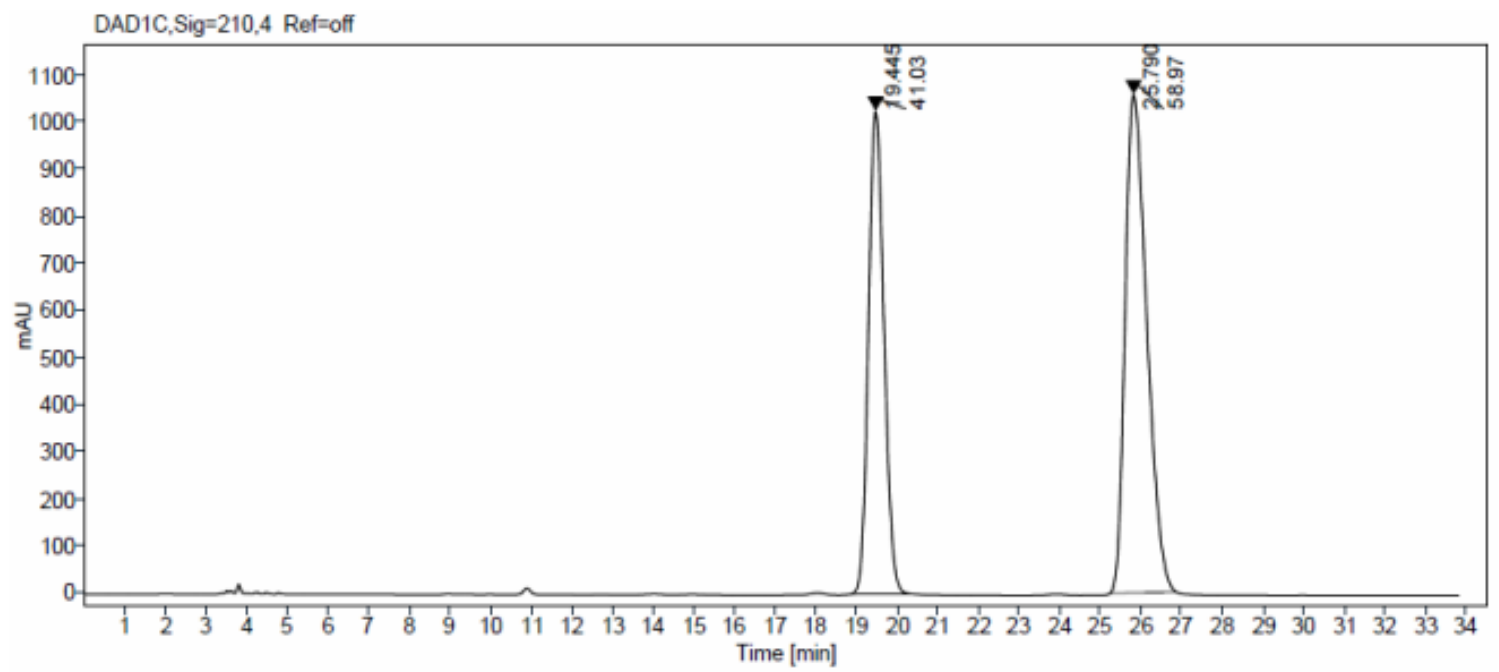

\section{Single Injection Report}

Agilent Technologies

Signal: $\quad$ DAD1C, $\operatorname{Sig}=210,4$ Ref $=$ off

$\begin{array}{rr}\text { RT [min] } & \text { Area } \\ 19.445 & 27115.1062 \\ 25.790 & 38967.9345 \\ \text { Sum } & 66083.0407\end{array}$


Entry 14: $(S)-\mathbf{L 3}$<smiles>COc1ccc2cc(C(C)O)ccc2c1</smiles>

$(S)-\mathbf{1 b}:-79 \%$ ee

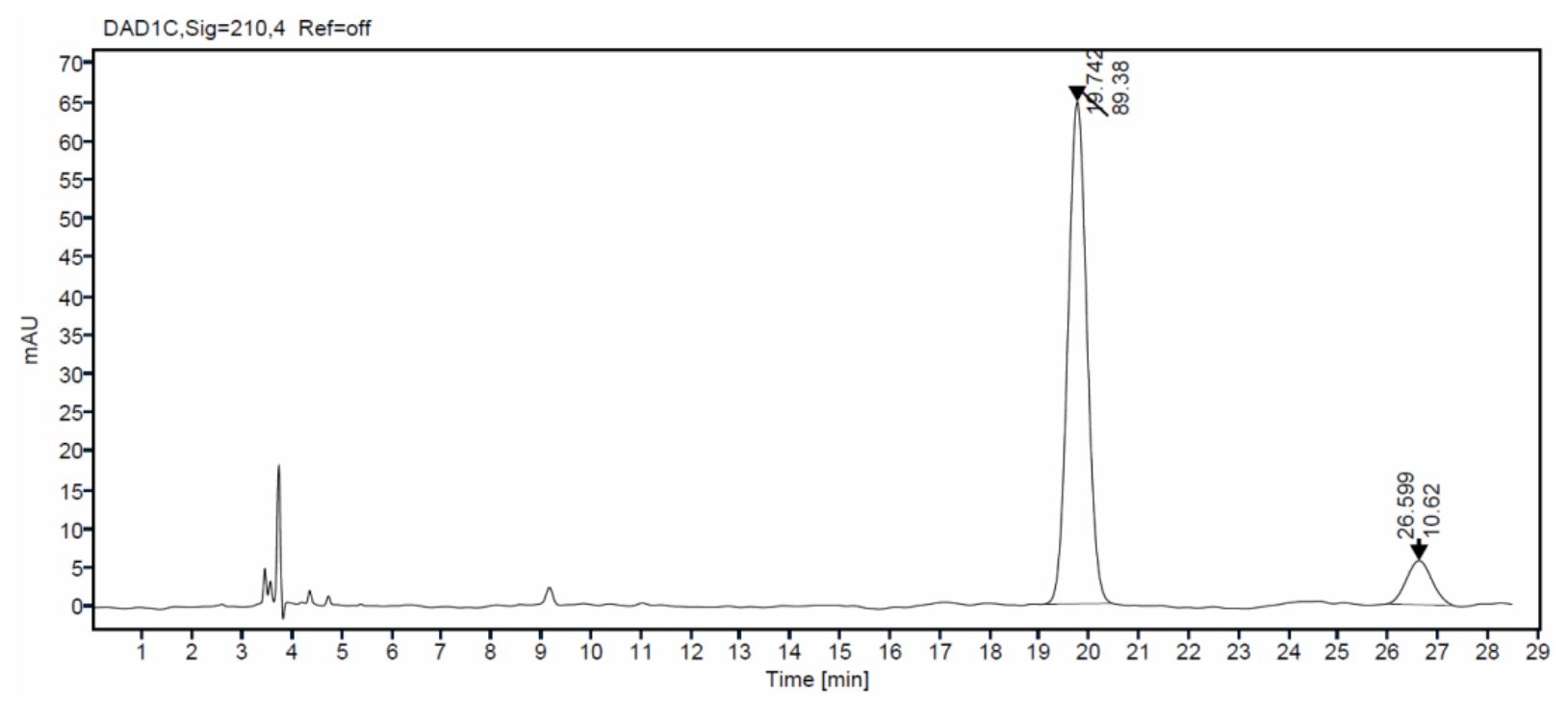

\section{Single Injection Report}

\section{Agilent Technologies}

Signal: $\quad$ DAD1C, $\operatorname{Sig}=210,4$ Ref $=$ off

$\begin{array}{rrr}\text { RT [min] } & \text { Area } & \text { Area\% } \\ 19.742 & 1703.5836 & 89.3798 \\ 26.599 & 202.4217 & 10.6202 \\ \text { Sum } & 1906.0053 & \end{array}$


Entry 15: $(R)$-L5<smiles>COc1ccc2cc(C(C)O)ccc2c1</smiles>

$(R)-\mathbf{1 b}: 81 \%$ ee

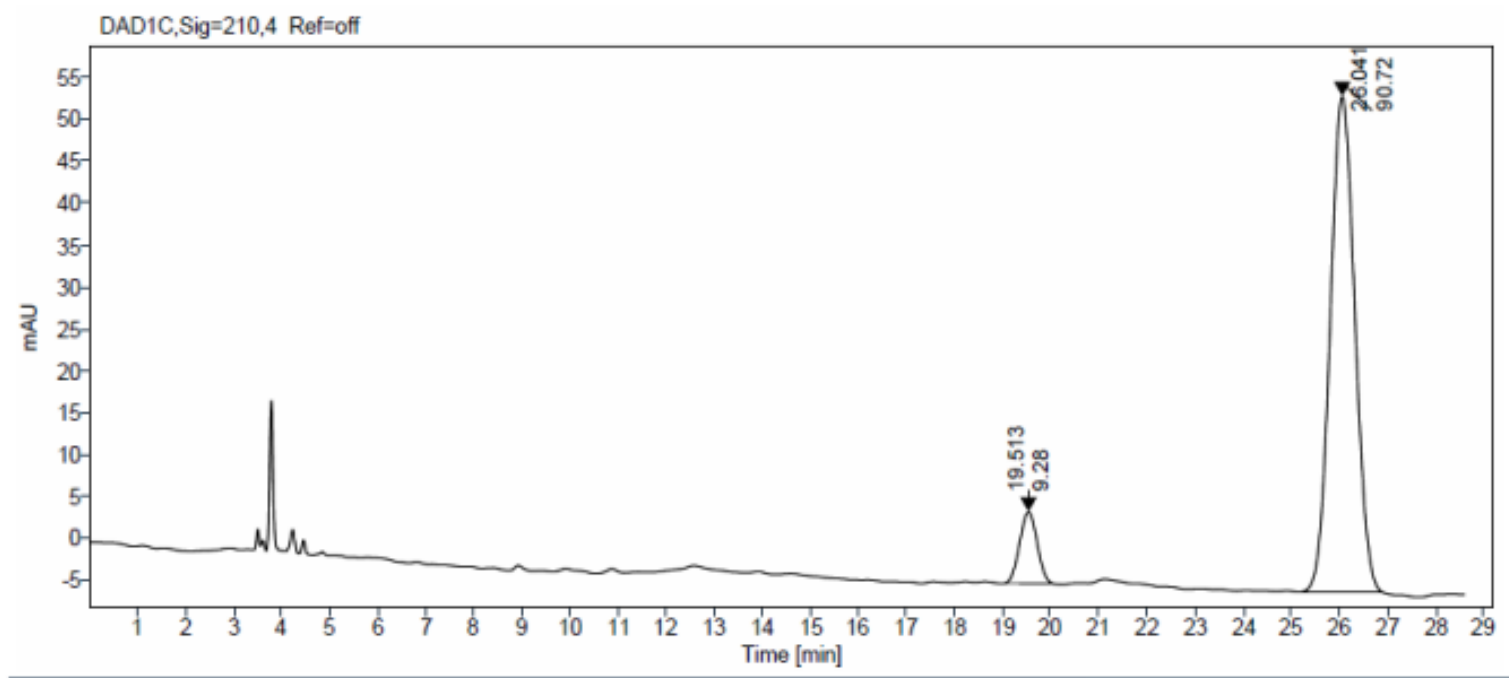

\section{Single Injection Report}

Agilent Technologies

Signal: $\quad$ DAD1C,, ig $=210,4$ Ref $=$ off

RT [min]
19.513
26.041
Sum

Area

Area $\%$

9.513

215.2484

9.2782

Sum

2104.6855

90.7218 
Entry 16: $(R)-\mathbf{L 6}$<smiles>COc1ccc2cc([C@@H](C)O)ccc2c1</smiles>

$(R)-\mathbf{1 b}: \mathbf{8 7 \%}$ ee

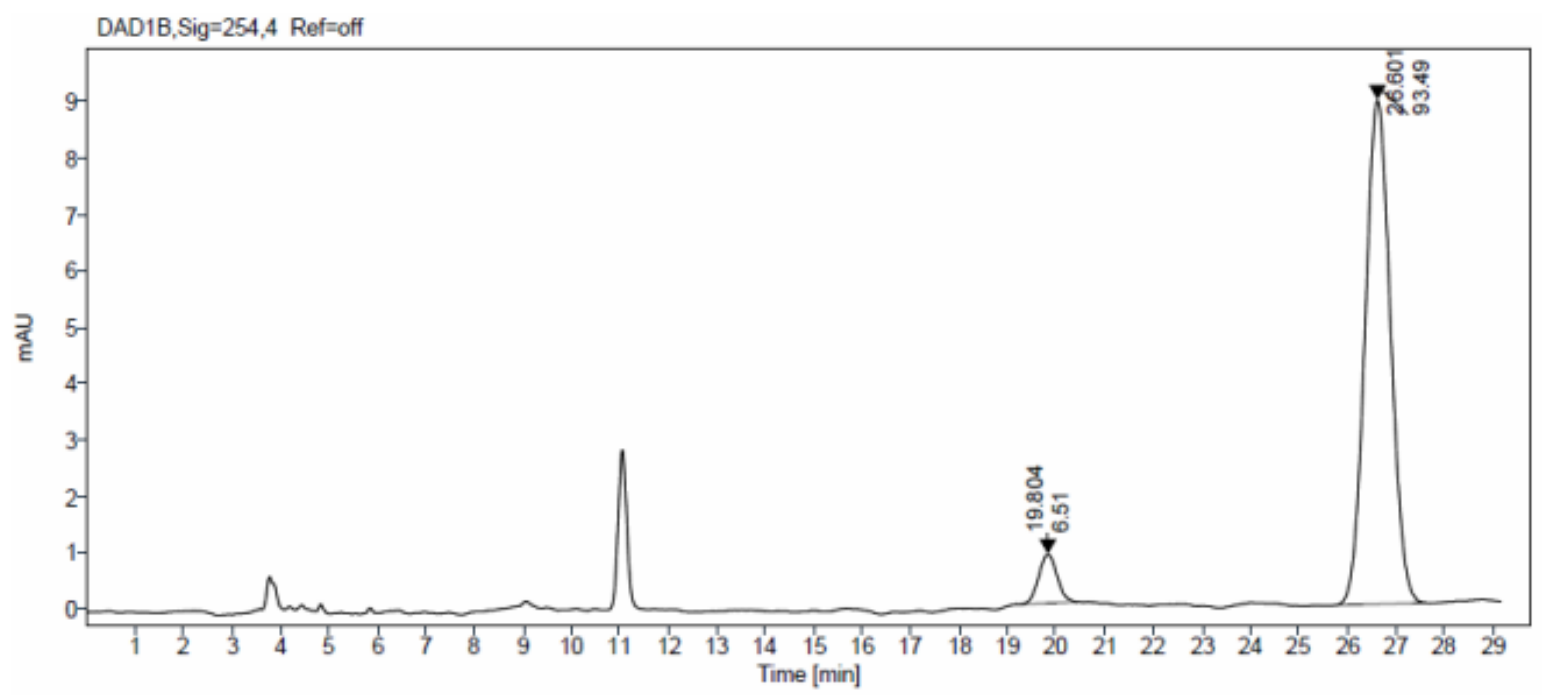

\section{Single Injection Report}

Signal: $\quad$ DAD1B, Sig $=254,4$ Ref $=$ off

$\begin{array}{rrr}\text { RT [min] } & \text { Area } & \text { Area\% } \\ 19.804 & 22.7321 & 6.5067 \\ 26.601 & 326.6296 & 93.4933 \\ \text { Sum } & 349.3617 & \end{array}$


Entry 17: (S)-L2<smiles>COc1ccc2cc(C(C)O)ccc2c1</smiles>

$(S)-\mathbf{1 b}:-74 \%$ ee

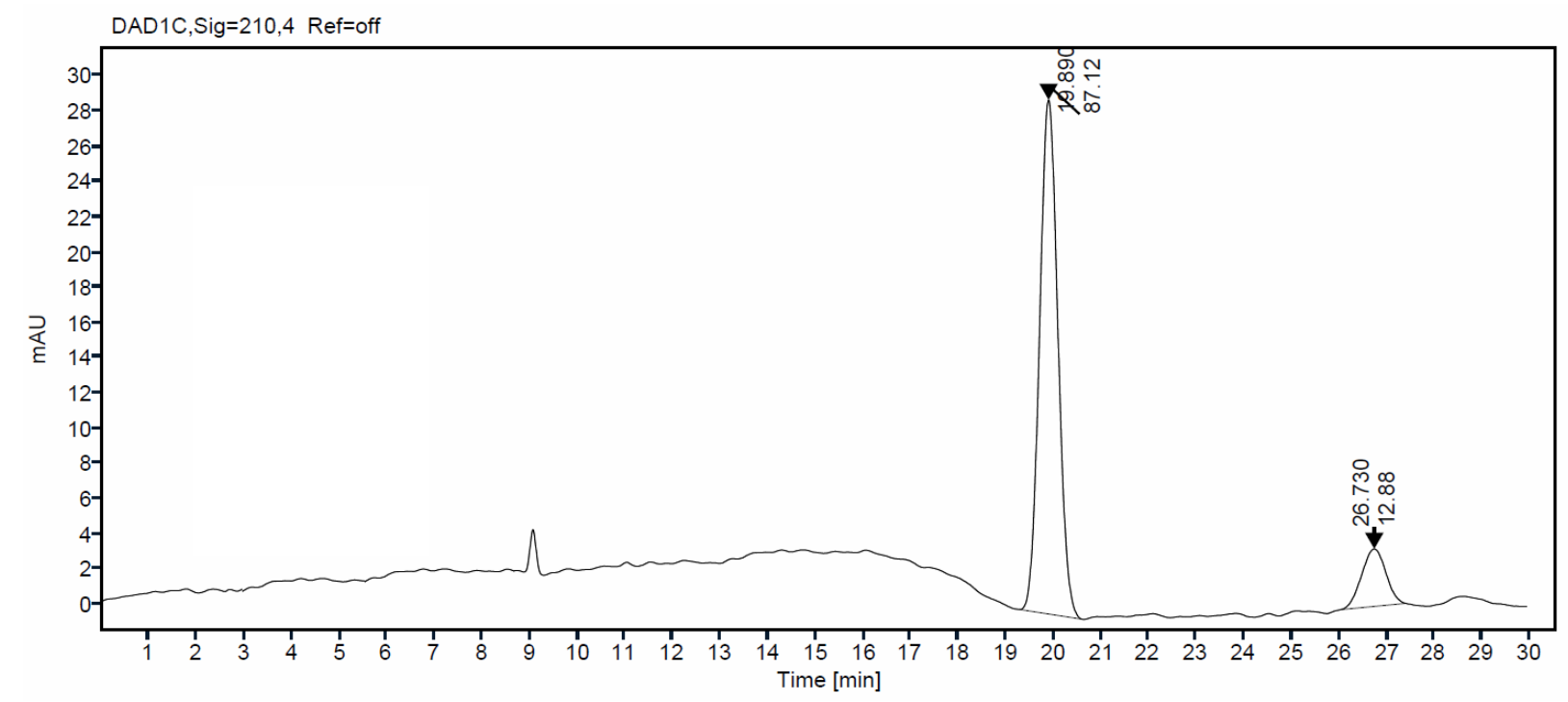

\section{Single Injection Report}

Agilent Technologies

Signal: $\quad$ DAD1C, $\operatorname{Sig}=210,4$ Ref $=$ off

$\begin{array}{rrr}\text { RT [min] } & \text { Area } & \text { Area\% } \\ 19.890 & 778.7765 & 87.1195 \\ 26.730 & 115.1414 & 12.8805 \\ \text { Sum } & 893.9179 & \end{array}$


Entry 18: $(R)-\mathbf{L 4}$<smiles>COc1ccc2cc([C@@H](C)O)ccc2c1</smiles>

$(R)-\mathbf{1 b}: \mathbf{8 7 \%}$ ee

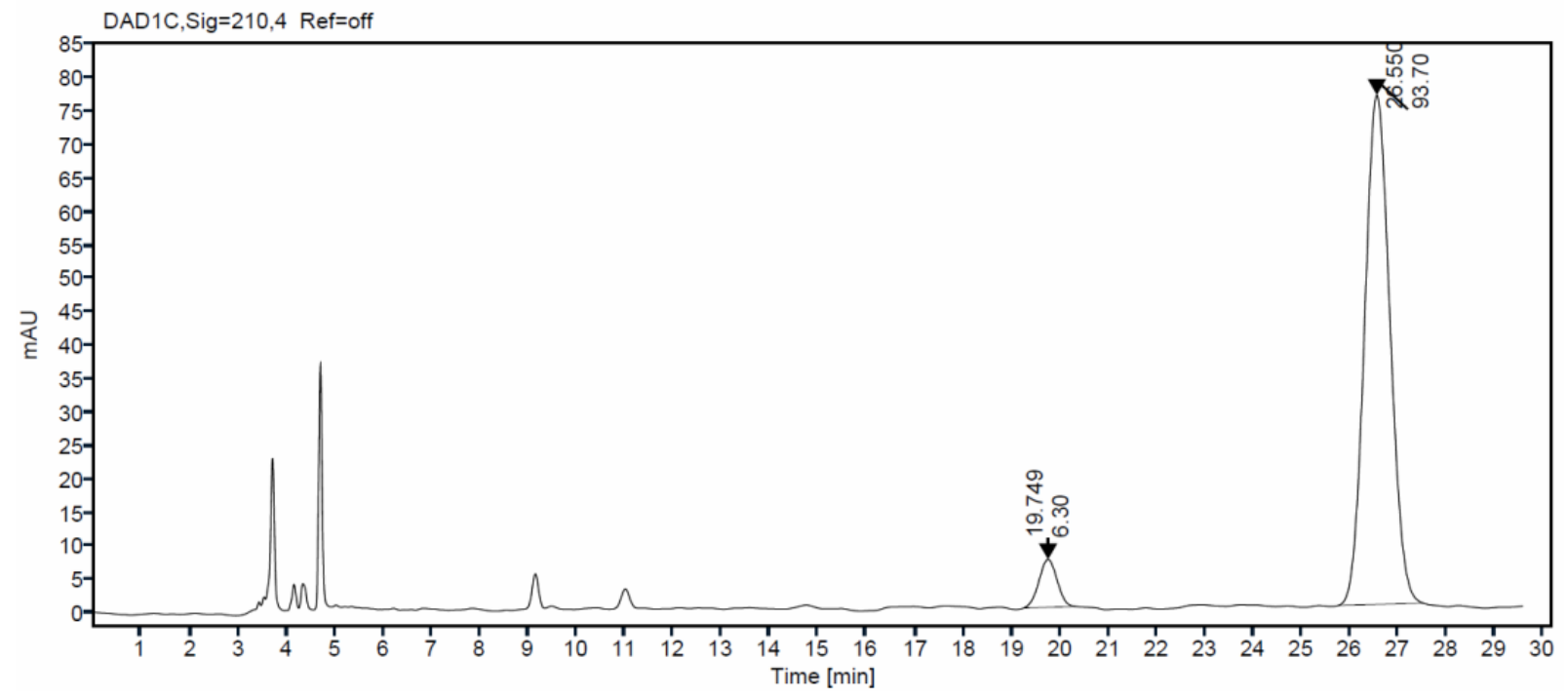

\section{Single Injection Report}

\section{Agilent Technologies}

\begin{tabular}{|c|c|c|c|}
\hline Signal: & $\begin{array}{r}\text { DAD1C,Sig } \\
\text { RT [min] }\end{array}$ & Area & Area $\%$ \\
\hline & 19.749 & 186.2911 & 6.3048 \\
\hline & 26.550 & 2768.4628 & 93.6952 \\
\hline & Sum & 2954.7539 & \\
\hline
\end{tabular}


Entry 19: $(R)-\mathbf{L 7}$<smiles>COc1ccc2cc([C@@H](C)O)ccc2c1</smiles>

$(R)-\mathbf{1 b}: 95 \%$ ee

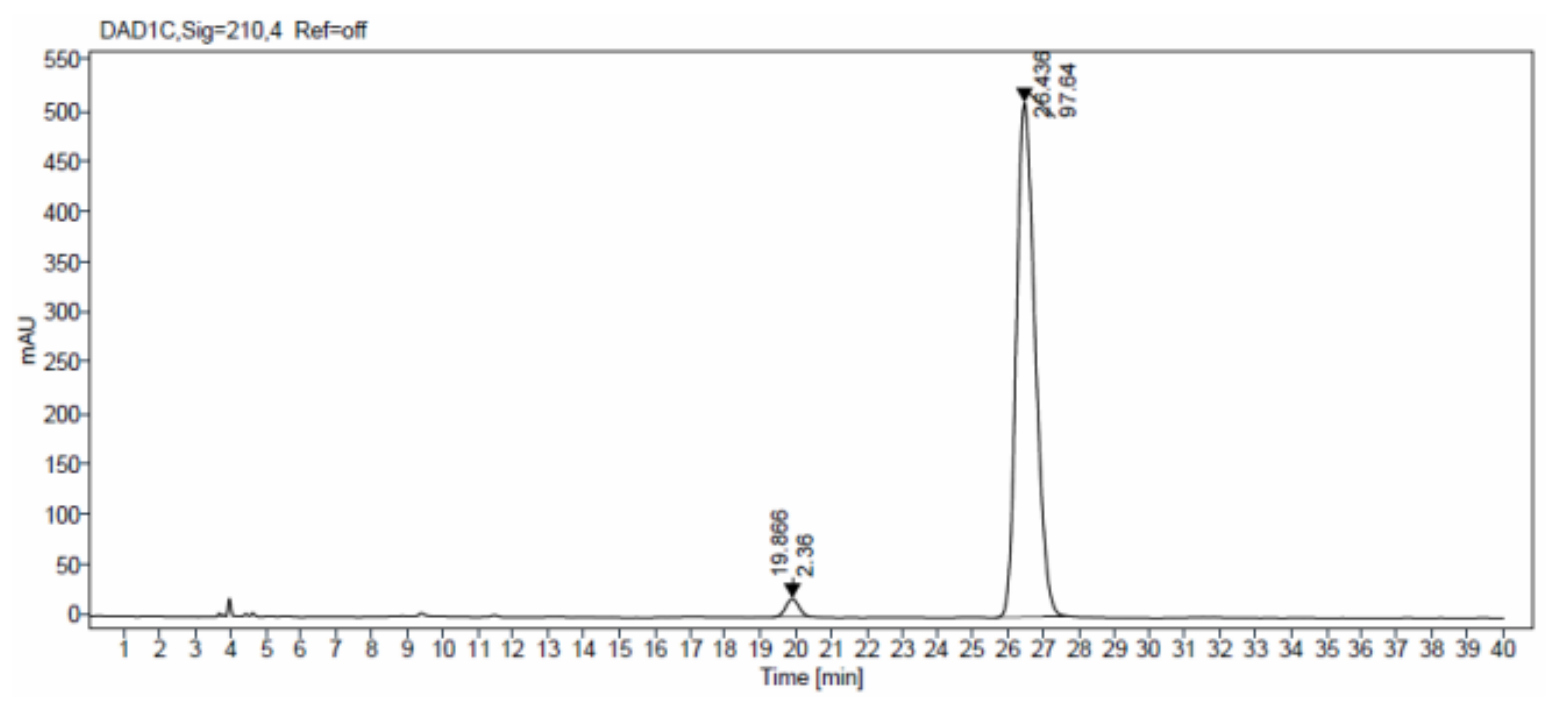

\section{Single Injection Report}

\section{Agilent Technologies}

$\begin{array}{crr}\text { Signal: } & \text { DAD1C, Sig=210,4 Ref=off } & \\ \text { RT [min] } & \text { Area } & \text { Area\% } \\ 19.866 & 452.4053 & 2.3617 \\ 26.436 & 18703.3089 & 97.6383 \\ \text { Sum } & 19155.7142 & \end{array}$


Entry 20: $(R)$-L7<smiles>COc1ccc2cc(C(C)O)ccc2c1</smiles>

(R)-1b: $95 \%$ ee

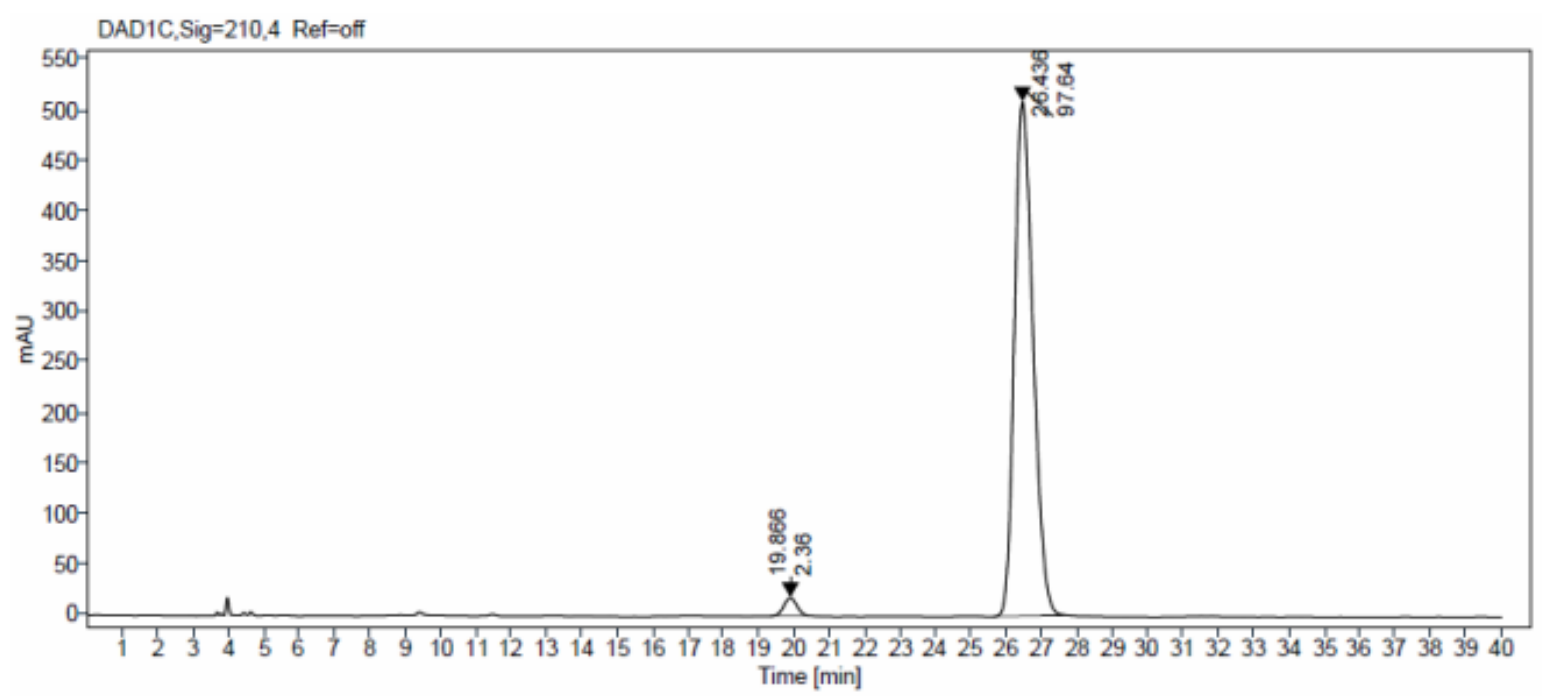

\section{Single Injection Report}

\section{Agilent Technologies}

$\begin{array}{crr}\text { Signal: } & & \\ \text { DAD1C, } \operatorname{Sig}=210,4 \text { Ref }=\text { off } & \text { Area } & \text { Area } \% \\ 19.866 & 452.4053 & 2.3617 \\ 26.436 & 18703.3089 & 97.6383 \\ \text { Sum } & 19155.7142 & \end{array}$


Entry 24: (R)-L7<smiles>COc1ccc2cc([C@@H](C)O)ccc2c1</smiles>

$(R)-\mathbf{1 b}: 97 \%$ ee

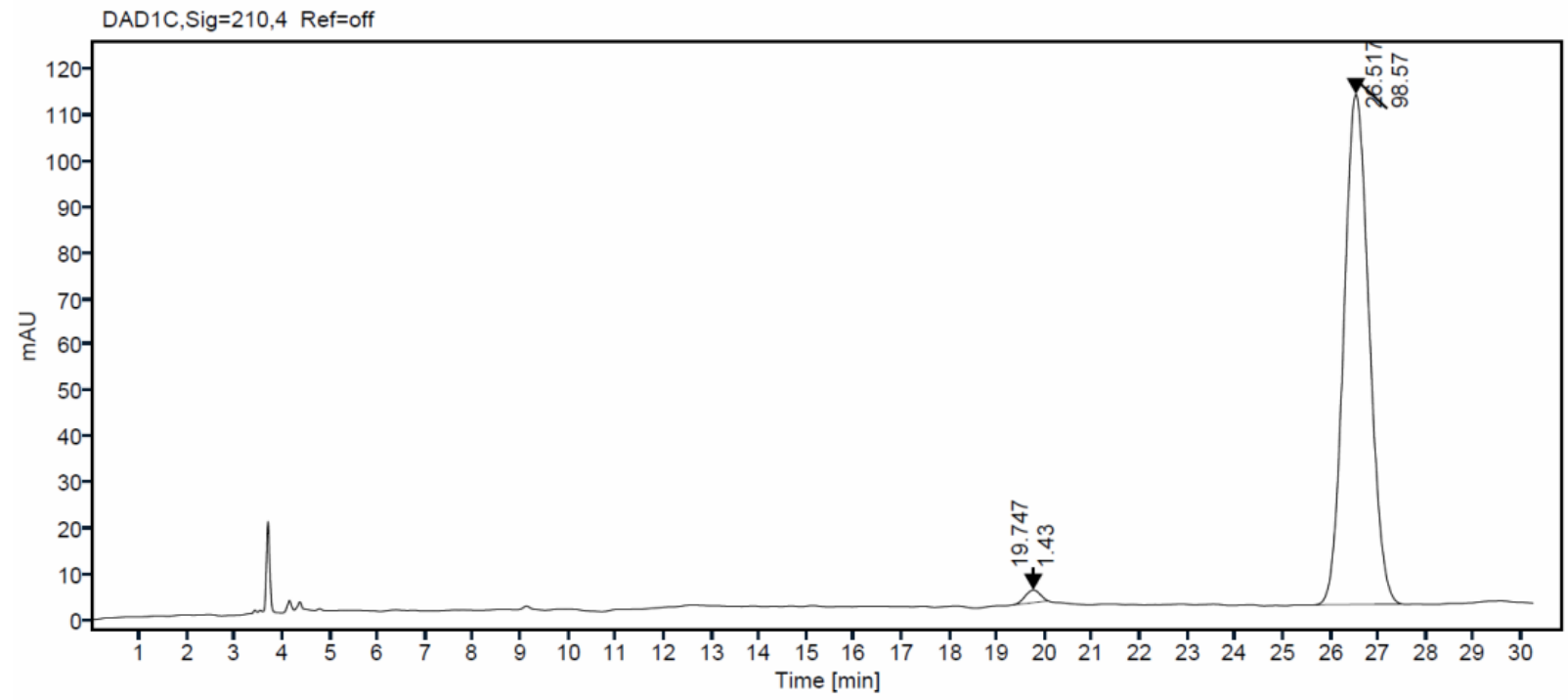

\section{Single Injection Report}

\section{Agilent Technologies}

Signal: DAD1C,Sig=210,4 Ref=off

$\begin{array}{rrr}\text { RT [min] } & \text { Area } & \text { Area\% } \\ 19.747 & 59.3044 & 1.4313 \\ 26.517 & 4084.0916 & 98.5687 \\ \text { Sum } & 4143.3960 & \end{array}$


Entry 25: $(R)-\mathbf{L 7}$<smiles>COc1ccc2cc(C(C)O)ccc2c1</smiles>

(R)-1b: $96 \%$ ee

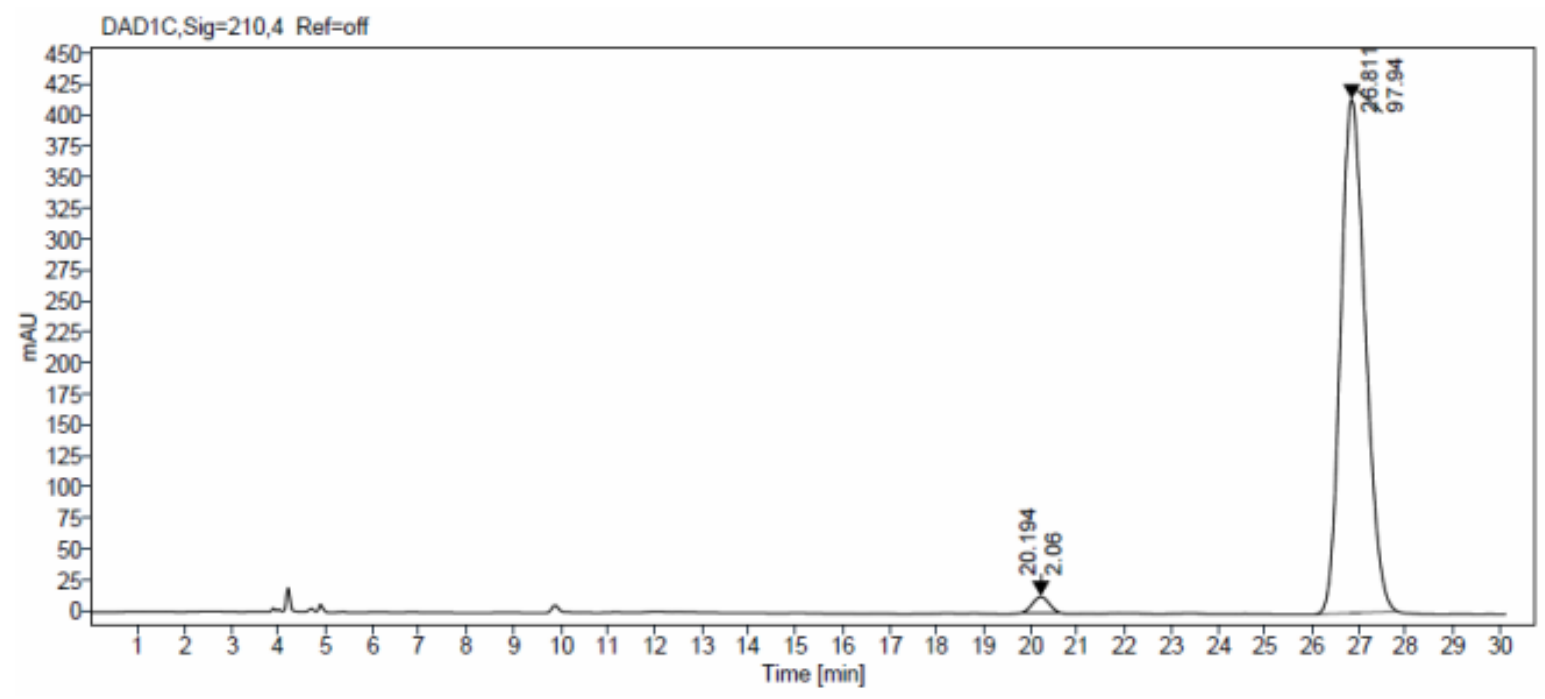

Single Injection Report

Agilent Technologies

Signal: $\quad$ DAD1C, $\operatorname{Sig}=210,4$ Ref $=$ off

$\begin{array}{rrr}\text { RT [min] } & \text { Area } & \text { Area\% } \\ 20.194 & 317.6857 & 2.0561 \\ 26.811 & 15133.4858 & 97.9439 \\ \text { Sum } & 15451.1715 & \end{array}$


Entry 27: $(R)-\mathbf{L 7}$<smiles>COc1ccc2cc(C(C)O)ccc2c1</smiles>

$(R)-\mathbf{1 b}: 92 \%$ ee

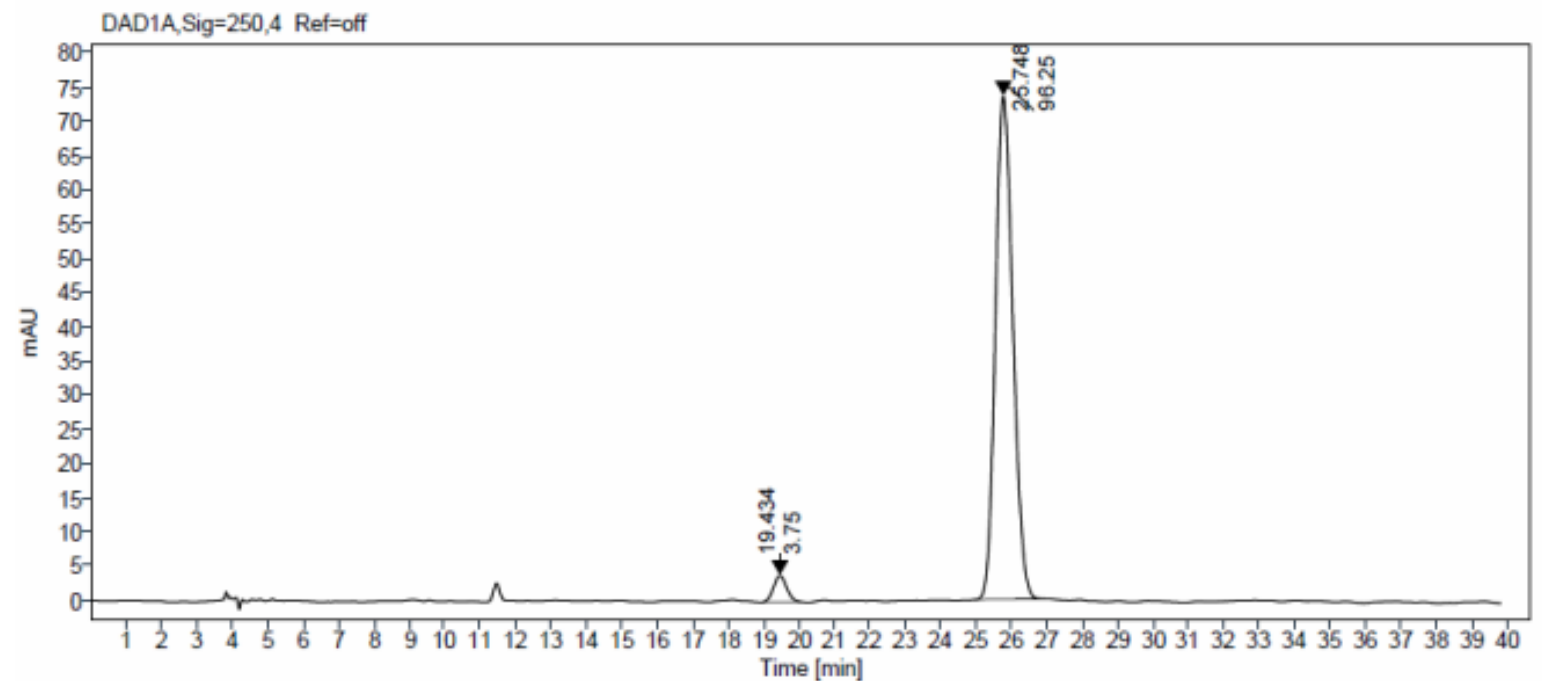

\section{Single Injection Report}

Agilent Technologies

Signal: DAD1A,Sig=250,4 Ref=off

$\begin{array}{rrr}\text { RT }[\text { min] } & \text { Area } & \text { Area\% } \\ 19.434 & 98.6366 & 3.7502 \\ 25.748 & 2531.5309 & 96.2498 \\ \text { Sum } & 2630.1675 & \end{array}$


Entry 28: $(R)-\mathbf{L 7}$<smiles>COc1ccc2cc(C(C)O)ccc2c1</smiles>

$(R)-\mathbf{1 b}: 93 \%$ ee

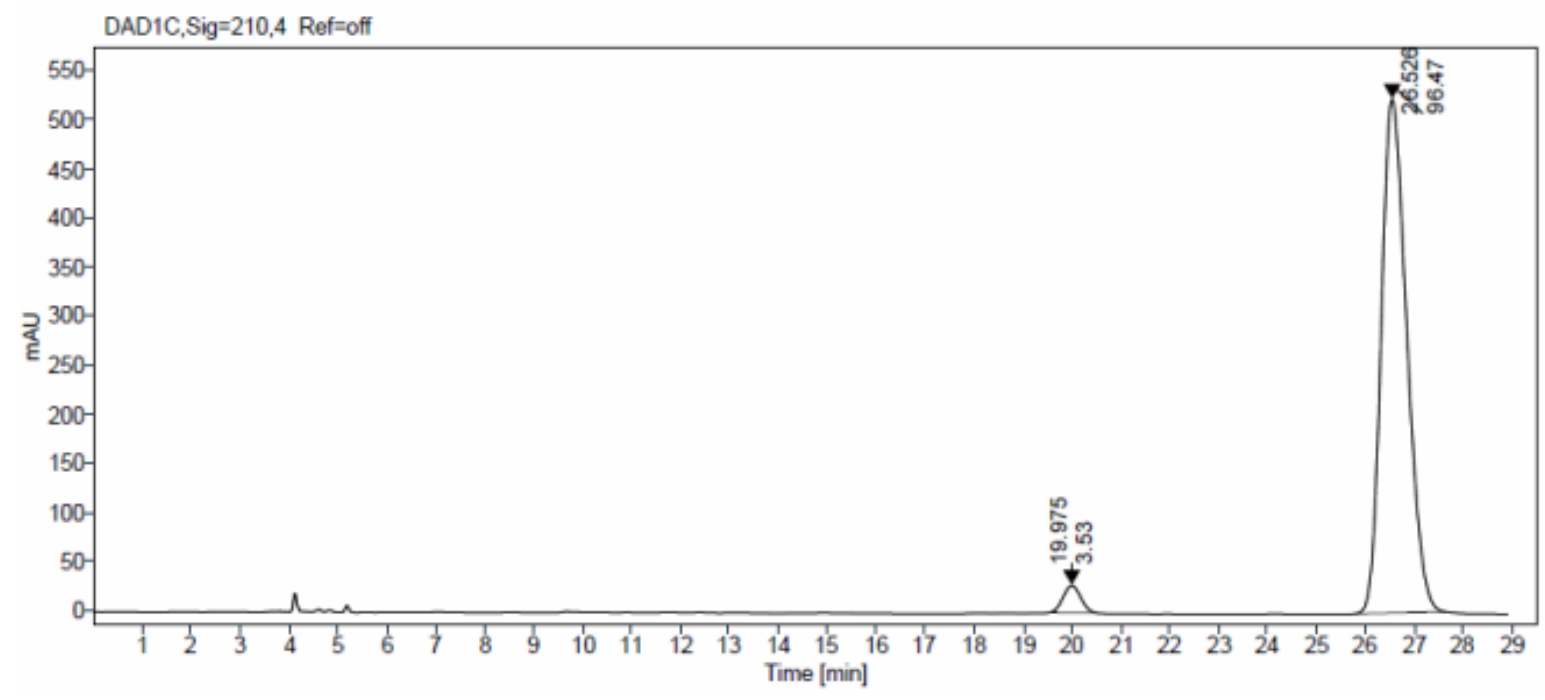

\section{Single Injection Report}

Agilent Technologies

Signal: $\quad$ DAD1C, $\mathrm{Sig}=210,4$ Ref=off
RT $[\mathrm{min}]$
19.975
26.526

$\begin{array}{rr}\text { Area } & \text { Area\% } \\ 692.0107 & 3.5267 \\ 18930.2318 & 96.4733 \\ 19622.2426 & \end{array}$


Entry 29: $(R)$-L7<smiles>COc1ccc2cc(C(C)O)ccc2c1</smiles>

(R)-1b: $96 \%$ ee

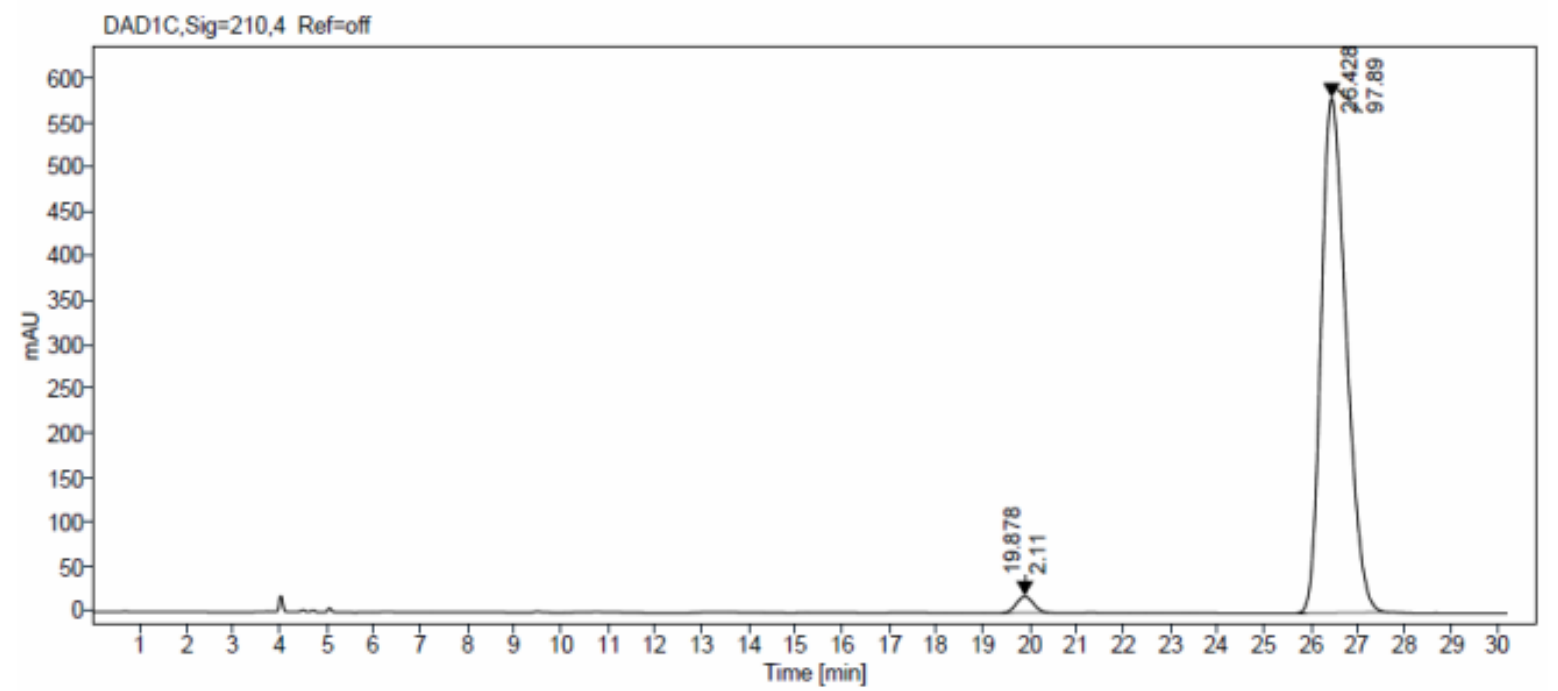

\section{Single Injection Report}

Agilent Technologies

Signal: DAD1C, Sig=210,4 Ref=off

$\begin{array}{rrr}\text { RT }[\text { min] } & \text { Area } & \text { Area\% } \\ 19.878 & 464.9980 & 2.1119 \\ 26.428 & 21553.4366 & 97.8881 \\ \text { Sum } & 22018.4346 & \end{array}$


Entry 30: $(R)-\mathbf{L 1}$<smiles>COc1ccc2cc([C@@H](C)O)ccc2c1</smiles>

$(R)-\mathbf{1 b}$ : $96 \%$ ee

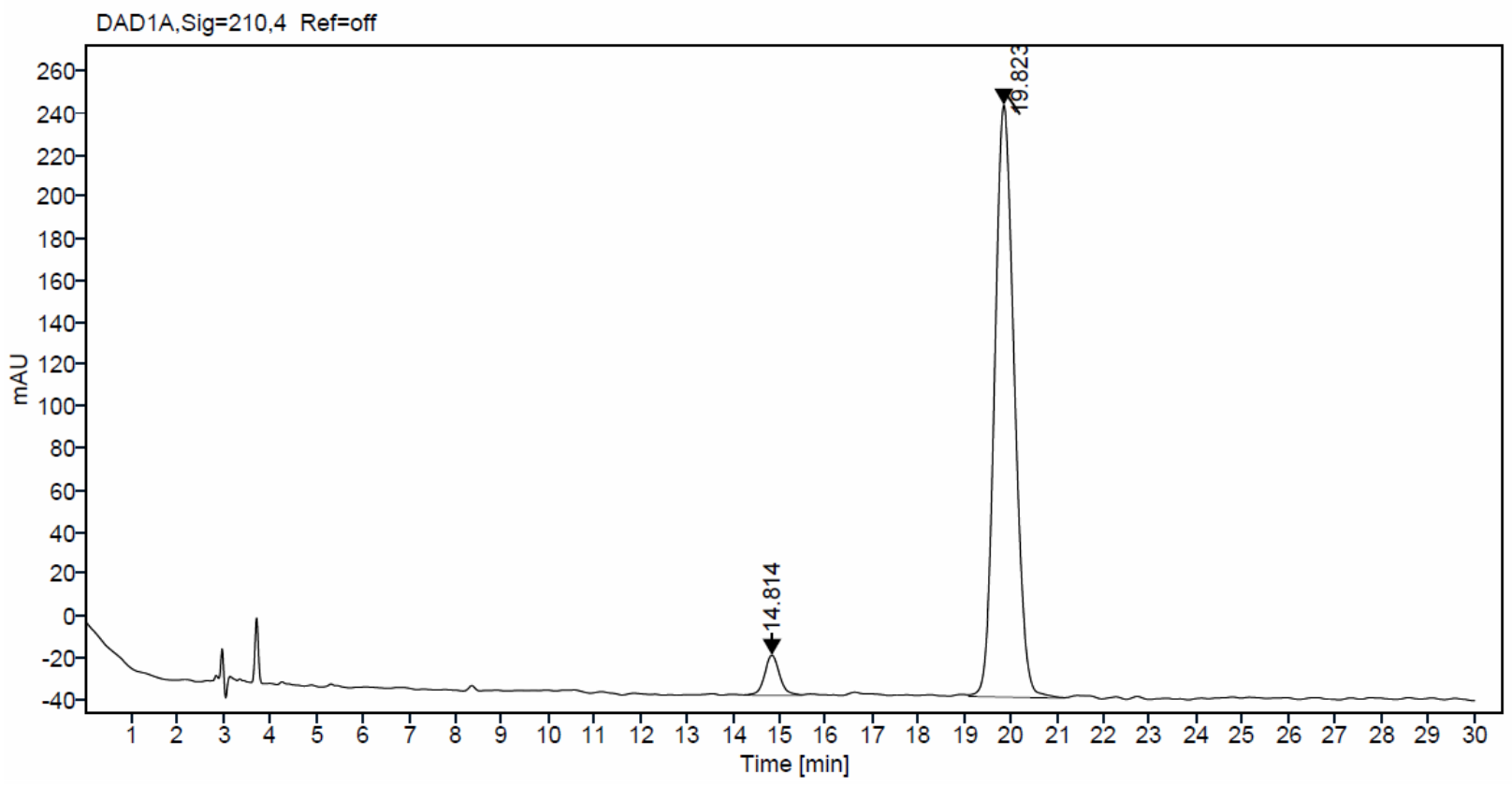

\section{Single Injection Report}

\begin{tabular}{rrr}
\multicolumn{1}{l}{$\begin{array}{l}\text { Signal: } \\
\text { RT [min] }\end{array}$} & $\begin{array}{c}\text { DAD1A,Sig }=210,4 \\
\text { Ref }=\text { off }\end{array}$ \\
14.814 & 431.7244 & Area $\%$ \\
19.823 & 8322.9114 & 95314 \\
Sum & 8754.6358 &
\end{tabular}


Entry 31: $(R)-\mathbf{L 7}$<smiles>COc1ccc2cc(C(C)O)ccc2c1</smiles>

(R)-1b: $96 \%$ ee

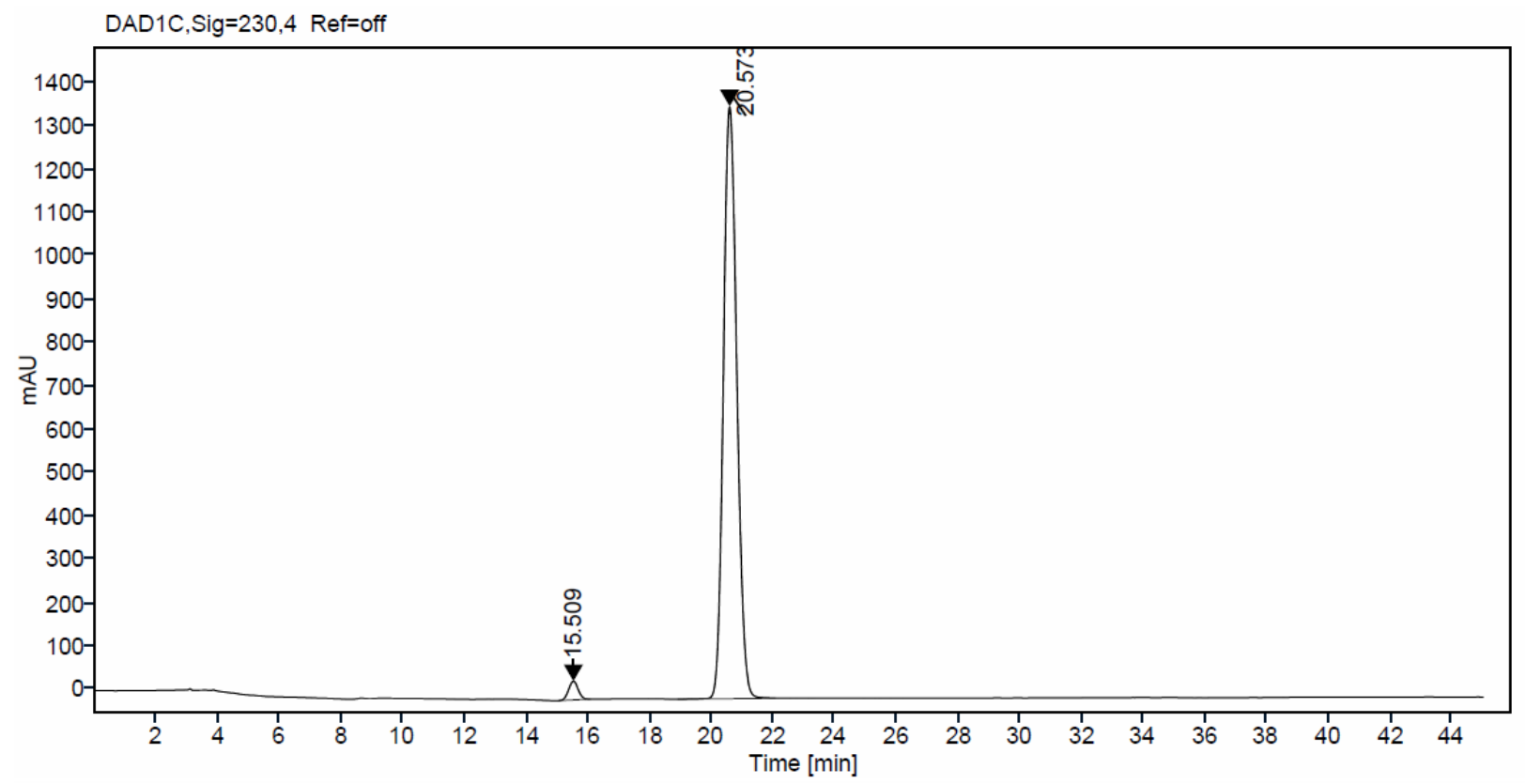

\section{Single Injection Report}

\begin{tabular}{|c|c|c|}
\hline Signal: & $\mathrm{DAD} 1 \mathrm{C}, \mathrm{Sig}=230,4$ & Ref $=$ off \\
\hline RT [min] & Area & Area $\%$ \\
\hline 15.509 & 927.8327 & 2.1973 \\
\hline 20.573 & 41297.6951 & 97.8027 \\
\hline Sum & 42225.5278 & \\
\hline
\end{tabular}


Entry 33: $(S)-\mathbf{L} 7$<smiles>COc1ccc2cc([C@@H](C)O)ccc2c1</smiles>

$(S)-\mathbf{1 b}: 95 \%$ ee

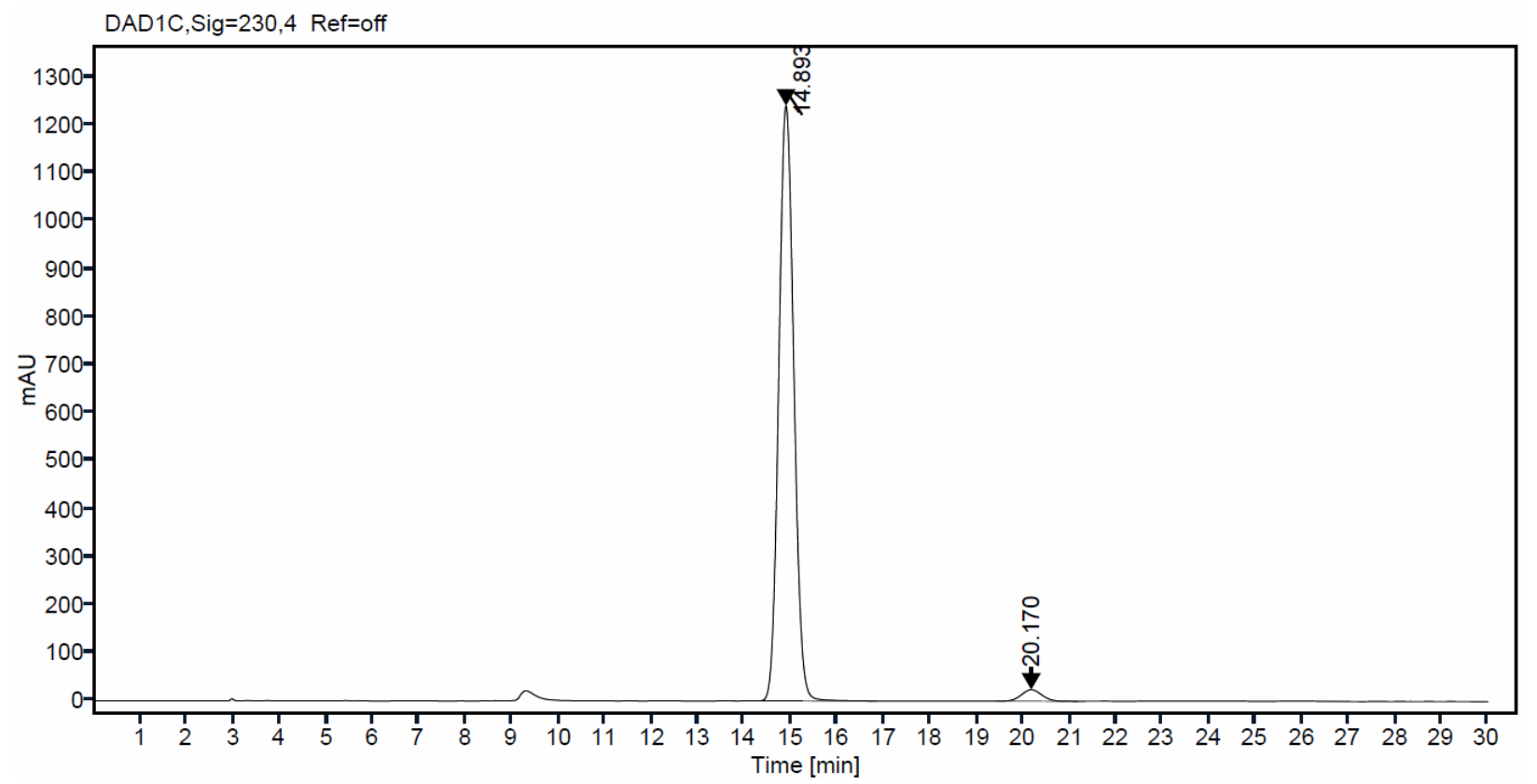

\section{Single Injection Report}

Agilent Technologies

\begin{tabular}{rrr}
\multicolumn{1}{l}{$\begin{array}{l}\text { Signal: } \\
\text { RT [min] }\end{array}$} & DAD1C, Aig $=230,4$ & Ref $=$ off \\
14.893 & 27888.0073 & Area $\%$ \\
20.170 & 733.4937 & 2.5627 \\
Sum & 28621.5010 &
\end{tabular}




\section{Reaction procedures}

\subsection{General procedures for the asymmetric reduction of aryl/heteroaryl ketones}

Method A: In a flame-dried, 1-dram vial equipped with a PTFE-coated magnetic stir bar, $\mathrm{Cu}(\mathrm{OAc})_{2} \cdot \mathrm{H}_{2} \mathrm{O}(3.0 \mathrm{~mol} \%)$ and ketone $(0.1 \mathrm{mmol}$; if solid) were added. The reaction was capped with a rubber septum and transferred to an argon-filled glovebox. Nonracemic ligand (3.3 mol \%) was weighed and the reaction was capped and taken out of the glovebox then put under Ar using a Schlenk Line. Dry toluene (35 $\mu \mathrm{L}), 2$ wt \% TPGS-750-M/ ${ }_{2} \mathrm{O}(0.5 \mathrm{~mL})$, and ketone (if a liquid) were added. The reaction was stirred at $\mathrm{rt}\left(22{ }^{\circ} \mathrm{C}\right)$ for $1.5 \mathrm{~h}$, then put in the ice bath. PMHS was added over $2 \mathrm{~h}$ using a Hamilton syringe ( 6.0 equiv, $7 \mu \mathrm{L}$ of PMHS every $25 \mathrm{~min}$ ). The ice bath was then removed and the reaction was quickly capped and stirred overnight at rt. After completion, the reaction vial was opened (caution: hydrogen gas above atmospheric pressure is evolved by the reaction and is released upon opening the reaction vial) and quenched by addition of a saturated solution of $\mathrm{NH}_{4} \mathrm{~F}$ in $\mathrm{MeOH}(0.25 \mathrm{~mL})$ in an ice bath. The ice bath was then removed, and the reaction was stirred at $r$ for $2 \mathrm{~h}$. The mixture was extracted in the reaction vial with EtOAc $(3 \times 0.5 \mathrm{~mL})$ and the pooled extracts were passed through a silica plug. The remaining aqueous mixture was then passed through the silica plug and eluted with EtOAc. The combined organic phases were dried over $\mathrm{MgSO}_{4}$, deposited onto silica, and purified by flash chromatography on silica to afford the targeted chiral alcohols. The product was analyzed with HPLC to determine the enantiomeric excess.

Method B: A stock solution of ligated Cu(II) was prepared as follows. To a 2-dram glass vial equipped with a stir bar, $\mathrm{Cu}(\mathrm{OAc})_{2} \cdot \mathrm{H}_{2} \mathrm{O}(9.6 \mathrm{mg}, 48 \mu \mathrm{mol})$ was added. The vial was sealed with a rubber stopper and purged with argon. In an argon-filled glove box, $(R)-3,4,5-\mathrm{MeO}$ MeO-BIPHEP ( $49.8 \mathrm{mg}, 52.8 \mu \mathrm{mol}$ ) was added. The sealed vial was removed from the glove box and attached to a Schlenk line. Under argon, degassed toluene $(640 \mu \mathrm{L})$ was added and rapid stirring was applied. TPGS-750-M 2 wt \% aqueous solution (8 mL) was then added, creating an emulsion. The emulsion was stirred rapidly for $1.5 \mathrm{~h}$. The stock solution was administered by withdrawing from the rapidly stirring emulsion with a syringe. To an argonpurged reaction vial containing a stir bar and substrate ketone, the appropriate amount of stock solution was added to give a ketone concentration of $0.2 \mathrm{M}$. The reaction emulsion was allowed to stir rapidly at $\mathrm{rt}$ for $15 \mathrm{~min}$. Then, the reaction vial was placed in an ice bath (while maintaining stirring) and a syringe containing the total amount of PMHS (35 $\mu \mathrm{L}$ PMHS per $100 \mu \mathrm{mol}$ ketone) was added portion-wise every $0.5 \mathrm{~h}$ through the rubber stopper. After final addition, the reaction vial was removed from the ice bath and stirred at rt overnight attached to a manifold under argon. (Note: when performed in this manner, the hydrogen generated from the reaction is allowed to escape, and no positive pressure accumulates.) Work-up was performed in the same manner as described in Method A. 


\subsection{General procedure for the synthesis of racemic sec-alcohols standards}

In a 2-dram vial equipped with a magnetic stir bar, the ketone $(0.1 \mathrm{mmol})$ was dissolved in $100 \%$ ethanol $(1 \mathrm{~mL})$ with rapid stirring. $\mathrm{NaBH}_{4}(11 \mathrm{mg}, \sim 0.3 \mathrm{mmol}, \sim 3 \mathrm{eq}$.$) , was then added$ and the solution was stirred at rt. The reaction was monitored by TLC. After total consumption of the ketone, the solvent was removed and the residue was partitioned between ethyl acetate $(1.5 \mathrm{~mL})$ and $3 \mathrm{M}$ aq. $\mathrm{NaCl}(1.5 \mathrm{~mL})$. The organic layer was collected, dried over $\mathrm{Na}_{2} \mathrm{SO}_{4}$, and evaporated to give the racemic sec-alcohol product.

\subsection{Large-scale asymmetric reduction}

The reduction of $6^{\prime}$-methoxy-2'-acetonaphthone $(1 \mathrm{a}, 200.25 \mathrm{~g} / \mathrm{mol})$ was performed on a 5 mmol (1 g) scale. To a $100 \mathrm{~mL}$ Schlenk tube with a side arm, equipped with a stir bar, 1a (1 g; $5 \mathrm{mmol})$ and $\mathrm{Cu}(\mathrm{OAc})_{2} \cdot \mathrm{H}_{2} \mathrm{O}(30 \mathrm{mg} ; 150 \mu \mathrm{mol}$ ) were added. The vessel was purged with argon and transferred to an argon-filled glovebox where (R)-3,4,5-MeO-MeO-BIPHEP (L7, $155.6 \mathrm{mg} ; 165 \mu \mathrm{mol}$ ) were added. The vessel was sealed and removed from the glove box. It was then connected to a Schlenk line and degassed toluene $(1.75 \mathrm{~mL})$, followed by degassed TPGS-750-M 2 wt \% / $\mathrm{H}_{2} \mathrm{O}(25 \mathrm{~mL})$, were added with rapid stirring, forming an emulsion. The emulsion was stirred at $\mathrm{rt}$ for $90 \mathrm{~min}$. The reaction vessel was then submerged in an ice bath and allowed to stir for a further $10 \mathrm{~min}$. PMHS was then added in five portions (360 $\mu \mathrm{L}$ per portion, $1.8 \mathrm{~mL}$ total; 6 eq. total) with $30 \mathrm{~min}$ in between each addition. After the final addition, the Schlenk tube was sealed and stirred on ice for a further $30 \mathrm{~min}$. The ice bath was then removed, and the reaction was allowed to warm and stir at rt for $18 \mathrm{~h}$. The seal was then slowly released, which allowed a high pressure of hydrogen to escape. The reaction mixture was filtered and the recovered solid was suspended in EtOAc, deposited onto silica, and purified by flash chromatography using a Biotage auto-flash chromatography system with a gradient starting at 0\% EtOAc: $100 \%$ hexanes and ending at 25\% EtOAc: $75 \%$ hexanes

over 25 column volumes. The fractions containing product were pooled and stripped of solvent under vacuum to give $710 \mathrm{mg}$ of $(R)$-2-(1-hydroxyethyl)-6-methoxynaphthalene (1) yield 70\%). Chiral HPLC analysis was performed with a Chiralpak OD-H column with an isocratic eluent of 95:5 hexanes:isopropanol at $1 \mathrm{~mL} / \mathrm{min}$, with monitoring at $210 \mathrm{~nm}$. The observed ee was $96 \%$. 
HPLC analysis: large-scale asymmetric reduction product<smiles>COc1ccc2cc(C(C)O)ccc2c1</smiles>

$(R)-\mathbf{1 b}: 96 \%$ ee

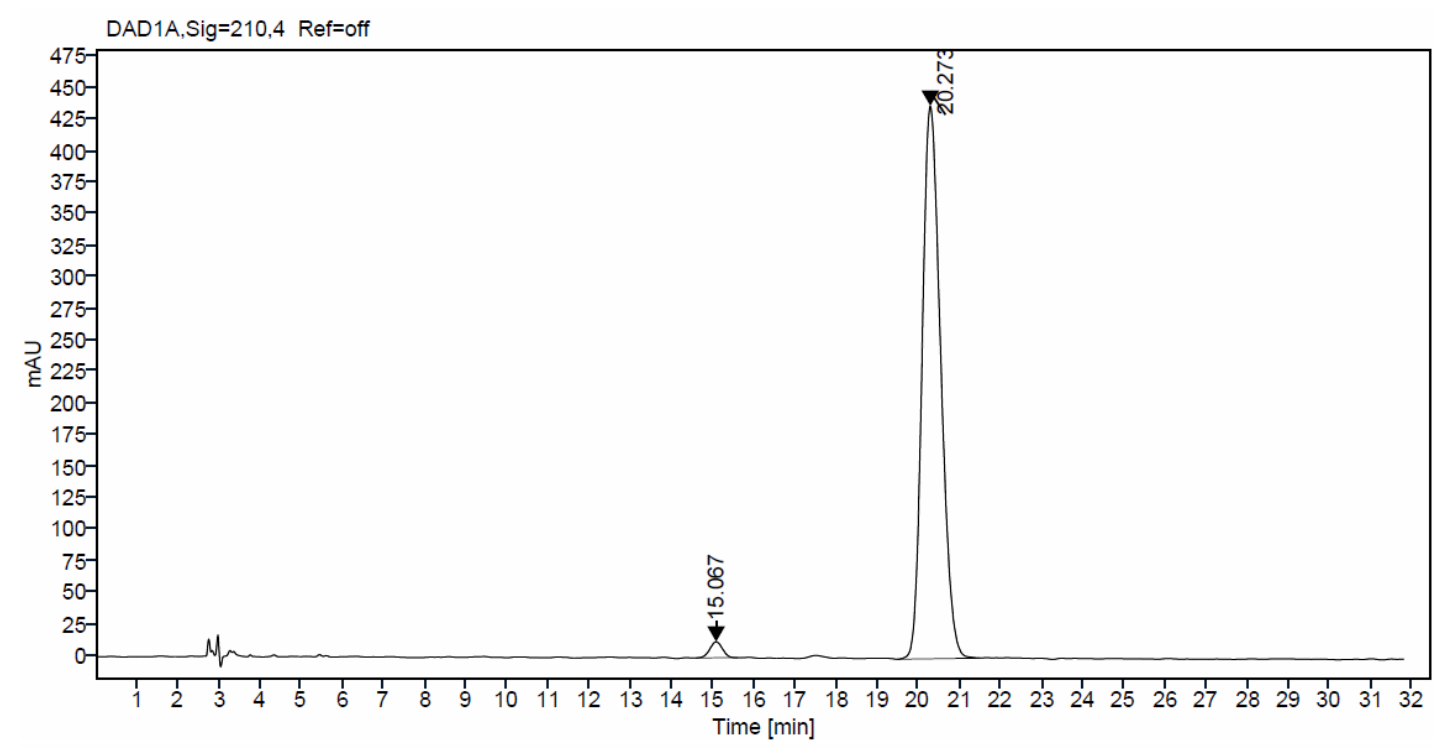

Single Injection Report

Agilent Technologies

\begin{tabular}{|c|c|c|}
\hline Signal: & $A D 1 A, S i g=210,4$ & 4 Ref=off \\
\hline RT [min] & Area & Area $\%$ \\
\hline 15.067 & 269.3585 & 1.9307 \\
\hline 20.273 & 13682.1242 & 98.0693 \\
\hline Sum & 13951.4827 & \\
\hline
\end{tabular}




\subsection{1-pot, 2-step reaction}

Asymmetric reduction of 2-acetyl-6-bromopyridine (16a) was set up on a $2 \mathrm{~mL}, 0.2 \mathrm{M}$ scale (80 mg ketone, $400 \mu \mathrm{mol}$ ) in a 2-dram vial using Method B with L 7. After reacting overnight, TLC analysis indicating almost quantitative conversion. The reaction was quenched by the slow addition of $212.3 \mathrm{mg} \mathrm{K}_{3} \mathrm{PO}_{4}(1 \mathrm{mmol}, 2.5$ equiv) to the reaction mixture with rapid stirring, resulting in the evolution of gas. After the bubbling subsided, 4-fluoro-2methylphenylboronic acid (61.6 mg, $400 \mu \mathrm{mol}, 1$ equiv) and $\mathrm{Pd}(\mathrm{dtbpf}) \mathrm{Cl}_{2}$ (5.2 mg, $8 \mu \mathrm{mol}, 2$ mol \%) were added under argon. The reaction vessel was sealed and stirred rapidly at rt for $18 \mathrm{~h}$. The reaction mixture was then extracted with $3 \times 4$ mL EtOAc. The extracts were dried over anhydrous $\mathrm{Na}_{2} \mathrm{SO}_{4}$, evaporated under vacuum onto Celite, and purified by flash chromatography. Compound $\mathbf{1 8 b}$ was obtained as an oil, $72.2 \mathrm{mg}$, 78\%. Chiral HPLC analysis was performed with a Chiralpak AD-H column with an isocratic eluent of 95:5 hexanes:IPA at $1 \mathrm{~mL} / \mathrm{min}$, with monitoring at $240 \mathrm{~nm}$. The observed ee was $93 \%$. 
HPLC analysis: racemic sec-alcohol standard<smiles>Cc1cc(F)ccc1-c1cccc(C(C)O)n1</smiles>

rac-18b

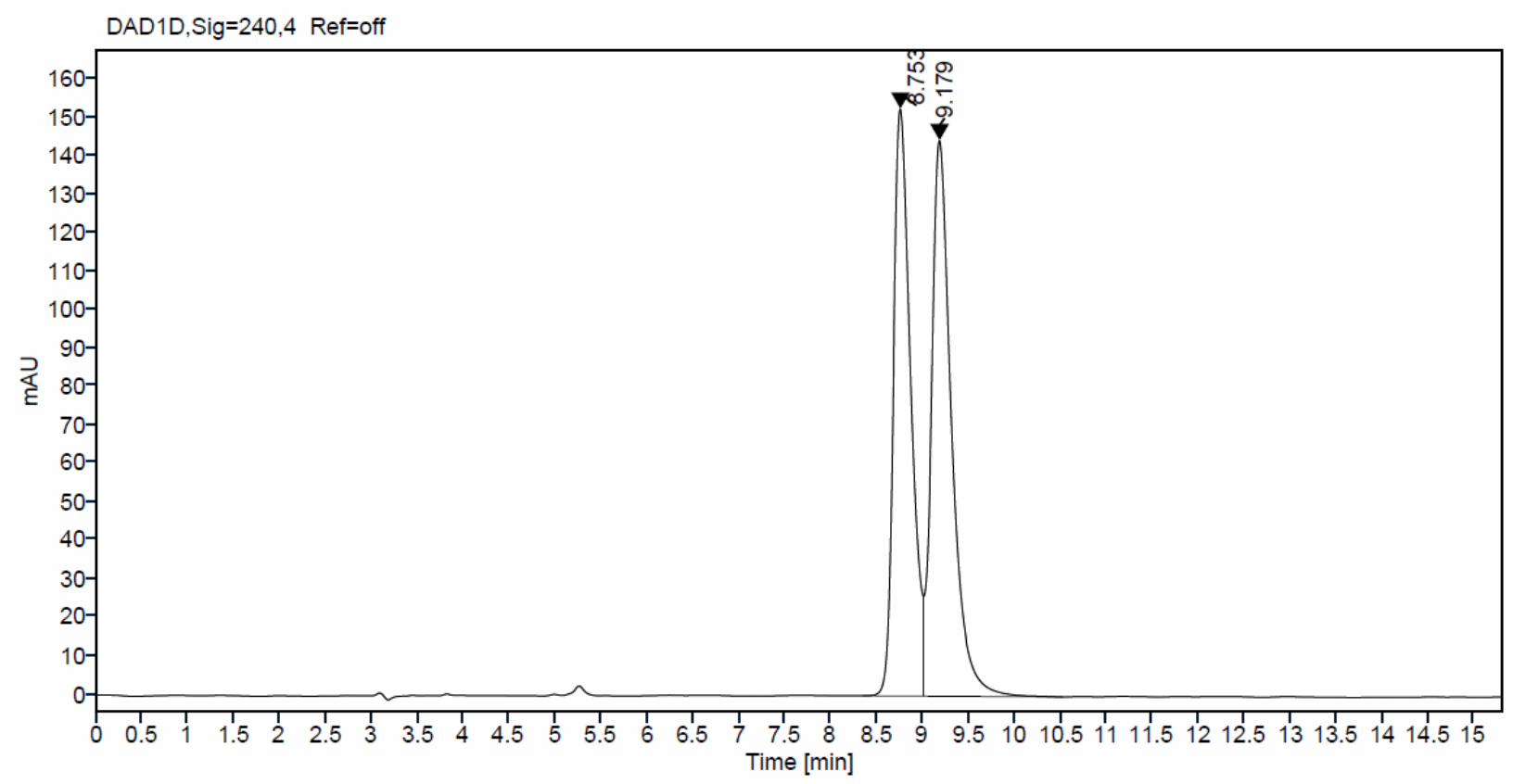

\section{Single Injection Report}

\begin{tabular}{|c|c|c|}
\hline Signal: & DAD1D,Sig $=240,4$ & t Ref $=$ off \\
\hline RT [min] & Area & Area $\%$ \\
\hline 8.753 & 2000.4961 & 47.7651 \\
\hline 9.179 & 2187.7010 & 52.2349 \\
\hline Sum & 4188.1971 & \\
\hline
\end{tabular}


HPLC analysis: 1-pot, 2-step reaction product<smiles>Cc1cc(F)ccc1-c1cccc(C(C)O)n1</smiles>

$(R)-\mathbf{1 8 b}$ : 93\% ee

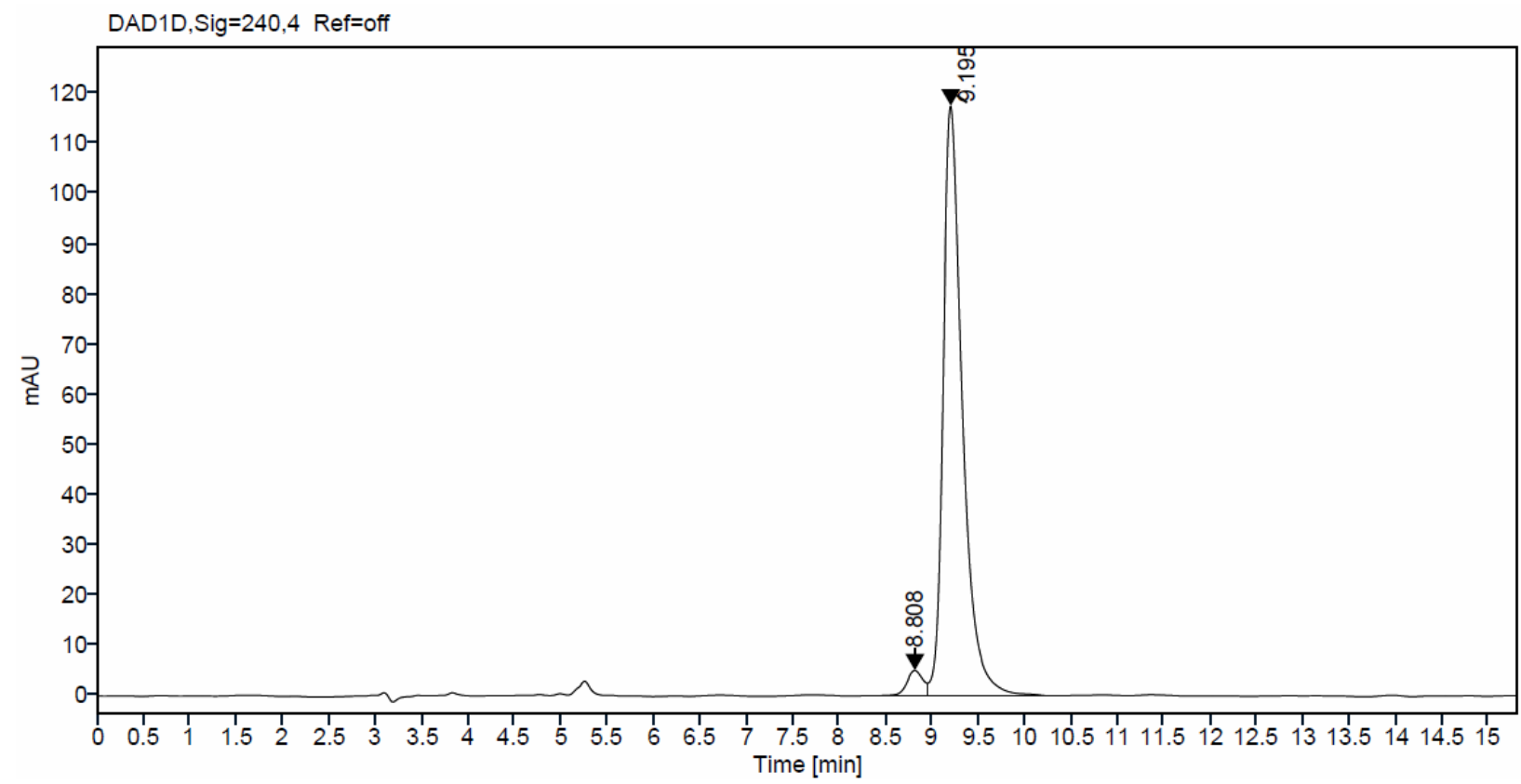

\section{Single Injection Report}

\begin{tabular}{rrr}
\multicolumn{1}{l}{$\begin{array}{l}\text { Signal: } \\
\text { RT [min] }\end{array}$} & AAD1D, Sig=240,4 & Ref $=$ off \\
8.808 & 61.4178 & Area $\%$ \\
9.195 & 1710.3581 & 3.4665 \\
Sum & 1771.7760 &
\end{tabular}




\subsection{Medium/catalyst recycling study and E factor calculation}

A recycling experiment was designed with substrate $6^{\prime}$-methoxy-2'-acetonaphthone (1a), which is a solid and gives a solid alcohol product (1b). The reaction was performed on a 2 $\mathrm{mL}, 0.2 \mathrm{M}$ scale $(80.1 \mathrm{mg}$ ketone, $400 \mu \mathrm{mol}$ ) in a 2 -dram vial. The initial reaction was set up using Method B. After reacting overnight, the fluoride quench was not performed. Instead, the mixture was carefully filtered under argon into a new 2-dram vial, and the solid was washed with $2 \times 125 \mu \mathrm{L}$ water. The stir bar, which had a small amount of white solid on it, was transferred directly from the first vial to the second without washing. The filtered solid, which consists of the unreacted starting material, product, and oxidized PMHS, was dried by pulling air through the filter for several hours.

The first recycling was set up by Method B using the recovered reaction medium as the stock solution. No additional catalyst was added. After reacting overnight, a very small sample was taken for TLC analysis, which showed the successful formation of alcohol product. This indicates that at least some of the copper catalyst is not lost by filtration. The first recycling reaction was filtered exactly as in the initial reaction.

The second recycling was set up and filtered exactly as in the first recycling.

Purification was performed by suspending the isolated white solids in EtOAc, depositing onto Celite, and separating by flash chromatography.

\section{E factor calculation: initial reaction}

After filtration, a white powder was obtained. From this solid, $60.6 \mathrm{mg}$ of product was isolated, corresponding to a yield of $75 \%$. The remainder of the filtered solid is assumed to be unreacted starting material (SM) and spent PMHS. The reaction medium, which includes the aqueous surfactant solution, toluene, catalyst complex, and the water used to wash the solid, were recycled.

$m(\mathrm{X})=$ mass of component $\mathrm{X}$

$\rho(\mathrm{X})=$ density of component $\mathrm{X}$

$V(\mathrm{X})=$ volume of component $\mathrm{X}$

$m(\mathrm{PMHS})=\rho(\mathrm{PMHS}) \cdot V(\mathrm{PMHS})=(1.006 \mathrm{~g} / \mathrm{mL}) \cdot(0.14 \mathrm{~mL})=140.8 \mathrm{mg}$

$m(\mathrm{SM}$ unreacted $)=(100 \%-$ product yield $) \cdot m(\mathrm{SM}$ initial $)=(1-0.75) \cdot 80.1 \mathrm{mg}=20 \mathrm{mg}$

$m($ solid waste $)=m($ PMHS $)+m($ SM unreacted $)=160.8 \mathrm{mg}$

$160.8 \mathrm{mg}$ solid waste $/ 60.6 \mathrm{mg}$ product, or an $\mathrm{E}$ Factor $=2.65$ 
HPLC analysis: initial reaction product<smiles>COc1ccc2cc([C@@H](C)O)ccc2c1</smiles>

$(R)-\mathbf{1 b}: 96 \%$ ee

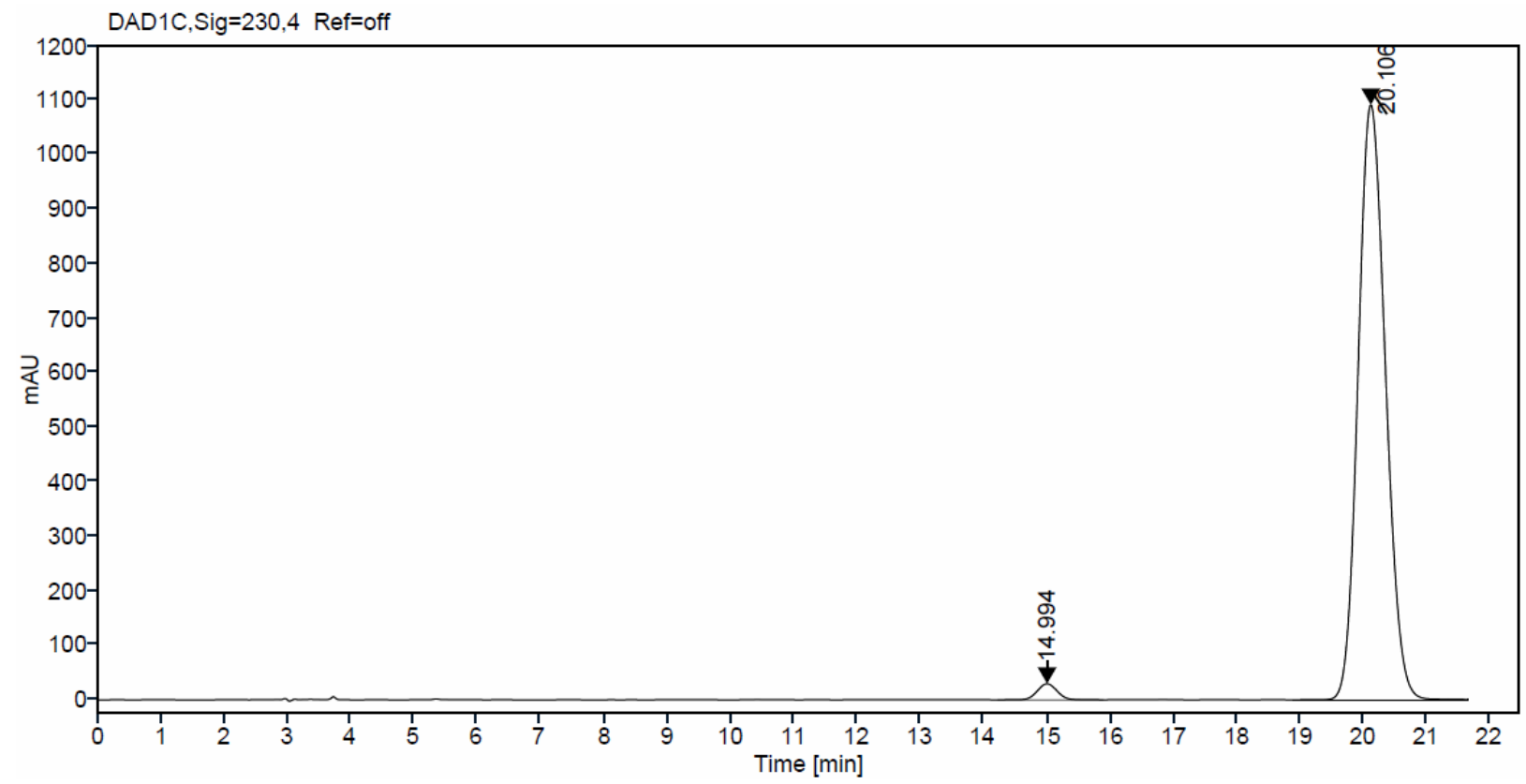

\section{Single Injection Report}

Agilent Technologies

\begin{tabular}{rrr}
\multicolumn{1}{l}{$\begin{array}{l}\text { Signal: } \\
\text { RT [min] }\end{array}$} & DAD1C,Sig=230,4 & Ref=off \\
14.994 & 650.2074 & Area\% \\
20.106 & 32740.9878 & 98.0528 \\
Sum & 33391.1952 &
\end{tabular}


After filtration, a white powder was obtained. From this solid, $63.9 \mathrm{mg}$ of product was isolated, corresponding to a yield of $79 \%$. The remainder of the filtered solid is assumed to be unreacted starting material and spent PMHS. The reaction medium, which includes the aqueous surfactant solution, toluene, catalyst complex, and the water used to wash the solid, was recycled.

$m(\mathrm{PMHS})=\rho(\mathrm{PMHS}) \cdot V(\mathrm{PMHS})=(1.006 \mathrm{~g} / \mathrm{mL}) \cdot(0.14 \mathrm{~mL})=140.8 \mathrm{mg}$

$m($ SM unreacted $)=(100 \%-$ product yield $) \cdot m($ SM initial $)=(1-0.79) \cdot 80.1 \mathrm{mg}=16.8 \mathrm{mg}$

$m($ solid waste $)=m($ PMHS $)+m($ SM unreacted $)=157.6 \mathrm{mg}$

$157.6 \mathrm{mg}$ solid waste/63.9 $\mathrm{mg}$ product, or an $\mathrm{E}$ Factor $=2.47$ 
HPLC analysis: $1^{\text {st }}$ recycling product<smiles>COc1ccc2cc(C(C)O)ccc2c1</smiles>

$(R)-1 \mathbf{b}: 96 \%$ ee

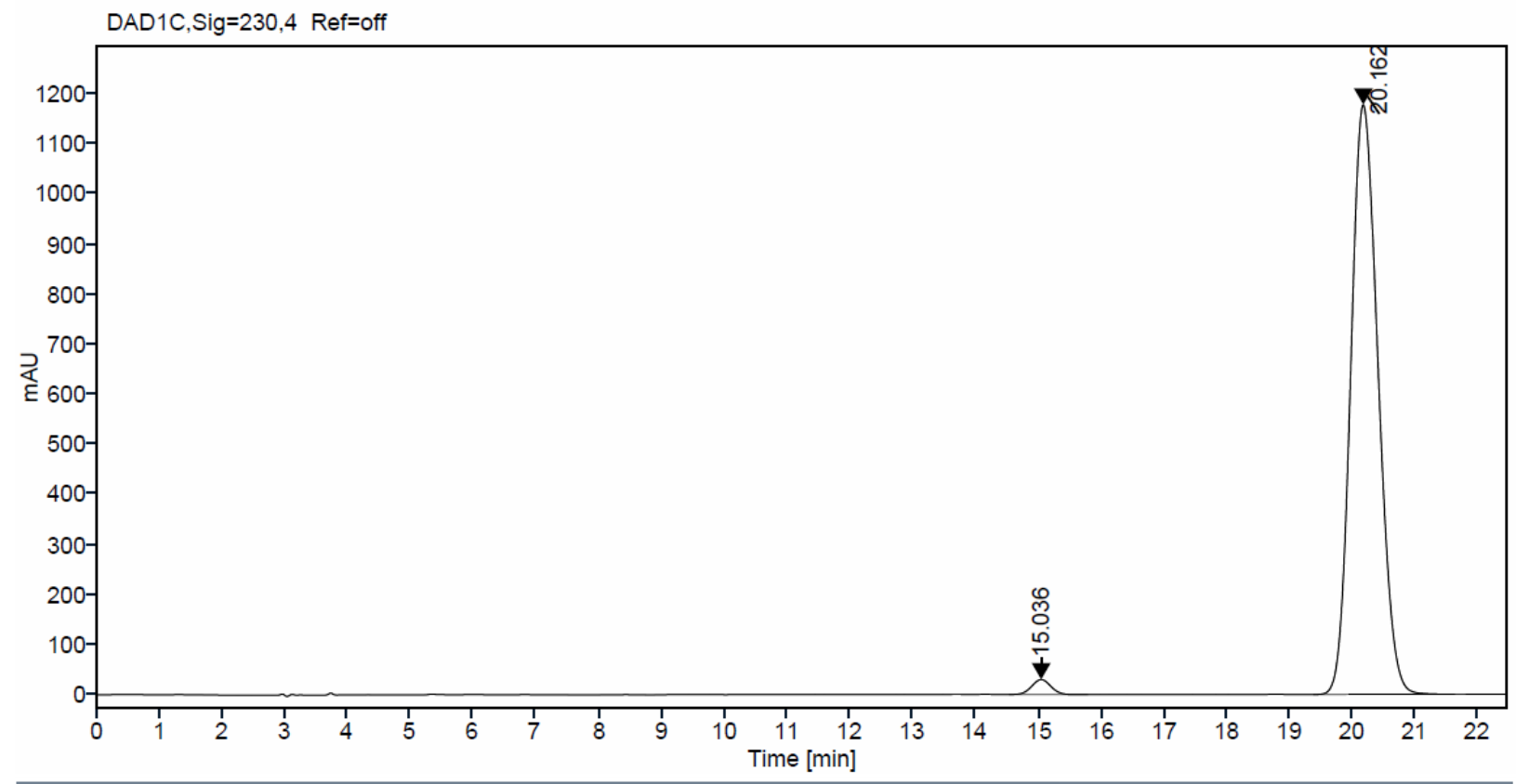

\section{Single Injection Report}

Agilent Technologies

\begin{tabular}{|c|c|c|}
\hline Signal: & DAD1C,, ig $=230,4$ & Ref $=$ off \\
\hline $\mathrm{RT}$ [min] & Area & Area $\%$ \\
\hline 15.036 & 642.1957 & 1.7808 \\
\hline 20.162 & 35420.7834 & 98.2192 \\
\hline Sum & 36062.9792 & \\
\hline
\end{tabular}


E factor calculation: $2^{\text {nd }}$ recycling

After filtration, a white powder was obtained. From this solid, $43.7 \mathrm{mg}$ of product was isolated, corresponding to a yield of $54 \%$. The remainder of the filtered solid is assumed to be unreacted starting material and spent PMHS. The reaction medium, which includes the aqueous surfactant solution, toluene, catalyst complex, and the water used to wash the solid, were considered as waste.

$m(\mathrm{PMHS})=\rho(\mathrm{PMHS}) \cdot V(\mathrm{PMHS})=(1.006 \mathrm{~g} / \mathrm{mL}) \cdot(0.14 \mathrm{~mL})=140.8 \mathrm{mg}$

$m($ SM unreacted $)=(100 \%-$ product yield $) \cdot m($ SM initial $)=(1-0.54) \cdot 80.1 \mathrm{mg}=36.8 \mathrm{mg}$

$m($ solid waste $)=m($ PMHS $)+m($ SM unreacted $)=177.6 \mathrm{mg}$

$m(\mathrm{PhMe})=\rho(\mathrm{PhMe}) \cdot V(\mathrm{PhMe})=(0.87 \mathrm{~g} / \mathrm{mL}) \cdot(0.16 \mathrm{~mL})=139.2 \mathrm{mg}$

$m\left(\mathrm{Cu}(\mathrm{OAc})_{2} \cdot \mathrm{H}_{2} \mathrm{O}\right)=2.4 \mathrm{mg}$

$m(3,4,5-\mathrm{MeO}-\mathrm{MeOBIPHEP})=12.5 \mathrm{mg}$

$m($ reagents $)=177.6 \mathrm{mg}+139.2 \mathrm{mg}+2.4 \mathrm{mg}+12.5 \mathrm{mg}=331.7 \mathrm{mg}$

$m$ (aqueous) $=2.0 \mathrm{~g}$ TPGS solution $+3 \cdot(0.25 \mathrm{~g}$ water wash $)=2.75 \mathrm{~g}$

$331.7 \mathrm{mg}$ reagent waste $/ 43.7 \mathrm{mg}$ product, or an $\mathrm{E}$ Factor $=7.59$ (not including water)

$3081.7 \mathrm{mg}$ waste $/ 43.7 \mathrm{mg}$ product, or an E Factor $=70.5$ (all waste components) 
HPLC analysis: $2^{\text {nd }}$ recycling product<smiles>COc1ccc2cc(C(C)O)ccc2c1</smiles>

(R)-1b: 96\% ee

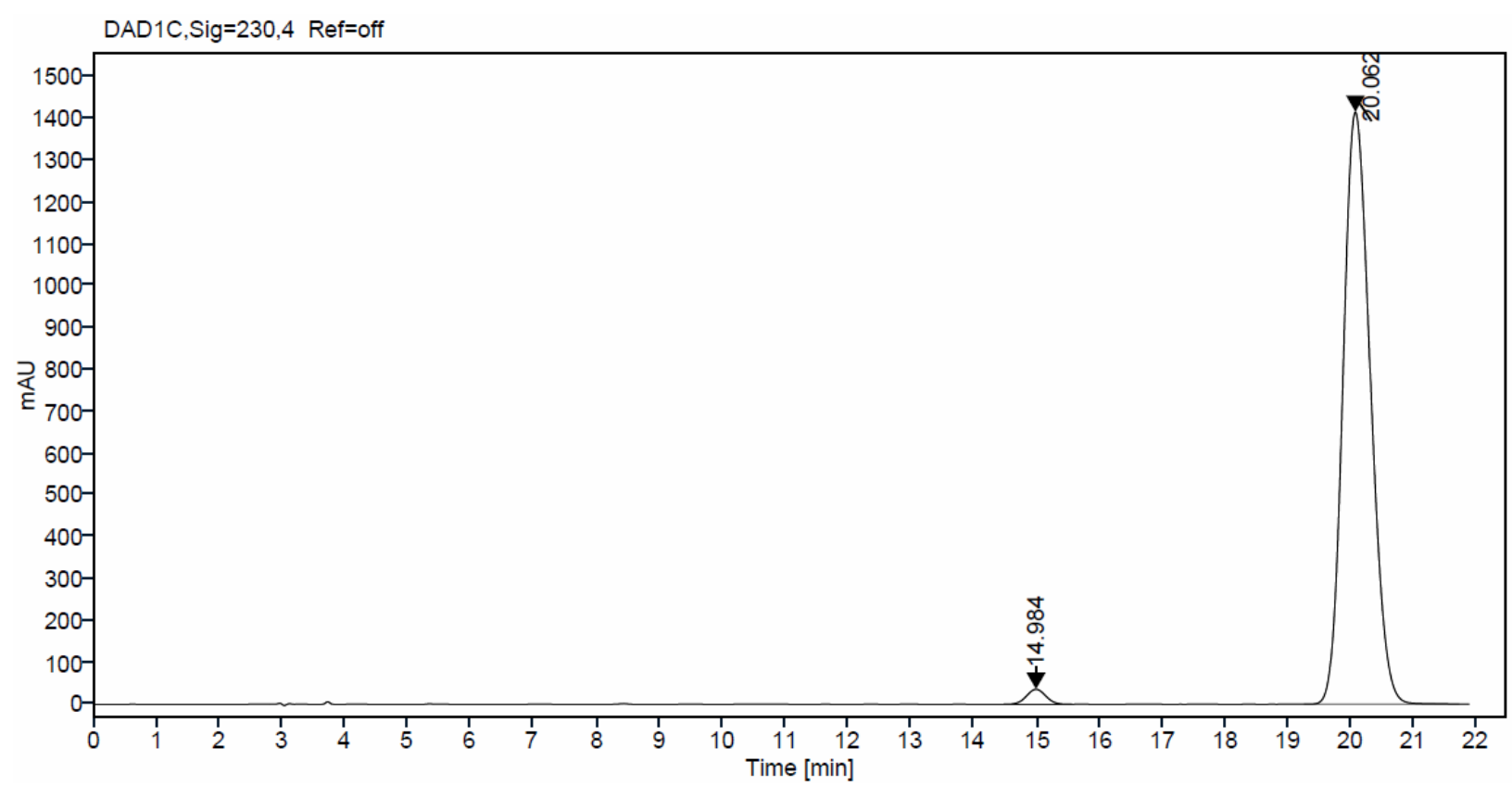

\section{Single Injection Report}

Agilent Technologies

\begin{tabular}{rrr}
\multicolumn{1}{l}{$\begin{array}{l}\text { Signal: } \\
\text { RT [min] }\end{array}$} & $\begin{array}{r}\text { DAD1C, Sig }=230,4 \\
\text { Ref }=\text { off } \\
\text { Area }\end{array}$ & Area $\%$ \\
14.984 & 771.3916 & 1.7770 \\
20.062 & 42638.7892 & 98.2230 \\
Sum & 43410.1807 &
\end{tabular}




\subsection{Determination of product absolute configuration}

An authentic sample of $(R)$-1-phenylethanol was purchased from MilliporeSigma (catalog number 685828). Product $\mathbf{2 b}$ was prepared according to Method A with $(R)-\mathbf{L} 7$ (see product characterization for details) and analyzed by chiral HPLC (Chiralpak OJ-H column, hexane: isopropanol $=95 / 5$; flow rate $=1.0 \mathrm{~mL} / \mathrm{min}$; UV detection at $210 \mathrm{~nm}$ ). By comparison of the chromatograms of $\mathbf{2 b}$, rac-1-phenylethanol, and authentic $(R)$-1-phenylethanol, it was determined that the major product of the asymmetric reduction of $\mathbf{2 a}$ with $(R)$-L7 was $(R)$ 1-phenylethanol.

HPLC analysis of 1-phenylethanol samples<smiles>CC(O)c1ccccc1</smiles>

rac-1-phenylethanol: $0 \%$ ee

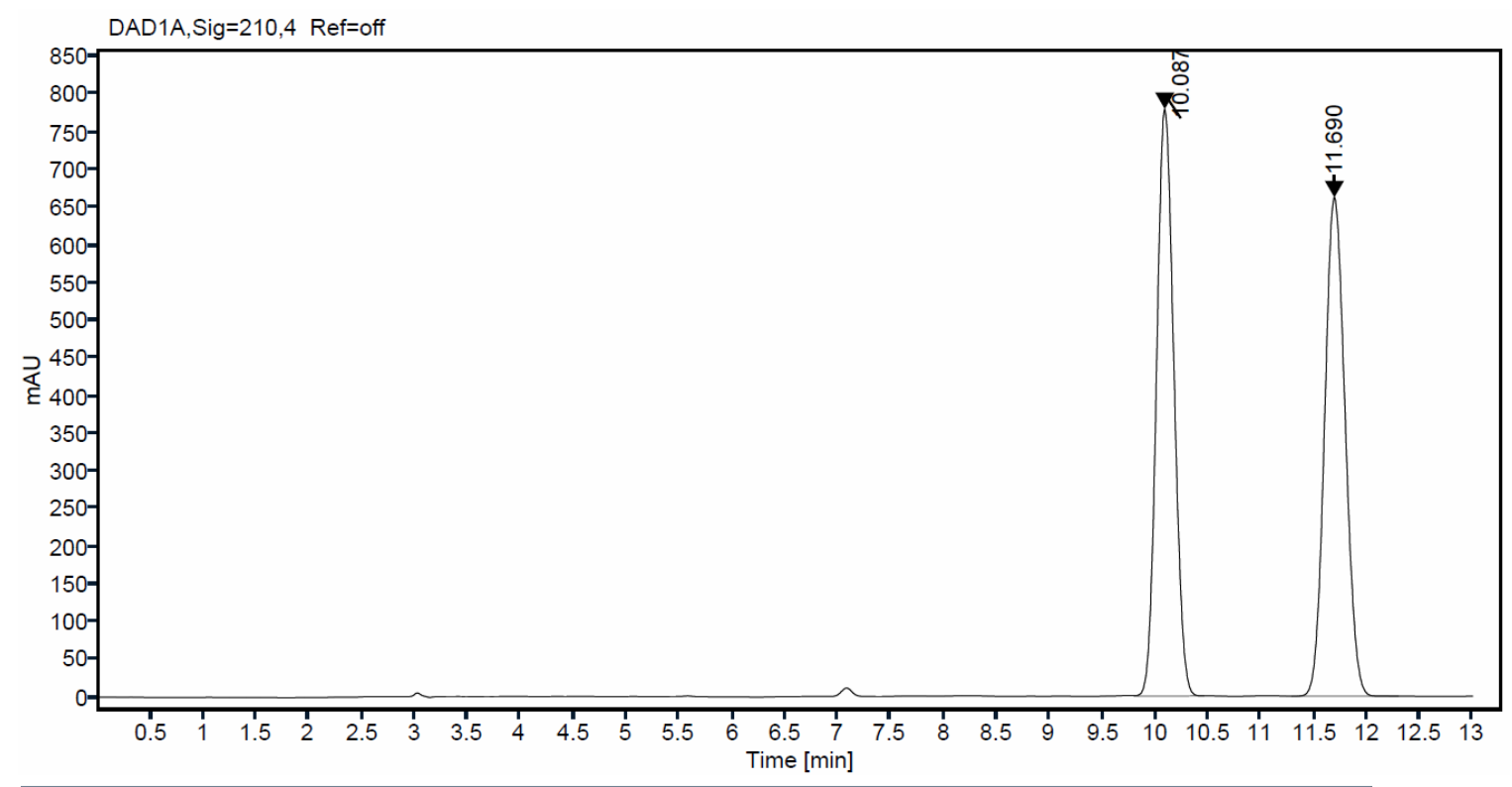

Single Injection Report

Agilent Technologies

\begin{tabular}{|c|c|c|}
\hline Signal: & $\mathrm{DAD} 1 \mathrm{~A}, \mathrm{Sig}=210,4$ & Ref $=$ off \\
\hline $\mathrm{RT}$ [min] & Area & Area $\%$ \\
\hline 10.087 & 8873.5689 & 49.9034 \\
\hline 11.690 & 8907.9154 & 50.096 \\
\hline Sun & 17781.4844 & \\
\hline
\end{tabular}


<smiles>CC(O)c1ccccc1</smiles>

commercial $(R)$-1-phenylethanol: $100 \%$ ee

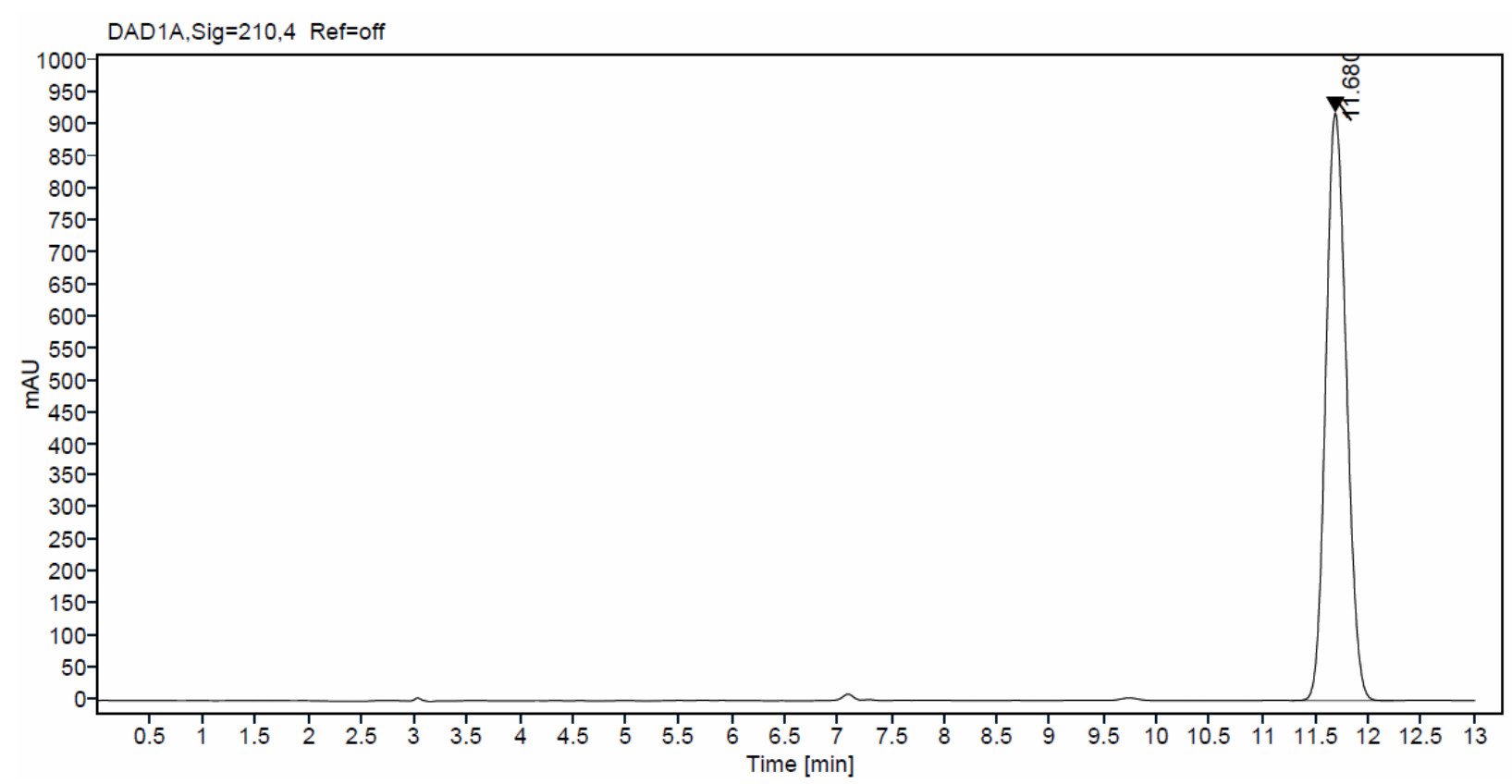

\section{Single Injection Report}

\section{Agilent Technologies}

\begin{tabular}{rrr}
\multicolumn{1}{l}{$\begin{array}{l}\text { Signal: } \\
\text { RT [min] }\end{array}$} & DAD1A,Sig=210,4 Ref $=$ off \\
11.680 & 12409.8298 & 100.0000 \\
Sum & 12409.8298 &
\end{tabular}


<smiles>C[C@H](O)c1ccccc1</smiles>

reaction product $(R)-2 \mathbf{b}: 94 \%$ ee

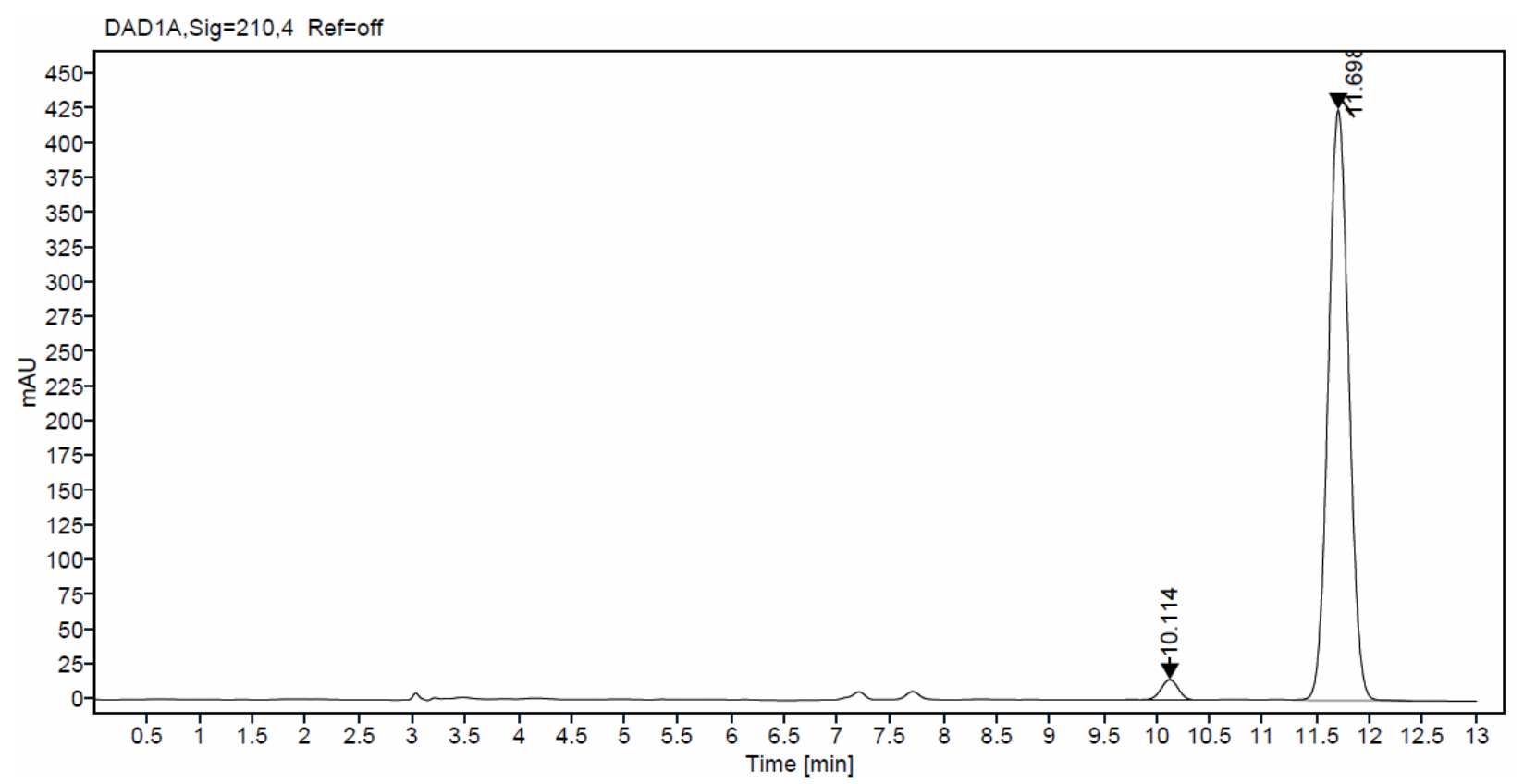

\section{Single Injection Report}

\section{Agilent Technologies}

\begin{tabular}{rrr}
\multicolumn{1}{l}{$\begin{array}{l}\text { Signal: } \\
\text { RT [min] }\end{array}$} & DAD1A, Sig=210,4 & Ref=off \\
10.114 & 166.7388 & Area $\%$ \\
11.698 & 5693.8953 & 2.8451 \\
Sum & 5860.6341 &
\end{tabular}




\section{Synthesis and characterization of starting materials}

Compounds 1a, 2a, 3a, 4a, 6a, 7a, 11a, 16a, 20a, and 24a are all commercially available. Compounds 5a, 13a, 15a, and 21a were synthesized according to a published protocol for aqueous Suzuki-Miyaura couplings. ${ }^{3}$ Compounds $8 \mathbf{a}$ and $9 \mathbf{a}$ were synthesized according to a published protocol for aqueous Sonogashira couplings. ${ }^{4}$ Compound 12a was synthesized according to a published protocol for aqueous Heck couplings. ${ }^{5}$ Compounds $\mathbf{1 7 a}^{6}$ and $\mathbf{2 2} \mathbf{a}^{7}$ were prepared according to unmodified literature procedures. The identities of all synthesized starting materials were verified by comparison with published spectra.

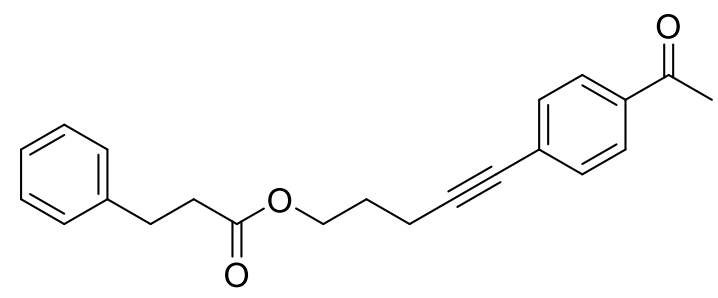

10a

Compound 10a was synthesized in two steps by an aqueous Sonogashira reaction followed by Steglich esterification. The initial Sonogashira reaction between $4^{\prime}$-iodoacetophenone and pent-4-yn-1-ol was performed in water according to a published protocol. ${ }^{4}$ Steglich esterification was then performed with the alcohol product $(1.5$ eq., $1.5 \mathrm{M})$ and 3phenylpropanoic acid (1 eq., $1 \mathrm{M}$ ) in anhydrous DCM with DCC (1.1 eq.) and DMAP (6 mol $\%)$.

${ }^{1} \mathrm{H}$ NMR $\left(600 \mathrm{MHz}, \mathrm{CDCl}_{3}\right) \delta: 7.86(\mathrm{~d}, J=8.5 \mathrm{~Hz}, 2 \mathrm{H}), 7.44(\mathrm{~d}, J=8.4 \mathrm{~Hz}, 2 \mathrm{H}), 7.27(\mathrm{t}, J=7.5$ $\mathrm{Hz}, 2 \mathrm{H}), 7.18(\mathrm{~m}, 3 \mathrm{H}), 4.21(\mathrm{t}, J=6.3 \mathrm{~Hz}, 2 \mathrm{H}), 2.94(\mathrm{t}, J=7.8 \mathrm{~Hz}, 2 \mathrm{H}), 2.63(\mathrm{t}, J=7.8 \mathrm{~Hz}, 2 \mathrm{H})$, $2.57(\mathrm{~s}, 3 \mathrm{H}), 2.46(\mathrm{t}, J=7.0 \mathrm{~Hz}, 2 \mathrm{H}), 1.90(\mathrm{p}, J=6.7 \mathrm{~Hz}, 2 \mathrm{H})$.

${ }^{13} \mathrm{C}$ NMR $\left(151 \mathrm{MHz}, \mathrm{CDCl}_{3}\right) \delta: 197.4,172.9,140.4,135.9,131.7,128.7,128.5,128.3,128.2$, $126.3,92.5,80.8,63.1,35.9,31.0,27.6,26.6,16.3$.

HRMS (ESI): $m / z$ calculated for $\left[\mathrm{C}_{22} \mathrm{H}_{22} \mathrm{O}_{3} \mathrm{Na}\right]^{+}: 357.1467 ;[\mathrm{M}+\mathrm{Na}]^{+}$found: 357.1465 . 
<smiles>CCCCCC(=O)c1ccc(Sc2ccccc2)cc1</smiles>

Compound 14a was synthesized by a reported Friedel-Crafts acylation protocol ${ }^{8}$ with diphenyl sulfide and lauroyl chloride.

${ }^{1} \mathrm{H}$ NMR (600 MHz, $\left.\mathrm{CDCl}_{3}\right) \delta: 7.80(\mathrm{~d}, J=8.5 \mathrm{~Hz}, 2 \mathrm{H}), 7.48(\mathrm{dd}, J=7.6,1.9 \mathrm{~Hz}, 2 \mathrm{H}), 7.36-7.39$ $(\mathrm{m}, 3 \mathrm{H}), 7.20(\mathrm{~d}, J=8.5 \mathrm{~Hz}, 2 \mathrm{H}), 2.87(\mathrm{t}, J=7.4 \mathrm{~Hz}, 2 \mathrm{H}), 1.69(\mathrm{p}, J=7.5 \mathrm{~Hz}, 2 \mathrm{H}), 1.23-1.34(\mathrm{~m}$, $16 \mathrm{H}), 0.86(\mathrm{t}, J=7.0 \mathrm{~Hz}, 3 \mathrm{H})$.

${ }^{13} \mathrm{C}$ NMR $\left(151 \mathrm{MHz}, \mathrm{CDCl}_{3}\right) \delta: 199.6,144.4,134.5,133.8,132.3,129.7,128.7,128.7$ (2), 127.6, $38.5,31.9,29.6,29.6,29.5,29.5$ (2), 29.4, 29.3, 24.5, 22.7, 14.1.

HRMS (ESI): m/z calculated for $\left[\mathrm{C}_{24} \mathrm{H}_{32} \mathrm{OS}\right]^{+}: 368.2174 ;[\mathrm{M}]^{+}$found: 368.2169 .<smiles>CC(=O)c1cccc(-c2ccc(F)cc2C)n1</smiles>

Compound 18a was synthesized by Suzuki-Miyaura coupling of 2-acetyl-6-bromopyridine (1 mmol) and 2-methyl-4-fluorophenylboronic acid (1.2 mmol) with $\mathrm{Pd}(\mathrm{dppf}) \mathrm{Cl}_{2}(4 \mathrm{~mol} \%)$ and $\mathrm{K}_{2} \mathrm{CO}_{3}(2 \mathrm{mmol})$ in $\mathrm{DMF}$ at $130{ }^{\circ} \mathrm{C}$.

${ }^{1} \mathrm{H}$ NMR (500 MHz, $\left.\mathrm{CDCl}_{3}\right) \delta: 8.01(\mathrm{dd}, J=7.8,1.0 \mathrm{~Hz}, 1 \mathrm{H}), 7.91(\mathrm{t}, J=7.8 \mathrm{~Hz}, 1 \mathrm{H}), 7.59(\mathrm{dd}, J$ = 7.7, $1.0 \mathrm{~Hz}, 1 \mathrm{H}), 7.45(\mathrm{dd}, J=8.4,5.9 \mathrm{~Hz}, 1 \mathrm{H}), 7.00-7.06(\mathrm{~m}, 1 \mathrm{H}), 2.75(\mathrm{~s}, 3 \mathrm{H}), 2.47(\mathrm{~s}, 3 \mathrm{H})$.

${ }^{13} \mathrm{C}$ NMR $\left(126 \mathrm{MHz} \mathrm{CDCl}_{3}\right) \delta: 200.4,163.8,161.8,158.4,153.0,138.9$ (d, $\left.J=8.3 \mathrm{~Hz}\right), 137.2$, $131.5(\mathrm{~d}, J=8.6 \mathrm{~Hz}), 127.3,119.4,117.7$ (d, $J=21.2 \mathrm{~Hz}), 112.9$ (d, $J=21.2 \mathrm{~Hz}), 25.9,20.8$.

HRMS (ESI): $m / z$ calculated for $\left[\mathrm{C}_{14} \mathrm{H}_{11} \mathrm{FNO}\right]^{+}: 228.0825 ;[\mathrm{M}-\mathrm{H}]^{+}$found: 228.0825 . 


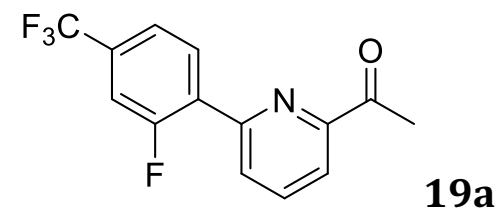

Compound 19a was synthesized by Suzuki-Miyaura coupling of 2-acetyl-6-bromopyridine $(1 \mathrm{mmol})$ and 2-fluoro-4-(trifluoromethyl)phenylboronic acid $(1.2 \mathrm{mmol})$ with $\mathrm{Pd}(\mathrm{dppf}) \mathrm{Cl}_{2}$ (4 mol \%) and $\mathrm{K}_{2} \mathrm{CO}_{3}(2 \mathrm{mmol})$ in DMF at $130{ }^{\circ} \mathrm{C}$.

${ }^{1} \mathrm{H}$ NMR $\left(500 \mathrm{MHz}, \mathrm{CDCl}_{3}\right) \delta: 8.29(\mathrm{t}, J=7.9 \mathrm{~Hz}, 1 \mathrm{H}), 8.04-8.07(\mathrm{~m}, 2 \mathrm{H}), 7.95(\mathrm{t}, J=7.8 \mathrm{~Hz}, 1 \mathrm{H})$, $7.59(\mathrm{~d}, J=7.5 \mathrm{~Hz}, 1 \mathrm{H}), 7.48(\mathrm{~d}, J=11.1 \mathrm{~Hz}, 1 \mathrm{H}), 5.30(\mathrm{~s}, 1 \mathrm{H}), 2.81(\mathrm{~s}, 3 \mathrm{H})$.

${ }^{13} \mathrm{C}$ NMR $\left(126 \mathrm{MHz}, \mathrm{CDCl}_{3}\right) \delta: 199.8,161.3,159.3,153.6,151.0(\mathrm{~d}, J=2.8 \mathrm{~Hz}), 137.7,132.7$, 131.9 (d, $J=3.1 \mathrm{~Hz}), 129.9,127.8$ (d, $J=10.7 \mathrm{~Hz}), 121.3-120.5(\mathrm{~m}), 120.8,113.9$ (dq, $J=26.7$, $3.9 \mathrm{~Hz}), 25.7$.

HRMS (ESI): $m / z$ calculated for $\left[\mathrm{C}_{14} \mathrm{H}_{9} \mathrm{~F}_{4} \mathrm{NO}\right]^{+}: 283.0620$; [M] $]^{+}$found: 283.0615 .<smiles>CCOC(=O)CCCC(=O)c1ccc(F)cc1</smiles>

Compound 23a was synthesized according to a modified literature procedure. ${ }^{9}$ Anhydrous $\mathrm{AlCl}_{3}(10.4 \mathrm{~g}, 78 \mathrm{mmol})$ and fluorobenzene $(12.5 \mathrm{~mL})$ were added to a $100 \mathrm{~mL}$ flask equipped with a stir bar. The mixture was stirred in an ice bath. A suspension of glutaric anhydride $(4.2 \mathrm{~g}, 35.8 \mathrm{mmol}$ ) in fluorobenzene $(17.5 \mathrm{~mL})$ was added dropwise (for a total of $30 \mathrm{~mL}$ fluorobenzene, $312 \mathrm{mmol}$ ). The stirred mixture took on a red color as the reaction progressed. After $2 \mathrm{~h}$, excess fluorobenzene was removed under vacuum. The solid residue was placed in an ice bath and EtOH $(40 \mathrm{~mL})$ was added slowly with stirring. (Warning: the addition of $\mathrm{EtOH}$ to anhydrous $\mathrm{AlCl}_{3}$ is dangerously exothermic.) The mixture was heated at $70{ }^{\circ} \mathrm{C}$ overnight. The $\mathrm{EtOH}$ was removed under vacuum and the solid was suspended in EtOAc. Sat. $\mathrm{NaHCO}_{3}$ was added slowly, causing the aluminum to precipitate. The heterogeneous mixture was filtered and washed with EtOAc. The organic phase was reduced in volume under vacuum and purified by flash chromatography. The product partially coeluted with at least one side-product; only fractions containing the target ester were pooled and stripped of solvent, giving $398 \mathrm{mg}$ of product (1.67 mmol, 4.7\%).

${ }^{1} \mathrm{H} \mathrm{NMR}\left(500 \mathrm{MHz}, \mathrm{CDCl}_{3}\right) \delta: 7.99(\mathrm{~m}, 2 \mathrm{H}), 7.12(\mathrm{~m}, 2 \mathrm{H}), 4.14(\mathrm{q}, J=7.1 \mathrm{~Hz}, 2 \mathrm{H}), 3.02(\mathrm{t}, J=7.1$ $\mathrm{Hz}, 2 \mathrm{H}), 2.42(\mathrm{t}, J=7.2 \mathrm{~Hz}, 2 \mathrm{H}), 2.06(\mathrm{p}, J=7.2 \mathrm{~Hz}, 2 \mathrm{H}), 1.25(\mathrm{t}, J=7.1 \mathrm{~Hz}, 3 \mathrm{H})$.

${ }^{13} \mathrm{C}$ NMR $\left(126 \mathrm{MHz}, \mathrm{CDCl}_{3}\right) \delta: 197.8,173.2,166.8,164.7,133.3$ (d, $\left.J=3.1 \mathrm{~Hz}\right), 130.7$ (d, $J=9.3$ $\mathrm{Hz}), 115.7(\mathrm{~d}, J=21.8 \mathrm{~Hz}), 60.4,37.4,33.3,19.4,14.2$.

HRMS (ESI): $m / z$ calculated for $\left[\mathrm{C}_{13} \mathrm{H}_{15} \mathrm{FO}_{3} \mathrm{Na}\right]^{+}: 261.0903$; [M] found: 263.0899 . 


\section{Characterization of products}<smiles>COc1ccc2cc([C@@H](C)O)ccc2c1</smiles>

$1 \mathbf{b}$

Synthesized using Method A.

${ }^{1} \mathrm{H}$ NMR $\left(500 \mathrm{MHz}, \mathrm{CDCl}_{3}\right) \delta: 7.74(\mathrm{t}, J=7.1 \mathrm{~Hz}, 3 \mathrm{H}), 7.47-7.49(\mathrm{~m}, 1 \mathrm{H}), 7.14-7.17(\mathrm{~m}, 2 \mathrm{H})$, $5.05(\mathrm{q}, J=6.4 \mathrm{~Hz}, 1 \mathrm{H}), 3.94(\mathrm{~s}, 3 \mathrm{H}), 1.96(\mathrm{~s}, 1 \mathrm{H}), 1.59(\mathrm{~d}, J=6.5 \mathrm{~Hz}, 3 \mathrm{H})$.

${ }^{13} \mathrm{C}$ NMR $\left(126 \mathrm{MHz} \mathrm{CDCl}_{3}\right) \delta: 157.6,140.9,134.0,129.4,128.7,127.2,124.4,123.8,118.9$, $105.7,70.5,55.3,25.1$.

Yield: $91 \%(0.0183 \mathrm{~g})$

$\mathrm{R}_{\mathrm{f}}:$ hex/EtOAc (1/0.15: 13\%), 0.25

ICP-MS: trace Cu: $70.290 \pm 1.177 \mu \mathrm{g} / \mathrm{g}$ (sample weight; $0.22 \mathrm{mg}$ )

The ee was determined by HPLC analysis on Chiralpak OD-H column, hexane:IPA = 95/5; flow rate $=0.8 \mathrm{~mL} / \mathrm{min}$; UV detection at $210 \mathrm{~nm} ; \mathrm{t}_{\mathrm{R}}(S)=20.05 \mathrm{~min}(\operatorname{minor}), \mathrm{t}_{\mathrm{R}}(R)=26.60 \mathrm{~min}$ (major), ee $=96 \%(R)$. HPLC chromatograms are shown below for the racemic standard (top) and enantioenriched product (bottom). 
$r a c-\mathbf{1 b}$

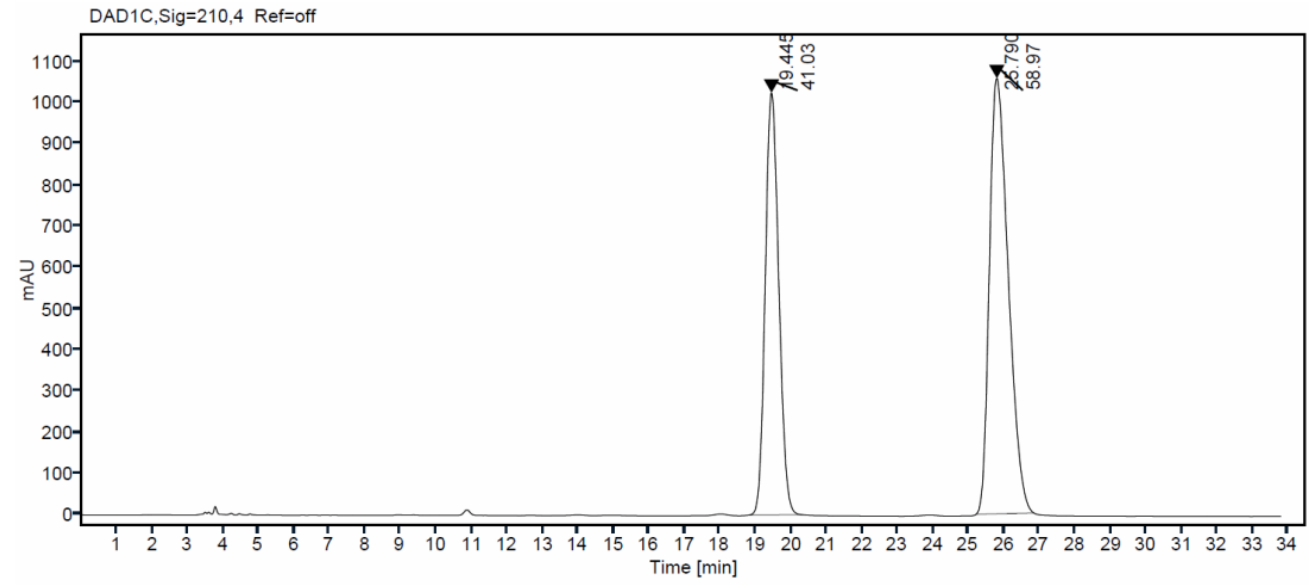

Single Injection Report

\section{Agilent Technologies}

Signal:

DAD1C, Sig=210,4 Ref=off

RT [min]

Area

Area \%

19.445

27115.1062

41.0319

25.790

38967.9345

58.9681

Sum

66083.0407

$(R)-\mathbf{1 b}$

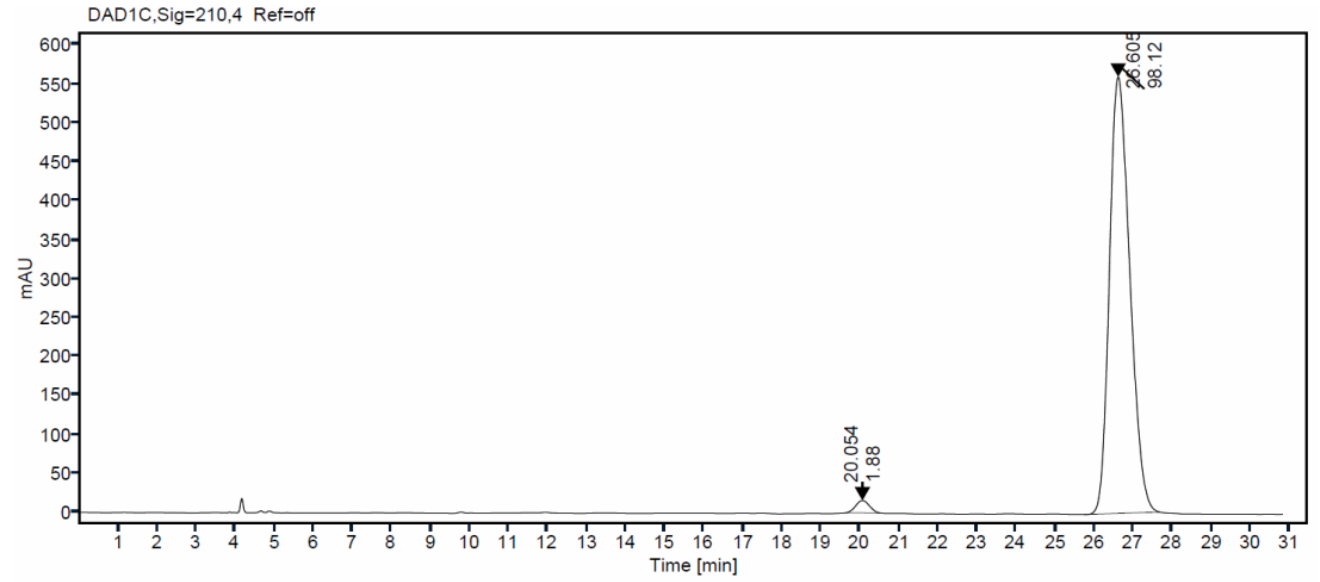

\section{Single Injection Report}

Signal: $\quad$ DAD1C, $\operatorname{Sig}=210,4$ Ref $=$ off

RT [min]

20.054

26.605

Sum

Area

390.4842

20358.3856

20748.8698
Area \%

1.8820

98.1180 
<smiles>C[C@H](O)c1ccccc1</smiles>

Prepared by Method A.

${ }^{1} \mathrm{H} \mathrm{NMR}\left(500 \mathrm{MHz} \mathrm{CDCl}_{3}\right) \delta: 7.36(\mathrm{~m}, 4 \mathrm{H}), 7.28(\mathrm{~m}, 1 \mathrm{H}), 4.90(\mathrm{q}, J=6.4 \mathrm{~Hz}, 1 \mathrm{H}), 1.50(\mathrm{~d}, J=$ $6.4 \mathrm{~Hz}, 3 \mathrm{H})$.

${ }^{13} \mathrm{C} \mathrm{NMR}\left(126 \mathrm{MHz}, \mathrm{CDCl}_{3}\right) \delta: 145.8,128.5,127.5,125.4,70.4,25.2$.

Yield: $75 \%$.

$\mathrm{R}_{\mathrm{f}}:$ hex/EtOAc (1/0.33: 25\%), 0.35

The enantiomeric excess was determined by HPLC analysis on Chiralpak OJ-H column, hexane:IPA $=95 / 5$; flow rate $=1.0 \mathrm{~mL} / \mathrm{min}$; $U V$ detection at $210 \mathrm{~nm} ; \mathrm{t}_{\mathrm{R}}(S)=10.11 \mathrm{~min}$ (minor), $\mathrm{t}_{\mathrm{R}}(R)=11.70$ min (major), ee $=94 \%(R)$. HPLC chromatograms are shown below for the racemic standard (top) and enantioenriched product (bottom). See section 3.6 of the SI for determination of absolute configuration. 
rac-2b

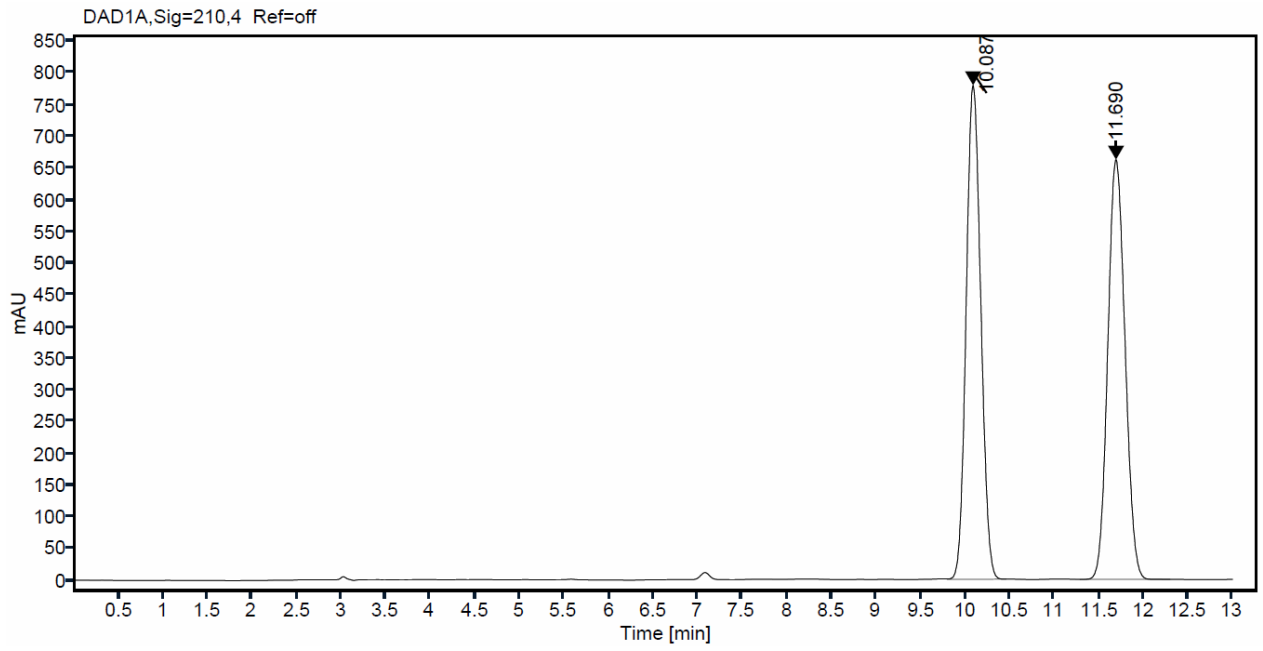

\section{Single Injection Report}

\section{Agilent Technologies}

\begin{tabular}{rrr}
\multicolumn{1}{l}{$\begin{array}{l}\text { Signal: } \\
\text { RT [min] }\end{array}$} & $\begin{array}{r}\text { DAD1A,Sig=210,4 } \\
\text { Ref=off }\end{array}$ \\
10.087 & 8873.5689 & Area $\%$ \\
11.690 & 8907.9154 & 50.0034 \\
Sum & 17781.4844 &
\end{tabular}

$(R)-\mathbf{2 b}$

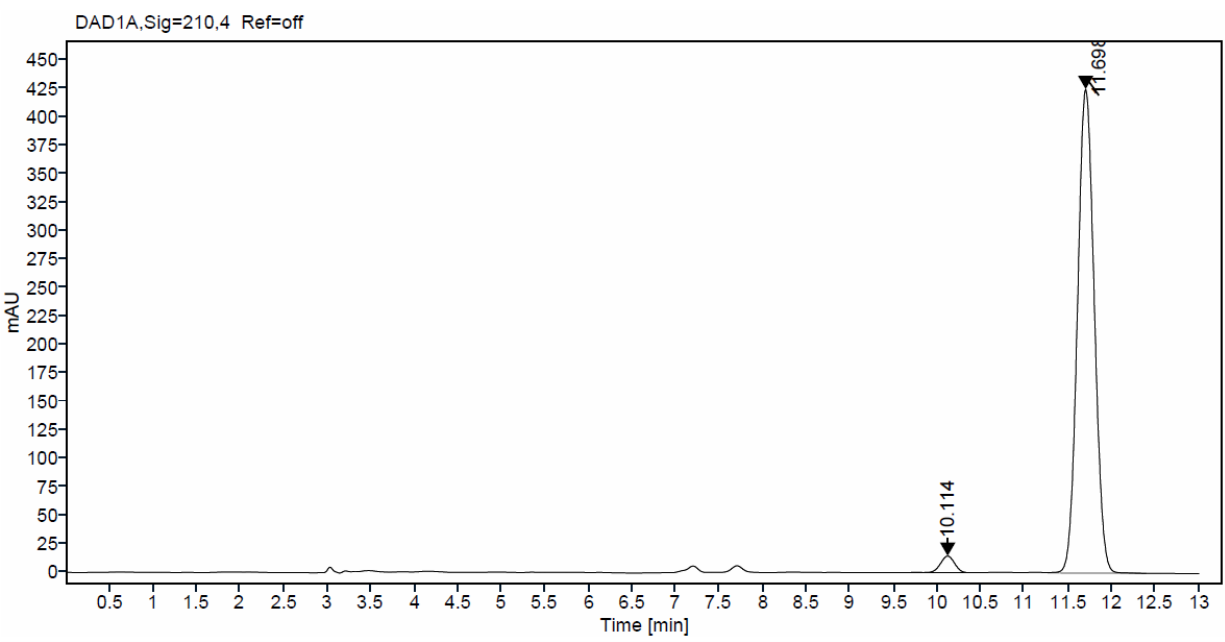

\section{Single Injection Report}

$\begin{array}{rrr}\text { Signal: } & \text { DAD1A, Sig=210,4 } & \text { Ref=off } \\ \text { RT [min] } & \text { Area } & \text { Area\% } \\ 10.114 & 166.7388 & 2.8451 \\ 11.698 & 5693.8953 & 97.1549 \\ \text { Sum } & 5860.6341 & \end{array}$


<smiles>Cc1ccc([C@@H](C)O)cc1</smiles>

Synthesized using Method A.

${ }^{1} \mathrm{H}$ NMR (500 MHz, $\left.\mathrm{CDCl}_{3}\right) \delta: 7.28(\mathrm{~d}, J=8.0 \mathrm{~Hz}, 2 \mathrm{H}), 7.18(\mathrm{~d}, J=7.9 \mathrm{~Hz}, 2 \mathrm{H}), 4.88(\mathrm{q}, J=6.3$ $\mathrm{Hz}, 1 \mathrm{H}), 2.37(\mathrm{~s}, 3 \mathrm{H}), 1.93(\mathrm{~s}, 1 \mathrm{H}), 1.50(\mathrm{~d}, J=6.5 \mathrm{~Hz}, 3 \mathrm{H})$.

${ }^{13} \mathrm{C}$ NMR (126 MHz, $\left.\mathrm{CDCl}_{3}\right)$ \&: 142.9, 137.2, 129.2, 125.4, 70.3, 25.1, 21.1.

Yield: 82\% (0.0111 g)

$\mathrm{R}_{\mathrm{f}}:$ hex/EtOAc $(1 / 0.15,13 \%), 0.30$

The ee was determined by HPLC analysis on Chiralpak OJ-H column, hexane: isopropanol = 98/2; flow rate $=0.8 \mathrm{~mL} / \mathrm{min}$; UV detection at $220 \mathrm{~nm} ; \mathrm{t}_{\mathrm{R}}(S)=19.30 \mathrm{~min}($ minor $), \mathrm{t}_{\mathrm{R}}(R)=$ 22.72 min (major), ee $=97 \%(R)$. HPLC chromatograms are shown below for the racemic standard (top) and enantioenriched product (bottom). 
rac-3b

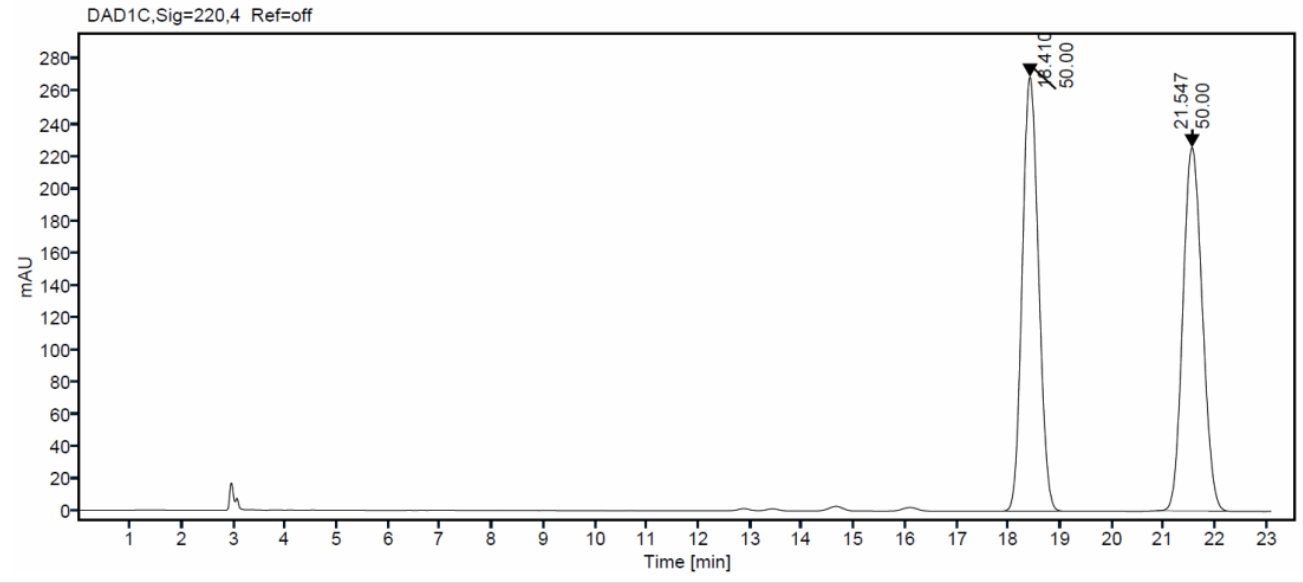

\section{Single Injection Report}

\section{Agilent Technologies}

Signal: $\quad$ DAD1C, $\operatorname{Sig}=220,4$ Ref $=$ off

$\begin{array}{rrr}\text { RT [min] } & \text { Area } & \text { Area\% } \\ 18.410 & 5899.1785 & 50.0034 \\ 21.547 & 5898.3657 & 49.9966\end{array}$

$(R)-\mathbf{3 b}$

Sum $\quad 11797.5442$

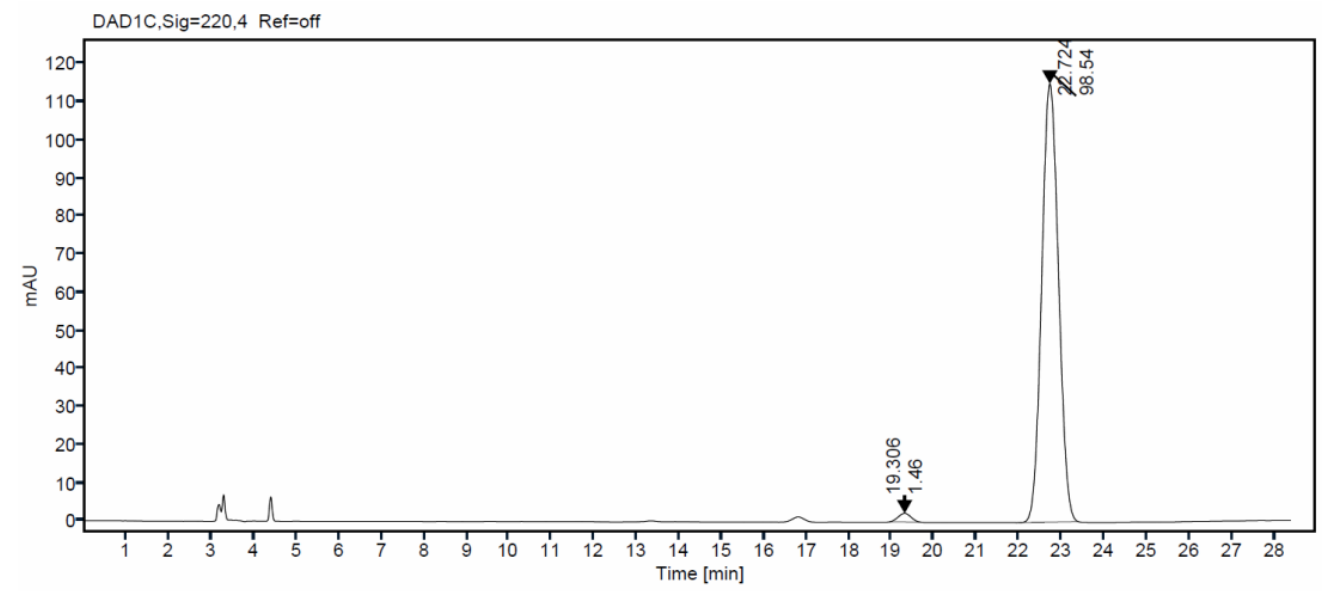

\section{Single Injection Report}

Signal: $\quad$ DAD1C, Sig $=220,4$ Ref $=$ off

$\begin{array}{rrr}\text { RT [min] } & \text { Area } & \text { Area\% } \\ 19.306 & 46.5900 & 1.4558 \\ 22.724 & 3153.7504 & 98.5442 \\ \text { Sum } & 3200.3404 & \end{array}$




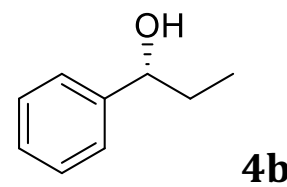

Synthesized using Method A.

${ }^{1} \mathrm{H}$ NMR (500 MHz, $\left.\mathrm{CDCl}_{3}\right) \delta:$ 7.37-7.35 (m, 4H), 7.30-7.27 (m, 1H), $4.60(\mathrm{t}, J=6.5 \mathrm{~Hz}, 1 \mathrm{H})$, $1.90(\mathrm{~s}, 1 \mathrm{H}), 1.87-1.72(\mathrm{~m}, 2 \mathrm{H}), 0.94(\mathrm{t}, J=7.4 \mathrm{~Hz}, 3 \mathrm{H})$.

${ }^{13} \mathrm{C}$ NMR $\left(126 \mathrm{MHz}, \mathrm{CDCl}_{3}\right) \delta: 144.59,128.39,127.49,125.97,76.02,31.88,10.14$.

Yield: 75\% (0.0107 g)

$\mathrm{R}_{\mathrm{f}}:$ hex/EtOAc (1/0.2: 16\%), 0.25

The ee was determined by HPLC analysis on Chiralpak OJ-H column, hexane: isopropanol = 95/5; flow rate $=1.0 \mathrm{~mL} / \mathrm{min}$; UV detection at $214 \mathrm{~nm} ; \mathrm{t}_{\mathrm{R}}(S)=9.11 \mathrm{~min}(\operatorname{minor}), \mathrm{t}_{\mathrm{R}}(R)=9.78$ min (major), ee $=93 \%(R)$. HPLC chromatograms are shown below for the racemic standard (top) and enantioenriched product (bottom). 
rac-4b

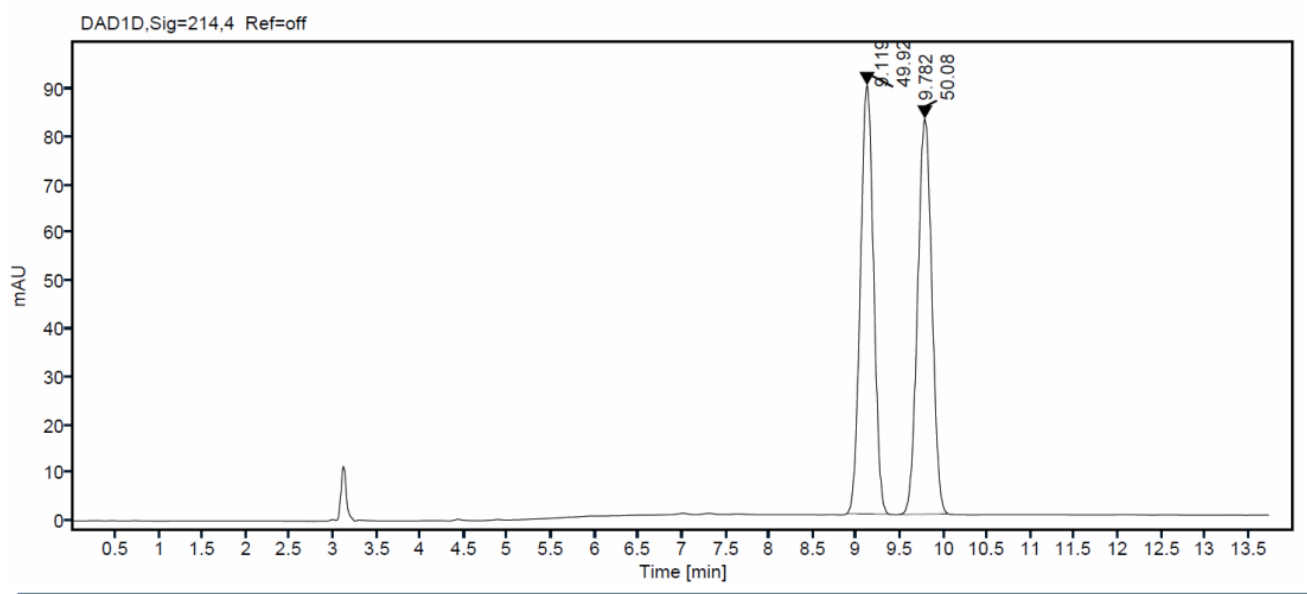

Single Injection Report

Agilent Technologies

Signal:

DAD1D, Sig=214,4 Ref=off

RT [min]

Area

Area $\%$

9.119

936.7546

49.9248

9.782

939.5751

50.0752

Sum

1876.3297

(R)-4b

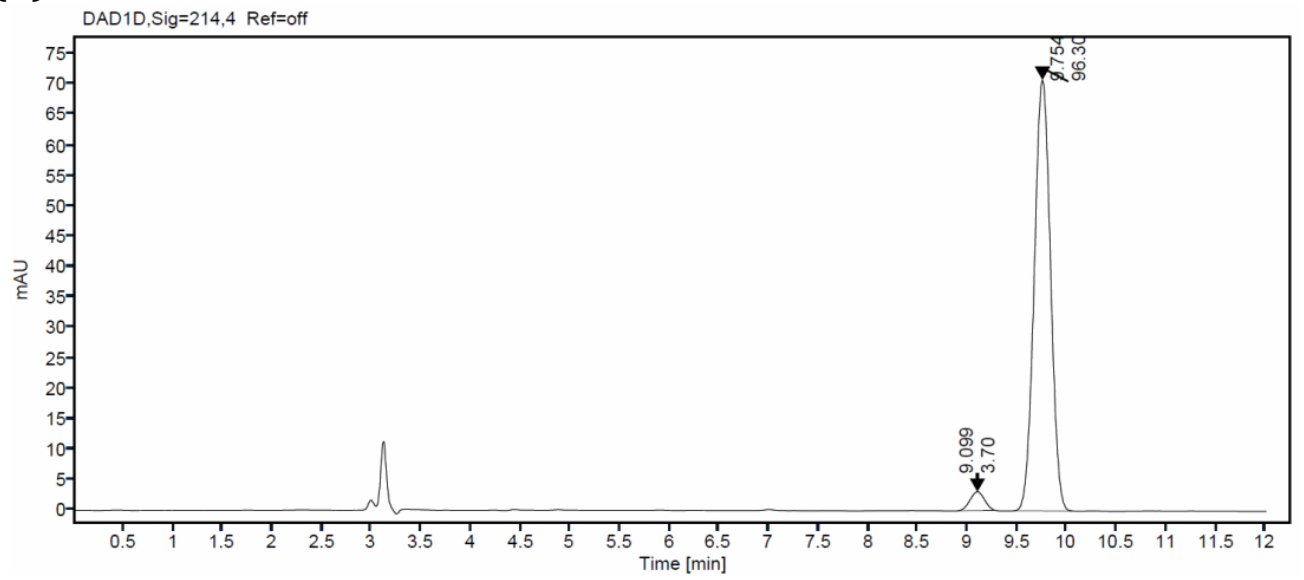

\section{Single Injection Report}

Signal: DAD1D, Sig=214,4 Ref=off

RT [min]
9.099
9.754
Sum

Area

30.9971

807.1733

838.1704
Area $\%$

3.6982

96.3018 


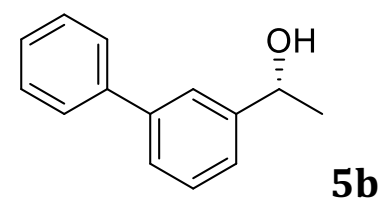

Prepared by Method B.

${ }^{1} \mathrm{H}$ NMR $\left(500 \mathrm{MHz}, \mathrm{CDCl}_{3}\right) \delta: 7.65-7.59(\mathrm{~m}, 3 \mathrm{H}), 7.52(\mathrm{dt}, J=7.6,1.6 \mathrm{~Hz}, 1 \mathrm{H}), 7.49-7.41(\mathrm{~m}$, $3 \mathrm{H}), 7.39-7.35(\mathrm{~m}, 2 \mathrm{H}), 4.97(\mathrm{q}, J=6.5 \mathrm{~Hz}, 1 \mathrm{H}), 1.99(\mathrm{bs}, 1 \mathrm{H}), 1.56(\mathrm{~d}, J=6.5 \mathrm{~Hz}, 3 \mathrm{H})$.

${ }^{13} \mathrm{C}$ NMR $\left(126 \mathrm{MHz}, \mathrm{CDCl}_{3}\right) \delta: 146.4,141.5,141.1,129.0,128.8,127.4,127.2,126.3,124.4$, $124.3,70.5,25.3$.

Yield: $88 \%$

$\mathrm{R}_{\mathrm{f}}:$ hex/EtOAc (1/0.33: 25\%), 0.29

HRMS (EI): $m / z$ calculated for $\left[\mathrm{C}_{14} \mathrm{H}_{14} \mathrm{O}\right]^{+}:$198.1045; [M] found: 198.1039

The ee was determined by HPLC analysis on Chiralpak OD-H column, hexane:IPA $=95 / 5$; flow rate $=1 \mathrm{~mL} / \mathrm{min}$; UV detection at $210 \mathrm{~nm}$; $\mathrm{t}_{\mathrm{R}}(S)=14.25 \mathrm{~min}($ minor $), \mathrm{t}_{\mathrm{R}}(R)=29.35 \mathrm{~min}$ (major), ee: $98 \%(R)$. HPLC chromatograms are shown below for the racemic standard (top) and enantioenriched product (bottom). 
rac-5b

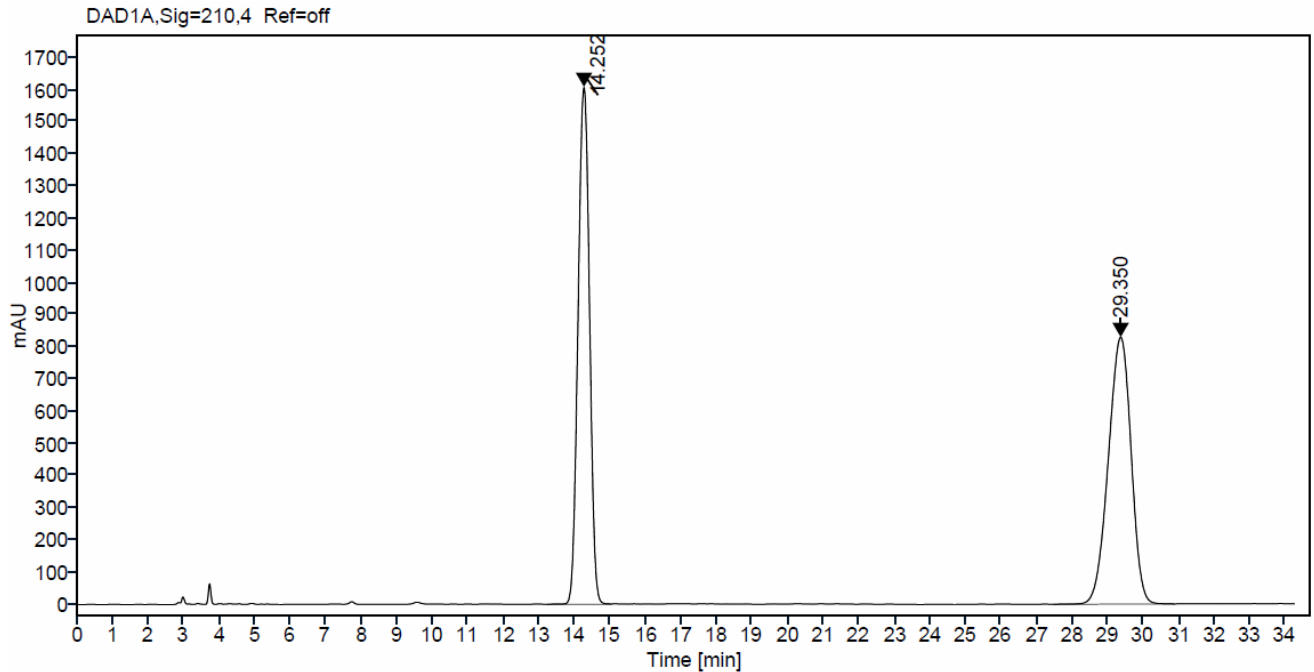

\section{Single Injection Report}

Agilent Technologies

$\begin{array}{rrr}\text { Signal: } & \text { DAD1A,Sig=210,4 } & \text { Ref }=\text { off } \\ \text { RT [min] } & \text { Area } & \text { Area } \% \\ 14.252 & 35953.5217 & 49.3396 \\ 29.350 & 36915.9444 & 50.6604\end{array}$

$(R)-5 \mathbf{b}$

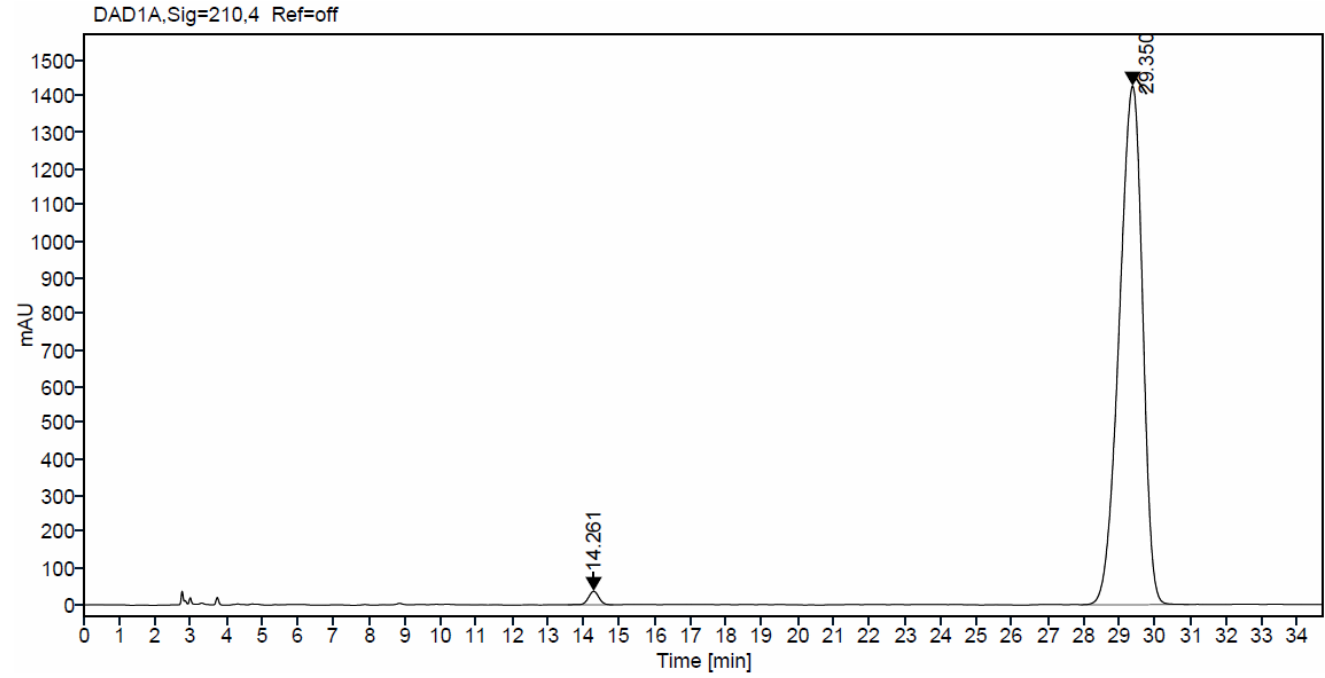

\section{Single Injection Report}

Agilent Technologies

\begin{tabular}{rrr}
\multicolumn{1}{l}{$\begin{array}{l}\text { Signal: } \\
\text { RT [min] }\end{array}$} & A Area & Area\% \\
14.261 & 768.3201 & 1.1737 \\
29.350 & 64694.1838 & 98.8263 \\
Sum & 65462.5039 &
\end{tabular}


(c)

Synthesized using Method A.

${ }^{1} \mathrm{H} \mathrm{NMR}\left(400 \mathrm{MHz}, \mathrm{CDCl}_{3}\right) \delta: 8.72(\mathrm{~d}, J=8.4 \mathrm{~Hz}, 1 \mathrm{H}), 8.68(\mathrm{~s}, 1 \mathrm{H}), 7.88(\mathrm{t}, J=8.1 \mathrm{~Hz}, 2 \mathrm{H}), 7.73$ $(\mathrm{s}, 2 \mathrm{H}), 7.60-7.68(\mathrm{~m}, 3 \mathrm{H}), 5.17(\mathrm{q}, J=6.4 \mathrm{~Hz}, 1 \mathrm{H}), 2.09(\mathrm{~s}, 1 \mathrm{H}), 1.64(\mathrm{~d}, J=6.4 \mathrm{~Hz}, 3 \mathrm{H})$.

${ }^{13} \mathrm{C}$ NMR $\left(101 \mathrm{MHz}, \mathrm{CDCl}_{3}\right) \delta: 144.0,132.2,131.4,130.2,130.2,128.9,128.6,126.8,126.6$, $126.6,126.5,124.2,122.7,119.1,70.9,25.5$.

Yield: 94\% (0.0208 g)

$\mathrm{R}_{\mathrm{f}}:$ hex/EtOAc (1/0.15: 13\%), 0.25

The ee was determined by HPLC analysis on Chiralpak OD-H column, hexane:IPA = 95/5; flow rate $=0.8 \mathrm{~mL} / \mathrm{min}$; UV detection at $254 \mathrm{~nm} ; \mathrm{t}_{\mathrm{R}}(R)=28.49 \mathrm{~min}$ (major), ee $=100 \%(R)$. HPLC chromatograms are shown below for the racemic standard (top) and enantioenriched product (bottom). 


\section{rac-6b}

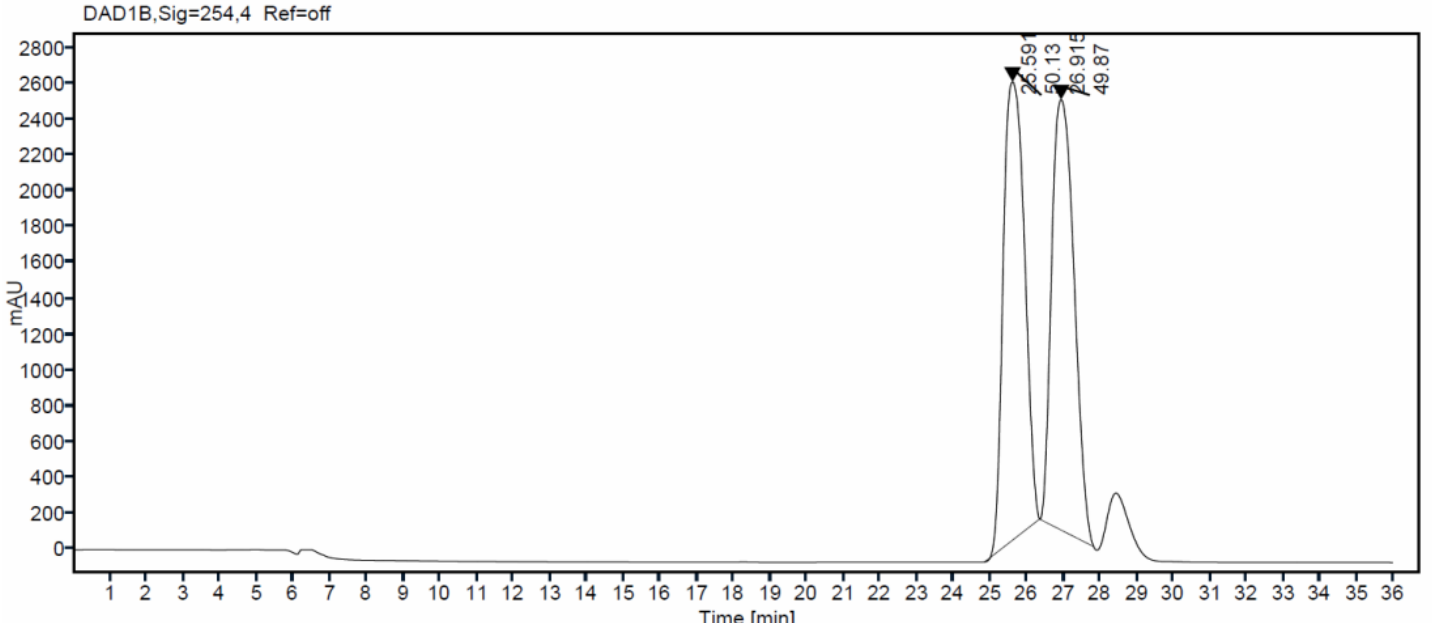

\section{Single Injection Report}

\section{Agilent Technologies}

Signal: DAD1B,Sig=254,4 Ref=off

$\begin{array}{rrr}\text { RT [min] } & \text { Area } & \text { Area\% } \\ 25.591 & 102923.9012 & 50.1314 \\ 26.915 & 102384.4727 & 49.8686 \\ \text { Sum } & 205308.3739 & \end{array}$

$(R)-6 \mathbf{b}$

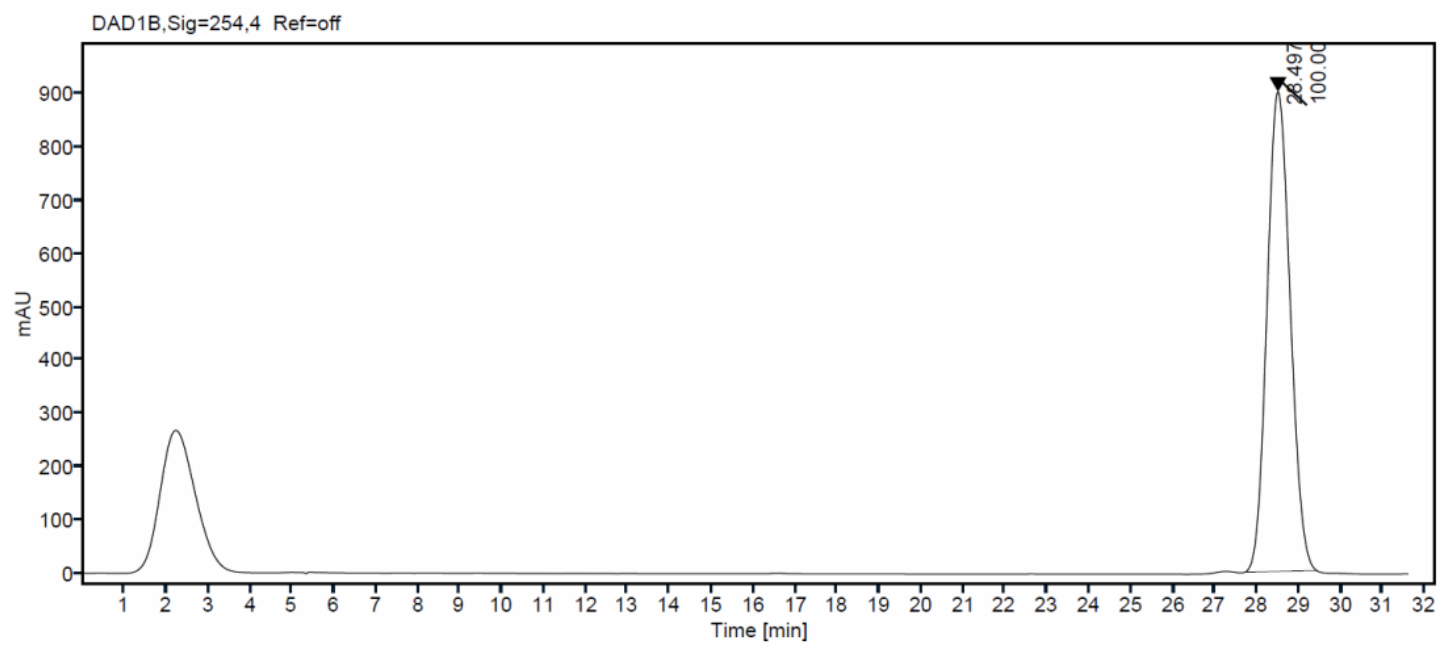

\section{Single Injection Report}

\section{Agilent Technologies}

Signal: $\quad$ DAD1B, Sig $=254,4$ Ref $=$ off

$\begin{array}{rrr}\text { RT [min] } & \text { Area } & \text { Area\% } \\ 28.497 & 34588.6291 & 100.0000 \\ \text { Sum } & 34588.6291 & \end{array}$


<smiles>C[C@H](O)c1ccc(Br)cc1</smiles>

Synthesized using Method A.

${ }^{1} \mathrm{H}$ NMR $\left(500 \mathrm{MHz}, \mathrm{CDCl}_{3}\right) \delta: 7.48(\mathrm{~d}, J=8.4 \mathrm{~Hz}, 2 \mathrm{H}), 7.27(\mathrm{~d}, J=8.4 \mathrm{~Hz}, 2 \mathrm{H}), 4.89(\mathrm{q}, J=6.4$ $\mathrm{Hz}, 1 \mathrm{H}), 1.81(\mathrm{~s}, 1 \mathrm{H}), 1.49(\mathrm{~d}, J=6.5 \mathrm{~Hz}, 2 \mathrm{H})$.

${ }^{13} \mathrm{C} \mathrm{NMR}\left(126 \mathrm{MHz}^{\mathrm{CDCl}}{ }_{3}\right) \delta: 144.7,131.6,127.1,121.2,69.8,25.3$.

Yield: $85 \%(0.0169 \mathrm{~g})$

$\mathrm{R}_{\mathrm{f}}:$ hex/EtOAc (1/0.15: 13\%), 0.30

The ee was determined by HPLC analysis on Chiralpak Cell2 column, hexane:IPA = 99/1; flow rate $=0.8 \mathrm{~mL} / \mathrm{min}$; UV detection at $232 \mathrm{~nm} ; \mathrm{t}_{\mathrm{R}}(R)=3.79$ min (major), $\mathrm{t}_{\mathrm{R}}(S)=4.14$ (minor), ee $=91 \%(R)$. HPLC chromatograms are shown below for the racemic standard (top) and enantioenriched product (bottom). 
rac-7b

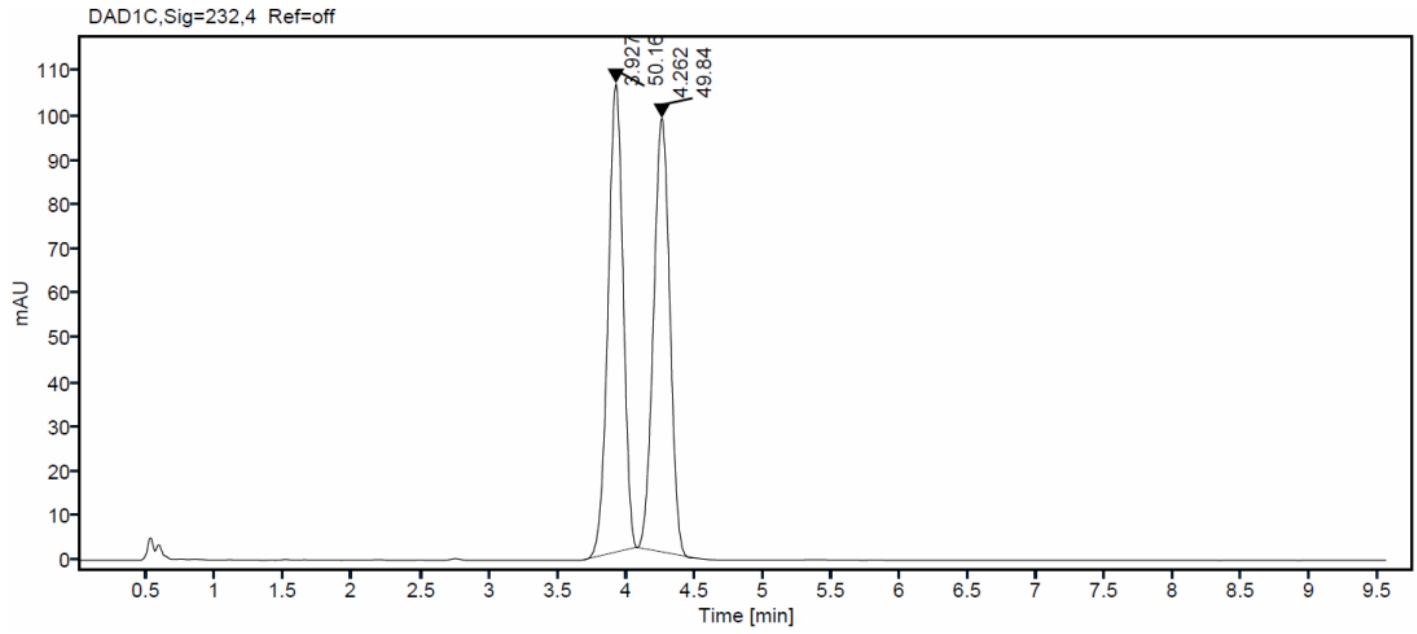

Single Injection Report

Agilent Technologies

Signal: $\quad$ DAD1C, $\operatorname{Sig}=232,4$ Ref $=$ off

RT [min]

3.927

4.262

Sum
Area

807.8983

802.8450

1610.7433

$(R)-7 \mathbf{b}$

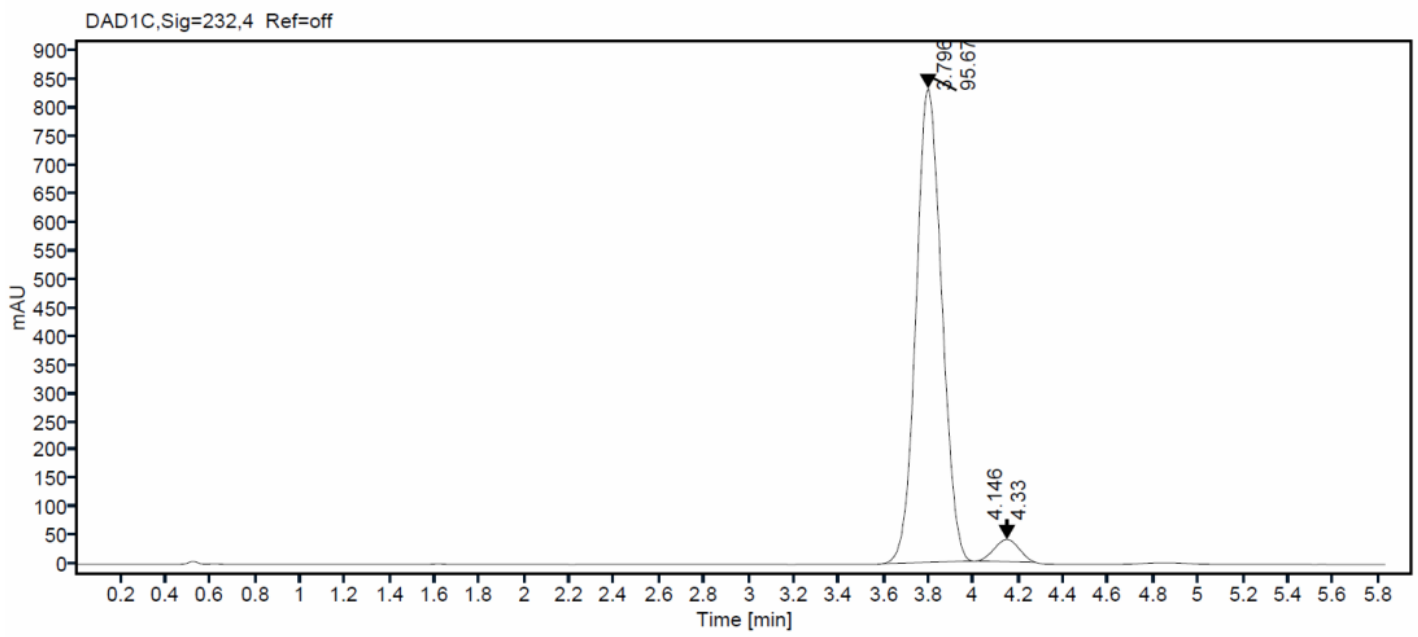

\section{Single Injection Report}

Signal:

DAD1C,Sig=232,4 Ref=off

RT [min]

3.796

4.146

Sum
Area

6623.2428

300.0238

6923.2666
49.8431 


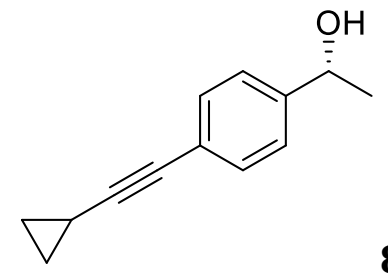

8b

Synthesized using Method A.

${ }^{1} \mathrm{H}$ NMR (400 MHz, $\left.\mathrm{CDCl}_{3}\right) \delta: 7.35(\mathrm{~d}, J=8.0 \mathrm{~Hz}, 2 \mathrm{H}), 7.27(\mathrm{~d}, J=7.2 \mathrm{~Hz}, 2 \mathrm{H}), 4.86(\mathrm{~d}, J=6.4$ $\mathrm{Hz}, 1 \mathrm{H}), 1.83(\mathrm{~s}, 1 \mathrm{H}), 1.46(\mathrm{~d}, J=6.8 \mathrm{~Hz}, 3 \mathrm{H}), 0.85-0.87(\mathrm{~m}, 2 \mathrm{H}), 0.79-0.85(\mathrm{~m}, 2 \mathrm{H})$.

${ }^{13} \mathrm{C}$ NMR $\left(101 \mathrm{MHz}, \mathrm{CDCl}_{3}\right) \delta: 145.0,131.7,125.2,122.9,93.3,75.5,70.1,25.1,8.6$.

Yield: 95\% (0.0176 g)

$\mathrm{R}_{\mathrm{f}}:$ hex/EtOAc (1/0.15: 13\%), 0.40

The ee was determined by HPLC analysis on Chiralpak OD-H column, hexane:IPA = 96/4; flow rate $=0.7 \mathrm{~mL} / \mathrm{min}$; $\mathrm{UV}$ detection at $250 \mathrm{~nm} ; \mathrm{t}_{\mathrm{R}}(S)=13.78 \mathrm{~min}$ (minor), $\mathrm{t}_{\mathrm{R}}(R)=19.05$ min (major), ee $=96 \%(R)$. HPLC chromatograms are shown below for the racemic standard (top) and enantioenriched product (bottom). 
rac-8b

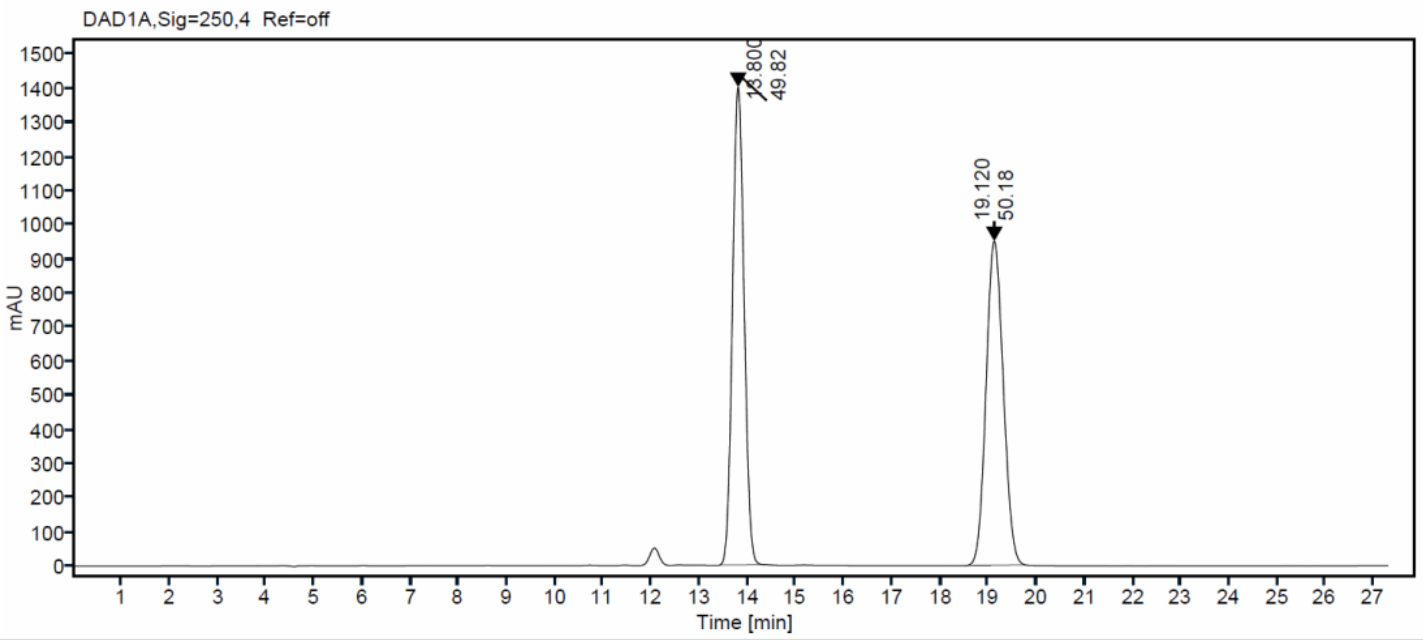

Single Injection Report

Agilent Technologies

Signal: $\quad$ DAD1A, Sig $=250,4$ Ref $=$ off

$\begin{array}{rrr}\text { RT [min] } & \text { Area } & \text { Area\% } \\ 13.800 & 23397.9936 & 49.8239 \\ 19.120 & 23563.3897 & 50.1761 \\ \text { Sum } & 46961.3833 & \end{array}$

$(R)-\mathbf{8 b}$

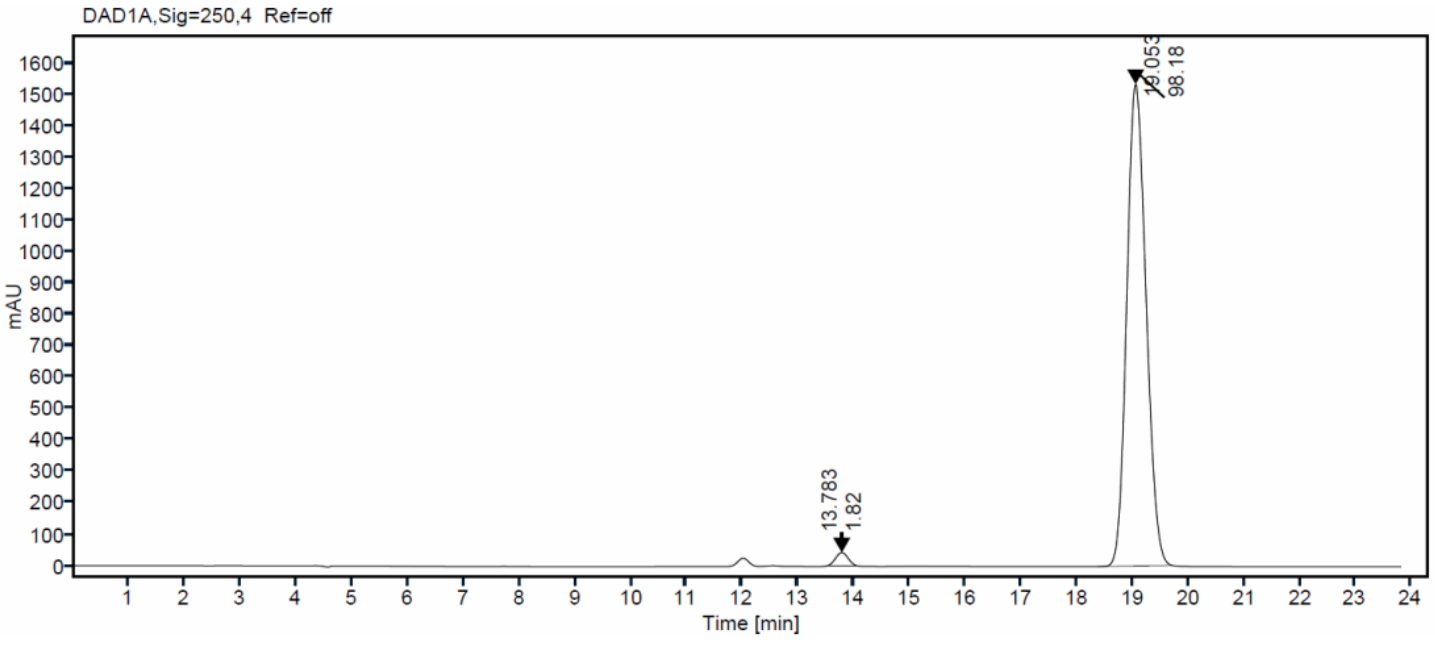

\section{Single Injection Report}

\section{Agilent Technologies}

Signal: $\quad$ DAD1A,Sig $=250,4$ Ref $=$ off

$\begin{array}{rrr}\text { RT [min] } & \text { Area } & \text { Area\% } \\ 13.783 & 684.3970 & 1.8172 \\ 19.053 & 36978.7430 & 98.1828 \\ \text { Sum } & 37663.1400 & \end{array}$




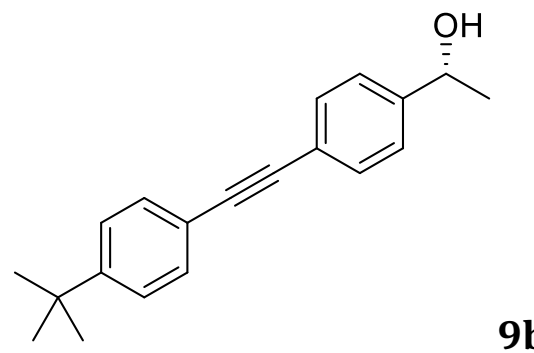

Synthesized using Method A.

${ }^{1} \mathrm{H}$ NMR (400 MHz, $\left.\mathrm{CDCl}_{3}\right) \delta: 7.51(\mathrm{~d}, J=8.0 \mathrm{~Hz}, 2 \mathrm{H}), 7.46(\mathrm{~d}, J=8.0 \mathrm{~Hz}, 2 \mathrm{H}), 7.34-7.38(\mathrm{~m}$, $4 \mathrm{H}), 4.91(\mathrm{q}, \mathrm{J}=6.8 \mathrm{~Hz}, 1 \mathrm{H}), 1.87(\mathrm{~s}, 1 \mathrm{H}) 1.50(\mathrm{~d}, J=6.4 \mathrm{~Hz}, 3 \mathrm{H}), 1.33(\mathrm{~s}, 9 \mathrm{H})$.

${ }^{13} \mathrm{C}$ NMR $\left(101 \mathrm{MHz} \mathrm{CDCl}_{3}\right) \delta: 151.5,145.7,131.7,131.3,125.3,131.3,125.3,122.5,120.1$, $89.4,88.5,70.1,34.8,31.2,25.2$

Yield: $89 \%(0.0247 \mathrm{~g})$

$\mathrm{R}_{\mathrm{f}}:$ hex/EtOAc (1/0.15: 13\%), 0.40

HRMS (ESI): $m / z$ calculated for $\left[\mathrm{C}_{20} \mathrm{H}_{20}\right]^{+}: 260.1565 ;\left[\mathrm{M}-\mathrm{H}_{2} \mathrm{O}\right]^{+}$found: 260.1567

The ee was determined by HPLC analysis on Chiralpak OD-H column, hexane:IPA = 96:4; flow rate $=0.7 \mathrm{~mL} / \mathrm{min}$; $\mathrm{UV}$ detection at $250 \mathrm{~nm} ; \mathrm{t}_{\mathrm{R}}(S)=36.42 \mathrm{~min}(\operatorname{minor}), \mathrm{t}_{\mathrm{R}}(R)=39.24 \mathrm{~min}$ (major), ee $=93 \%(R)$. HPLC chromatograms are shown below for the racemic standard (top) and enantioenriched product (bottom). 
rac-9b

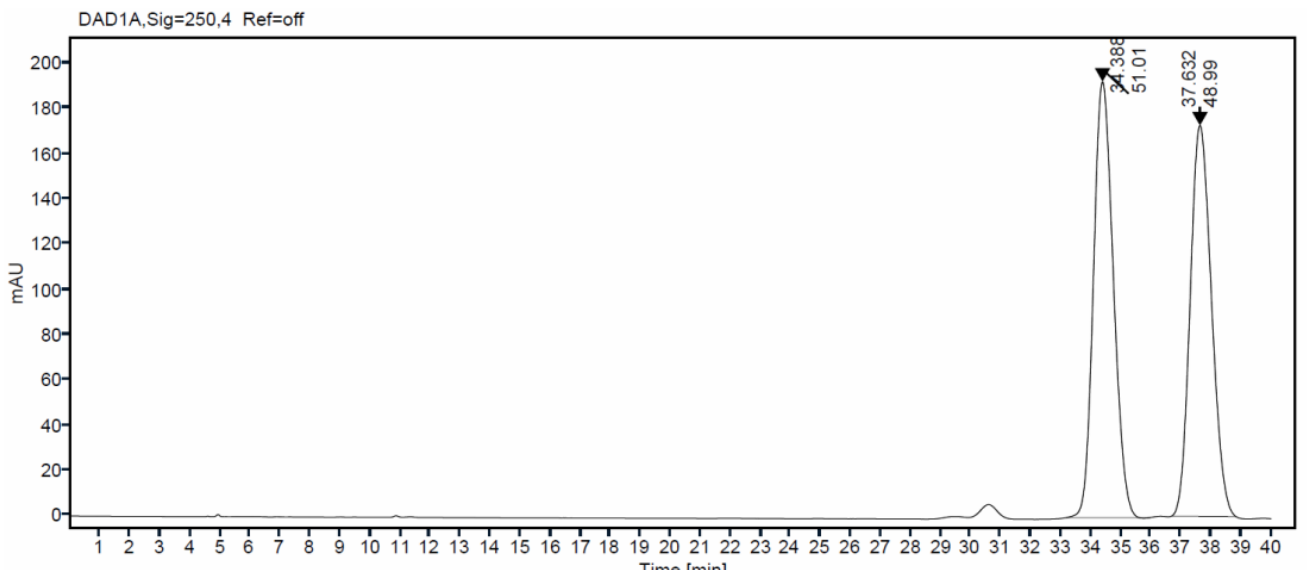

\section{Single Injection Report}

\section{Agilent Technologies}

Signal:

DAD1A, Sig=250,4 Ref=off

RT [min]

34.388

37.632

Sum
Area

8839.8961

8490.6168

17330.5129

$(R)-9 \mathbf{b}$

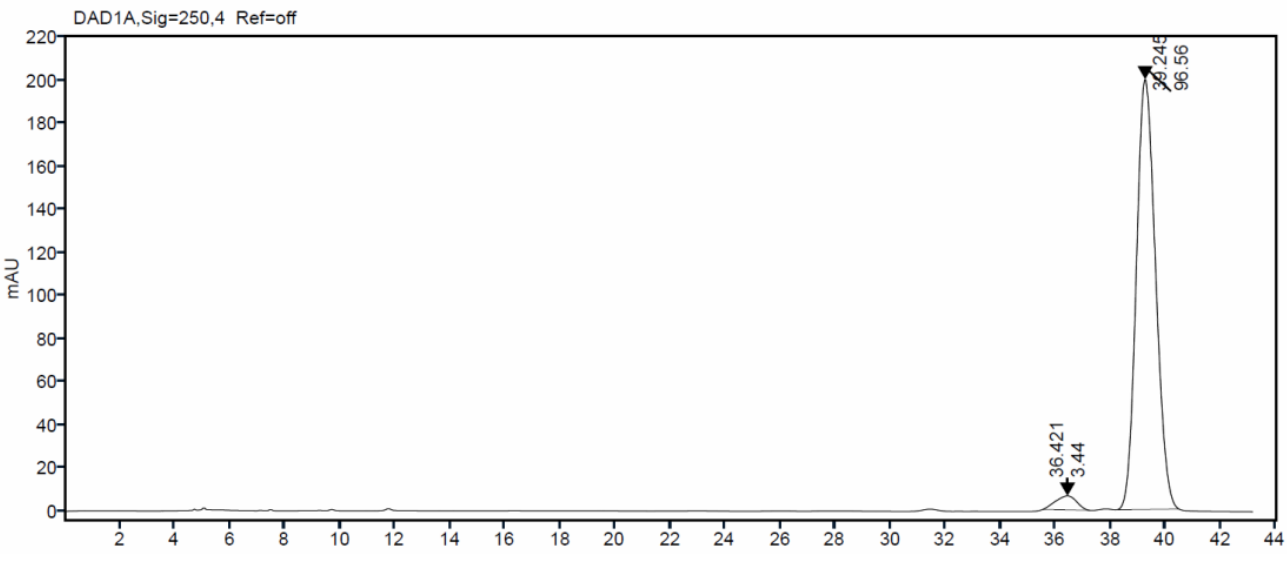

\section{Single Injection Report}

\section{Agilent Technologies}

Signal:

DAD1A, Sig $=250,4$ Ref $=$ off
RT [min]
36.421
39.245
Sum

$\begin{array}{rr}\text { Area } & \text { Area\% } \\ 345.5043 & 3.4356 \\ 9711.0666 & 96.5644 \\ 10056.5710 & \end{array}$




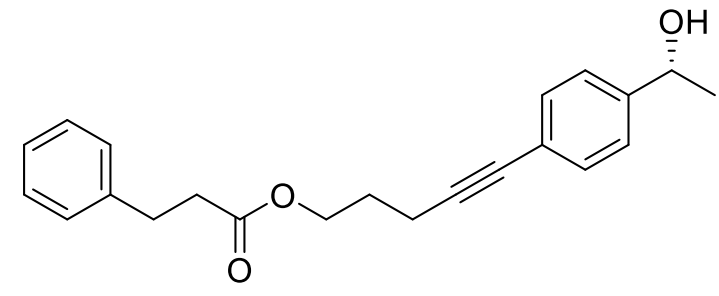

10b

Synthesized using Method A.

${ }^{1} \mathrm{H}$ NMR $\left(500 \mathrm{MHz}, \mathrm{CDCl}_{3}\right) \delta: 7.24(\mathrm{~d}, J=8.1 \mathrm{~Hz}, 2 \mathrm{H}), 7.14(\mathrm{~d}, 4 \mathrm{H}), 7.12-7.05(\mathrm{~m}, 3 \mathrm{H}), 4.75(\mathrm{q}$, $J=6.4 \mathrm{~Hz}, 1 \mathrm{H}), 4.09(\mathrm{t}, J=6.3 \mathrm{~Hz}, 2 \mathrm{H}), 2.82(\mathrm{t}, J=7.8 \mathrm{~Hz}, 2 \mathrm{H}), 2.51(\mathrm{t}, J=7.8 \mathrm{~Hz}, 2 \mathrm{H}), 2.32(\mathrm{t}, J$ $=7.0 \mathrm{~Hz}, 2 \mathrm{H}), 1.77(\mathrm{p}, J=6.7 \mathrm{~Hz}, 2 \mathrm{H}), 1.68(\mathrm{~s}, 1 \mathrm{H}), 1.34(\mathrm{~d}, J=6.5 \mathrm{~Hz}, 3 \mathrm{H})$.

${ }^{13} \mathrm{C}$ NMR $\left(126 \mathrm{MHz}, \mathrm{CDCl}_{3}\right) \delta: 172.9,145.4,140.5,131.7,128.5,128.3,126.3,125.3,122.8$, 88.5, 81.1, 70.1, 63.2, 35.9, 31.0, 27.8, 25.1, 16.2.

Yield: $60 \%(0.02 \mathrm{~g})$

Rf: hex/EtOAc (1/0.2: 16\%), 0.30

HRMS (ESI): $m / z$ calculated for $\left[\mathrm{C}_{22} \mathrm{H}_{22} \mathrm{O}_{2}\right]^{+}: 318.1620$; $\left[\mathrm{M}-\mathrm{H}_{2} \mathrm{O}\right]^{+}$found: 318.1627

The ee was determined by HPLC analysis on Chiralpak OD-H column, hexane:IPA $=85 / 15$; flow rate $=1.0 \mathrm{~mL} / \mathrm{min} ; \mathrm{UV}$ detection at $250 \mathrm{~nm} ; \mathrm{t}_{\mathrm{R}}(S)=13.78 \mathrm{~min}\left(\right.$ minor), $\mathrm{t}_{\mathrm{R}}(R)=14.78 \mathrm{~min}$ (major), ee $=93 \%(R)$. HPLC chromatograms are shown below for the racemic standard (top) and enantioenriched product (bottom). 
rac-10b

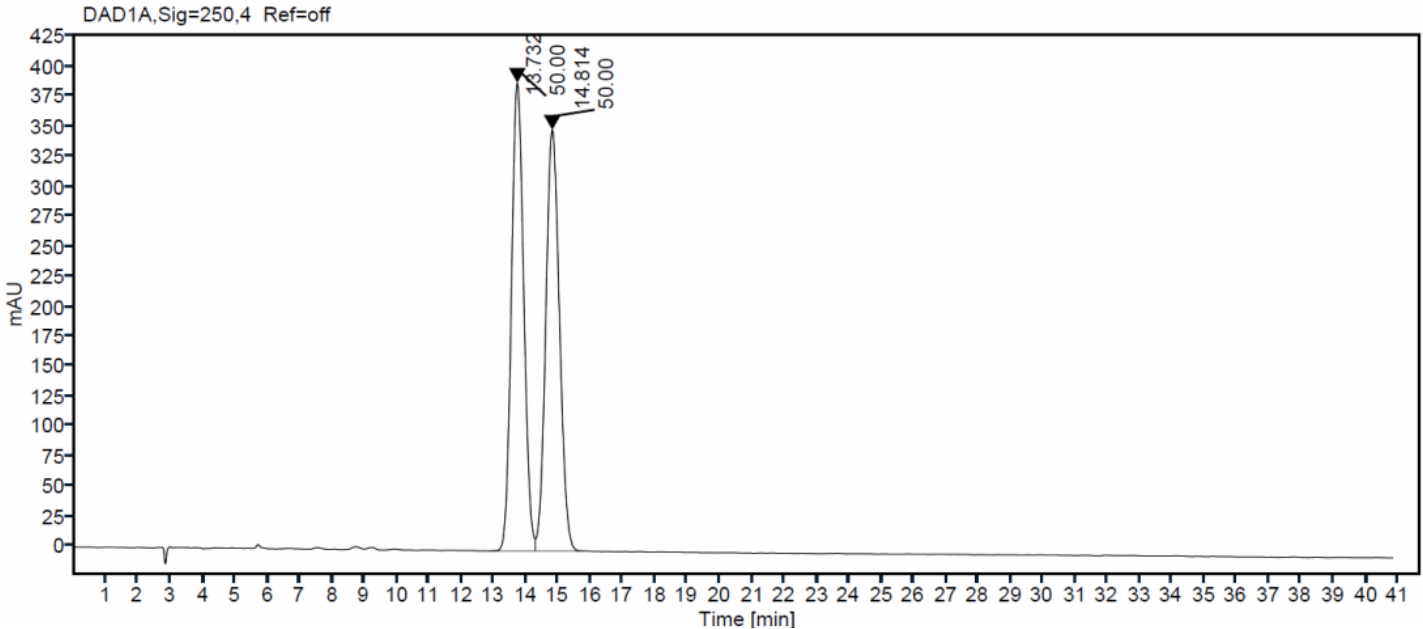

\section{Single Injection Report}

Signal: $\quad$ DAD1A, Sig $=250,4$ Ref $=$ off

RT [min]

13.732

14.814

Sum
Area

10306.2953

10304.9764

20611.2717

$(R)-\mathbf{1 0 b}$

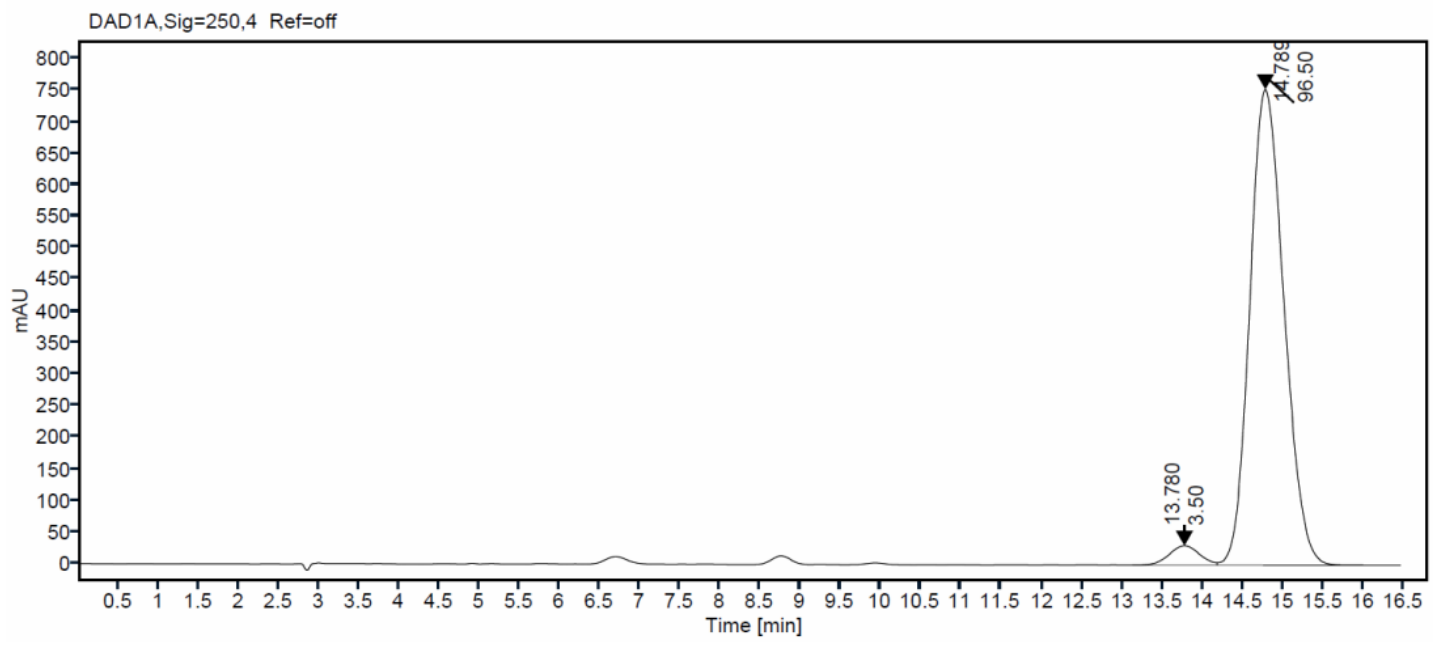

\section{Single Injection Report}

\section{Area \%}

50.0032

49.9968

\section{Agilent Technologies}


<smiles>CCOC(=O)c1ccc(-c2ccc([C@@H](C)O)cc2)cc1</smiles>

11b

Synthesized using Method A.

${ }^{1} \mathrm{H}$ NMR (500 MHz, $\left.\mathrm{CDCl}_{3}\right) \delta: 8.11(\mathrm{~d}, J=8.1 \mathrm{~Hz}, 2 \mathrm{H}), 7.65(\mathrm{~d}, J=7.5 \mathrm{~Hz}, 2 \mathrm{H}), 7.62(\mathrm{~d}, J=8.0$ $\mathrm{Hz}, 2 \mathrm{H}), 7.48(\mathrm{~d}, J=7.5 \mathrm{~Hz}, 2 \mathrm{H}), 4.98(\mathrm{q}, J=6.5 \mathrm{~Hz}, 1 \mathrm{H}), 4.41(\mathrm{q}, J=7.0 \mathrm{~Hz}, 2 \mathrm{H}), 2.05(\mathrm{~s}, 1 \mathrm{H})$, $1.55(\mathrm{~d}, J=6.5 \mathrm{~Hz}, 3 \mathrm{H}), 1.42(\mathrm{t}, J=7.0 \mathrm{~Hz}, 3 \mathrm{H})$.

${ }^{13} \mathrm{C} \mathrm{NMR}\left(126 \mathrm{MHz}, \mathrm{CDCl}_{3}\right) \delta: 166.5,145.8,145.2,139.2,130.1,129.3,127.4,126.9,126.0$, $70.1,61.0,25.3,14.4$.

Yield: 97\% (0.0261 g)

$\mathrm{R}_{\mathrm{f}}$ : hex/EtOAc (1/0.2: 16\%), 0.15

HRMS (ESI): $m / z$ calculated for $\left[\mathrm{C}_{17} \mathrm{H}_{16} \mathrm{O}_{2}\right]^{+}: 252.1150 ;\left[\mathrm{M}-\mathrm{H}_{2} \mathrm{O}\right]^{+}$found: 252.1152

ICP-MS: trace Cu: $0.000 \pm 0.000 \mu \mathrm{g} / \mathrm{g}$ (sample weight; $0.33 \mathrm{mg}$ )

The ee was determined by HPLC analysis on Chiralpak Cell2 column, hexane:IPA = 93/7; flow rate $=1.0 \mathrm{~mL} / \mathrm{min}$; UV detection at $210 \mathrm{~nm} ; \mathrm{t}_{\mathrm{R}}(S)=2.16 \mathrm{~min}(\operatorname{minor}), \mathrm{t}_{\mathrm{R}}(R)=2.53 \mathrm{~min}$ (major), ee $=96 \%(R)$. HPLC chromatograms are shown below for the racemic standard (top) and enantioenriched product (bottom). 
rac-11b

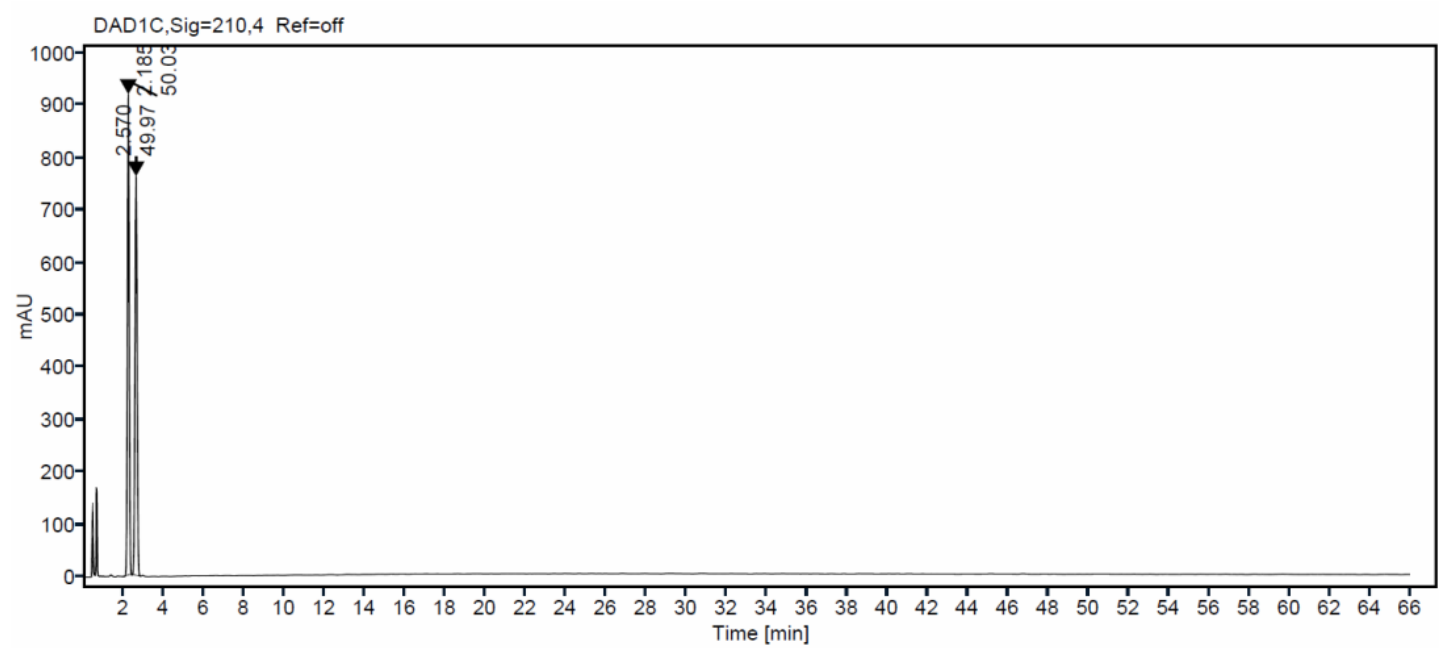

\section{Single Injection Report}

\section{Agilent Technologies}

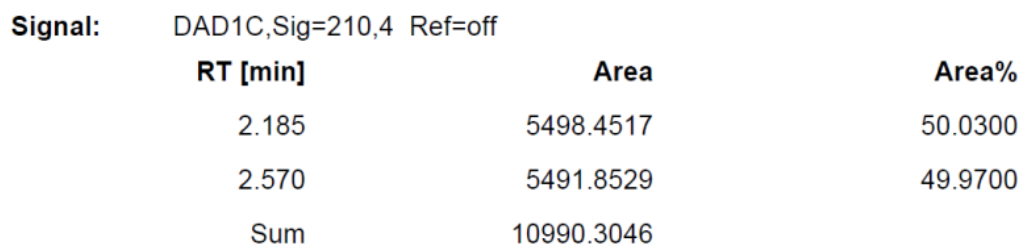

\section{$(R)-\mathbf{1 1 b}$}

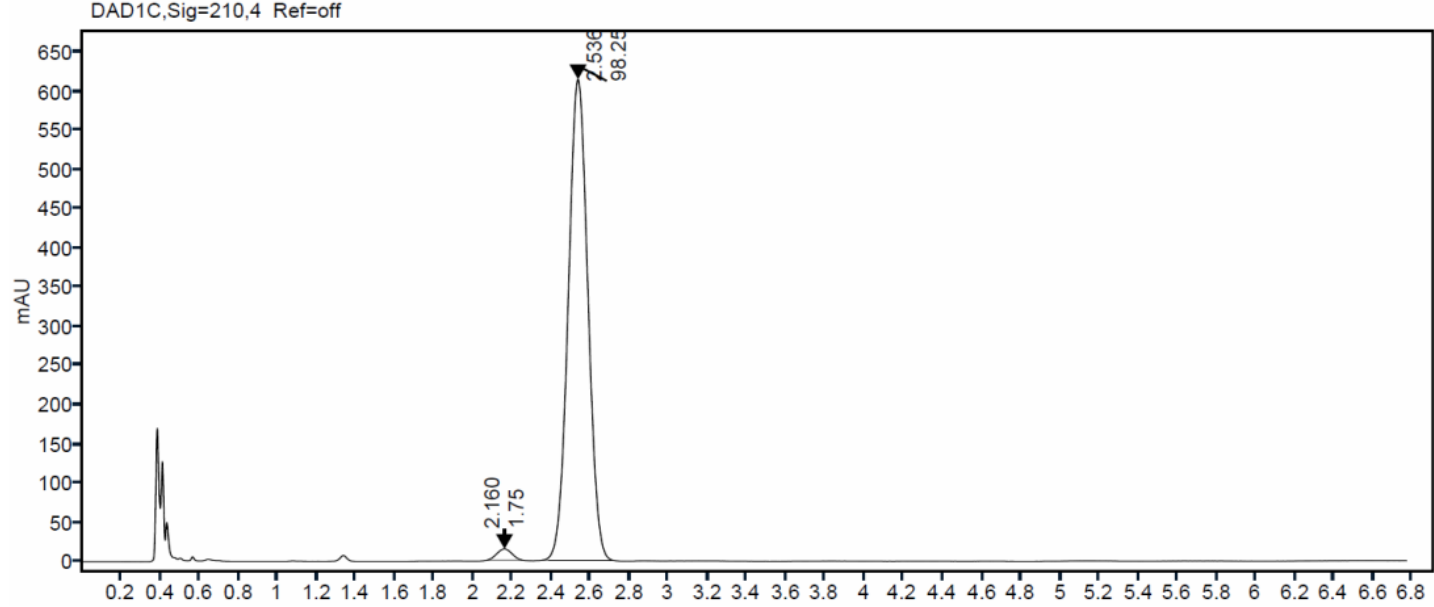

\section{Single Injection Report}

Signal: $\quad$ DAD1C, $S i g=210,4$ Ref $=$ off

$\begin{array}{rrr}\text { RT [min] } & \text { Area } & \text { Area\% } \\ 2.160 & 76.3332 & 1.7511 \\ 2.536 & 4282.8356 & 98.2489 \\ \text { Sum } & 4359.1689 & \end{array}$


<smiles>C[C@H](O)c1ccc(/C=C/c2ccc(F)cc2)cc1</smiles>

Synthesized using Method A.

${ }^{1} \mathrm{H} \mathrm{NMR}\left(500 \mathrm{MHz}, \mathrm{CDCl}_{3}\right) \delta: 7.55(\mathrm{~s}, 1 \mathrm{H}), 7.48-7.50(\mathrm{~m}, 2 \mathrm{H}), 7.42(\mathrm{~m}, 1 \mathrm{H}), 7.36(\mathrm{t}, J=7.6 \mathrm{~Hz}$, $1 \mathrm{H}), 7.28(\mathrm{~d}, J=8.0 \mathrm{~Hz}, 1 \mathrm{H}), 7.02-7.12(\mathrm{~m}, 4 \mathrm{H}), 4.95(\mathrm{q}, J=6.4 \mathrm{~Hz}, 1 \mathrm{H}), 1.91(\mathrm{~s}, 1 \mathrm{H}), 1.55(\mathrm{~d}, J$ $=6.5 \mathrm{~Hz}, 3 \mathrm{H})$.

${ }^{13} \mathrm{C}$ NMR $\left(126 \mathrm{MHz}_{\mathrm{CDCl}}\right) \delta$ : $163.3,161.4,146.3,137.4,133.4(\mathrm{~d}, J=3.4 \mathrm{~Hz}), 128.9,128.3$ $(\mathrm{d}, J=2.39 \mathrm{~Hz}), 128.0(\mathrm{~d}, J=8.06 \mathrm{~Hz}), 125.6,124.8,123.3,115.6$ (d, $J=21.67 \mathrm{~Hz}), 70.4,25.3$.

Yield: 96\% (0.0232 g)

$\mathrm{R}_{\mathrm{f}}:$ hex/EtOAc (1/0.2: 16\%), 0.25

The ee was determined by HPLC analysis on Chiralpak Cell2 column, hexane:IPA = 99.5/0.5; flow rate $=0.6 \mathrm{~mL} / \mathrm{min}$; UV detection at $214 \mathrm{~nm} ; \mathrm{t}_{\mathrm{R}}(S)=10.50 \mathrm{~min}(\operatorname{minor}), \mathrm{t}_{\mathrm{R}}(R)=11.36 \mathrm{~min}$ (major), ee $=99 \%(R)$. HPLC chromatograms are shown below for the racemic standard (top) and enantioenriched product (bottom). 
rac-12b

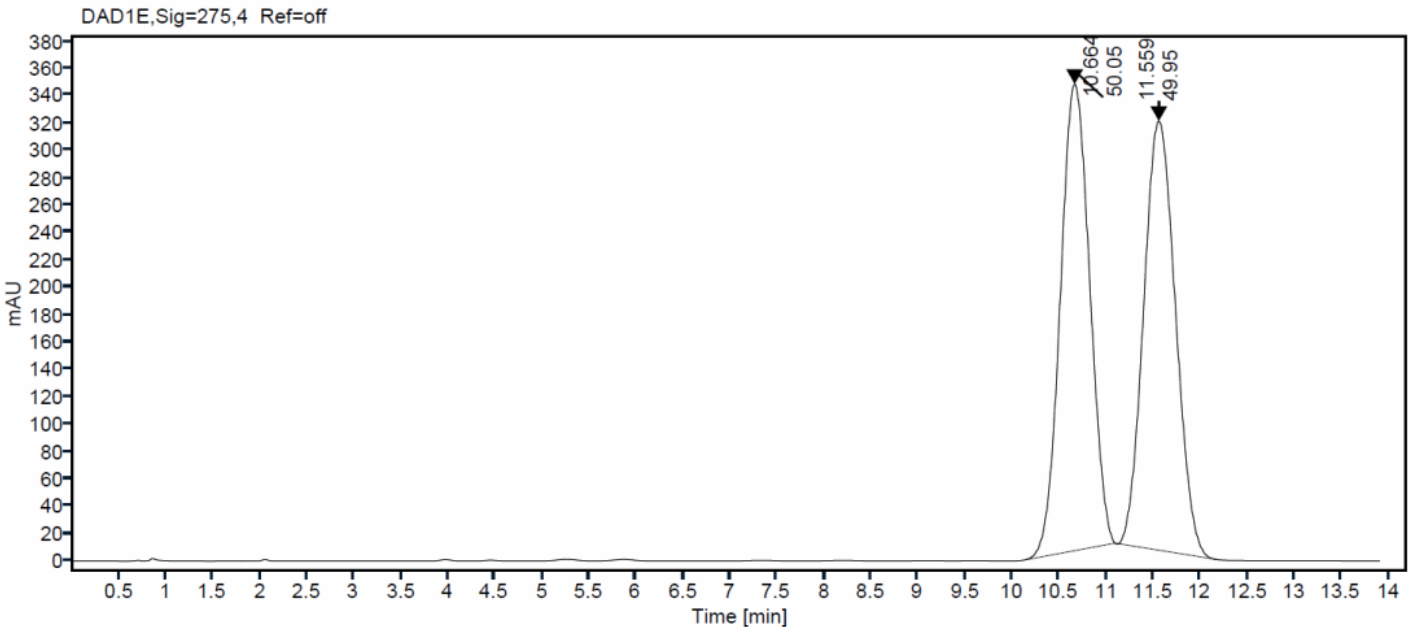

\section{Single Injection Report}

Signal: $\quad$ DAD1E, $\operatorname{Sig}=275,4$ Ref=off

$\begin{array}{rrr}\text { RT [min] } & \text { Area } & \text { Area\% } \\ 10.664 & 7386.9765 & 50.0549 \\ 11.559 & 7370.7733 & 49.9451 \\ \text { Sum } & 14757.7498 & \end{array}$

$(R)-\mathbf{1 2 b}$

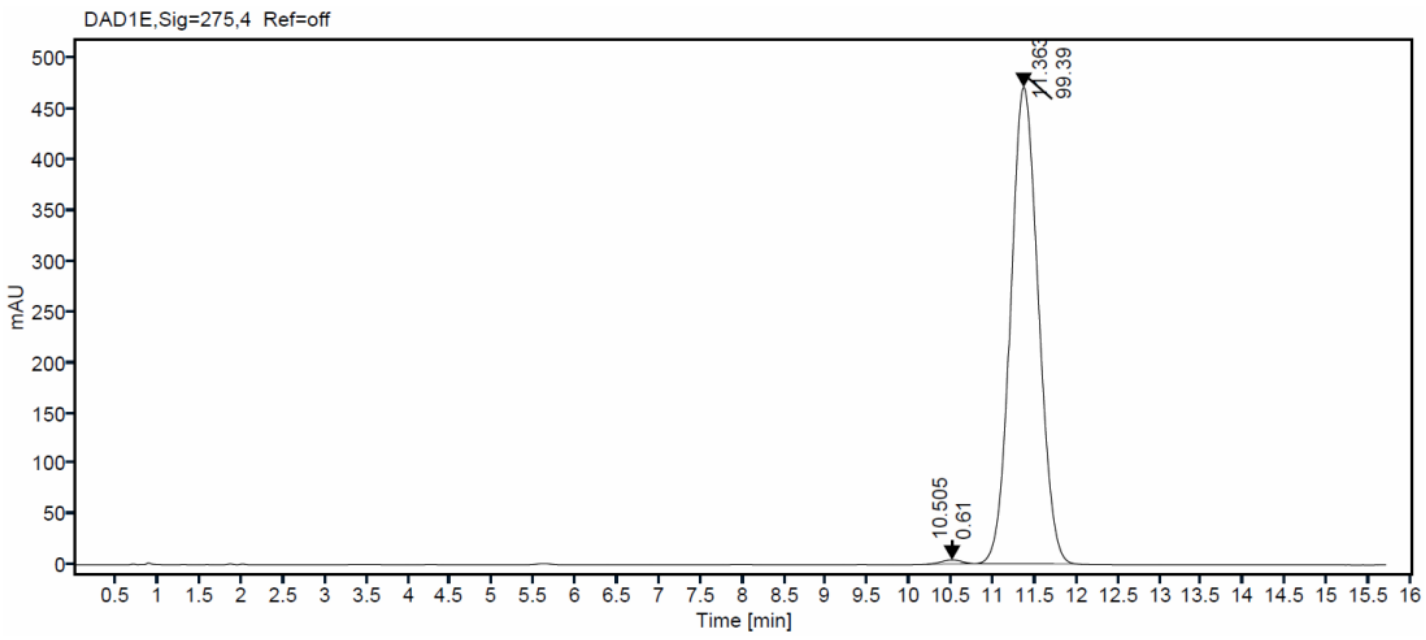

\section{Single Injection Report}

Signal: DAD1E,Sig=275,4 Ref=off

$\begin{array}{rrr}\text { RT [min] } & \text { Area } & \text { Area\% } \\ 10.505 & 67.1683 & 0.6144 \\ 11.363 & 10864.3000 & 99.3856 \\ \text { Sum } & 10931.4682 & \end{array}$


<smiles>C[C@H](O)c1ccc(-c2cc(C(F)(F)F)cc(C(F)(F)F)c2)cc1</smiles>

\section{$13 b$}

Synthesized using Method A.

${ }^{1} \mathrm{H}$ NMR (500 MHz, $\left.\mathrm{CDCl}_{3}\right) \delta: 8.02(\mathrm{~s}, 2 \mathrm{H}), 7.87(\mathrm{~s}, 1 \mathrm{H}), 7.62(\mathrm{~d}, J=8.0 \mathrm{~Hz}, 2 \mathrm{H}), 7.54(\mathrm{~d}, J=8.5$ $\mathrm{Hz}, 2 \mathrm{H}), 5.01(\mathrm{q}, J=6.5 \mathrm{~Hz}, 1 \mathrm{H}), 1.83(\mathrm{~s}, 1 \mathrm{H}), 1.56(\mathrm{~d}, J=6.5 \mathrm{~Hz}, 3 \mathrm{H})$.

${ }^{13} \mathrm{C}$ NMR (126 MHz, $\left.\mathrm{CDCl}_{3}\right) \delta: 146.7,143.0,137.3,132.1(\mathrm{q}, J=33.2 \mathrm{~Hz}), 127.4,127.1,126.3$, $123.4(\mathrm{q}, J=273.16 \mathrm{~Hz}), 120.8-120.9(\mathrm{~m}), 70.0,25.4$.

Yield: $87 \%$ (0.0290 g)

$\mathrm{R}_{\mathrm{f}}:$ hex/EtOAc (1/0.3: 23\%), 0.25

The ee was determined by HPLC analysis on Chiralpak OD-H column, hexane:IPA = 97/3; flow rate $=1.0 \mathrm{~mL} / \mathrm{min}$; UV detection at $250 \mathrm{~nm}$; $\mathrm{t}_{\mathrm{R}}(R)=9.53 \mathrm{~min}$ (major), $\mathrm{t}_{\mathrm{R}}(S)=13.13 \mathrm{~min}$ (minor), ee $=96 \%(R)$. HPLC chromatograms are shown below for the racemic standard (top) and enantioenriched product (bottom). 
rac-13b

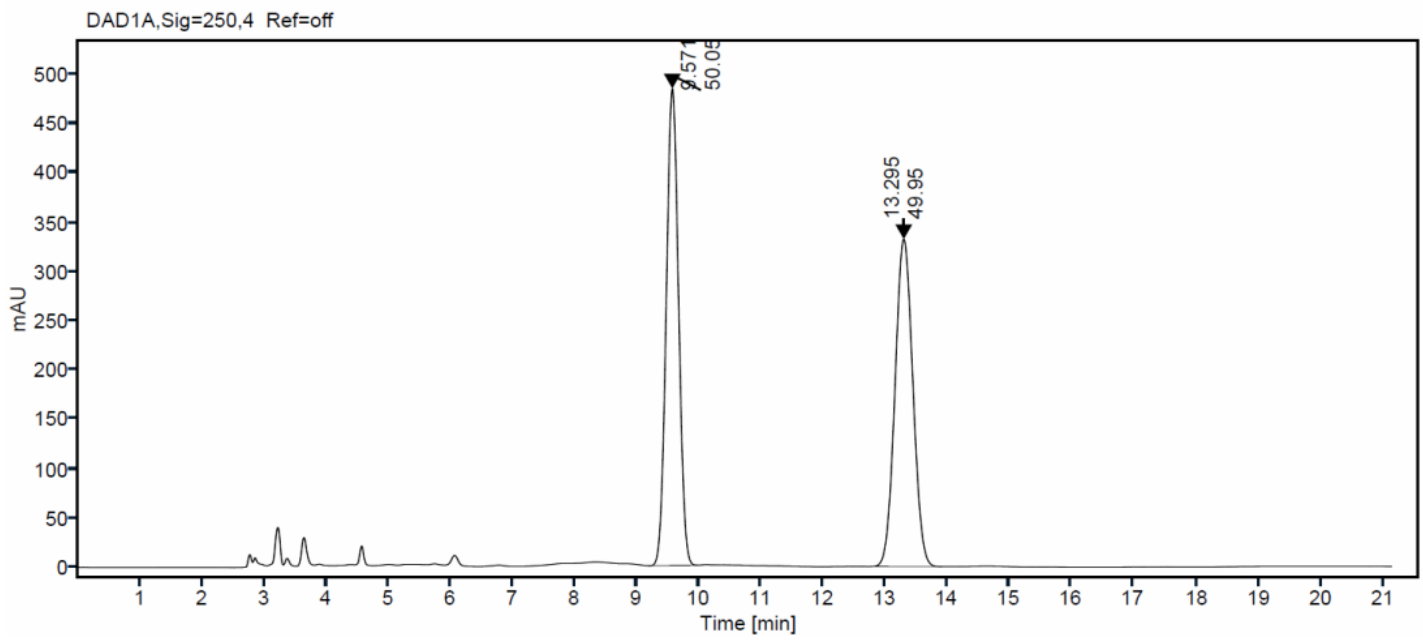

\section{Single Injection Report}

Signal: $\quad$ DAD1A, Sig $=250,4$ Ref $=$ off

RT [min]

9.571

13.295

Sum
Area

6645.8477

6631.4068

13277.2546

\section{$(R)-\mathbf{1 3 b}$}

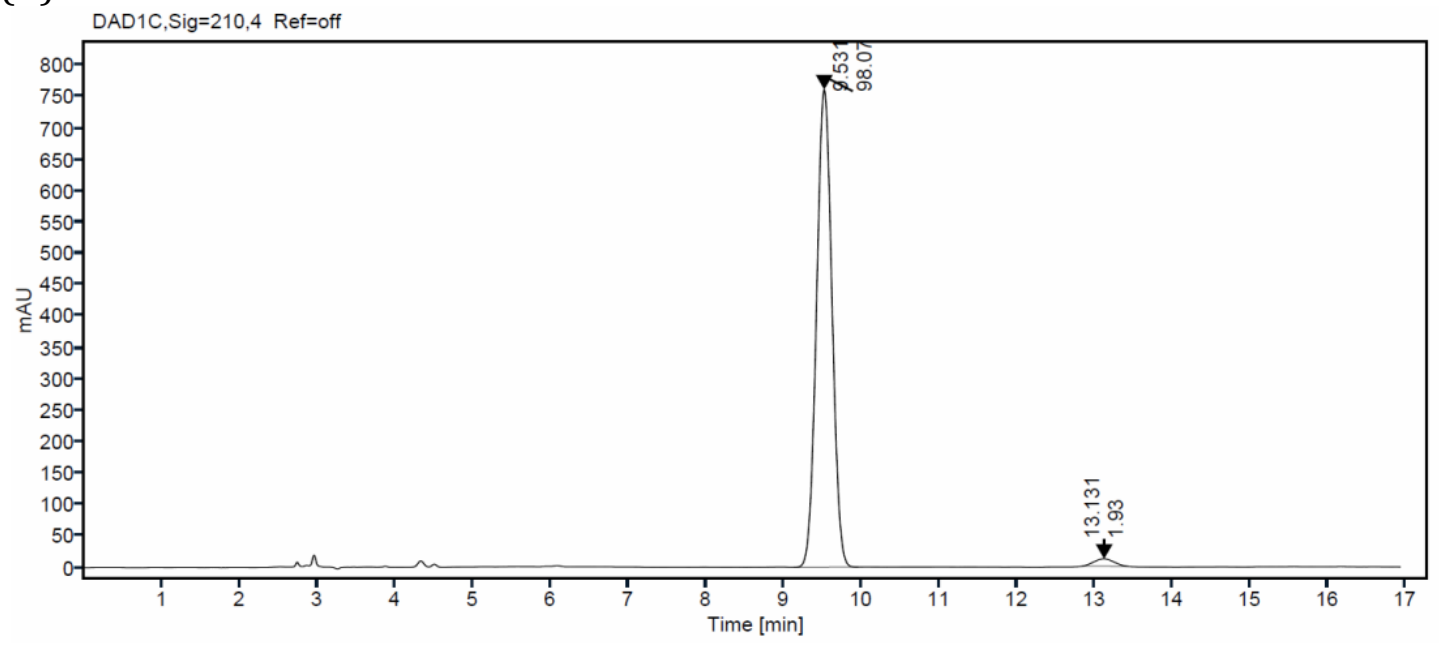

\section{Single Injection Report}

Signal: $\quad$ DAD1C,, ig $=210,4$ Ref $=$ off

$\begin{array}{rr}\text { RT [min] } & \text { Area } \\ 9.531 & 10499.7177 \\ 13.131 & 206.6690 \\ \text { Sum } & 10706.3867\end{array}$




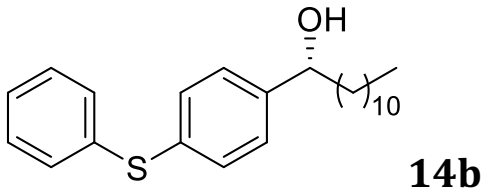

Synthesized using Method A.

${ }^{1} \mathrm{H}$ NMR (500 MHz, $\left.\mathrm{CDCl}_{3}\right) \delta: 7.31(\mathrm{~m}, 9 \mathrm{H}), 4.66(\mathrm{t}, J=5.4 \mathrm{~Hz}, 2 \mathrm{H}), 1.70-1.83(\mathrm{~m}, 4 \mathrm{H}), 1.26-$ $1.37(\mathrm{~m}, 19 \mathrm{H}), 0.90(\mathrm{t}, J=6.8 \mathrm{~Hz}, 2 \mathrm{H})$.

${ }^{13} \mathrm{C}$ NMR $\left(126 \mathrm{MHz} \mathrm{CDCl}_{3}\right) \delta: 144.0,135.9,134.6,131.2,130.9,129.2,127.0,126.8,74.3$, $39.1,31.9,29.6,29.6,29.6,29.5,29.5,29.3,25.8,22.7,14.1$.

Yield: $90 \%(0.0333 \mathrm{~g})$

$\mathrm{R}_{\mathrm{f}}:$ hex/EtOAc (1/0.2: 16\%), 0.60

HRMS (ESI): $m / z$ calculated for $\left[\mathrm{C}_{24} \mathrm{H}_{32} \mathrm{~S}\right]^{+}: 352.2225 ;\left[\mathrm{M}-\mathrm{H}_{2} \mathrm{O}\right]^{+}$found: 352.2227

The ee was determined by HPLC analysis on Chiralpak OD-H column, hexane:IPA = 99/1; flow rate $=0.9 \mathrm{~mL} / \mathrm{min}$; UV detection at $234 \mathrm{~nm} ; \mathrm{t}_{\mathrm{R}}(R)=18.27 \mathrm{~min}$ (major), $\mathrm{t}_{\mathrm{R}}(S)=19.33 \mathrm{~min}$ (minor), ee $=93 \%(R)$. HPLC chromatograms are shown below for the racemic standard (top) and enantioenriched product (bottom). 
rac-14b

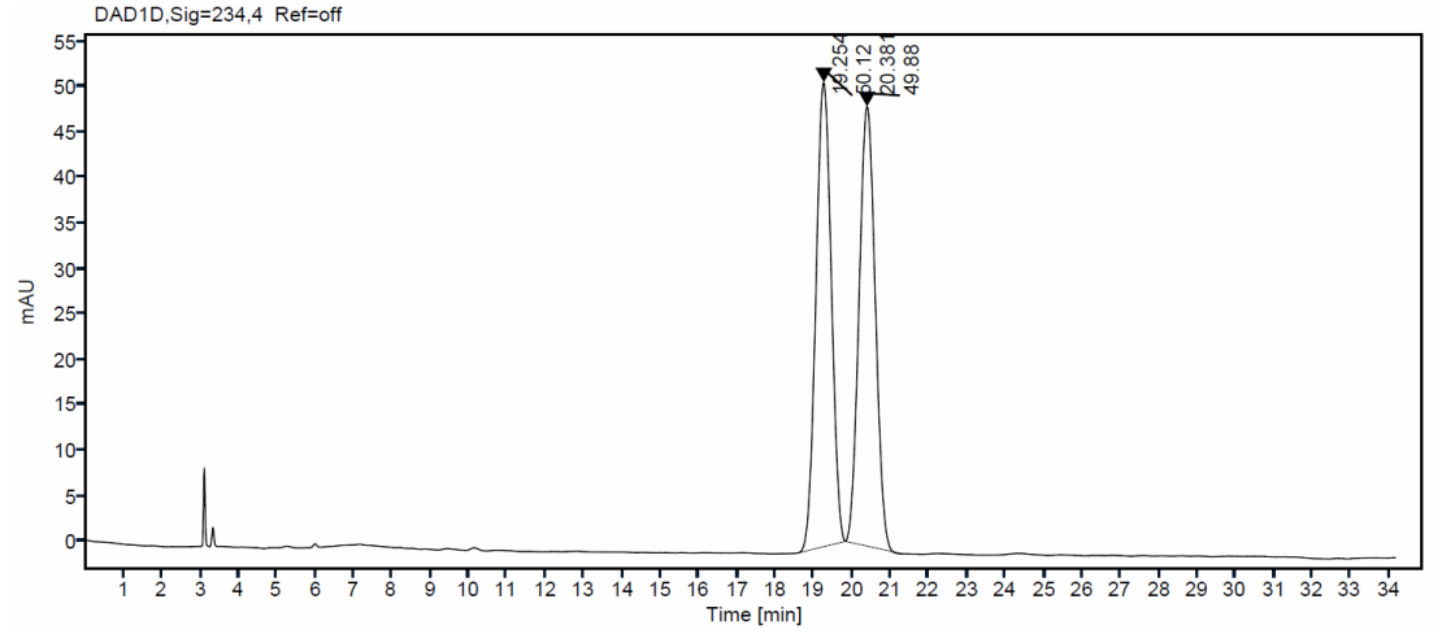

\section{Single Injection Report}

Agilent Technologies

Signal: $\quad$ DAD1D, $S i g=234,4$ Ref $=$ off

$\begin{array}{rrr}\text { RT [min] } & \text { Area } & \text { Area\% } \\ 19.254 & 1419.9098 & 50.1187 \\ 20.381 & 1413.1856 & 49.8813 \\ \text { Sum } & 2833.0954 & \end{array}$

$(R)-14 b$

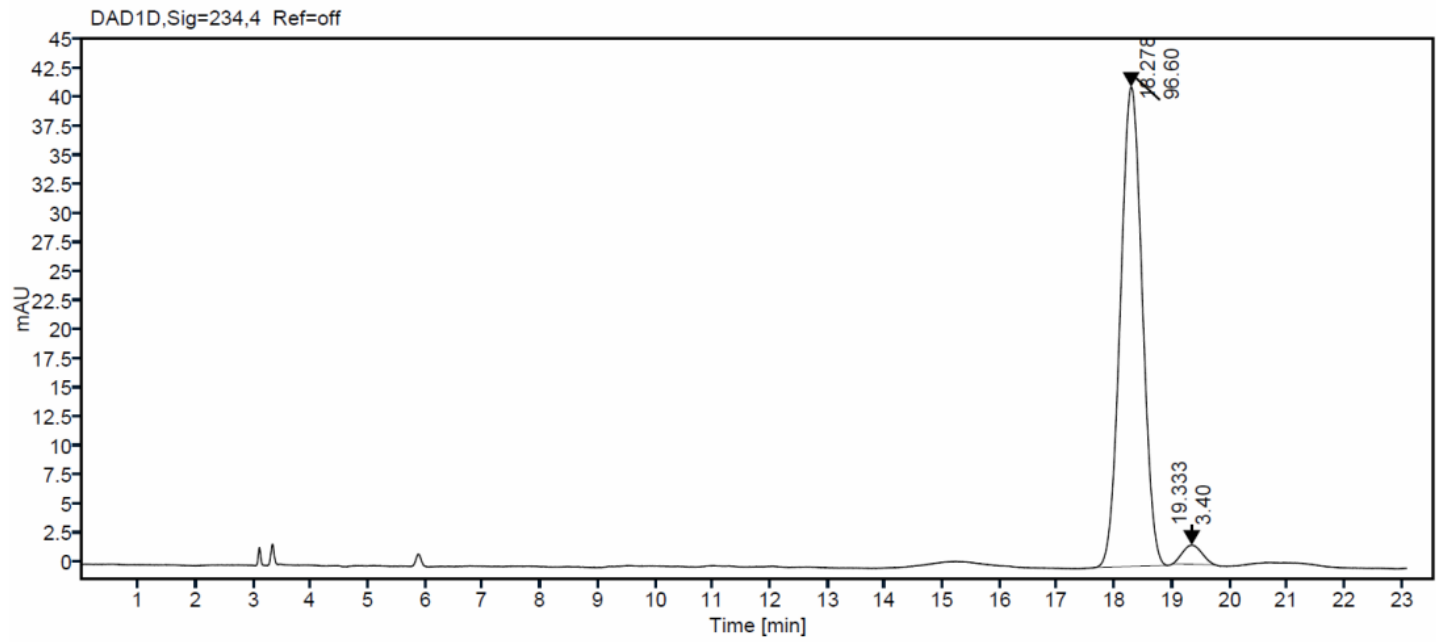

\section{Single Injection Report}

Signal:

DAD1D, Sig=234,4 Ref=off
RT [min]
18.278
19.333
Sum

Area
1085.146
38.1843
1123.3304

rea

123.3304
Area\%

96.6008

3.3992 
<smiles>CC(O)c1ccc(-c2cncnc2)cc1</smiles>

15b

Synthesized using Method A.

${ }^{1} \mathrm{H}$ NMR (500 MHz, $\left.\mathrm{CDCl}_{3}\right) \delta: 9.23(\mathrm{~s}, 1 \mathrm{H}), 8.98(\mathrm{~s}, 2 \mathrm{H}), 7.53-7.50(\mathrm{~m}, 4 \mathrm{H}), 5.03(\mathrm{q}, J=6.4 \mathrm{~Hz}$, $1 \mathrm{H}), 2.21(\mathrm{~s}, 1 \mathrm{H}), 1.58(\mathrm{~d}, J=6.5 \mathrm{~Hz}, 3 \mathrm{H})$.

${ }^{13} \mathrm{C}$ NMR $\left(126 \mathrm{MHz}_{\mathrm{CDCl}}\right)$ $)$ : 154.8, 147.3, 134.5, 129.6, 126.1, 126.1, 124.1, 70.1, 25.5.

Yield: $89 \%(0.0178 \mathrm{~g})$

$\mathrm{R}_{\mathrm{f}}: \mathrm{DCM} / \mathrm{MeOH}(1 / 0.04: 4 \%), 0.55$

HRMS (ESI): $m / z$ calculated for $\left[\mathrm{C}_{12} \mathrm{H}_{12} \mathrm{~N}_{2} \mathrm{O}\right]^{+}: 200.0950 ;[\mathrm{M}]^{+}$found: 200.0942

The ee was determined by HPLC analysis on Chiralpak OD-H column, hexane:IPA = 75/25;

flow rate $=1.0 \mathrm{~mL} / \mathrm{min}$; UV detection at $250 \mathrm{~nm} ; \mathrm{t}_{\mathrm{R}}(R)=6.41 \mathrm{~min}\left(\right.$ major), $\mathrm{t}_{\mathrm{R}}(S)=6.93$ (minor), ee $=98 \%(R)$. HPLC chromatograms are shown below for the racemic standard (top) and enantioenriched product (bottom). 
rac-15b

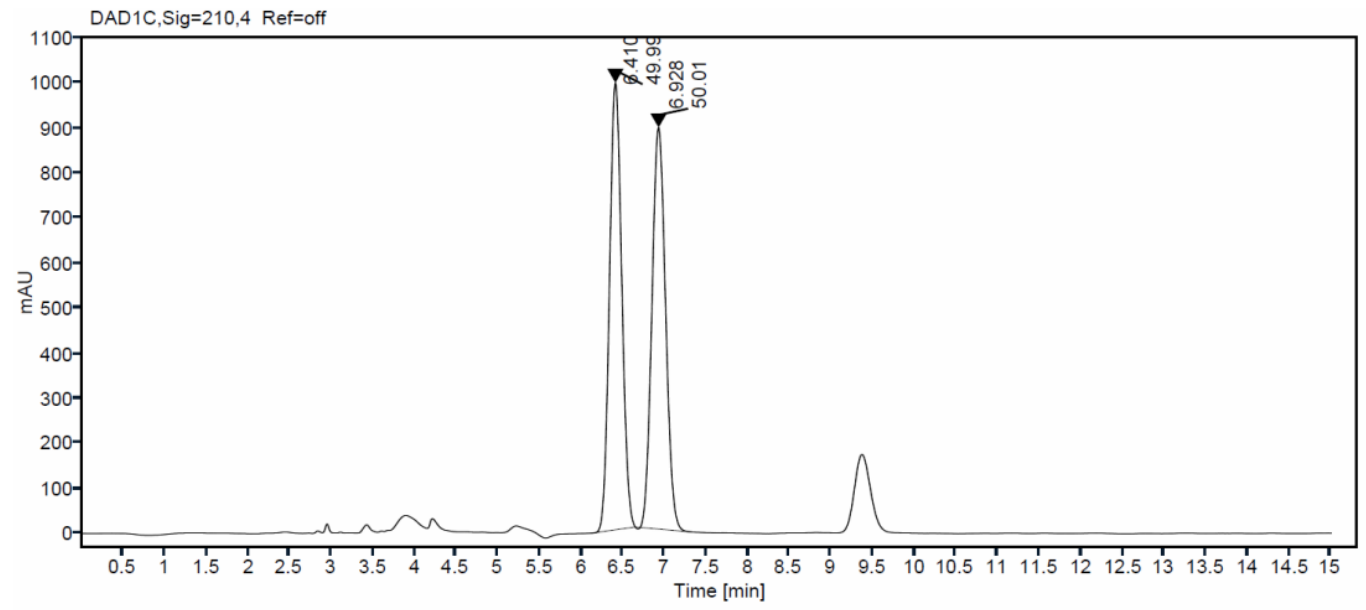

Single Injection Report

Agilent Technologies

Signal: $\quad$ DAD1C, $S i g=210,4$ Ref $=$ off

$\begin{array}{rrr}\text { RT [min] } & \text { Area } & \text { Area\% } \\ 6.410 & 10133.9716 & 49.9886 \\ 6.928 & 10138.5827 & 50.0114 \\ \text { Sum } & 20272.5543 & \end{array}$

$(R)-\mathbf{1 5 b}$

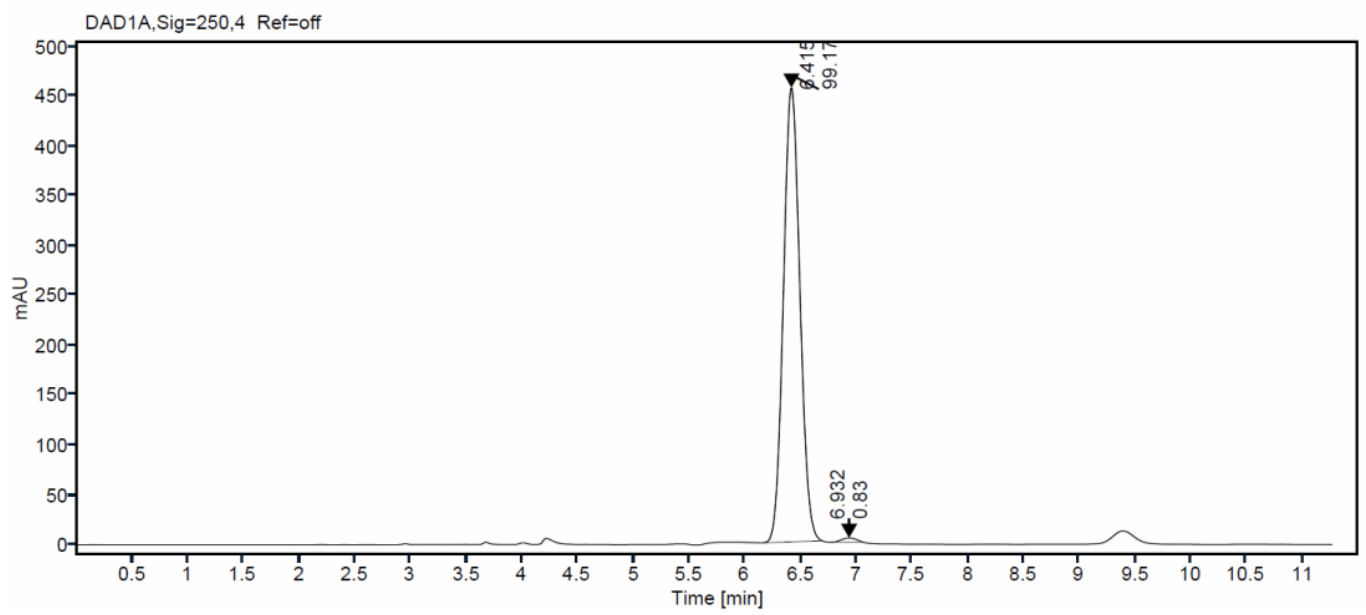

\section{Single Injection Report}

Signal: $\quad$ DAD1A,Sig $=250,4$ Ref $=$ off

$\begin{array}{rrr}\text { RT [min] } & \text { Area } & \text { Area\% } \\ 6.415 & 4684.2270 & 99.1721 \\ 6.932 & 39.1053 & 0.8279 \\ \text { Sum } & 4723.3323 & \end{array}$




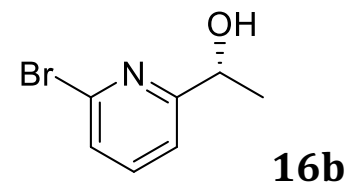

Synthesized using Method A.

${ }^{1} \mathrm{H} \mathrm{NMR}\left(500 \mathrm{MHz}, \mathrm{CDCl}_{3}\right) \delta 7.56(\mathrm{t}, J=7.7 \mathrm{~Hz}, 1 \mathrm{H}), 7.40(\mathrm{~d}, J=7.8 \mathrm{~Hz}, 1 \mathrm{H}), 7.30(\mathrm{~d}, J=7.6 \mathrm{~Hz}$, $1 \mathrm{H}), 4.89(\mathrm{p}, J=6.4 \mathrm{~Hz}, 1 \mathrm{H}), 3.44(\mathrm{~d}, J=5.1 \mathrm{~Hz}, 1 \mathrm{H}), 1.52(\mathrm{~d}, J=6.6 \mathrm{~Hz}, 3 \mathrm{H})$.

${ }^{13} \mathrm{C}$ NMR $\left(126 \mathrm{MHz}, \mathrm{CDCl}_{3}\right) \delta 165.18,141.12,139.15,126.58,118.49,69.12,24.07$.

Yield: 99\% (0.0198 g)

$\mathrm{R}_{\mathrm{f}}:$ hex/EtOAc (1/0.35: 26\%), 0.30

The ee was determined by HPLC analysis on Chiralpak Cell2 column, hexane:IPA $=97 / 3$; flow rate $=0.8 \mathrm{~mL} / \mathrm{min}$; UV detection at $234 \mathrm{~nm} ; \mathrm{t}_{\mathrm{R}}(S)=2.24 \mathrm{~min}$ (minor), $\mathrm{t}_{\mathrm{R}}(R)=2.90$ (major), ee $=93 \%(R)$. HPLC chromatograms are shown below for the racemic standard (top) and enantioenriched product (bottom). 
rac-16b

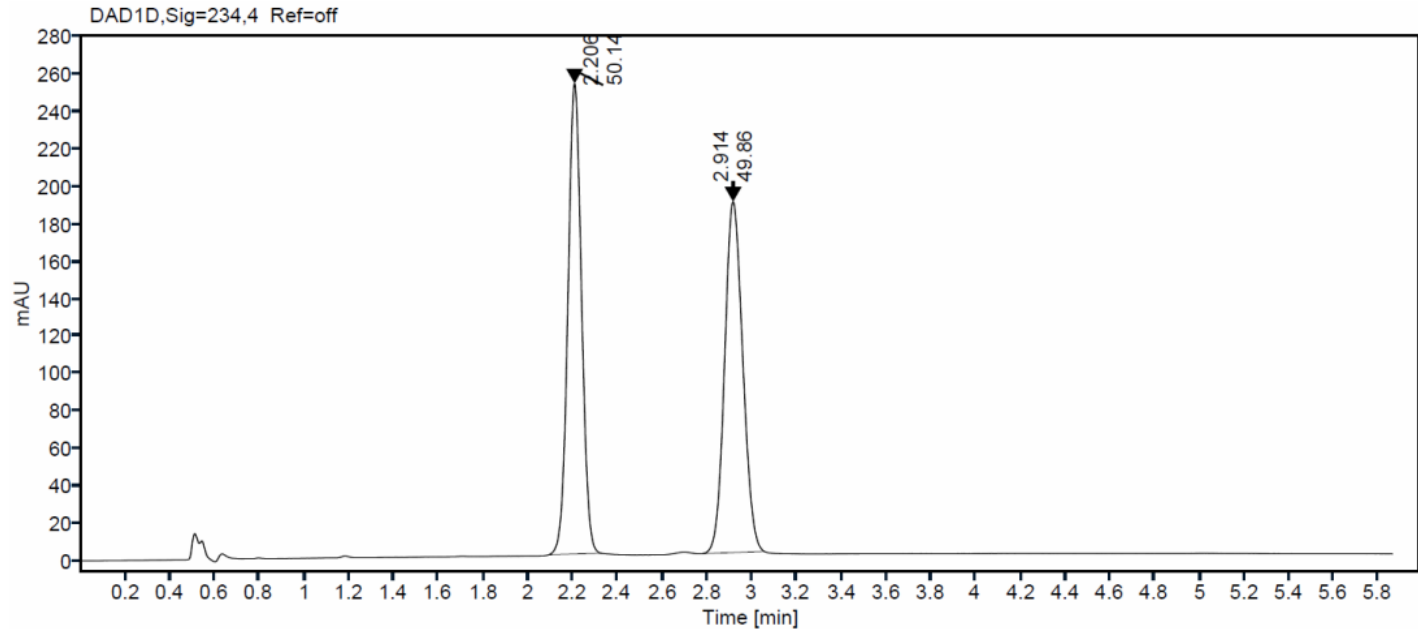

\section{Single Injection Report}

Signal: $\quad$ DAD1D, Sig=234,4 Ref=off

$\begin{array}{rrr}\text { RT [min] } & \text { Area } & \text { Area\% } \\ 2.206 & 1060.1190 & 50.1429 \\ 2.914 & 1054.0752 & 49.8571 \\ \text { Sum } & 2114.1943 & \end{array}$

(R)-16b

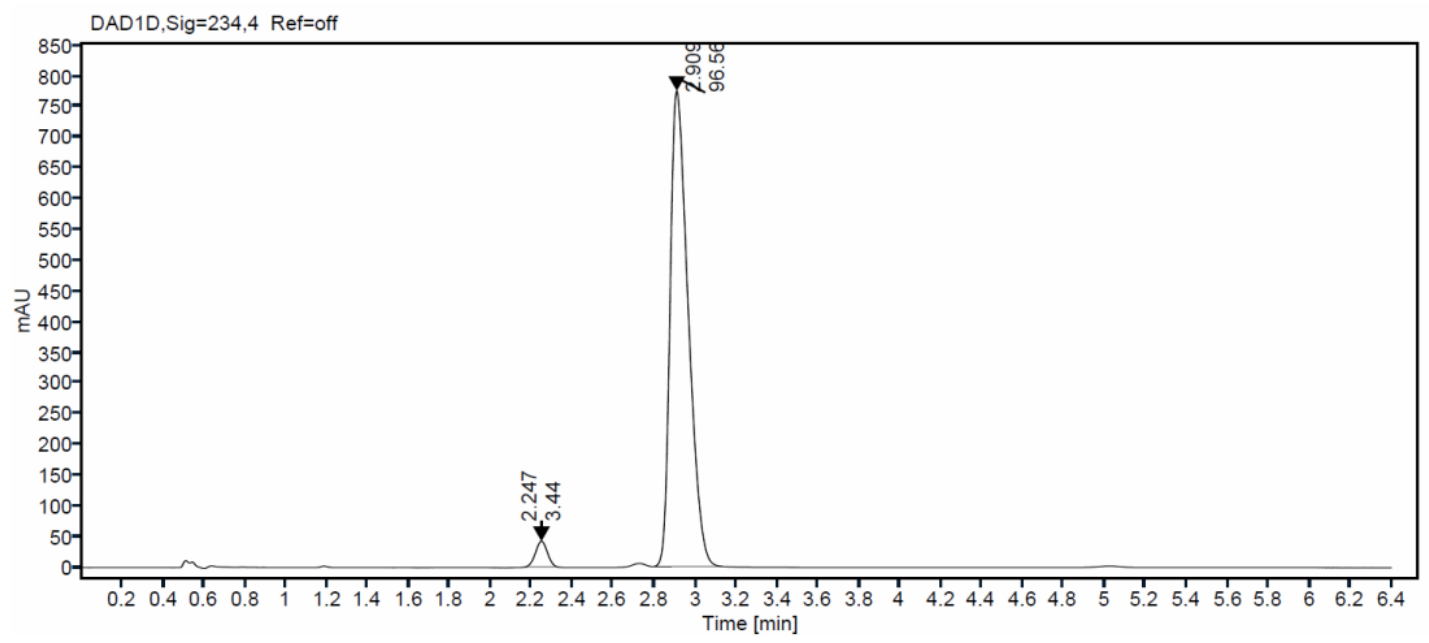

\section{Single Injection Report}

Signal: $\quad$ DAD1D, $\operatorname{Sig}=234,4$ Ref $=$ off

RT [min]

2.247

2.909

Sum
Area

169.0564

4749.1028

4918.1591
Area $\%$

3.4374

96.5626 


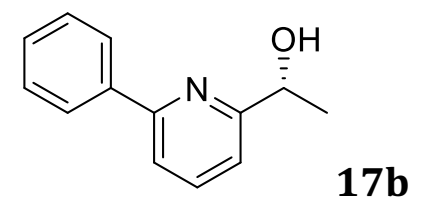

Prepared by Method B.

${ }^{1} \mathrm{H}$ NMR $\left(500 \mathrm{MHz}, \mathrm{CDCl}_{3}\right) \delta: 8.01-8.05(\mathrm{~m}, 2 \mathrm{H}), 7.77(\mathrm{t}, J=7.8 \mathrm{~Hz}, 1 \mathrm{H}), 7.65(\mathrm{~d}, J=7.8 \mathrm{~Hz}$, $1 \mathrm{H}), 7.49(\mathrm{~m}, 2 \mathrm{H}), 7.43(\mathrm{~m}, 1 \mathrm{H}), 7.20(\mathrm{~d}, J=7.7 \mathrm{~Hz}, 1 \mathrm{H}), 4.95(\mathrm{q}, J=6.5 \mathrm{~Hz}, 1 \mathrm{H}), 4.74(\mathrm{bs}, 1 \mathrm{H})$, $1.56(\mathrm{~d}, J=6.5 \mathrm{~Hz}, 3 \mathrm{H})$.

${ }^{13} \mathrm{C}$ NMR $\left(126 \mathrm{MHz}, \mathrm{CDCl}_{3}\right) \delta: 162.6,155.6,138.7,137.7,129.2,128.8,126.9,118.9,118.3$, $68.5,24.3$.

Yield: $81 \%$

$\mathrm{R}_{\mathrm{f}}:$ hex/EtOAc (1/0.33: 25\%), 0.26

HRMS (EI): $\mathrm{m} / \mathrm{z}$ calculated for $\left[\mathrm{C}_{13} \mathrm{H}_{13} \mathrm{NONa}\right]^{+}:$222.0895; [M] found: 222.0890

The ee was determined by HPLC analysis on Chiralpak AD-H column, hexane:IPA = 99/1; flow rate $=1 \mathrm{~mL} / \mathrm{min}$; UV detection at $250 \mathrm{~nm} ; \mathrm{t}_{\mathrm{R}}(R)=38.68 \mathrm{~min}$ (major), $\mathrm{t}_{\mathrm{R}}(S)=44.29 \mathrm{~min}$ (minor), ee: 96\%. HPLC chromatograms are shown below for the racemic standard (top) and enantioenriched product (bottom). 
$r a c-17 b$

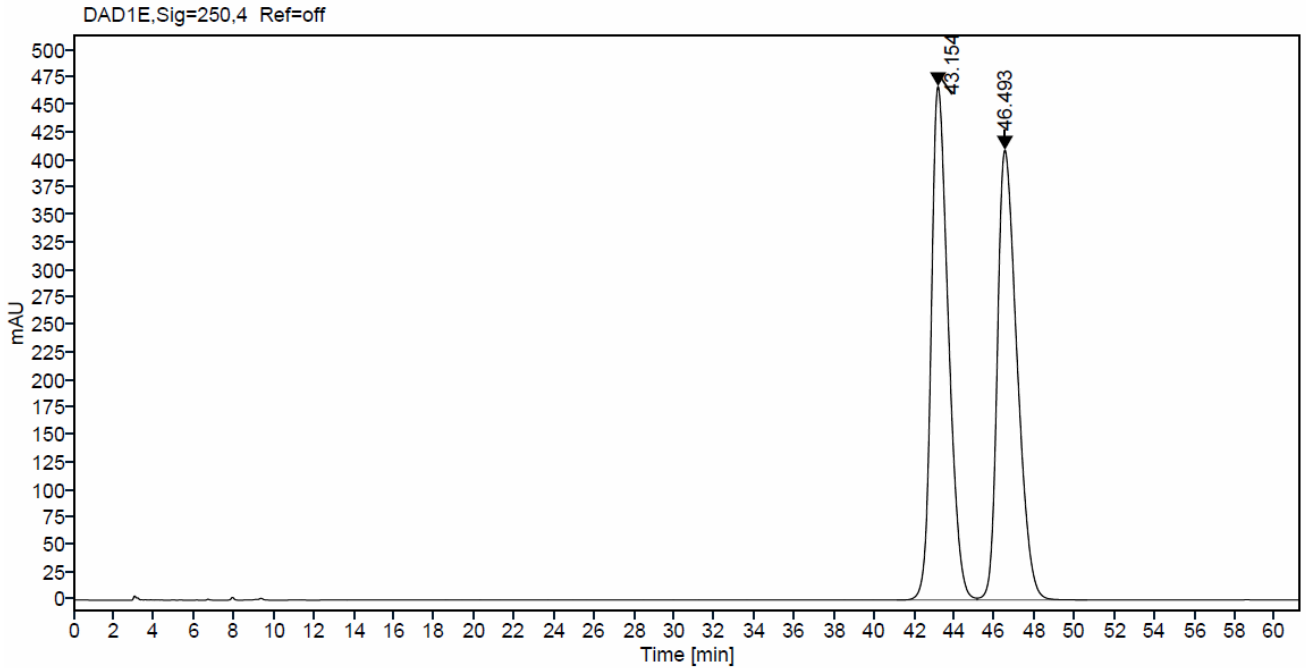

\section{Single Injection Report}

\begin{tabular}{rrr}
\multicolumn{1}{l}{$\begin{array}{l}\text { Signal: } \\
\text { RT [min] }\end{array}$} & $\begin{array}{r}\text { DAD1E, Sig }=250,4 \\
\text { Ref }=\text { off } \\
\text { Area } \%\end{array}$ \\
43.154 & 27836.4278 & 49.9475 \\
46.493 & 27894.9440 & 50.0525 \\
Sum & 55731.3718 &
\end{tabular}

$(R)-\mathbf{1 7 b}$

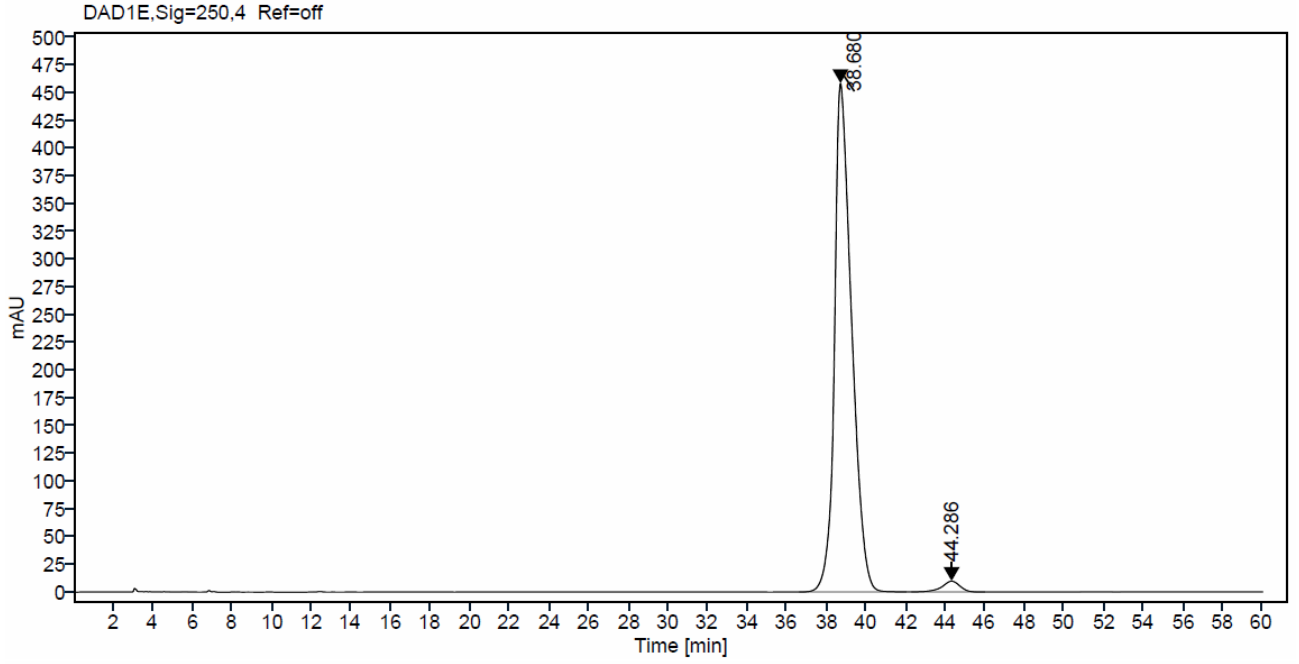

\section{Single Injection Report}

$\begin{array}{rrr}\text { Signal: } & \text { DAD1E, Sig=250,4 } & \text { Ref=off } \\ \text { RT [min] } & \text { Area } & \text { Area\% } \\ 38.680 & 27592.3693 & 97.8253 \\ 44.286 & 613.3787 & 2.1747 \\ \text { Sum } & 28205.7480 & \end{array}$




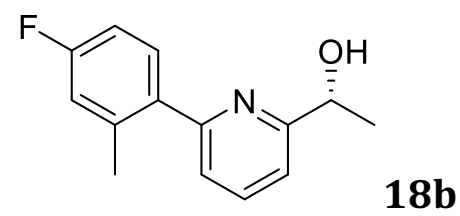

Synthesized using Method A.

${ }^{1} \mathrm{H}$ NMR $\left(500 \mathrm{MHz}, \mathrm{CDCl}_{3}\right) \delta: 7.77(\mathrm{t}, J=7.7 \mathrm{~Hz}, 1 \mathrm{H}), 7.40(\mathrm{dd}, J=8.4,6.0 \mathrm{~Hz}, 1 \mathrm{H}), 7.30(\mathrm{~d}, J=$ $7.7 \mathrm{~Hz}, 1 \mathrm{H}), 7.24(\mathrm{~d}, J=7.8 \mathrm{~Hz}, 1 \mathrm{H}), 6.97-7.23(\mathrm{~m}, 2 \mathrm{H}), 4.92-4.97(\mathrm{~m}, 1 \mathrm{H}), 4.40(\mathrm{~d}, J=5.0 \mathrm{~Hz}$, $1 \mathrm{H}), 2.39(\mathrm{~s}, 3 \mathrm{H}), 1.55(\mathrm{~d}, J=6.5 \mathrm{~Hz}, 3 \mathrm{H})$.

${ }^{13} \mathrm{C}$ NMR (126 MHz, $\mathrm{CDCl}_{3}$ ) $\delta: 163.6,162.3,161.6,157.5,138.6$ (d, $\left.J=7.56 \mathrm{~Hz}\right), 137.2,131.4$ (d, $J=8.5 \mathrm{~Hz}), 122.5,117.8,117.4(\mathrm{~d}, J=21.1 \mathrm{~Hz}), 112.8(\mathrm{~d}, J=21.2 \mathrm{~Hz}), 68.7,24.4,20.7$.

Yield: 99\% (0.0228 g)

$\mathrm{R}_{\mathrm{f}}:$ hex/EtOAc (1/0.35: 26\%), 0.25

HRMS (ESI): $m / z$ calculated for $\left[\mathrm{C}_{14} \mathrm{H}_{14} \mathrm{FNONa}\right]^{+}: 254.0957 ;[\mathrm{M}+\mathrm{Na}]^{+}$found: 254.0957

The ee was determined by HPLC analysis on Chiralpak Cell2 column, hexane:IPA = 98/2; flow rate $=0.7 \mathrm{~mL} / \mathrm{min}$; UV detection at $250 \mathrm{~nm} ; \mathrm{t}_{\mathrm{R}}(S)=2.53 \mathrm{~min}$ (minor), $\mathrm{t}_{\mathrm{R}}(R)=2.78$ (major), ee $=95 \%(R)$. HPLC chromatograms are shown below for the racemic standard (top) and enantioenriched product (bottom). 
$r a c-\mathbf{1 8 b}$

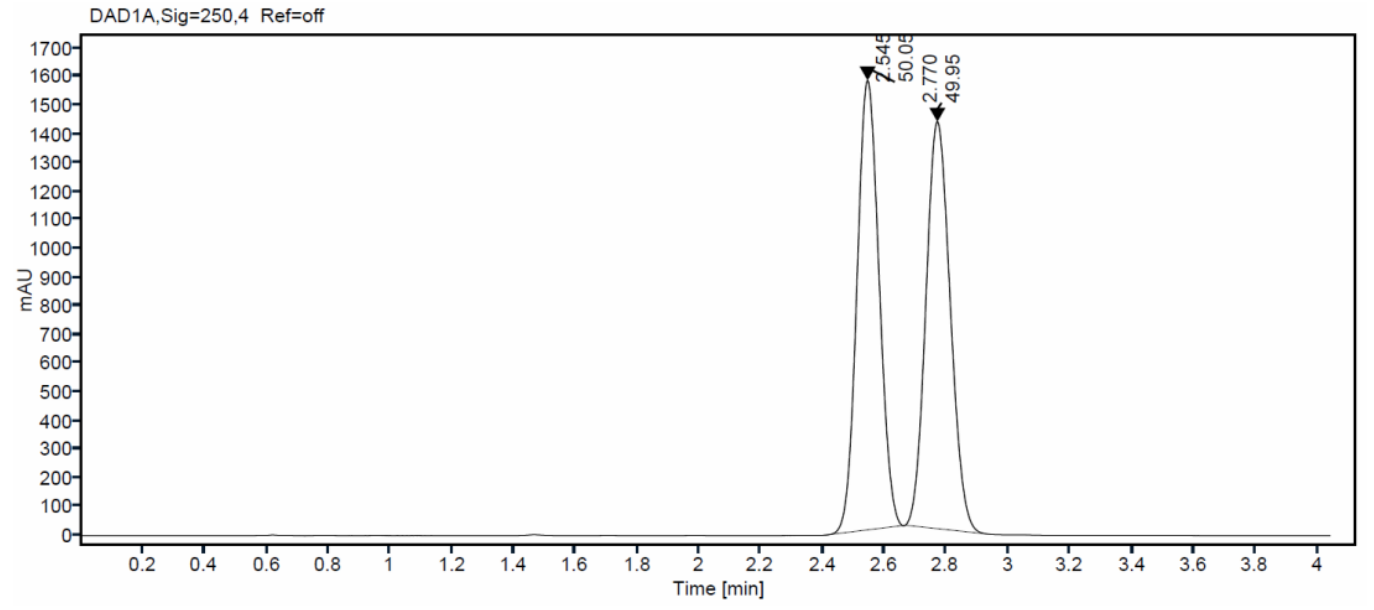

\section{Single Injection Report}

\begin{tabular}{lrr} 
Signal: & \multicolumn{1}{c}{ DAD1A,Sig=250,4 Ref=off } \\
RT [min] & Area & Area\% \\
2.545 & 7774.7757 & 50.0526 \\
2.770 & 7758.4275 & 49.9474 \\
Sum & 15533.2033 &
\end{tabular}

\section{$(R)-\mathbf{1 8 b}$}

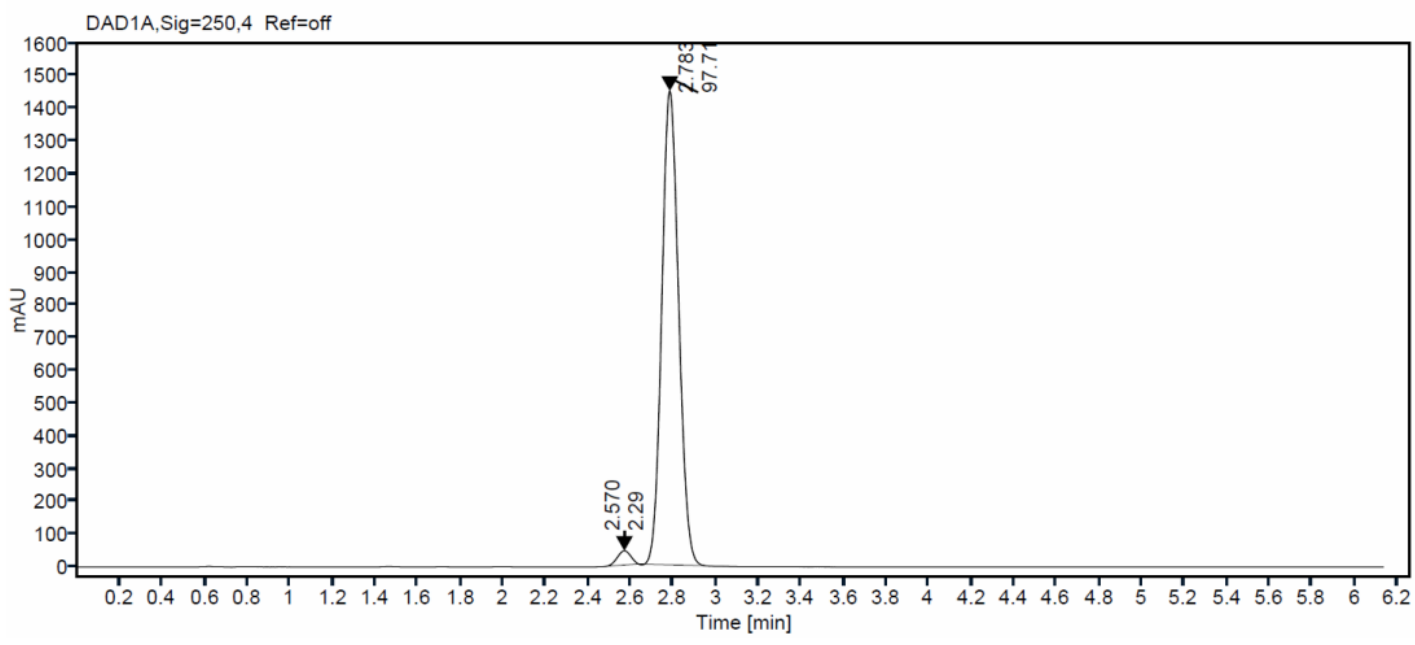

\section{Single Injection Report}

Signal:

DAD1A,Sig=250,4 Ref=off

\section{RT [min]}

2.570

2.783

Sum
Area

186.5842

7957.5441

8144.1284
Area $\%$

2.2910

97.7090 


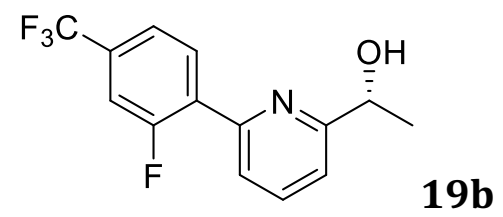

Synthesized using Method A.

${ }^{1} \mathrm{H} \mathrm{NMR}\left(500 \mathrm{MHz}, \mathrm{CDCl}_{3}\right) \delta: 8.18(\mathrm{t}, J=7.8 \mathrm{~Hz}, 1 \mathrm{H}), 7.83(\mathrm{t}, J=7.7 \mathrm{~Hz}, 1 \mathrm{H}), 7.76(\mathrm{~d}, J=7.7 \mathrm{~Hz}$, $1 \mathrm{H}), 7.56(\mathrm{~d}, J=8.1 \mathrm{~Hz}, 1 \mathrm{H}), 7.46(\mathrm{~d}, J=11.0 \mathrm{~Hz}, 1 \mathrm{H}), 7.33(\mathrm{~d}, J=7.7 \mathrm{~Hz}, 1 \mathrm{H}), 4.95-5.00(\mathrm{~m}$, $1 \mathrm{H}), 4.32(\mathrm{~d}, J=4.4 \mathrm{~Hz}, 1 \mathrm{H}), 1.58(\mathrm{~d}, J=6.6 \mathrm{~Hz}, 3 \mathrm{H})$.

${ }^{13} \mathrm{C}$ NMR $\left(126 \mathrm{MHz}, \mathrm{CDCl}_{3}\right) \delta: 163.28,161.09,159.08,150.10$ (d, $\left.J=2.5 \mathrm{~Hz}\right), 137.53,131.74$ $(\mathrm{d}, J=3.2 \mathrm{~Hz}), 123.14(\mathrm{~d}, J=9.8 \mathrm{~Hz}), 121.26(\mathrm{q}, J=3.9 \mathrm{~Hz}), 119.41,113.85(\mathrm{dq}, J=26.5,3.8$ $\mathrm{Hz}), 68.80,24.27$.

Yield: $99 \%(0.0282 \mathrm{~g})$

$\mathrm{R}_{\mathrm{f}}:$ hex/EtOAc (1/0.35: 26\%), 0.20

HRMS (ESI): $m / z$ calculated for $\left[\mathrm{C}_{14} \mathrm{H}_{10} \mathrm{~F}_{4} \mathrm{NO}\right]^{+}: 284.0699 ;[\mathrm{M}-\mathrm{H}]^{+}$found: 284.0691

The ee was determined by HPLC analysis on Chiralpak Cell2 column, hexane:IPA $=97 / 3$; flow rate $=0.8 \mathrm{~mL} / \mathrm{min} ; \mathrm{UV}$ detection at $234 \mathrm{~nm} ; \mathrm{t}_{\mathrm{R}}(S)=1.27 \min \left(\right.$ minor), $\mathrm{t}_{\mathrm{R}}(R)=1.45 \mathrm{~min}$ (major), ee $=93 \%(R)$. HPLC chromatograms are shown below for the racemic standard (top) and enantioenriched product (bottom). 
rac-19b

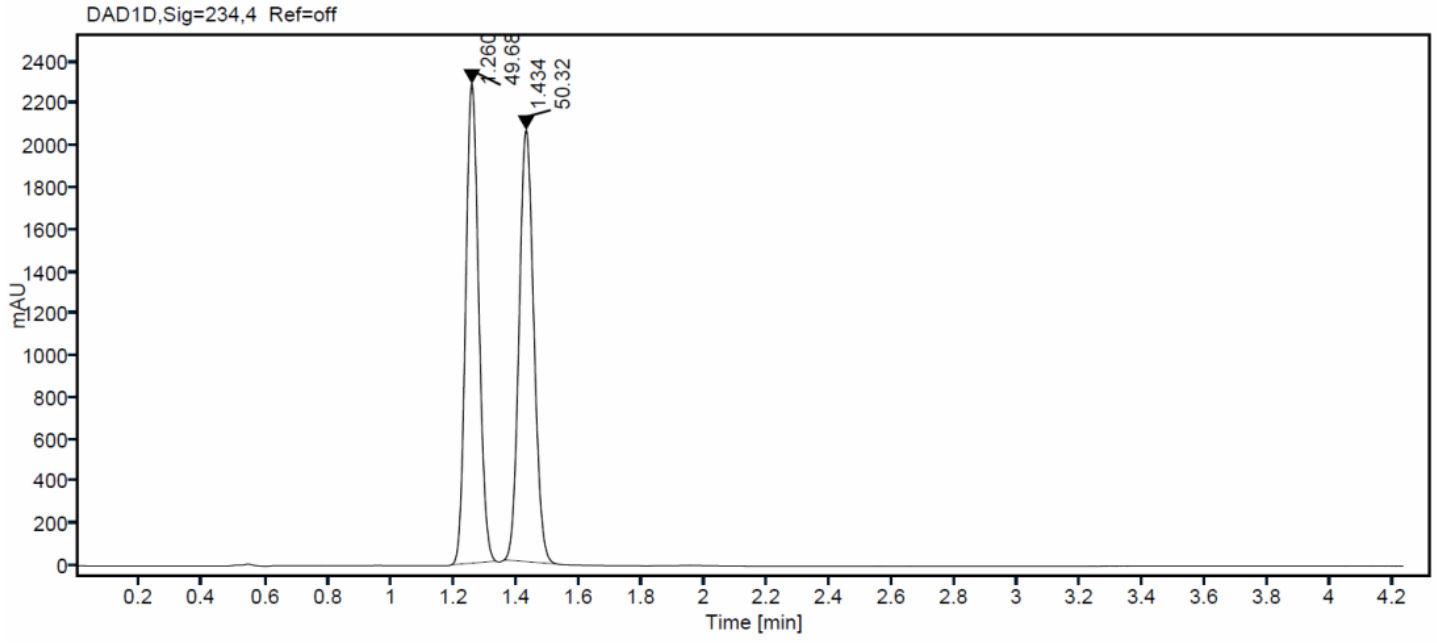

\section{Single Injection Report}

\section{Agilent Technologies}

Signal: $\quad$ DAD1D, Sig $=234,4$ Ref $=$ off

$\begin{array}{rrr}\mathbf{R T} \text { [min] } & \text { Area } & \text { Area\% } \\ 1.260 & 6626.5961 & 49.6788 \\ 1.434 & 6712.2740 & 50.3212 \\ \text { Sum } & 13338.8701 & \end{array}$

(R)-19b

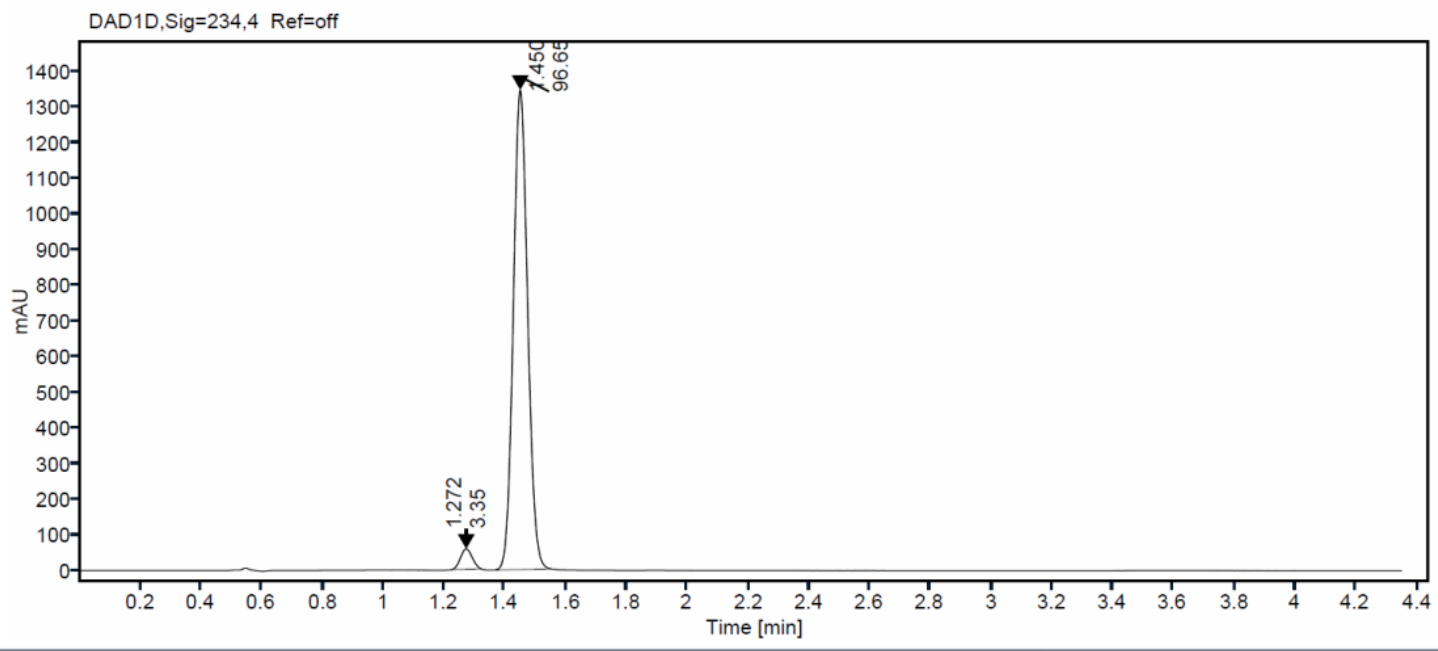

\section{Single Injection Report}

Signal: $\quad$ DAD1D, $S i g=234,4$ Ref $=$ off RT [min]

$$
\begin{array}{r}
1.272 \\
1.450 \\
\text { Sum }
\end{array}
$$

Area

152.9542

4407.6474

4560.6016
Area $\%$

3.3538

96.6462 


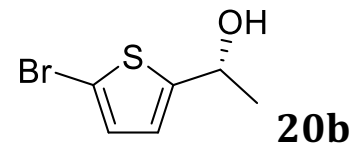

Synthesized using Method A.

${ }^{1} \mathrm{H}$ NMR $\left(500 \mathrm{MHz}, \mathrm{CDCl}_{3}\right) \delta: 6.90(\mathrm{~d}, J=3.7 \mathrm{~Hz}, 1 \mathrm{H}), 6.72(\mathrm{~d}, J=3.7 \mathrm{~Hz}, 1 \mathrm{H}), 5.02-5.03(\mathrm{~m}$, $1 \mathrm{H}), 2.28(\mathrm{~s}, 1 \mathrm{H}), 1.56(\mathrm{~d}, J=6.4 \mathrm{~Hz}, 3 \mathrm{H})$.

${ }^{13} \mathrm{C} \mathrm{NMR}\left(126 \mathrm{MHz}^{\mathrm{CDCl}} 3\right) \delta: 151.5,129.4,123.4,111.3,66.5,25.1$.

Yield: 53\% (0.0108 g)

$\mathrm{R}_{\mathrm{f}}:$ hex/EtOAc (1/0.2: 16\%), 0.30

The ee was determined by HPLC analysis on Chiralpak OD-H column, hexane:IPA $=98 / 2$; flow rate $=1.0 \mathrm{~mL} / \mathrm{min}$; UV detection at $254 \mathrm{~nm}$; $\mathrm{t}_{\mathrm{R}}(S)=15.47 \mathrm{~min}(\operatorname{minor}), \mathrm{t}_{\mathrm{R}}(R)=17.02 \mathrm{~min}$ (major), ee $=96 \%(R)$. HPLC chromatograms are shown below for the racemic standard (top) and enantioenriched product (bottom). 


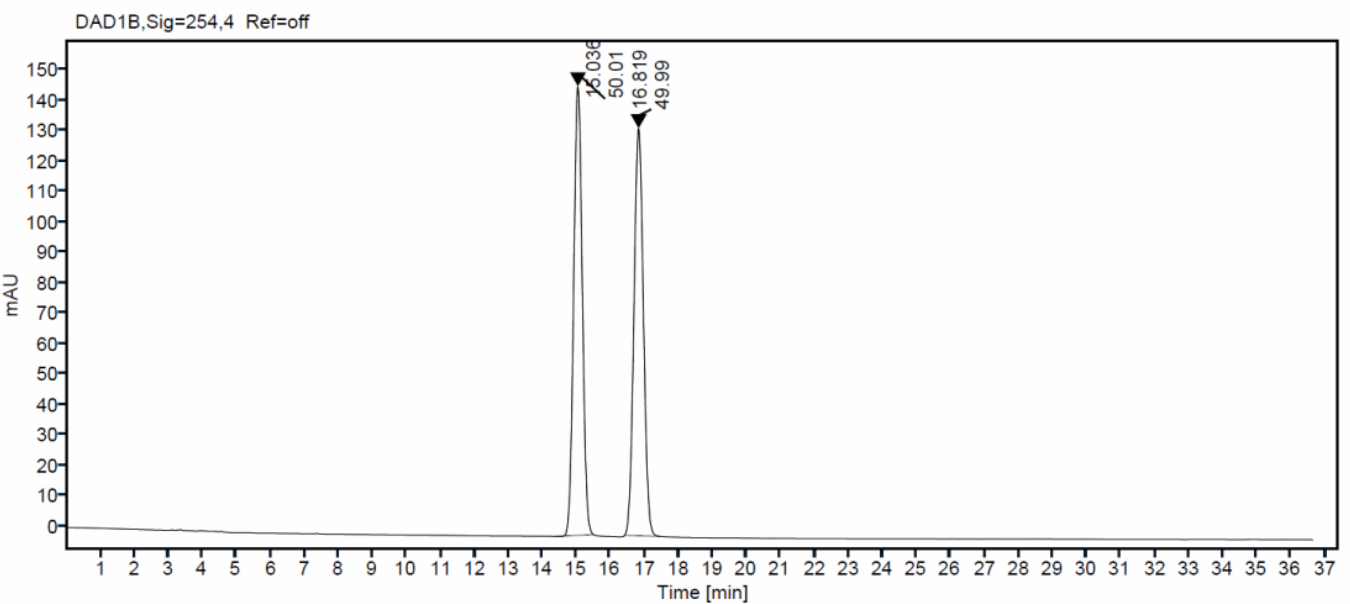

\section{Single Injection Report}

\section{Agilent Technologies}

Signal:

DAD1B, Sig=254,4 Ref=off
RT [min]

$\begin{array}{rr}\text { Area } \\ 15.036 & 2586.6069 \\ 16.819 & 2585.4195 \\ \text { Sum } & 5172.0264\end{array}$

$(R)-\mathbf{2 0 b}$

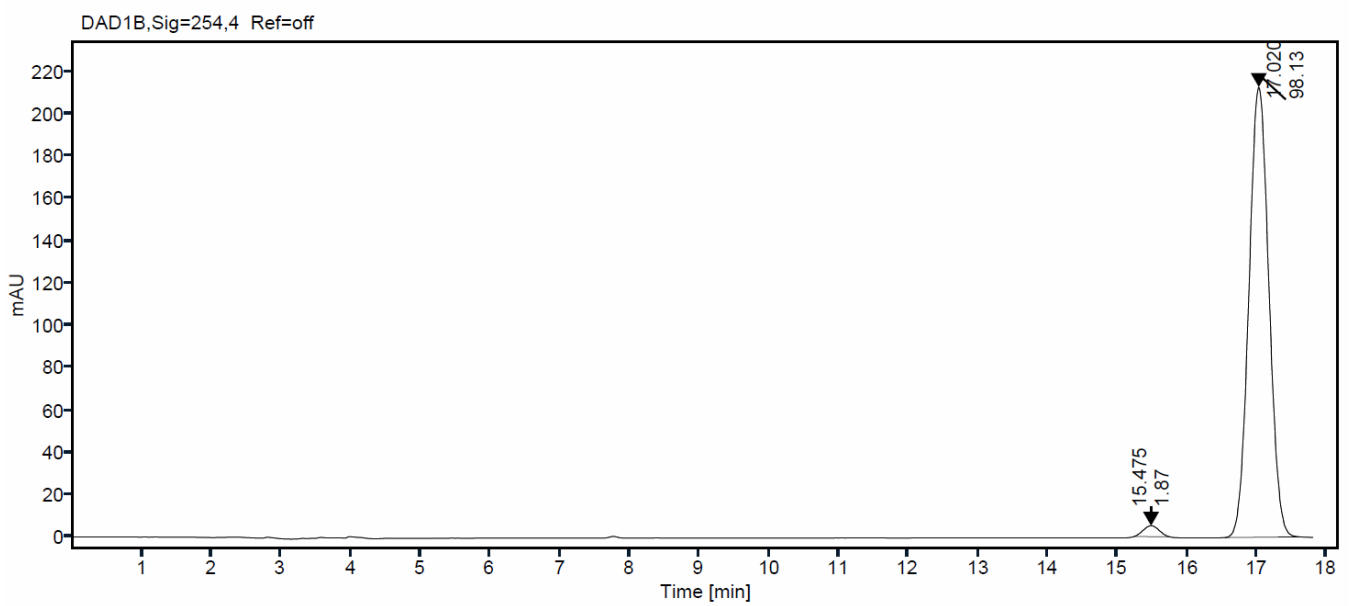

\section{Single Injection Report}

Signal:

DAD1B,Sig=254,4 Ref=off

RT [min]

15.475
17.020

Sum
Area

80.8173

4230.8299

4311.6472
Area $\%$

50.0115

49.9885 


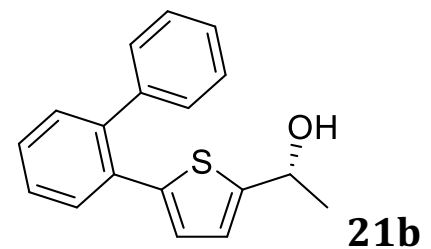

Synthesized using Method A.

${ }^{1} \mathrm{H}$ NMR $\left(500 \mathrm{MHz}, \mathrm{CDCl}_{3}\right) \delta: 7.57-7.54(\mathrm{~m}, 1 \mathrm{H}), 7.40-7.38(\mathrm{~m}, 3 \mathrm{H}), 7.32(\mathrm{~d}, J=12.8 \mathrm{~Hz}, 3 \mathrm{H})$, 7.26-7.28 (m, 2H), $6.74(\mathrm{dd}, J=3.6,0.7 \mathrm{~Hz}, 1 \mathrm{H}), 6.50(\mathrm{~d}, J=3.6 \mathrm{~Hz}, 1 \mathrm{H}), 5.10-5.03(\mathrm{~m}, 1 \mathrm{H})$, $2.00(\mathrm{~s}, 1 \mathrm{H}), 1.56(\mathrm{~d}, J=6.4 \mathrm{~Hz}, 3 \mathrm{H})$.

${ }^{13} \mathrm{C}$ NMR $\left(126 \mathrm{MHz}, \mathrm{CDCl}_{3}\right) \delta: 149.6,142.3,141.5,140.8,133.1,130.8,130.4,129.6,128.0$, $127.7,127.6,127.0,126.6,123.2,66.3,25.0$.

Yield: $52 \%(0.0145 \mathrm{~g})$

$\mathrm{R}_{\mathrm{f}}:$ hex/EtOAc (1/0.2: 16\%), 0.30

HRMS (ESI): $m / z$ calculated for $\left[\mathrm{C}_{18} \mathrm{H}_{14} \mathrm{~S}\right]^{+}: 262.0816$; [M- $\left.\mathrm{H}_{2} \mathrm{O}\right]^{+}$found: 262.0817

The ee was determined by HPLC analysis on Chiralpak OD-H column, hexane:IPA $=98 / 2$; flow rate $=0.7 \mathrm{~mL} / \mathrm{min}$; $\mathrm{UV}$ detection at $220 \mathrm{~nm} ; \mathrm{t}_{\mathrm{R}}(R)=26.11 \mathrm{~min}$ (major), ee $=100 \%(R)$. HPLC chromatograms are shown below for the racemic standard (top) and enantioenriched product (bottom). 
rac-21b

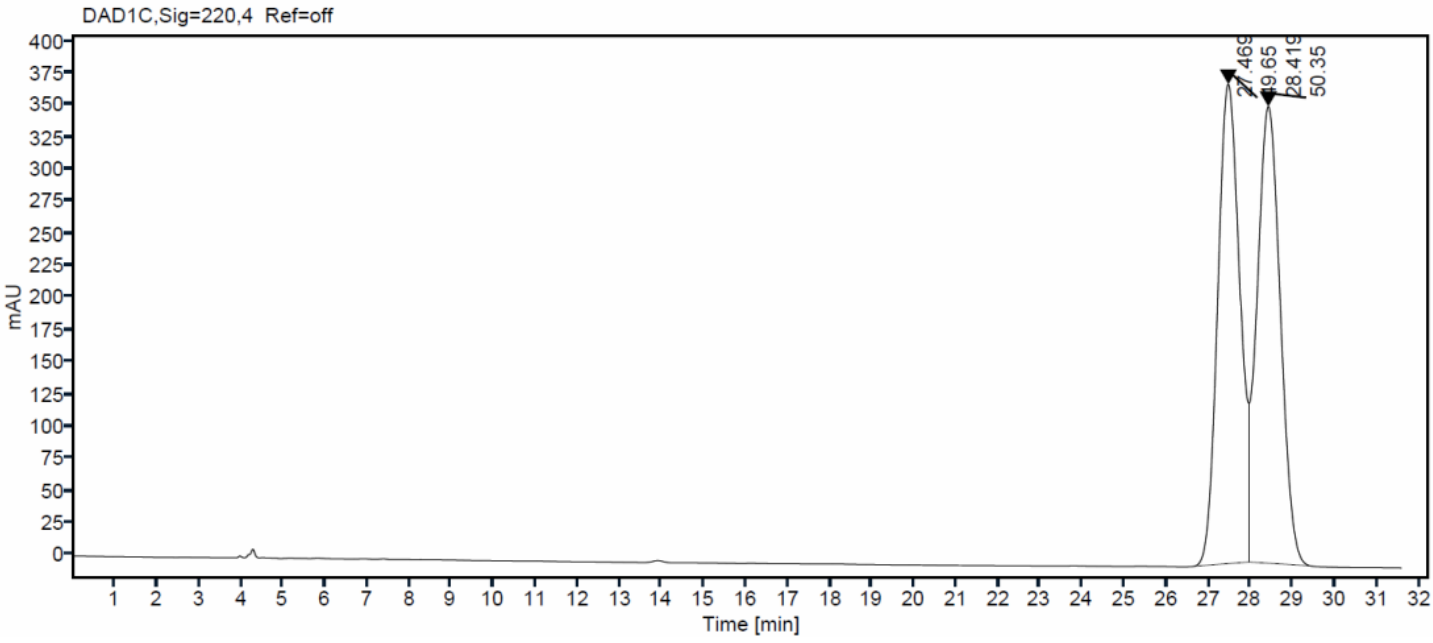

\section{Single Injection Report}

\section{Agilent Technologies}

Signal: $\quad$ DAD1C,Sig $=220,4$ Ref $=$ off

$\begin{array}{rrr}\text { RT [min] } & \text { Area } & \text { Area\% } \\ 27.469 & 13542.7461 & 49.6483 \\ 28.419 & 13734.5956 & 50.3517 \\ \text { Sum } & 27277.3417 & \end{array}$

$(R)-\mathbf{2 1 b}$

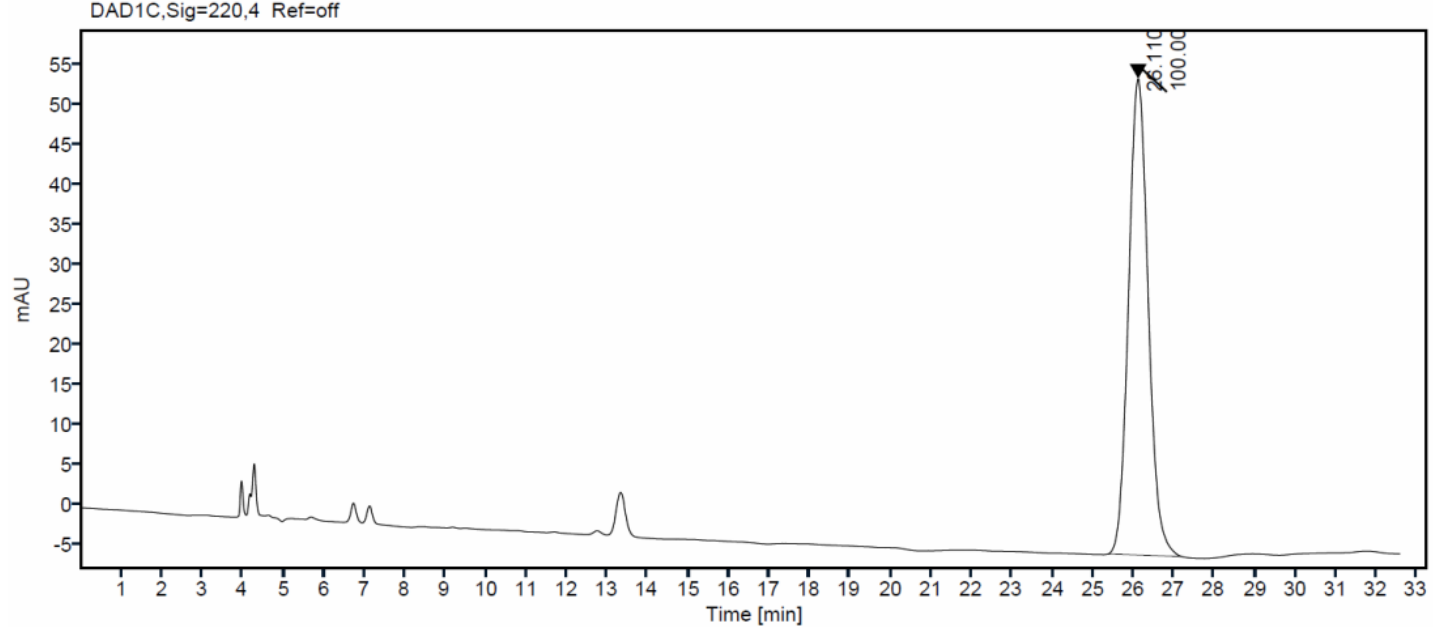

\section{Single Injection Report}

Signal: $\quad$ DAD1C,Sig $=220,4$ Ref $=$ off

$\begin{array}{rrr}\text { RT [min] } & \text { Area } & \text { Area\% } \\ 26.110 & 2013.8954 & 100.0000 \\ \text { Sum } & 2013.8954 & \end{array}$




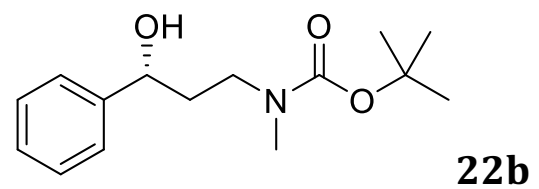

Prepared by Method B.

${ }^{1} \mathrm{H}$ NMR (500 MHz, MeOD) $\delta: 7.37-7.29(\mathrm{~m}, 4 \mathrm{H}), 7.23(\mathrm{~m}, 1 \mathrm{H}), 4.61(\mathrm{t}, J=6.5 \mathrm{~Hz}, 1 \mathrm{H}), 3.40-$ $3.21(\mathrm{bm}, 2 \mathrm{H}), 2.83(\mathrm{~s}, 3 \mathrm{H}), 1.93(\mathrm{bm}, 2 \mathrm{H}), 1.42$ (bs, 9H).

${ }^{13} \mathrm{C}$ NMR (126 MHz, MeOD) $\delta$ : 156.3 (b), 144.6, 128.0, 127.0, 125.5, 79.5, 71.3, 45.6 (b), 36.8 (b), 33.4 (b), 27.3.

Yield: $73 \%$

$\mathrm{R}_{\mathrm{f}}:$ hex/EtOAc (1/0.33: 25\%), 0.18

HRMS (ESI): $m / z$ calculated for $\left[\mathrm{C}_{15} \mathrm{H}_{23} \mathrm{NO}_{3} \mathrm{Na}\right]^{+}: 288.1576$; [M] $]^{+}$found: 288.1573

The ee was determined by HPLC analysis on Chiralpak OD-H column, hexane:IPA = 95/5; flow rate $=1 \mathrm{~mL} / \mathrm{min}$; UV detection at $210 \mathrm{~nm} ; \mathrm{t}_{\mathrm{R}}(R)=7.70 \mathrm{~min}$ (major), $\mathrm{t}_{\mathrm{R}}(S)=8.84 \mathrm{~min}$ (minor), ee: 93\%. HPLC chromatograms are shown below for the racemic standard (top) and enantioenriched product (bottom). 
$r a c-22 b$

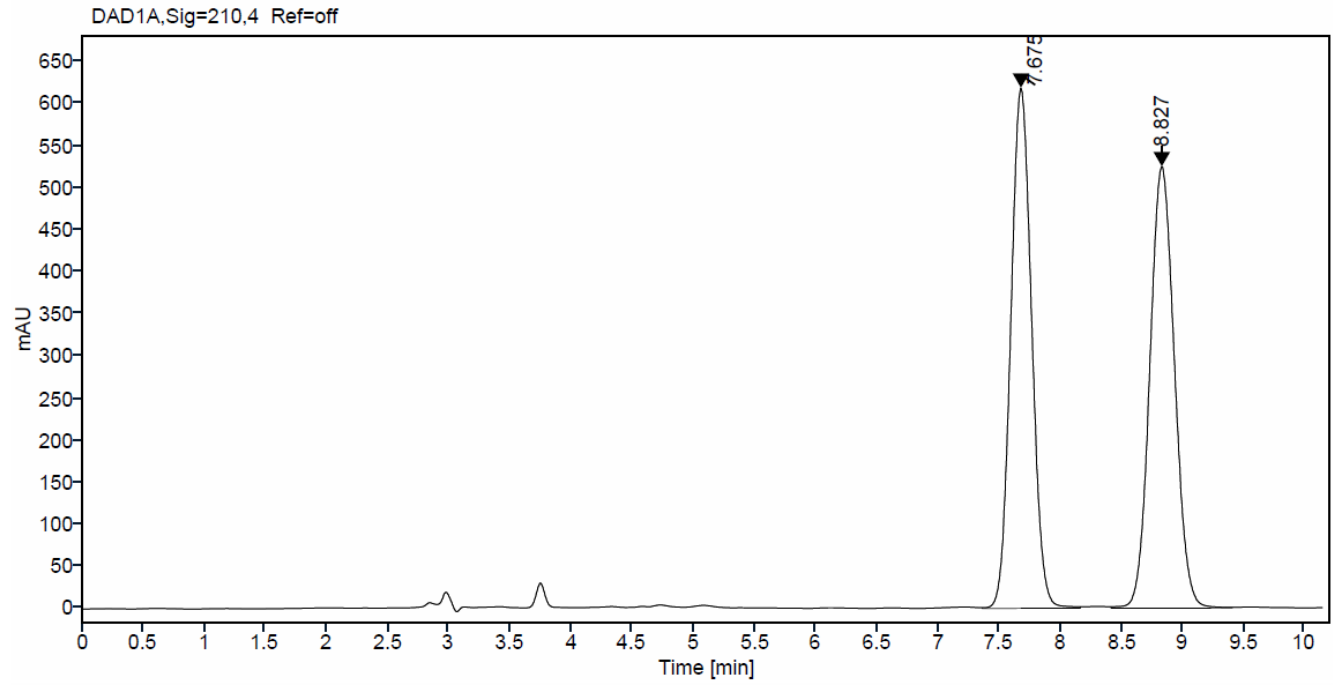

\section{Single Injection Report}

Signal: $\quad$ DAD1A,Sig=210,4 Ref=off

$\begin{array}{rrr}\text { RT [min] } & \text { Area } & \text { Area\% } \\ 7.675 & 7316.4506 & 49.9298 \\ 8.827 & 7337.0192 & 50.0702 \\ \text { Sum } & 14653.4698 & \end{array}$

$(R)-22 \mathbf{b}$

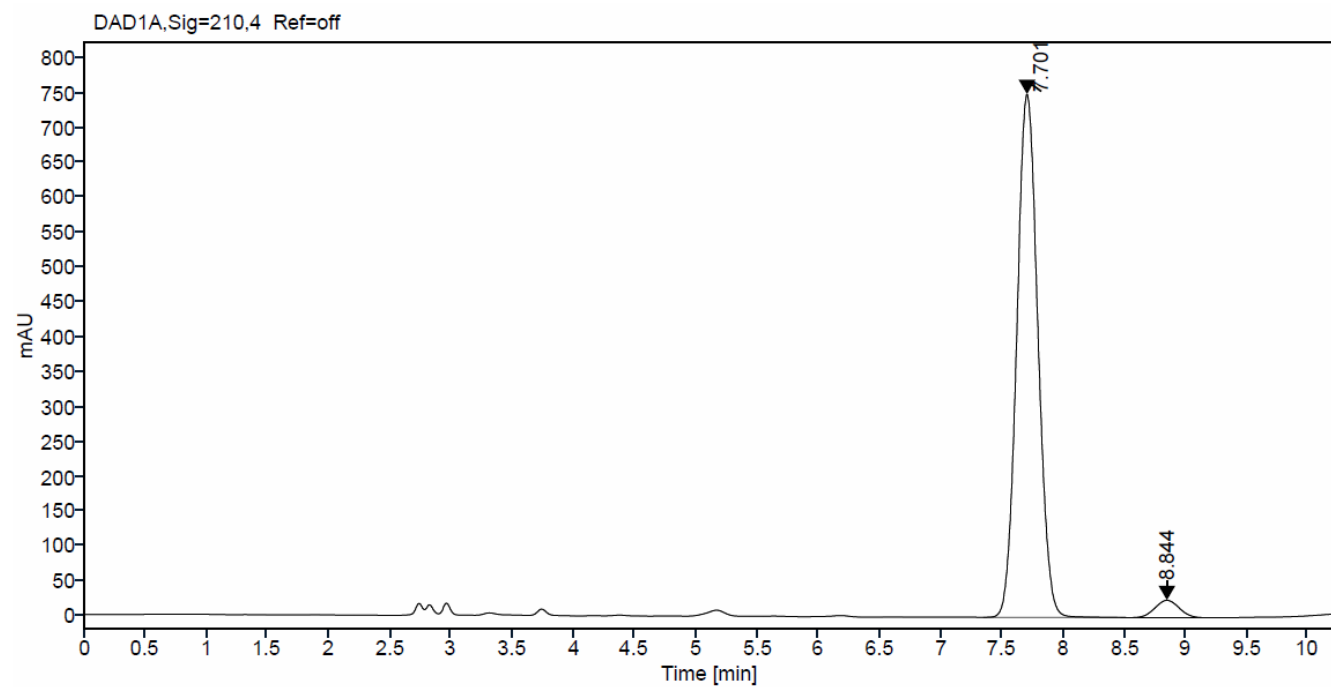

\section{Single Injection Report}

\begin{tabular}{rrr}
\multicolumn{1}{l}{$\begin{array}{l}\text { Signal: } \\
\text { RT } \text { [min] }\end{array}$} & Area & Area\% \\
7.701 & 8970.2880 & 96.3396 \\
8.844 & 340.8257 & 3.6604 \\
Sum & 9311.1137 &
\end{tabular}




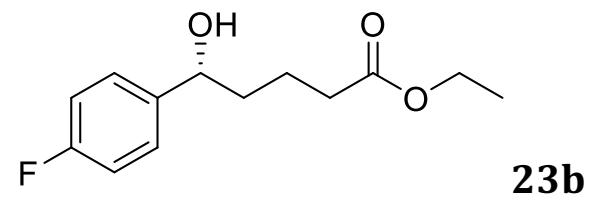

Prepared by Method B.

${ }^{1} \mathrm{H} \mathrm{NMR}\left(500 \mathrm{MHz}, \mathrm{CDCl}_{3}\right) \delta: 7.31(\mathrm{~m}, 2 \mathrm{H}), 7.02(\mathrm{~m}, 2 \mathrm{H}), 4.67(\mathrm{bs}, 1 \mathrm{H}), 4.11(\mathrm{q}, J=7.1 \mathrm{~Hz}, 2 \mathrm{H})$, $2.32(\mathrm{~m}, 2 \mathrm{H}), 1.98(\mathrm{~d}, J=2.8 \mathrm{~Hz}, 1 \mathrm{H}), 1.84-1.59(\mathrm{~m}, 4 \mathrm{H}), 1.24(\mathrm{t}, J=7.1 \mathrm{~Hz}, 3 \mathrm{H})$.

${ }^{13} \mathrm{C}$ NMR $\left(126 \mathrm{MHz} \mathrm{CDCl}_{3}\right) \delta: 173.5,163.2,161.2,140.2(\mathrm{~d}, J=3.1 \mathrm{~Hz}), 127.5(\mathrm{~d}, J=8.1 \mathrm{~Hz})$, $115.3(\mathrm{~d}, J=21.2 \mathrm{~Hz}), 73.5,60.4,38.5,33.9,21.1,14.2$.

Yield: $63 \%$

$\mathrm{R}_{\mathrm{f}}:$ hex/EtOAc (1/0.33: 25\%), 0.16

HRMS (ESI): $m / z$ calculated for $\left[\mathrm{C}_{13} \mathrm{H}_{17} \mathrm{FO}_{3} \mathrm{Na}\right]^{+}:$263.1060; [M] ${ }^{+}$found: 263.1056

The ee was determined by HPLC analysis on Chiralpak OD-H column, hexane:IPA = 95/5; flow rate $=1 \mathrm{~mL} / \mathrm{min}$; UV detection at $210 \mathrm{~nm} ; \mathrm{t}_{\mathrm{R}}(R)=11.96 \mathrm{~min}$ (major), $\mathrm{t}_{\mathrm{R}}(S)=12.95 \mathrm{~min}$ (minor), ee: 94\%. HPLC chromatograms are shown below for the racemic standard (top) and enantioenriched product (bottom). 
$r a c-23 b$

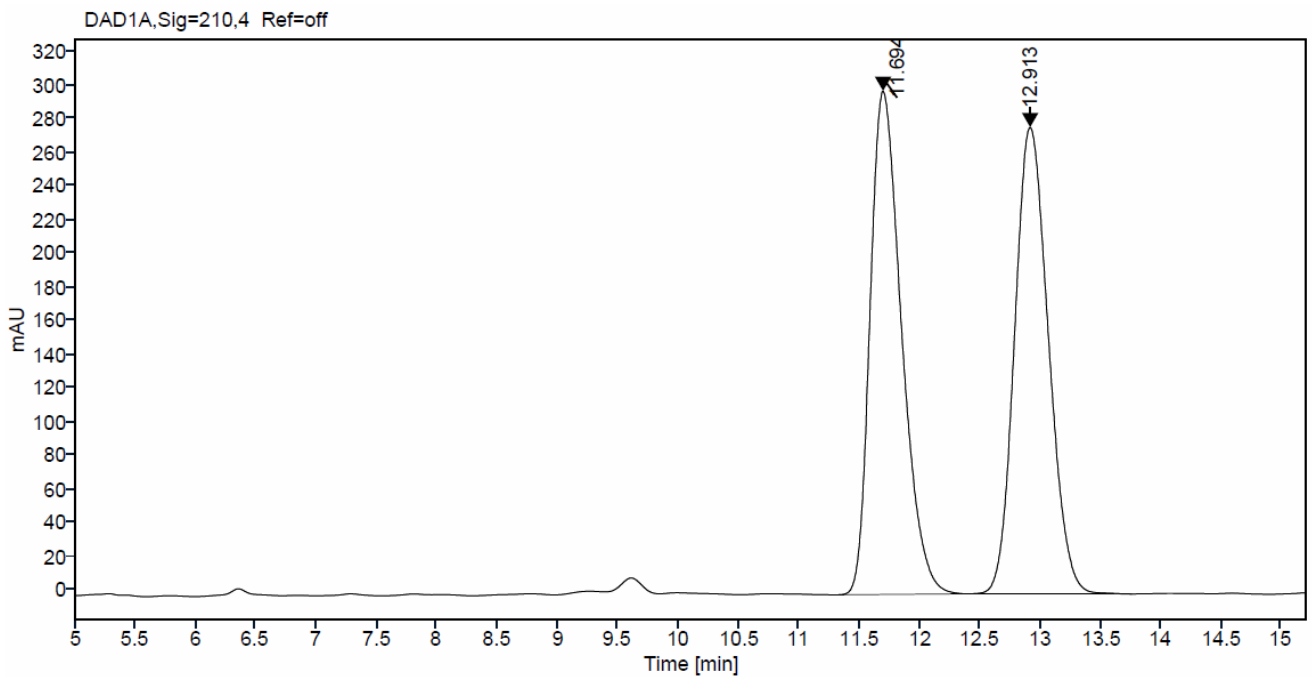

\section{Single Injection Report}

\section{Agilent Technologies}

\begin{tabular}{rrr}
\multicolumn{1}{l}{$\begin{array}{l}\text { Signal: } \\
\text { RT [min] }\end{array}$} & DAD1A,Sig=210,4 Ref=off \\
11.694 & 5399.6504 & Area \\
12.913 & 5399.1612 & 49.99023 \\
Sum & 10798.8116 &
\end{tabular}

$(R)-23 \mathbf{b}$

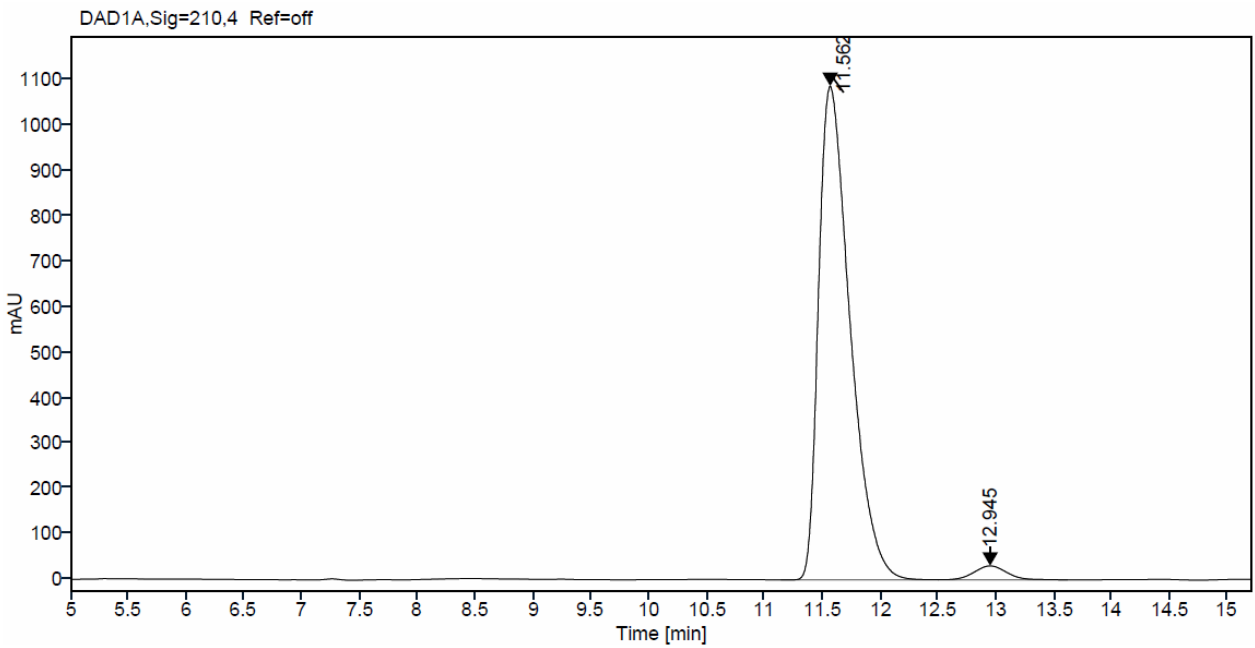

\section{Single Injection Report}

\begin{tabular}{rrr}
\multicolumn{1}{l}{$\begin{array}{c}\text { Signal: } \\
\text { RT [min] }\end{array}$} & DAD1A, Sig $=210,4$ Ref $=$ off \\
11.562 & 20458.3867 & Area\% \\
12.945 & 604.2926 & 2.8690 \\
Sum & 21062.6792 &
\end{tabular}




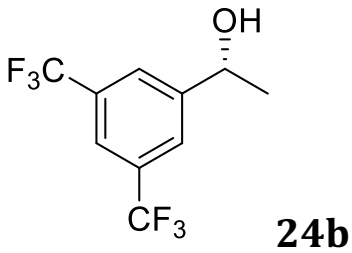

Synthesized using Method A.

${ }^{1} \mathrm{H}$ NMR (500 MHz, $\left.\mathrm{CDCl}_{3}\right) \delta: 7.86(\mathrm{~s}, 2 \mathrm{H}), 7.80(\mathrm{~s}, 1 \mathrm{H}), 5.06(\mathrm{q}, J=6.5 \mathrm{~Hz}, 1 \mathrm{H}), 1.94(\mathrm{~s}, 1 \mathrm{H})$, $1.56(\mathrm{~d}, J=6.5 \mathrm{~Hz}, 3 \mathrm{H})$.

${ }^{13} \mathrm{C}$ NMR (126 MHz, $\left.\mathrm{CDCl}_{3}\right) \delta: 148.2,131.7(\mathrm{q}, J=33.3 \mathrm{~Hz}), 125.7,123.3(\mathrm{q}, J=273.42 \mathrm{~Hz})$, 121.5-121.4 (m), 69.3, 25.6.

Yield: 98\% (0.0252 g)

$\mathrm{R}_{\mathrm{f}}$ : hex/EtOAc (1/0.2: 16\%), 0.30

The ee was determined by HPLC analysis on Chiralpak OD-H column, hexane:IPA = 96/4; flow rate $=0.7 \mathrm{~mL} / \mathrm{min}$; $\mathrm{UV}$ detection at $210 \mathrm{~nm} ; \mathrm{t}_{\mathrm{R}}(S)=7.45 \mathrm{~min}(\operatorname{minor}), \mathrm{t}_{\mathrm{R}}(R)=8.26 \mathrm{~min}$ (major), ee $=93 \%(R)$. HPLC chromatograms are shown below for the racemic standard (top) and enantioenriched product (bottom). 
$r a c-24 b$

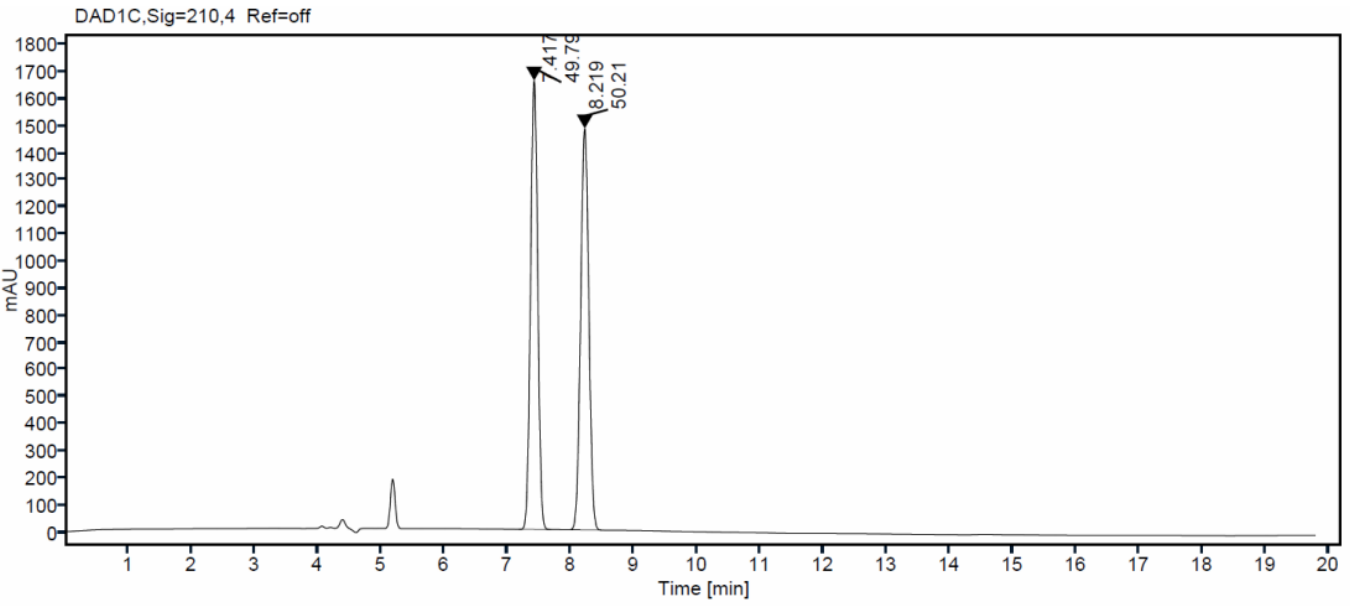

\section{Single Injection Report}

\section{Agilent Technologies}

Signal:

DAD1C, Sig=210,4 Ref=off
RT [min]

$\begin{array}{rrr}7.417 & \text { Area } & \text { Area } \% \\ 8.219 & 13239.9968 & 49.7906 \\ \text { Sum } & 13351.3579 & 50.2094 \\ & 26591.3547 & \end{array}$

(R)-24b

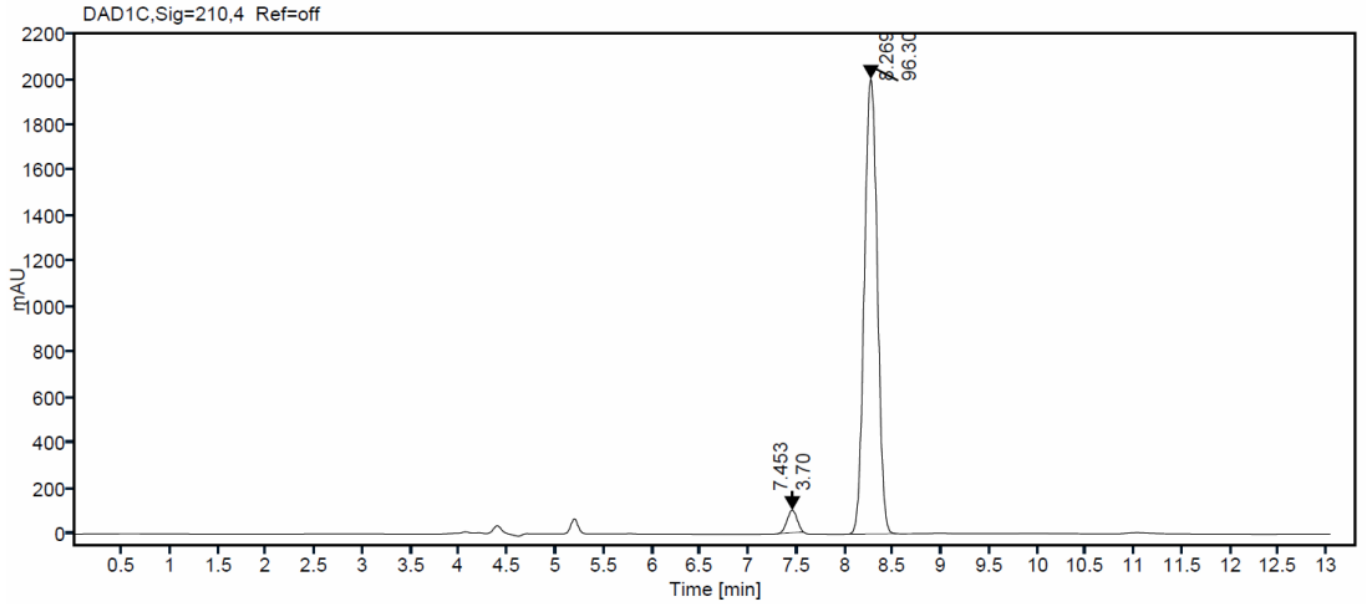

\section{Single Injection Report}

\section{Agilent Technologies}

Signal:

DAD1C, Sig=210,4 Ref=off

RT [min]

7.453

8.269

Sum
Area

722.7554

18795.9385

19518.6939 


\section{References}

1. Lipshutz, B.H.; Ghorai, S.; Abela, A.R.; Moser, R.; Nishikata, T.; Duplais, C.; Krasovskiy, A.; Gaston, R.D.; Gadwood, R.C. TPGS-750-M: A Second-Generation Amphiphile for Metal-Catalyzed Cross-Couplings in Water at Room Temperature.J. Org. Chem. 2011, $76,4379$.

2. Cortes-Clerget, M., Spink, S. E., Gallagher, G. P., Chaisemartin, L., Filaire, E., Berthon, JY., and Lipshutz, B. H. MC-1. A "designer" surfactant engineered for peptide synthesis in water at room temperature. Green Chem. 2019, 21, 2610.

3. Lipshutz, B.H., Petersen, T.B. and Abela, A.R. Room-temperature Suzuki-Miyaura couplings in water facilitated by nonionic amphiphiles. Org. Lett. 2008, 10, 1333.

4. Cortes-Clerget, M.; Akporji, N.; Zhou, J.; Gao, F.; Guo, P.; Parmentier, M.; Gallou, F.; Berthon, J-Y.; Lipshutz, B. H. Bridging the gap between transition metal- and biocatalysis via aqueous micellar catalysis. Nat. Comm. 2019, 10, 2169.

5. Lipshutz, B.H. and Taft, B.R. Heck Couplings at Room Temperature in Nanometer Aqueous Micelles. Org. Lett. 2008, 10, 1329.

6. Domski, G.J., Eagan, J.M., De Rosa, C., Di Girolamo, R., LaPointe, A.M., Lobkovsky, E.B., Talarico, G. and Coates, G.W.. Combined experimental and theoretical approach for living and isoselective propylene polymerization." ACS Catalysis 2017, 7, 6930.

7. Buitrago, E., Lundberg, H., Andersson, H., Ryberg, P. and Adolfsson, H. High throughput screening of a catalyst library for the asymmetric transfer hydrogenation of heteroaromatic ketones: formal syntheses of $(R)$-fluoxetine and $(S)$-duloxetine. ChemCatChem 2012, 4, 2082.

8. Siddaraju, Y.; Prabhu, K.R. Iodine promoted $\alpha$-hydroxylation of ketones. Org. Biomol. Chem. 2015, 13, 6749.

9. Hua, Y.Y., Bin, H.Y., Wei, T., Cheng, H.A., Lin, Z.P., Fu, X.F., Li, Y.Q., Xie, J.H., Yan, P.C. and Zhou, Q.L. "Iridium-Catalyzed Asymmetric Hydrogenation of $\gamma$-and $\delta$-Ketoacids for Enantioselective Synthesis of $\gamma$-and $\delta$-Lactones." Org. Lett. 2020, 22, 818. 


\section{7. ${ }^{1} \mathrm{H}$ and ${ }^{13} \mathrm{C}$ NMR spectra}

1b
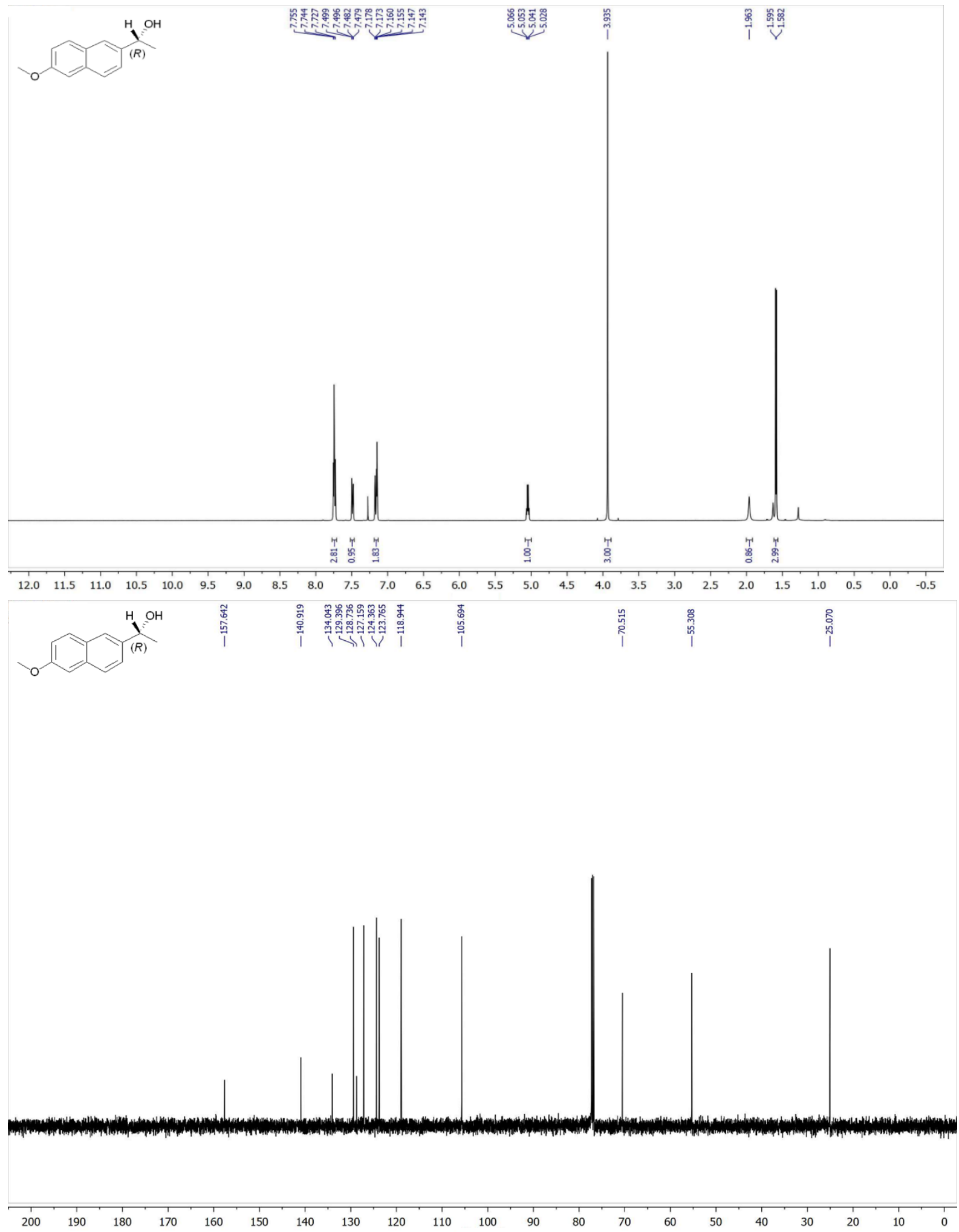
$2 b$
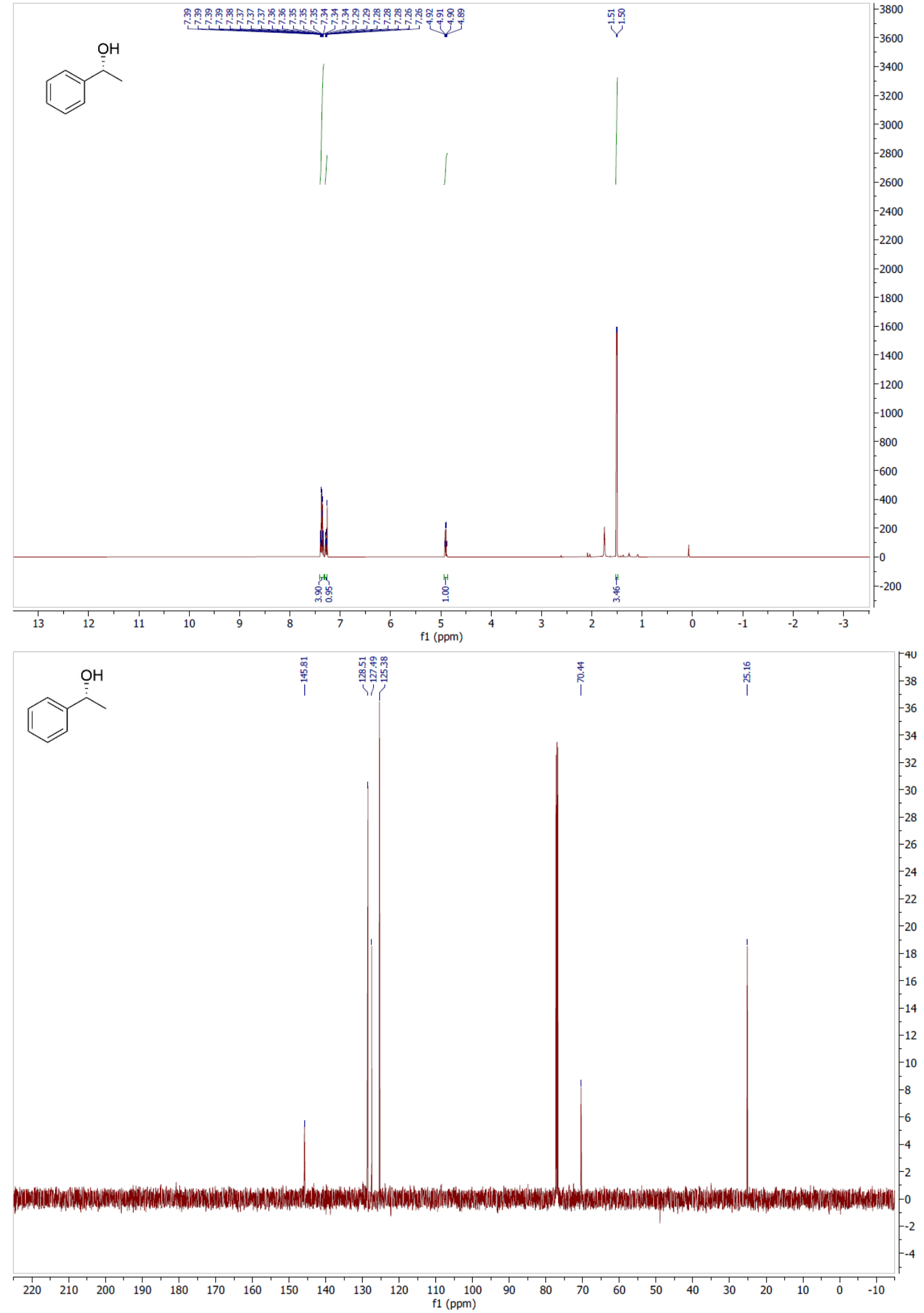
$3 b$

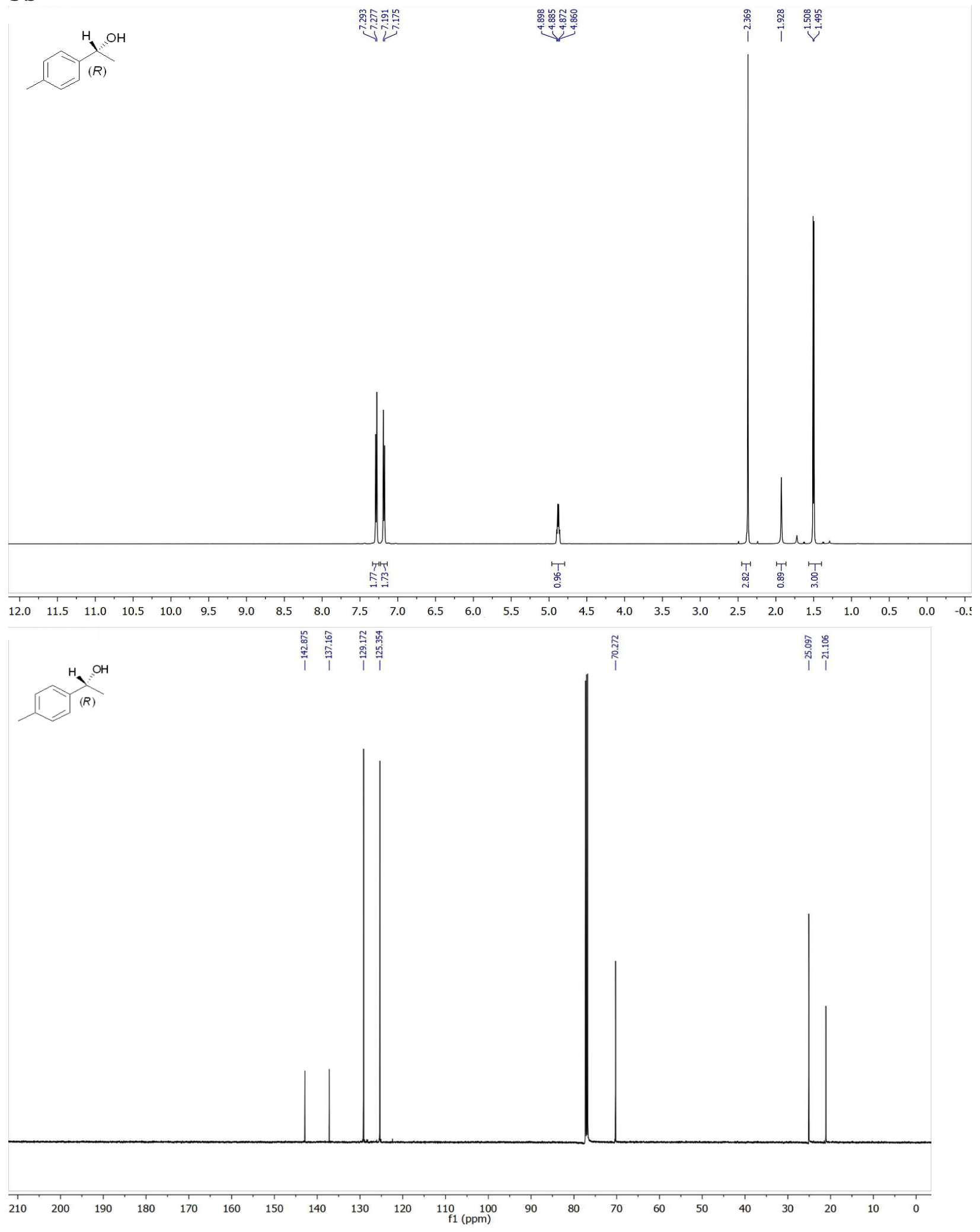


$4 b$

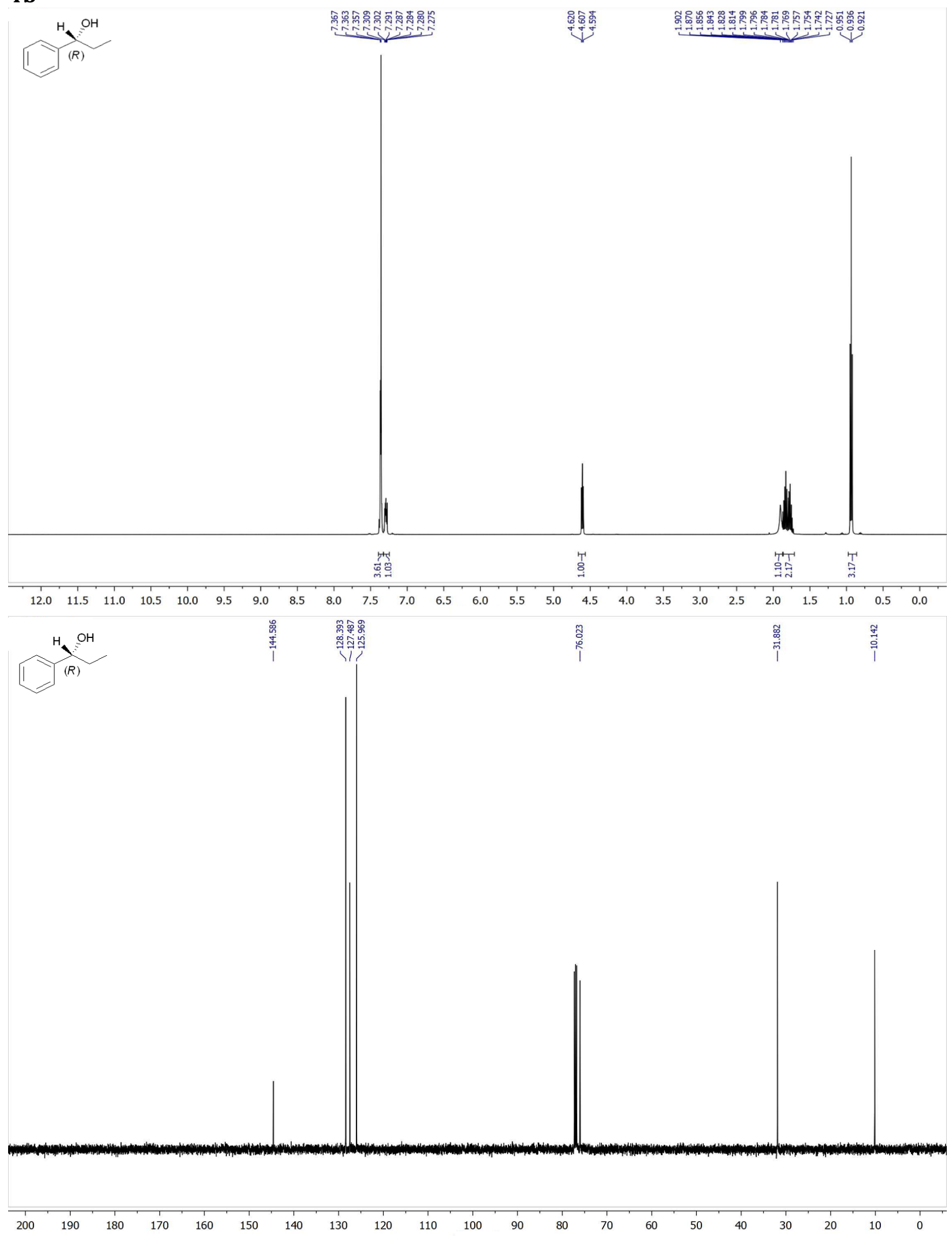




\section{$5 b$}

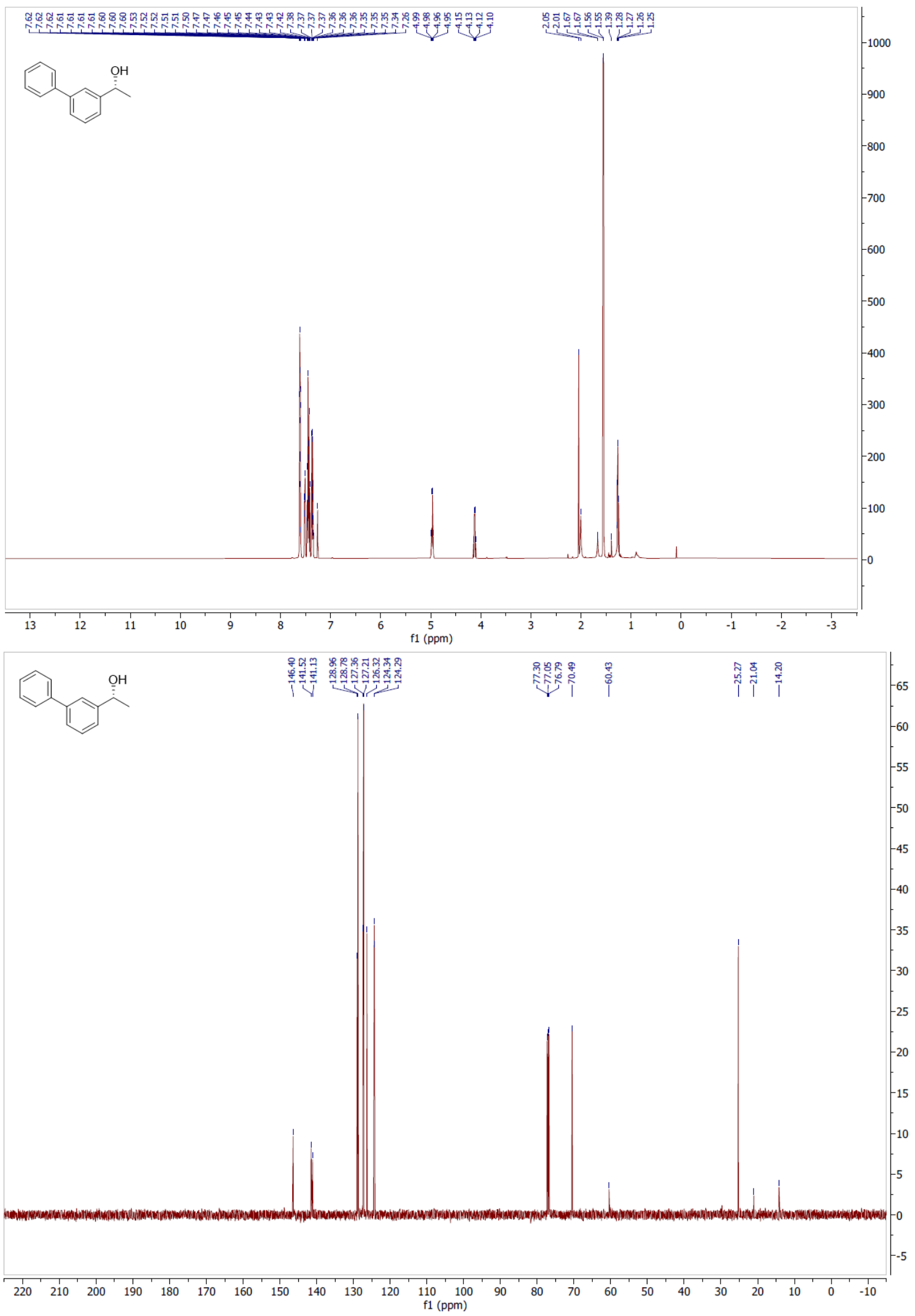


6b

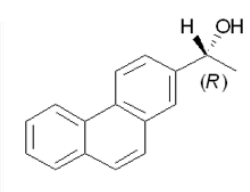

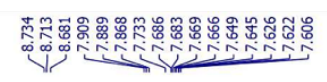

ำ

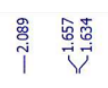
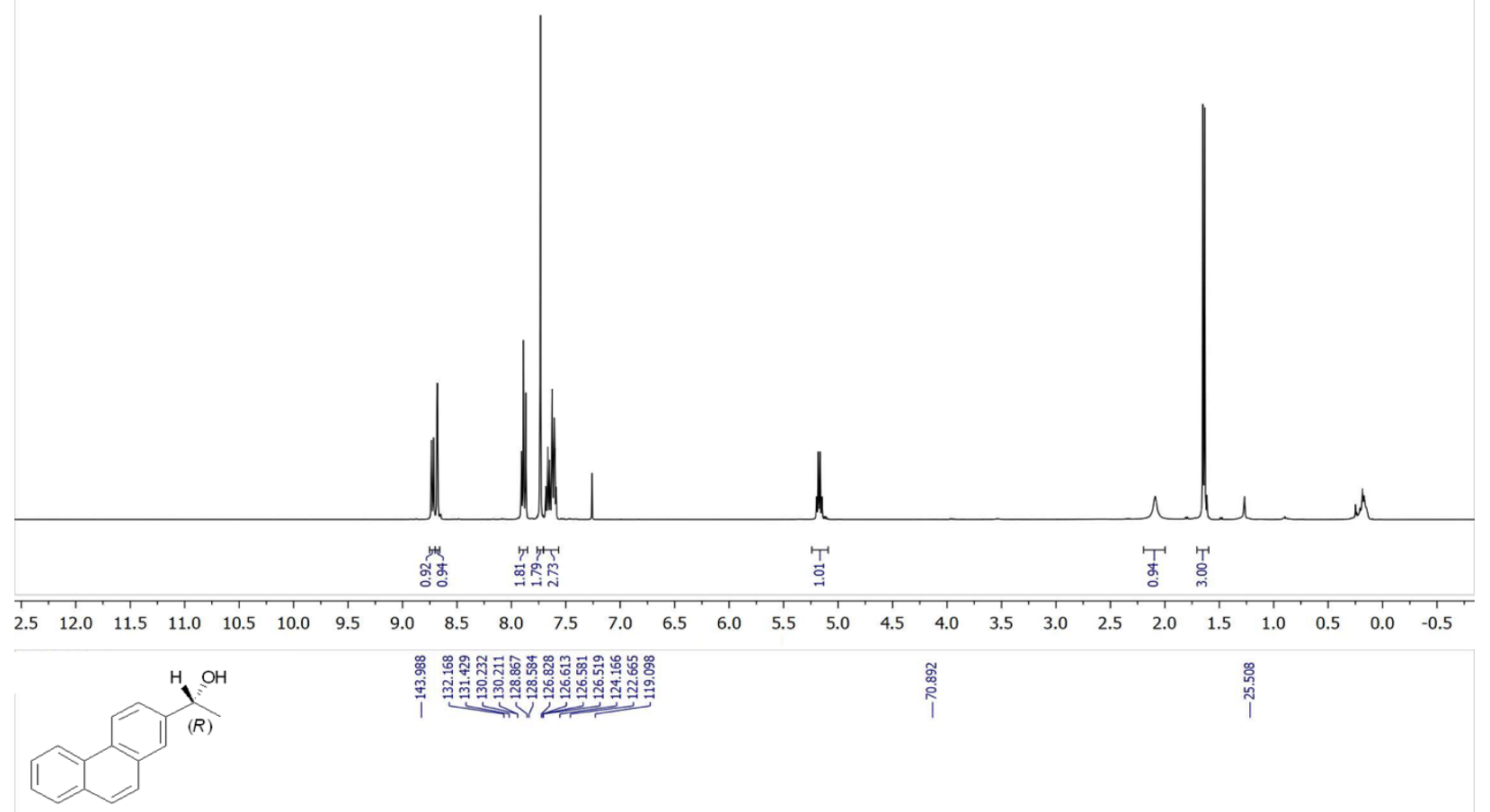

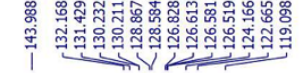
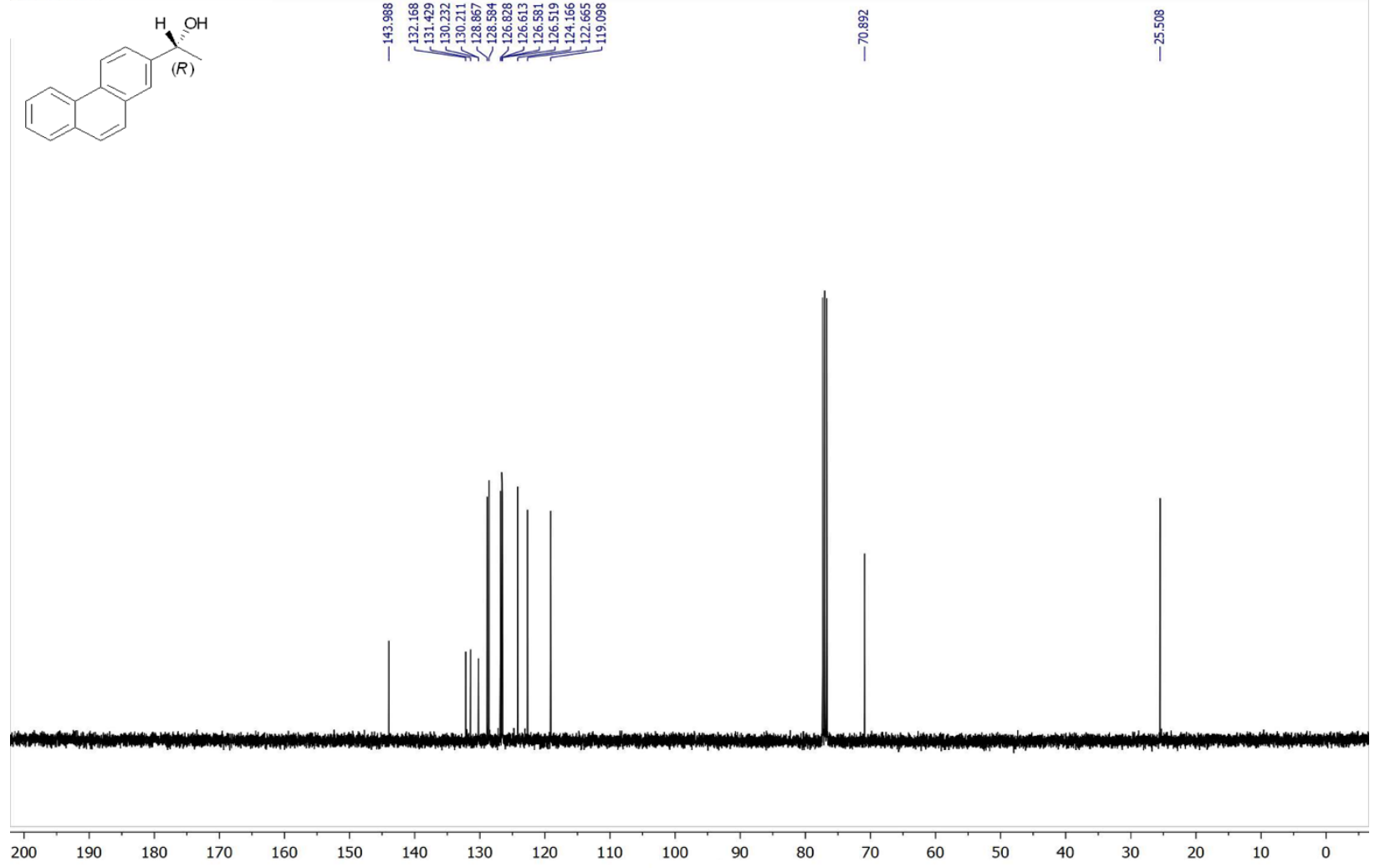

97 
7b
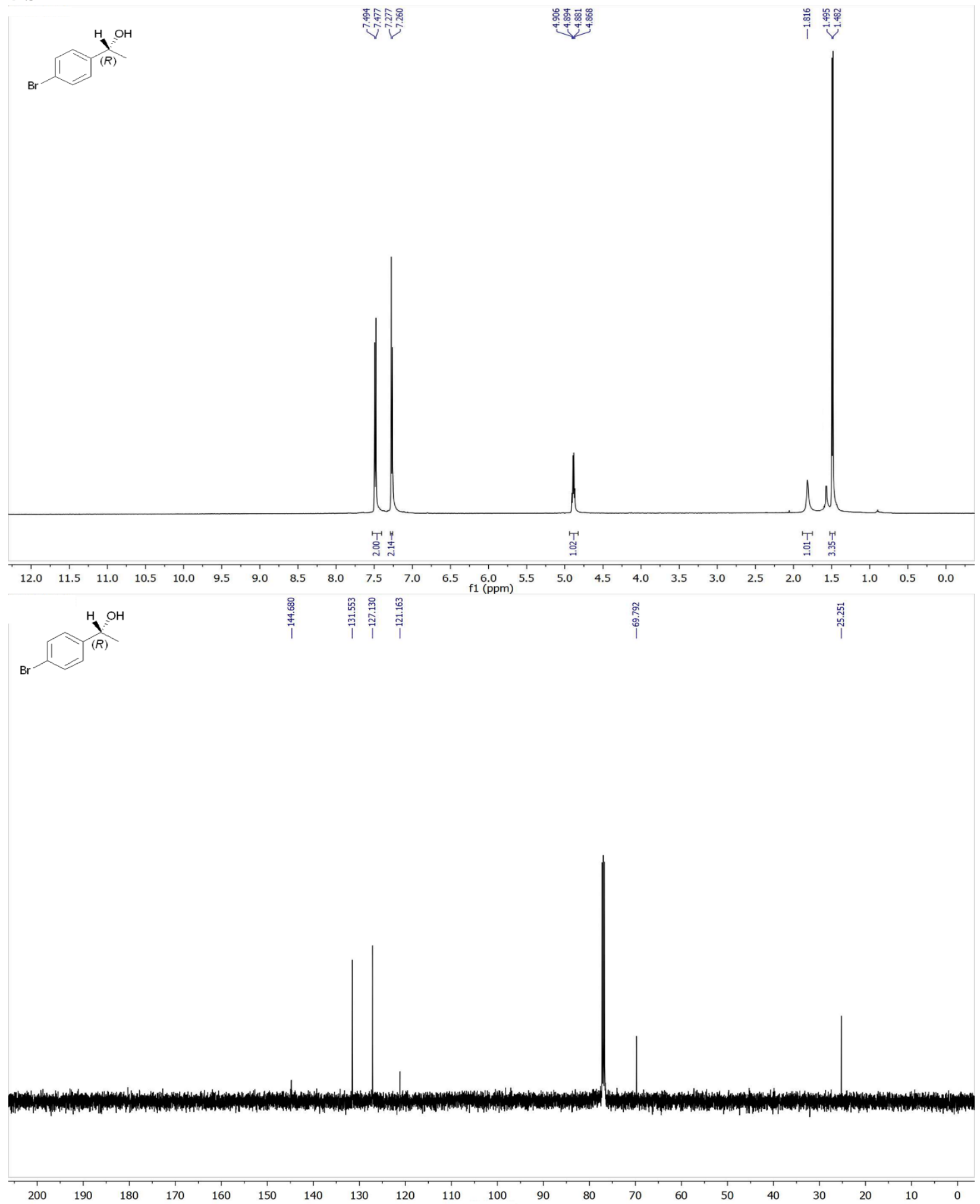
8b

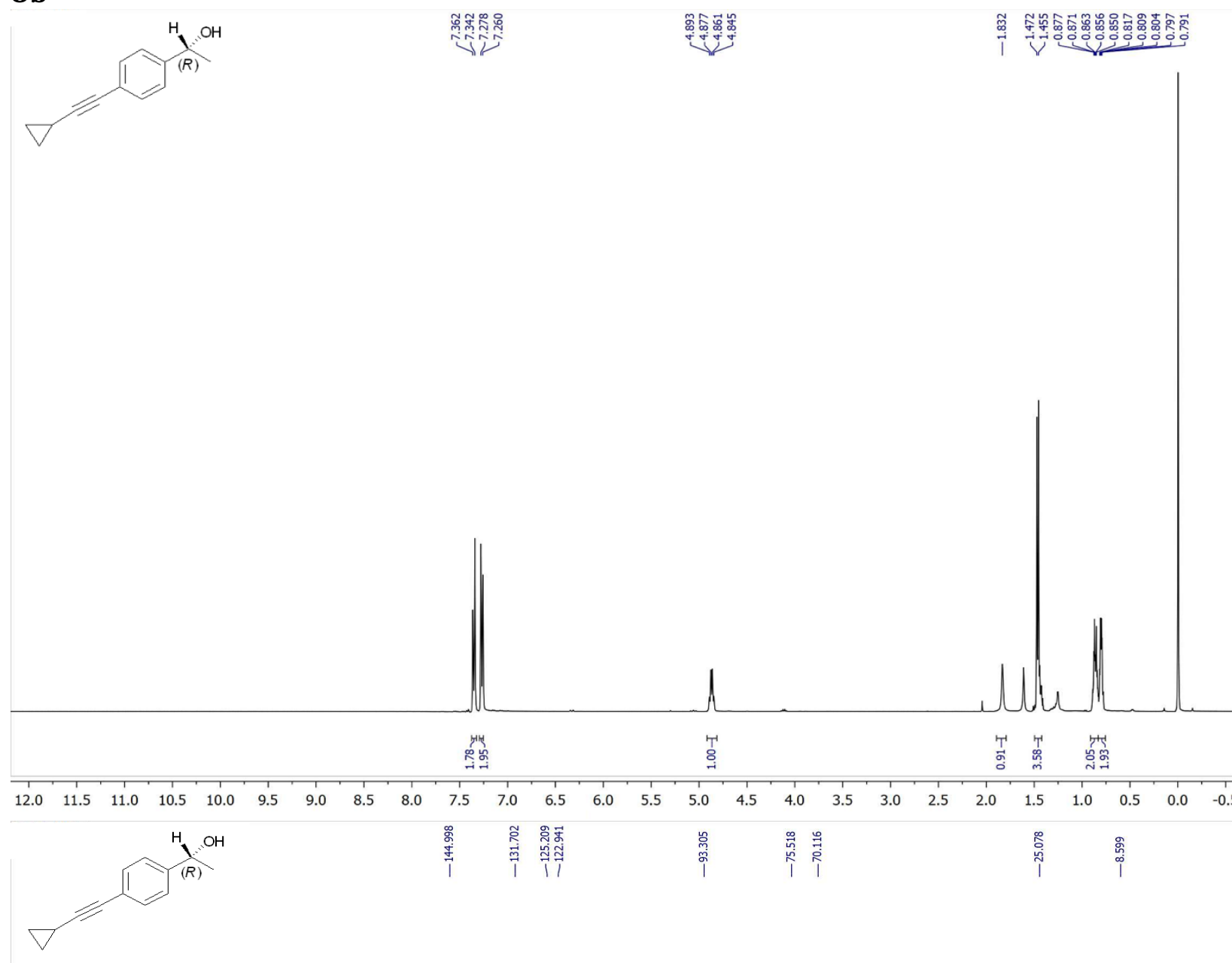

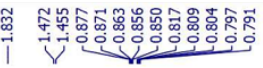


$9 \mathbf{b}$

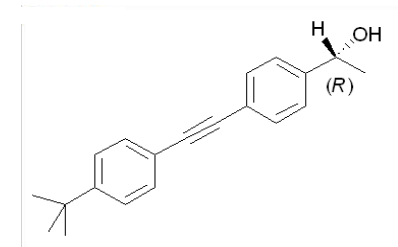

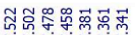

这然证

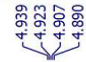

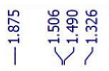
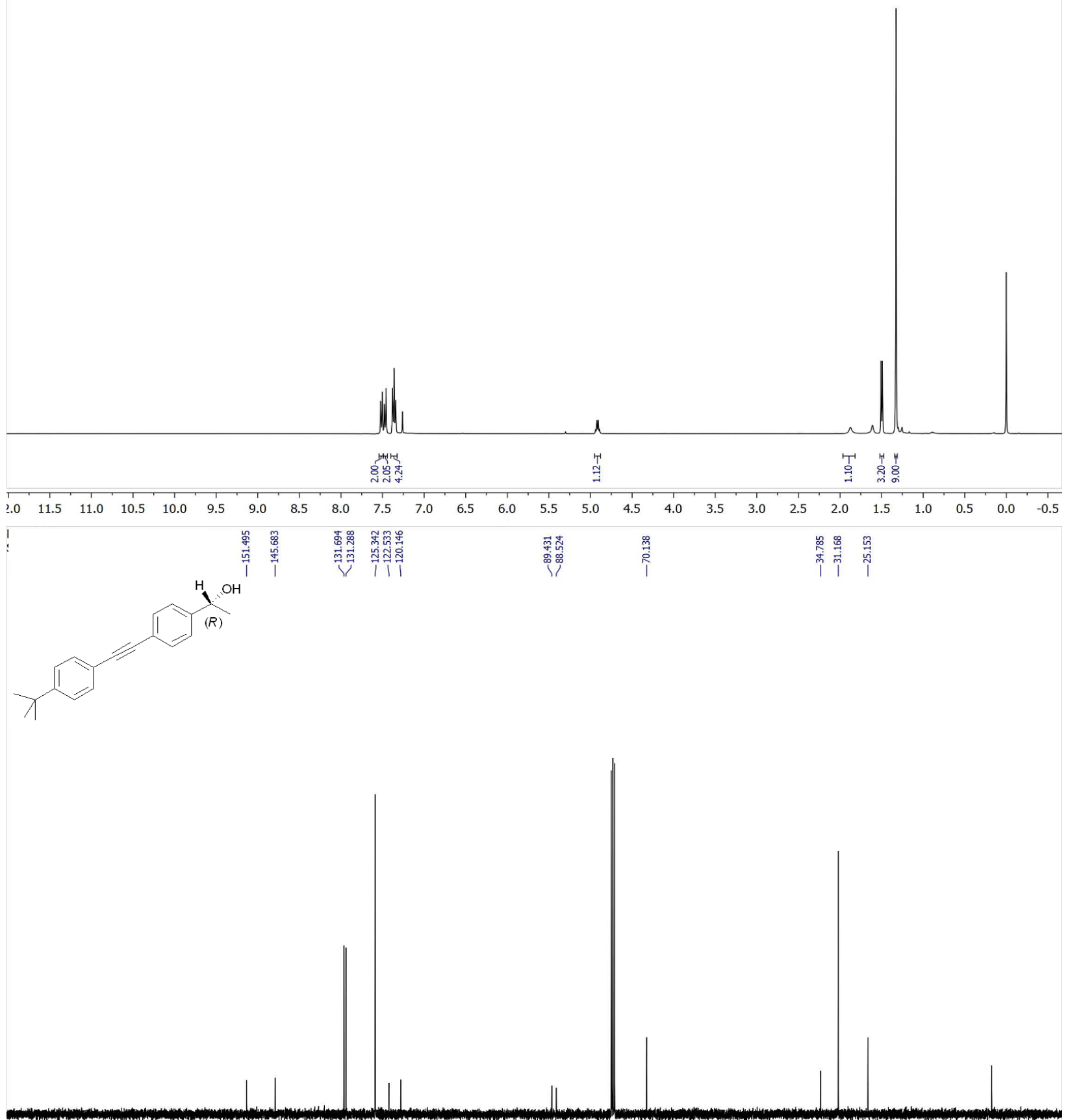

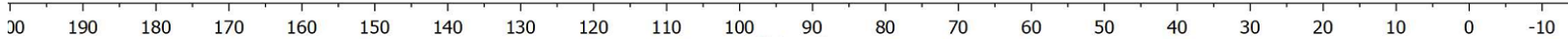


$10 b$
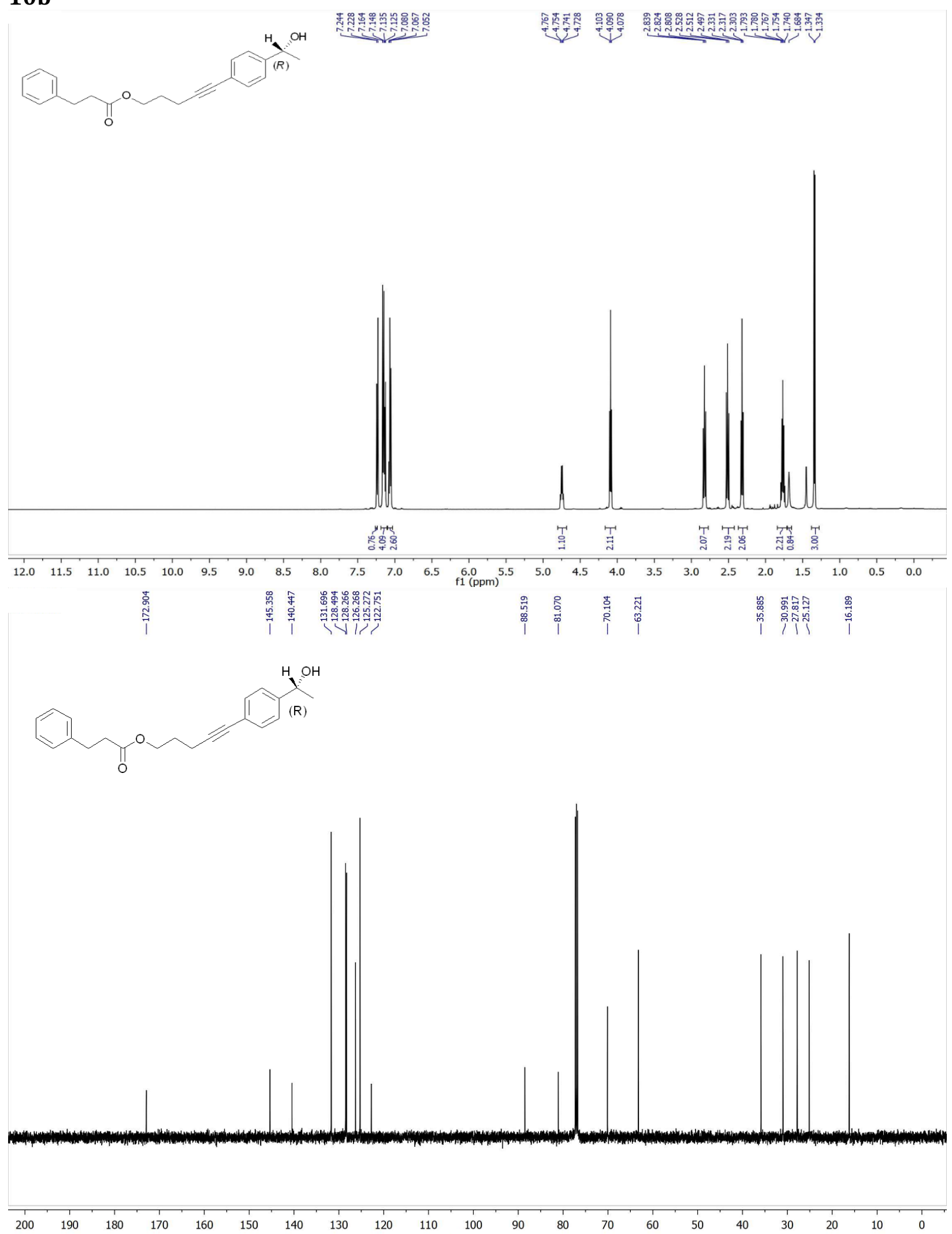


\section{1b}
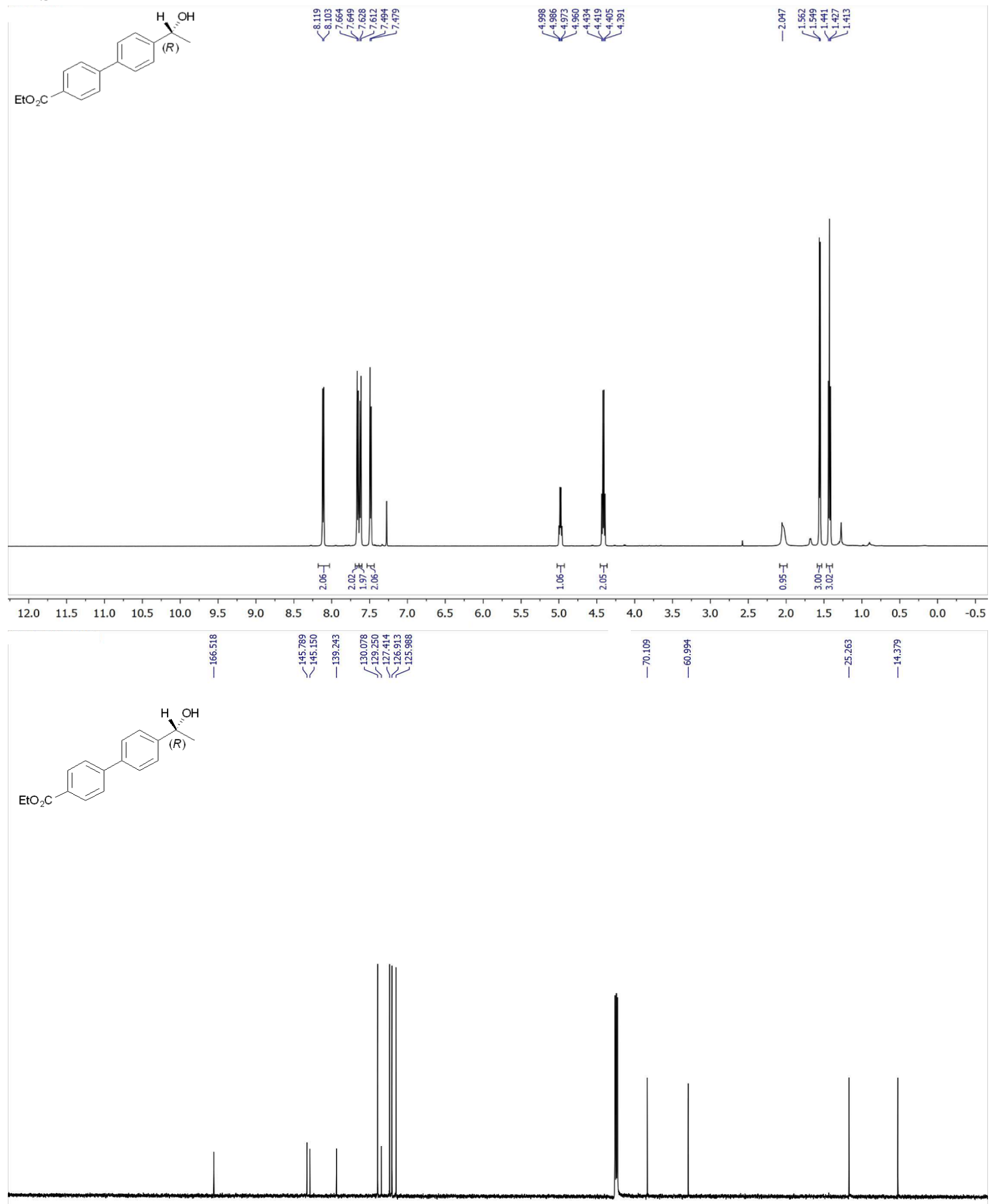

$$
210
$$


12b
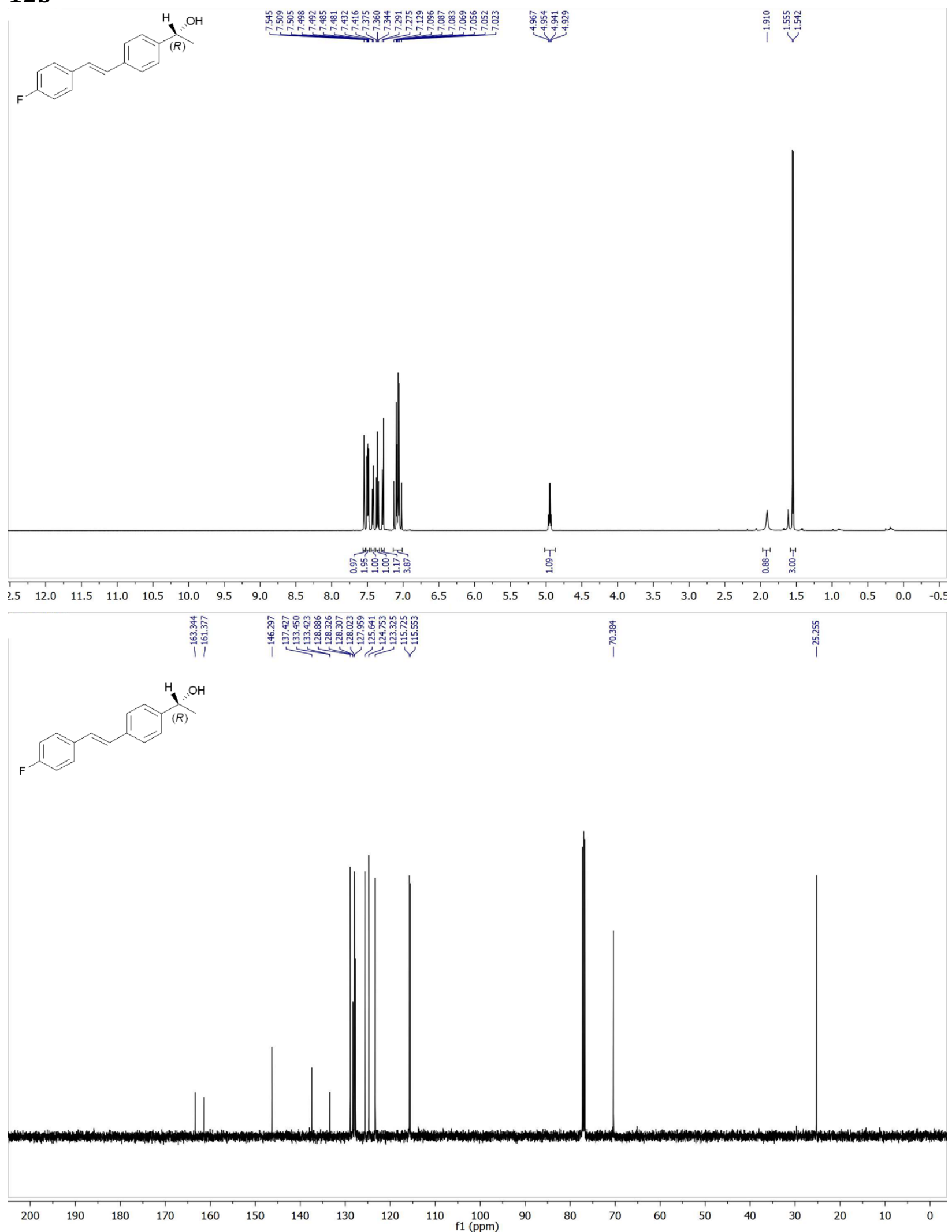


\section{3b}

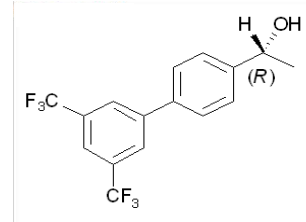

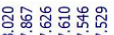

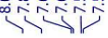

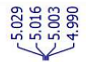

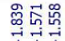

$+7$
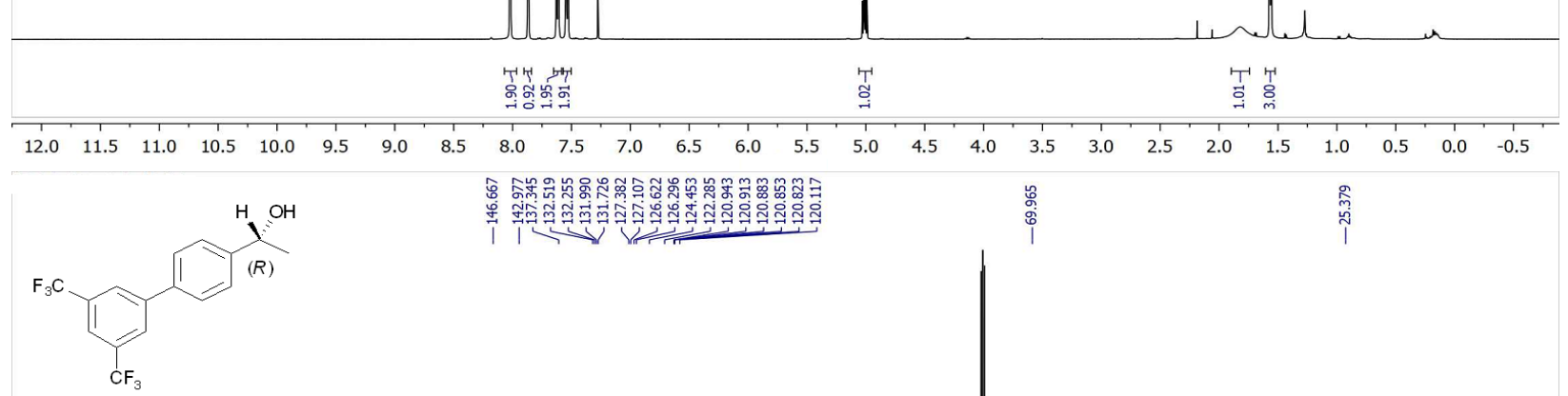

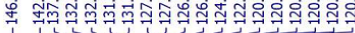

$\stackrel{6}{0}$
$\vdots$
$i$

$\stackrel{\substack{0 \\ i}}{i}$

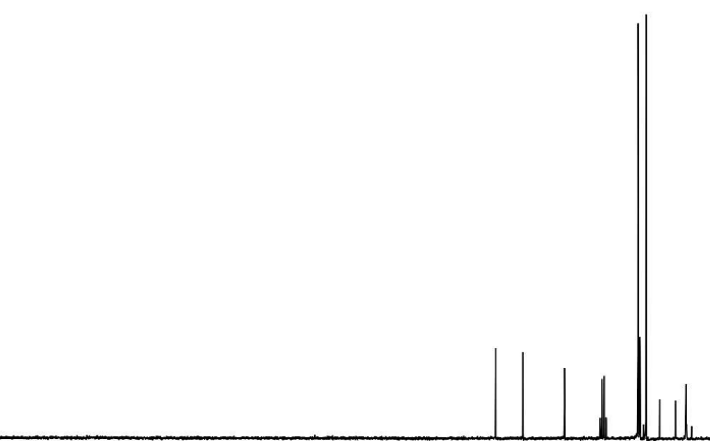

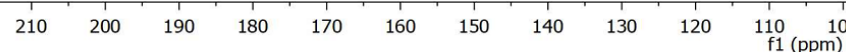


14b
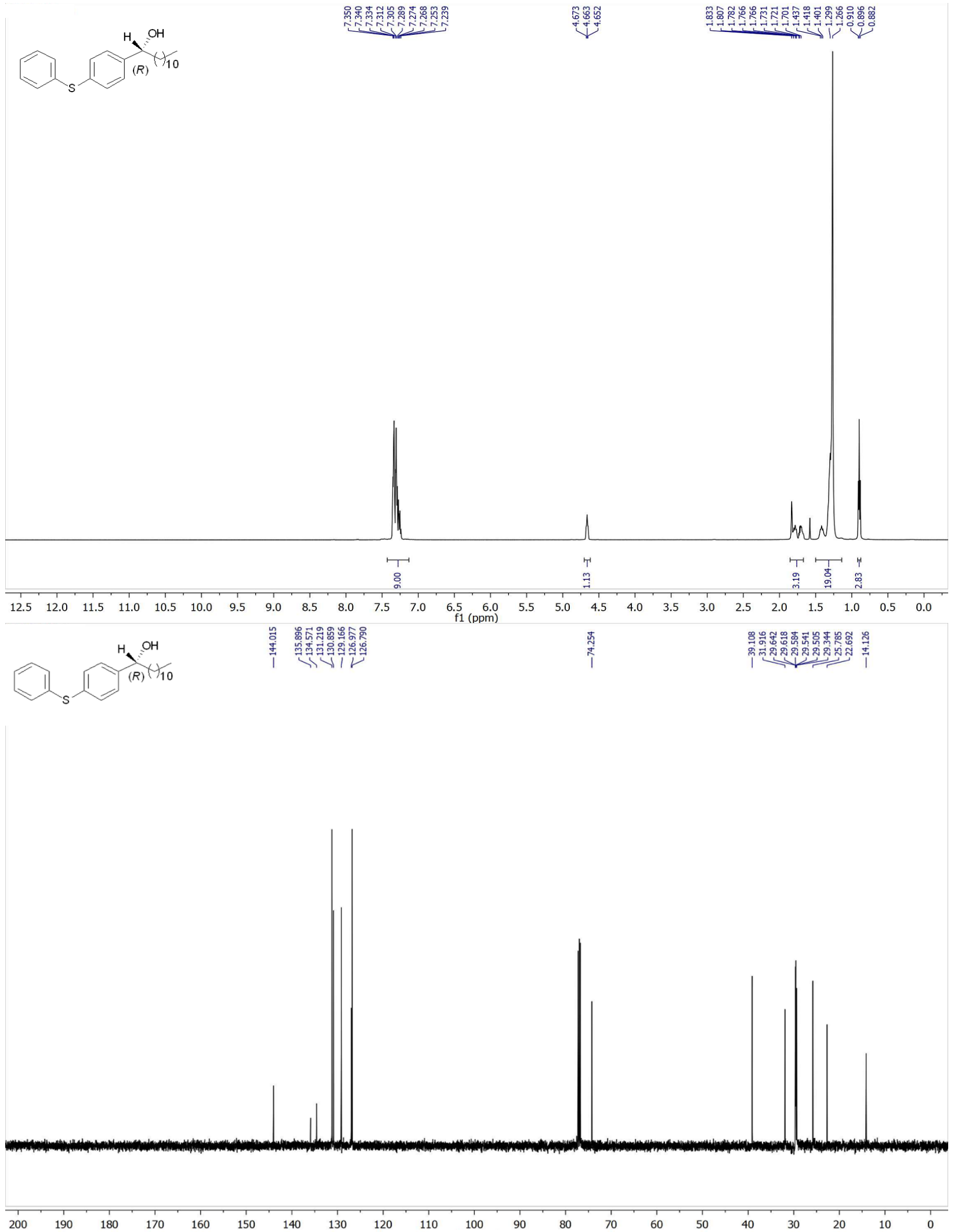


\section{5b}
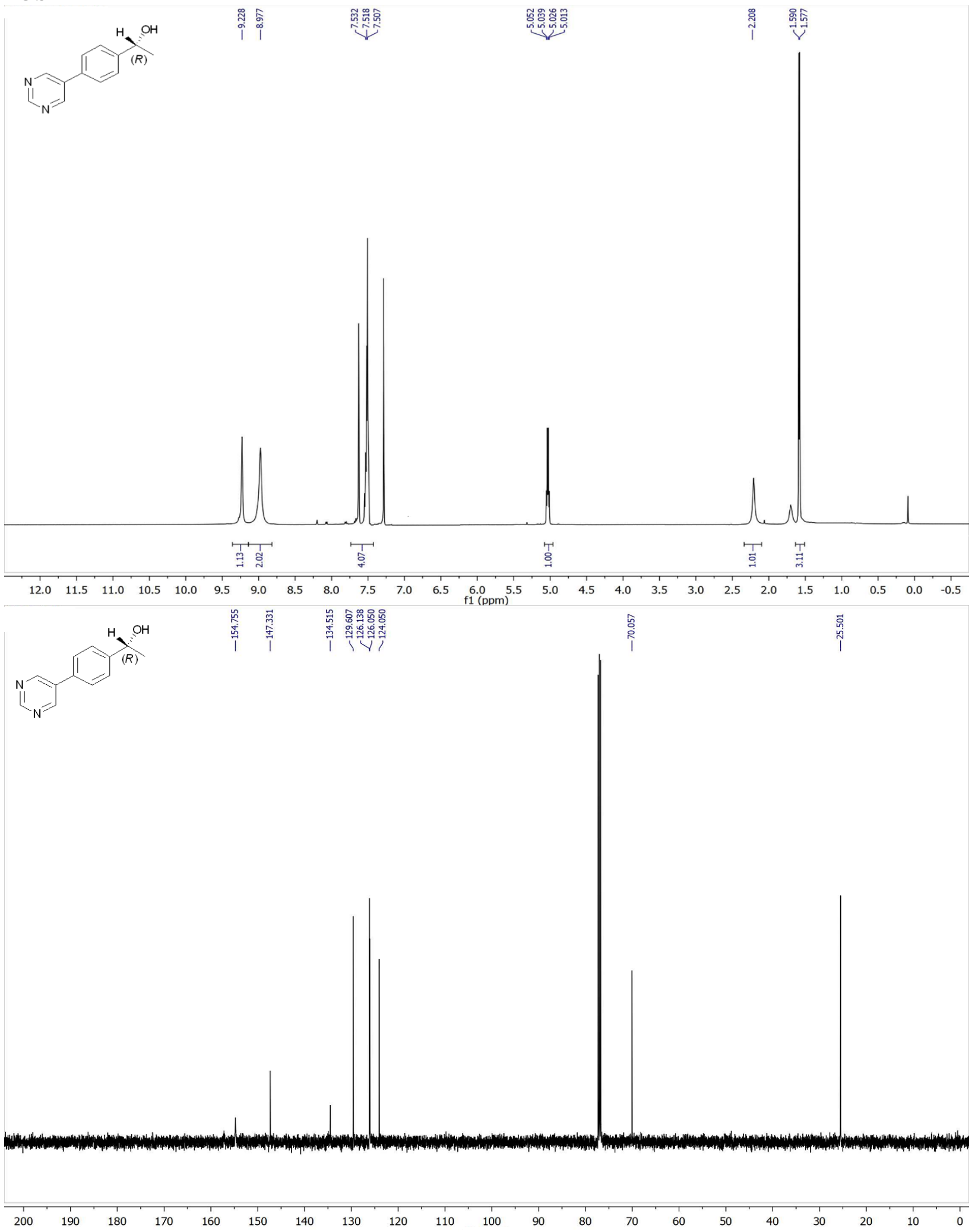


\section{$16 b$}

$\overbrace{\mathrm{Br}}^{\mathrm{N}}(R)$

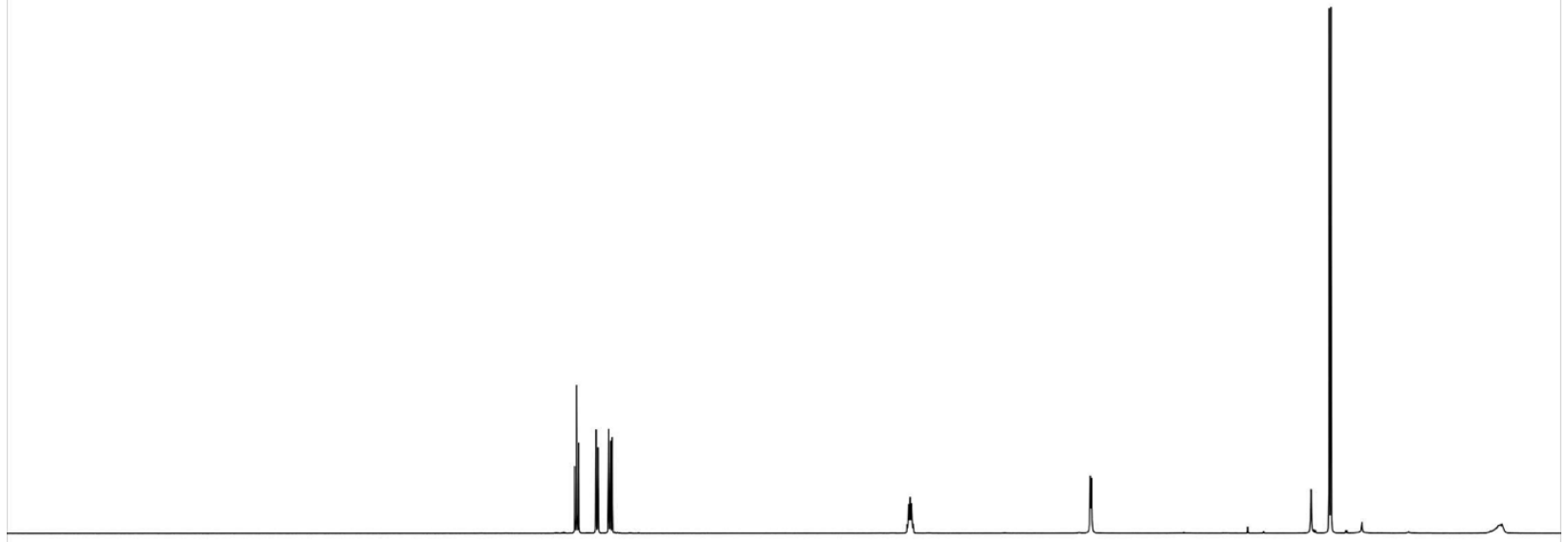

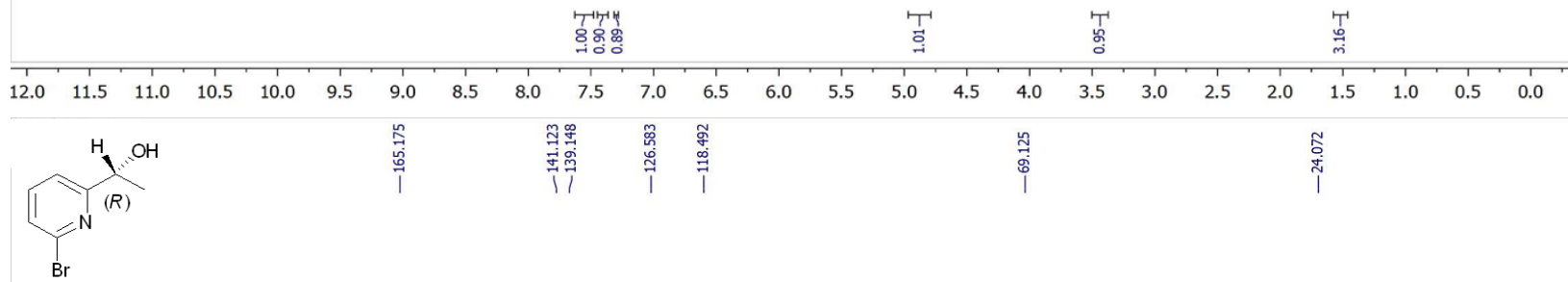
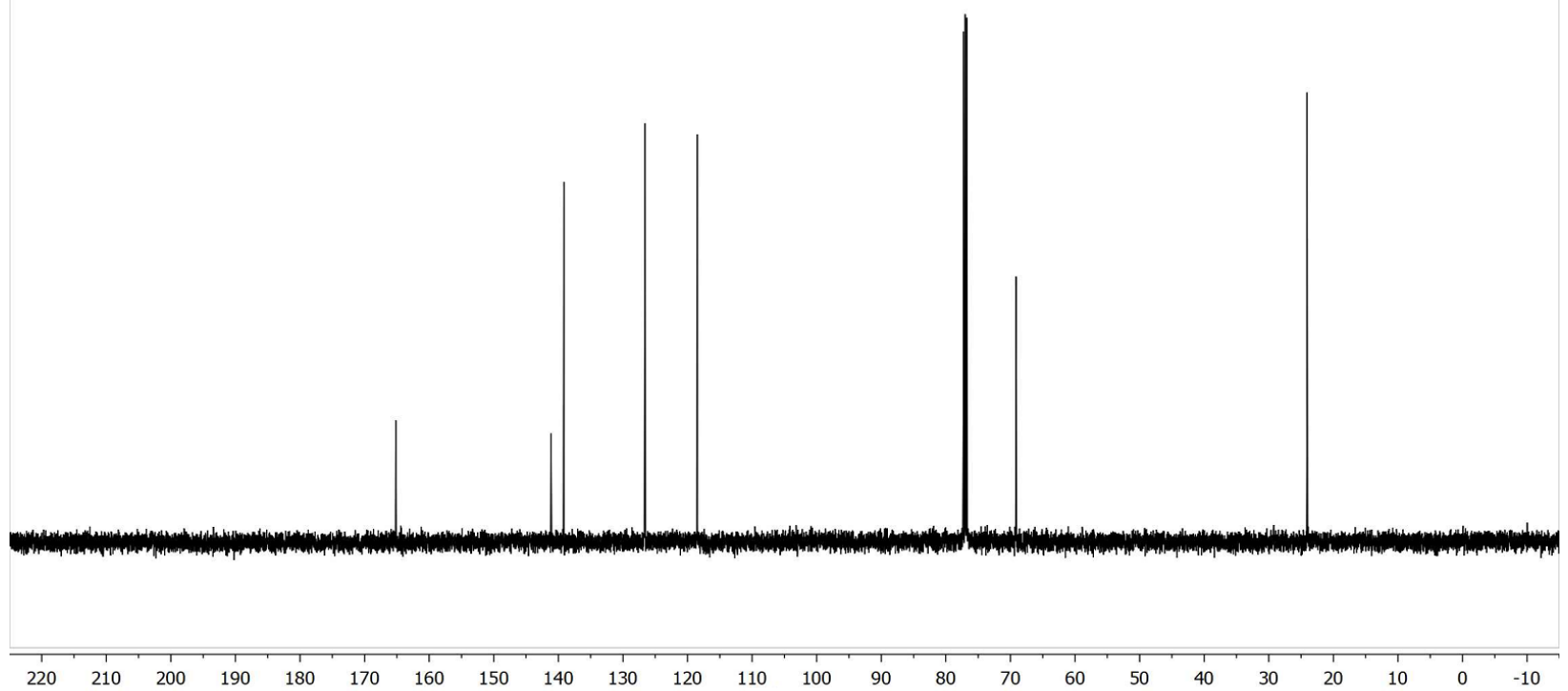


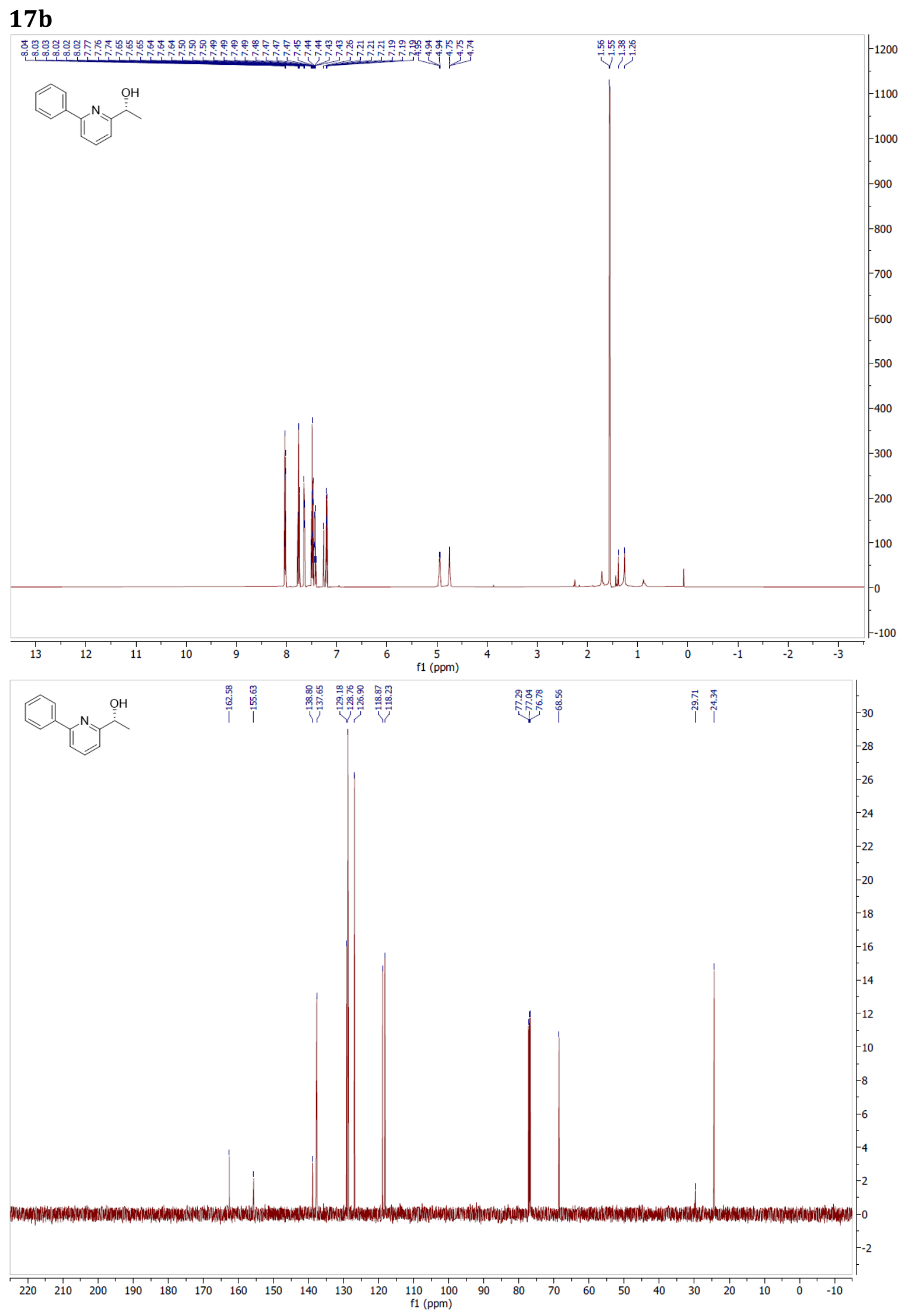

108 
$18 b$
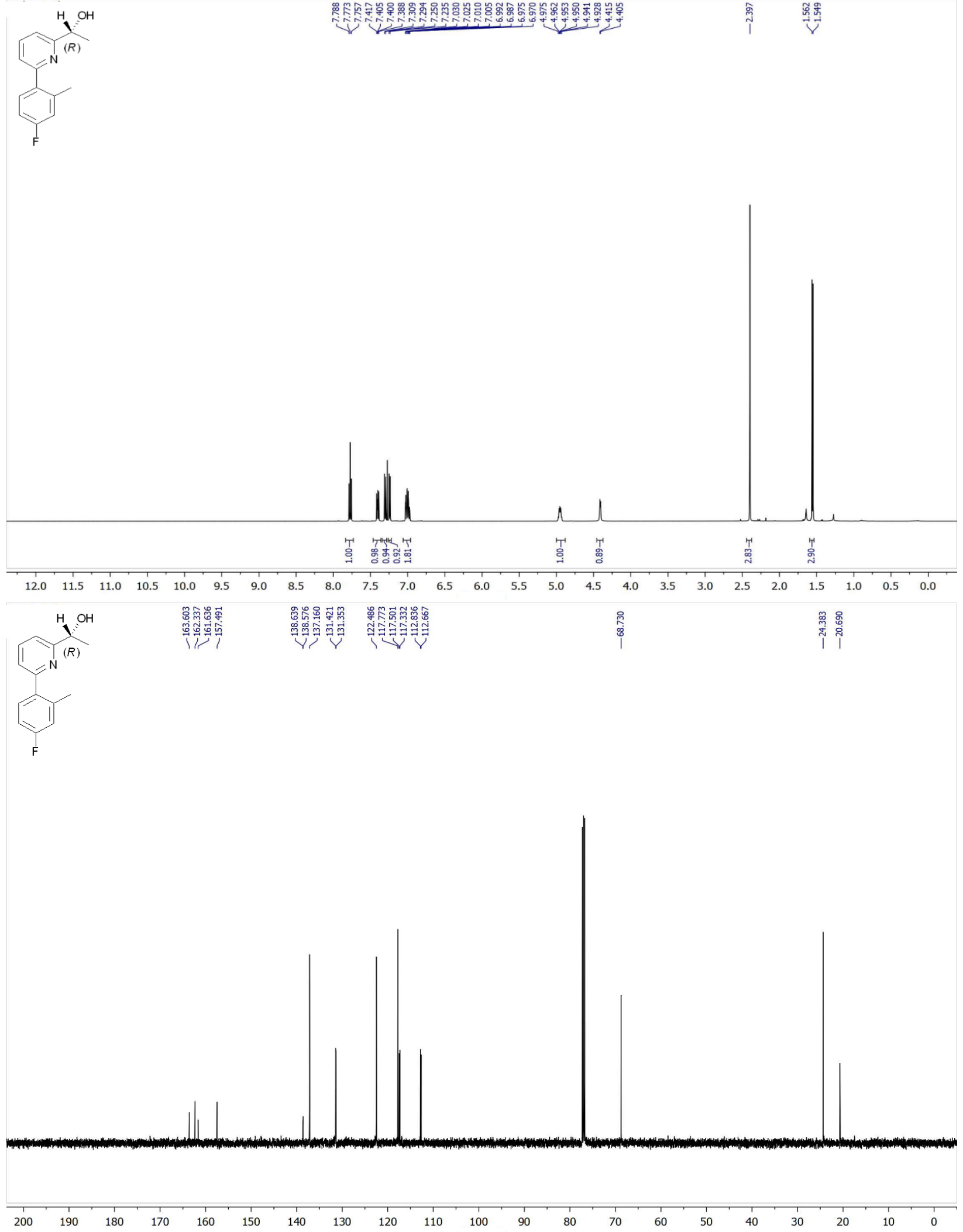


\section{9b}
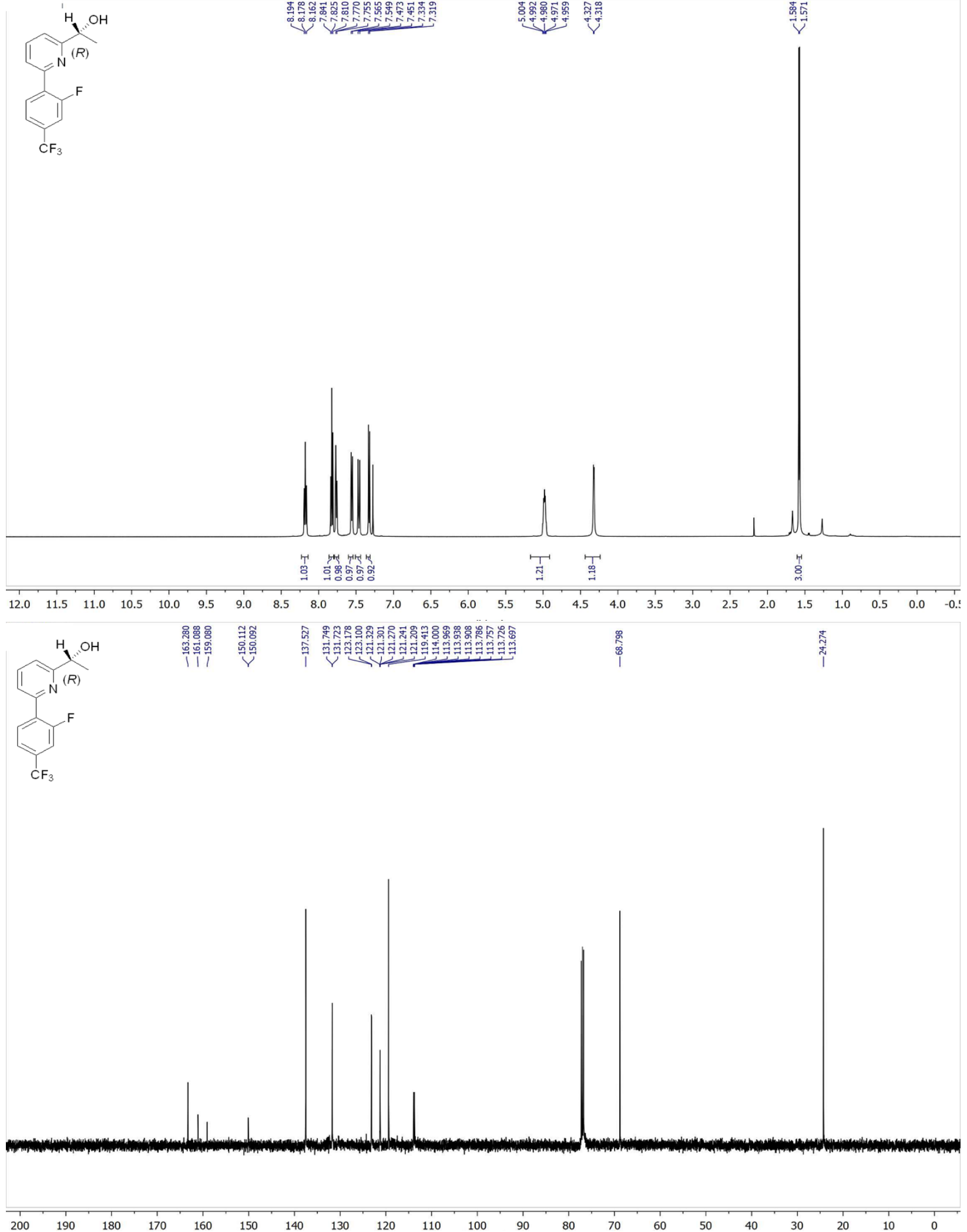
20b

(R)

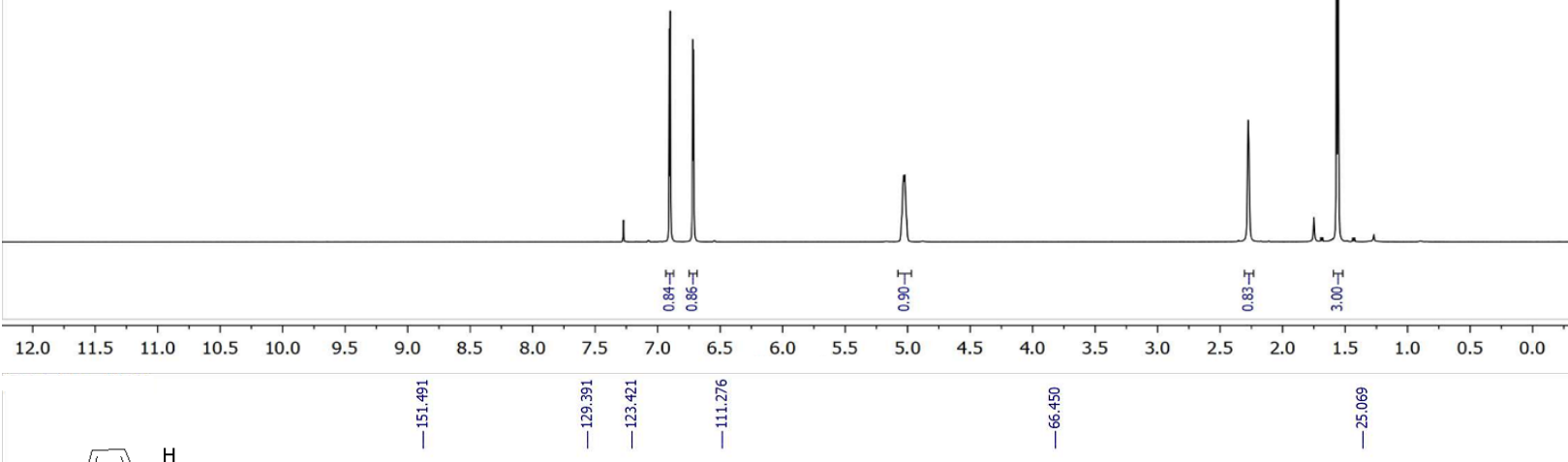

$\mathrm{Br} \int_{S} \int_{(R)}^{H}$
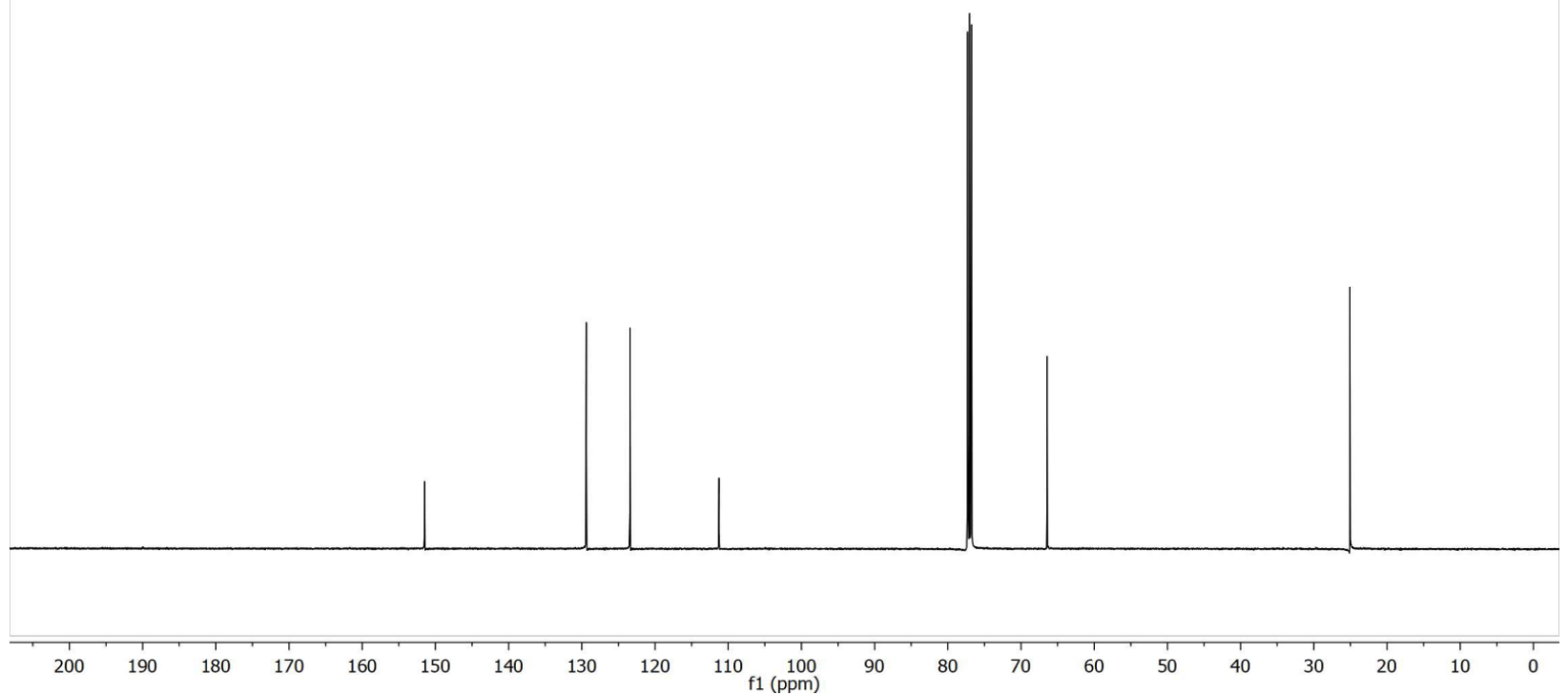
21b
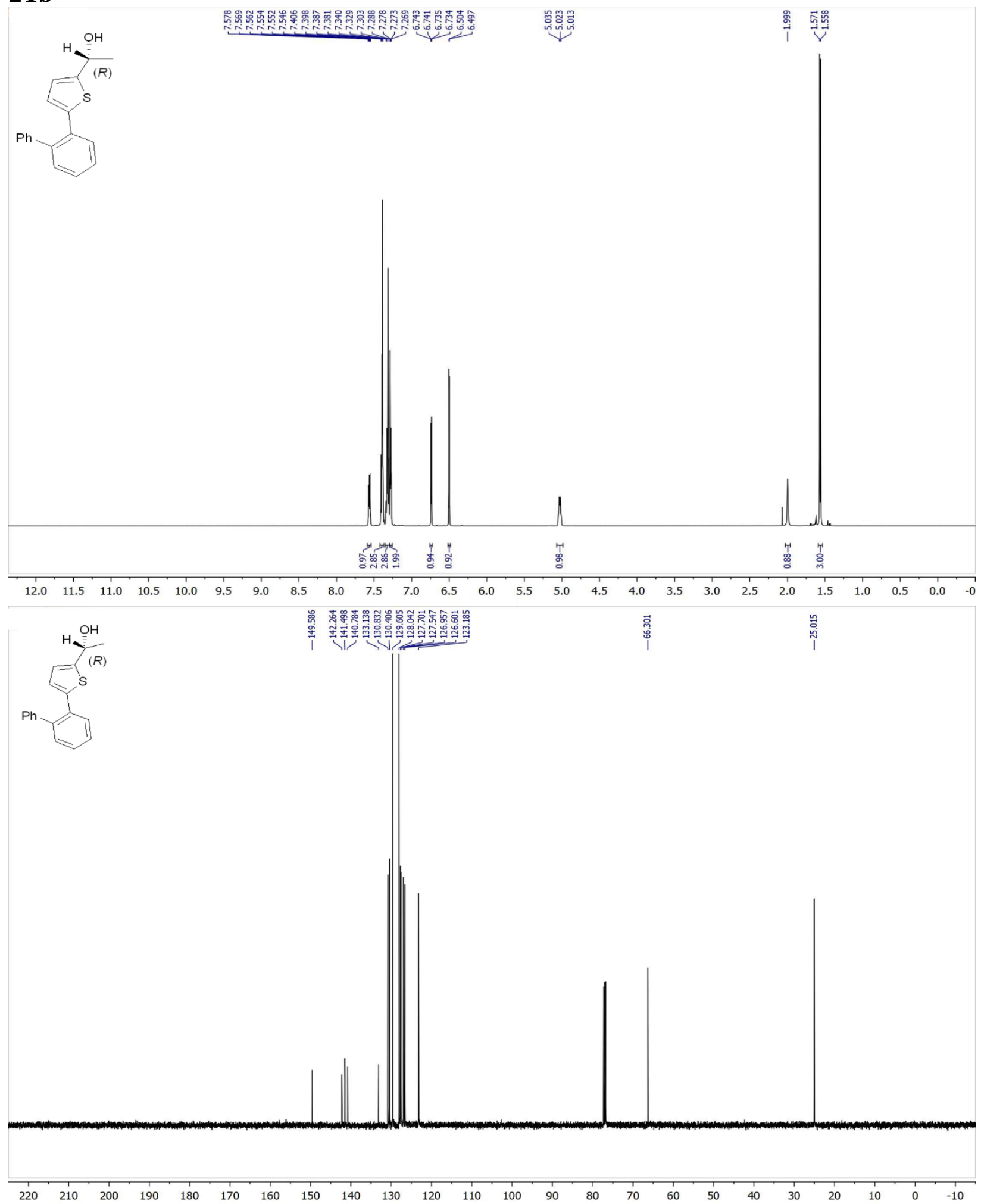


\section{2b}
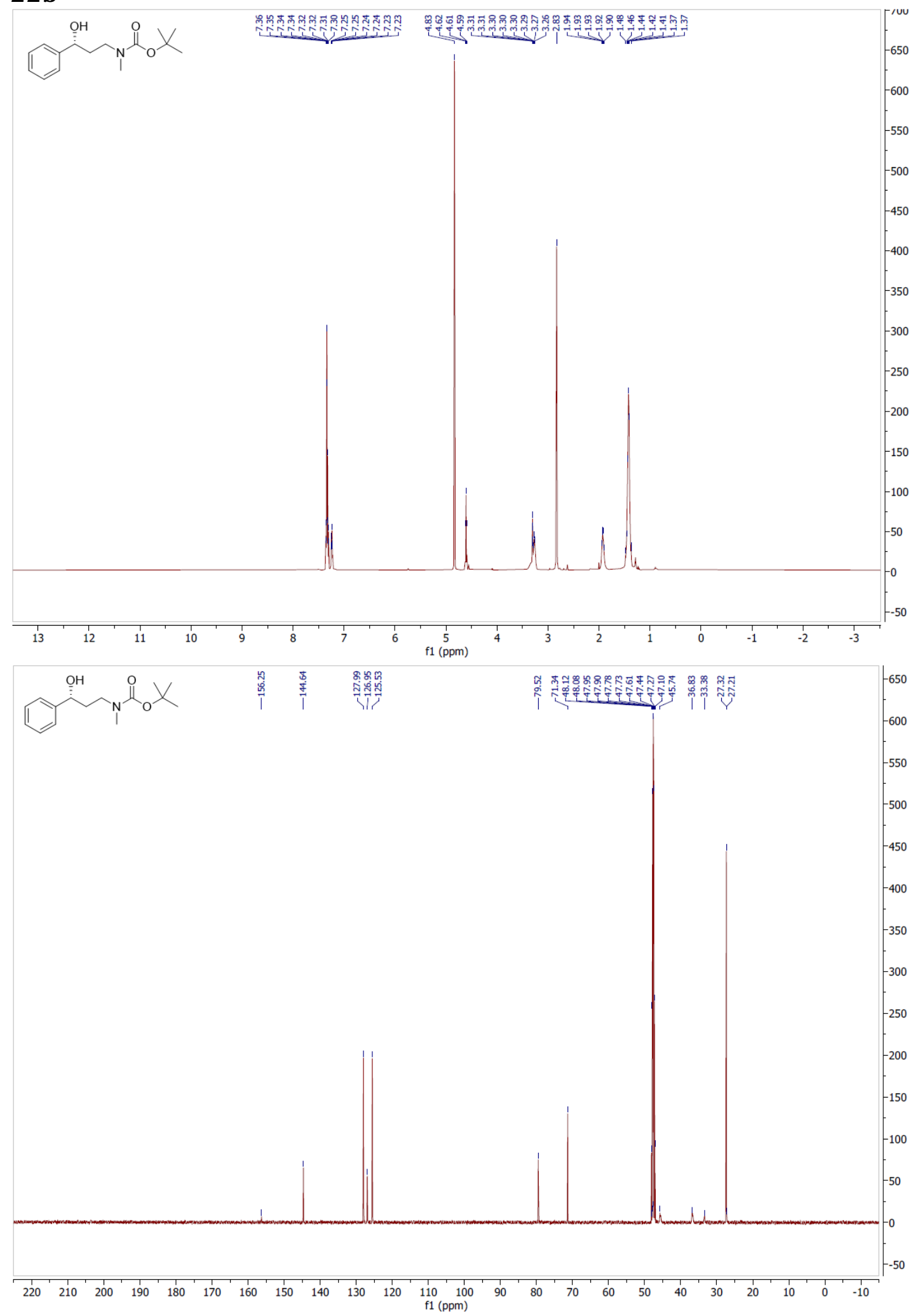


\section{$23 b$}
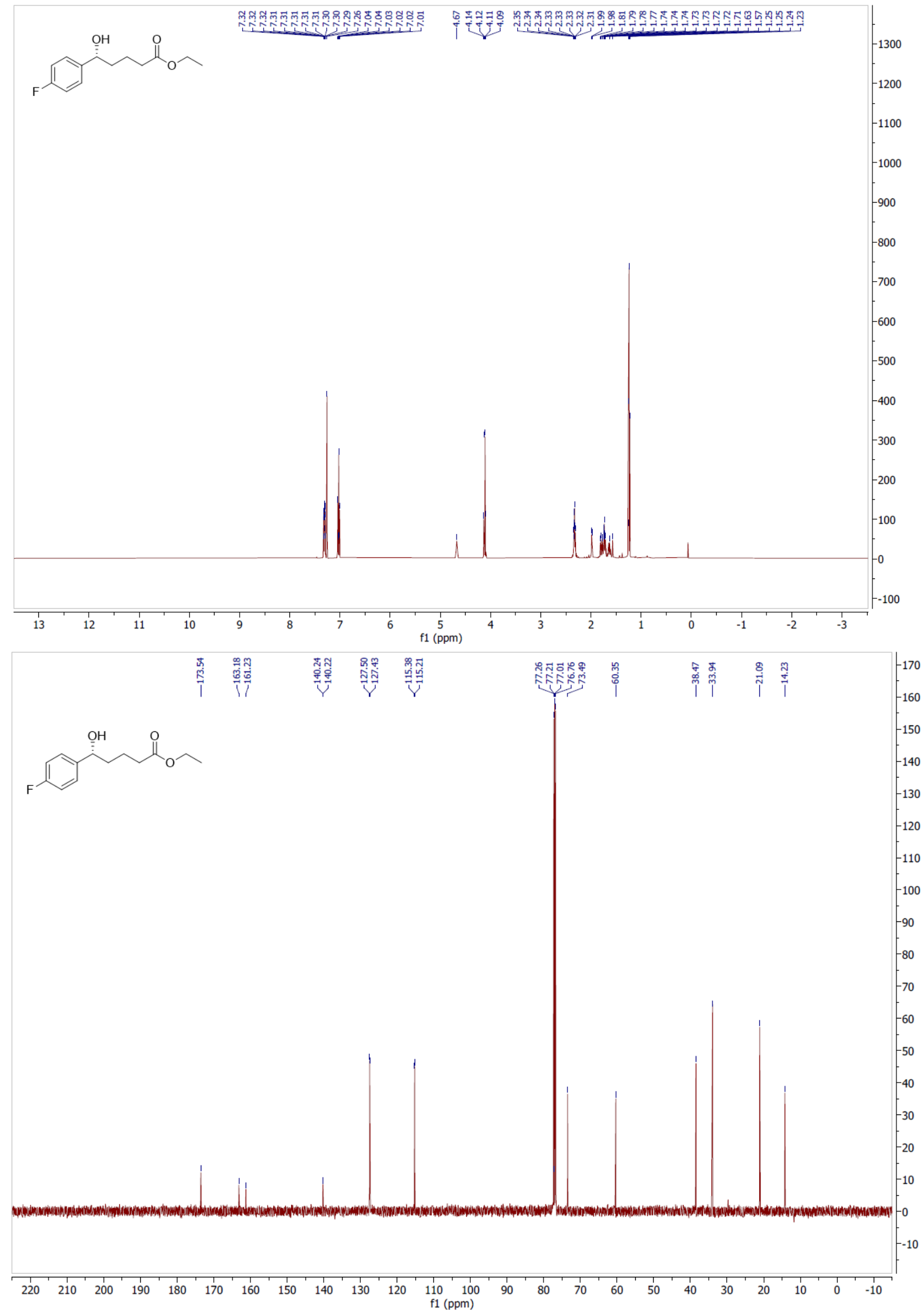


\section{4b}

$\overbrace{\mathrm{CF}_{3}}^{\mathrm{H}}(R)$
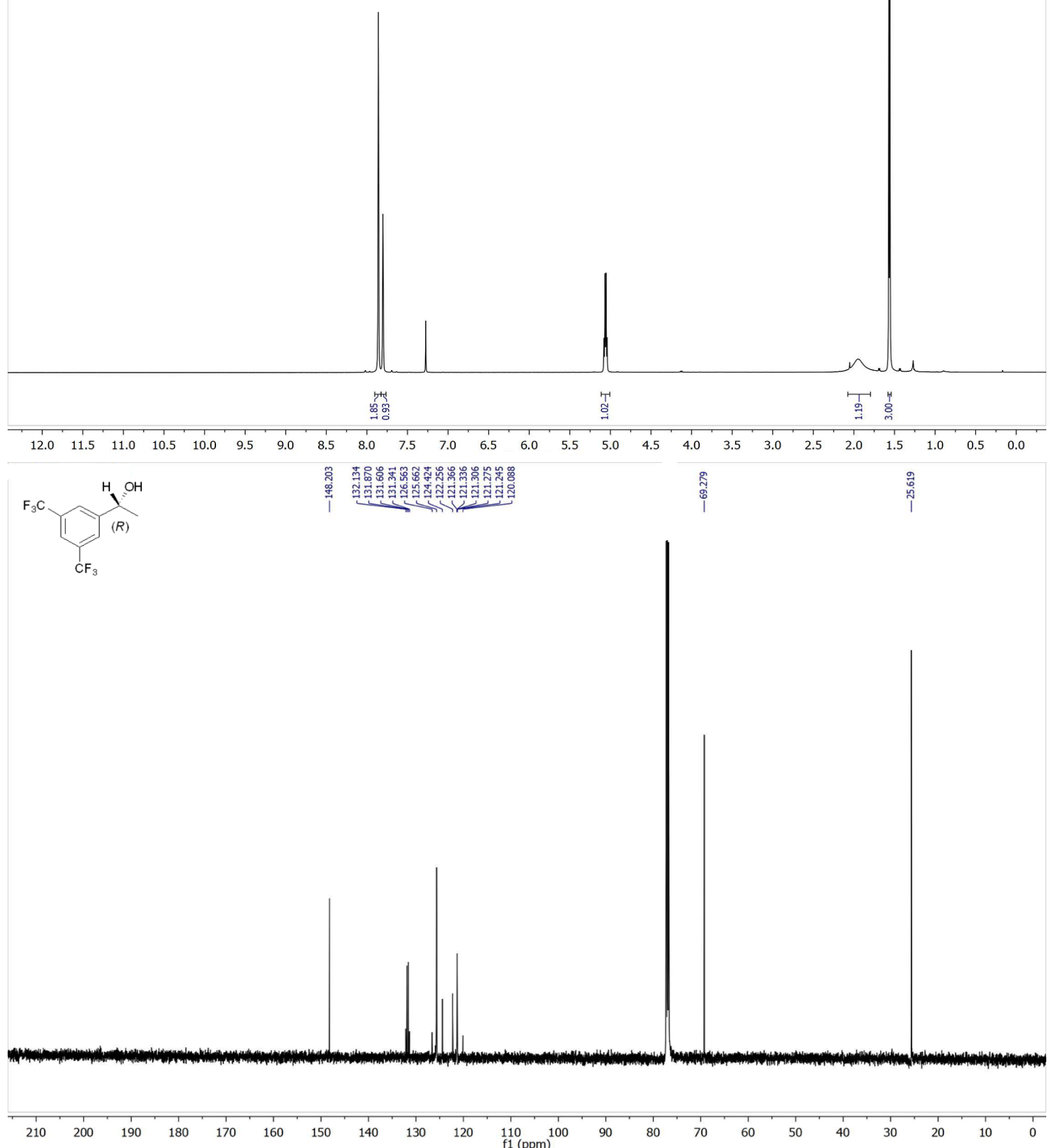